\author{
UNIVERSIDADE DE SÃO PAULO \\ ESCOLA DE ENGENHARIA DE SÃO CARLOS \\ DEPARTAMENTO DE ENGENHARIA HIDRÁULICA E SANEAMENTO
}

CAMILA ABREU BORGES DA SILVA RABELO

OTIMIZAÇÃO DA PRODUÇÃO DE HIDROGÊNIO E ÁCIDOS ORGÂNICOS EM REATOR EM BATELADA A PARTIR DE CONSÓRCIO DE BACTÉRIAS AUTÓCTONES E ALÓCTONES DO BAGAÇO DE CANA-DE-AÇÚCAR

VERSÃO CORRIGIDA

São Carlos

2018 

CAMILA ABREU BORGES DA SILVA RABELO

\section{OTIMIZAÇÃO DA PRODUÇÃO DE HIDROGÊNIO E ÁCIDOS ORGÂNICOS EM REATOR EM BATELADA A PARTIR DE CONSÓRCIO DE BACTÉRIAS AUTÓCTONES E ALÓCTONES DO BAGAÇO DE CANA-DE-AÇÚCAR}

Tese apresentada à Escola de Engenharia de São Carlos da Universidade de São Paulo, como parte dos requisitos para obtenção de título de Doutor em Ciências: Engenharia Hidráulica e Saneamento

Orientadora: Profa. Assoc. Maria Bernadete Amâncio Varesche

VERSÃO CORRIGIDA

São Carlos 
AUTORIZO A REPRODUÇÃO TOTAL OU PARCIAL DESTE TRABALHO, POR QUALQUER MEIO CONVENCIONAL OU ELETRÔNICO, PARA FINS DE ESTUDO E PESQUISA, DESDE QUE CITADA A FONTE.

Ficha catalográfica elaborada pela Biblioteca Prof. Dr. Sérgio Rodrigues Fontes e Seção Técnica de Informática, EESC/USP com os dados fornecidos pelo(a) autor(a).

Rabelo, Camila Abreu Borges da Silva

R1140 Otimização da produção de hidrogênio écicios orgânicos em reator em batelada a partir de consórcio de bactérias autóctones e alóctones do bagaço de cana-de-açúcar / Camila Abreu Borges da Silva Rabelo; orientadora Maria Bernadete Amâncio Varesche. São Carlos, 2018.

Tese (Doutorado) - Programa de Pós-Graduação em Engenharia Hidráulica e Saneamento e Área de Concentração em Hidráulica e Saneamento -- Escola de Engenharia de São Carlos da Universidade de São Paulo, 2018 .

1. Biomassa lignocelulósica. 2. Ácido butírico. 3. Ácido succínico. 4. Bacteroides. 5. Concentração de substrato. 6. Metodologia de superficie de resposta. 7. pH. I. Título.

Bibliotecário responsável pela estrutura de catalogação da publicação:

Eduardo Graziosi Silva - CRB - 8/8907 


\section{FOLHA DE JULGAMENTO}

Candidata: Bacharel CAMILA ABREU BORGES DA SILVA RABELO.

Título da tese: "Otimização da produção de hidrogênio e ácidos orgânicos em reator em batelada a partir de consórcio de bactérias autóctones e alóctones do bagaço de cana-de-açúcar".

Data da defesa: 09/02/2018.

\section{Comissão Julgadora:}

Resultado:

Profa. Associada Maria Bernadete Amâncio Varesche Silva (Orientadora)

(Escola de Engenharia de São Carlos/EESC)

Prof. Titular Marcelo Zaiat

(Escola de Engenharia de São Carlos/EESC)

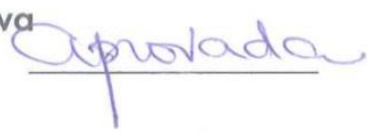

Profa. Dra. Simone Damasceno Gomes

(Universidade Estadual do Oeste do Paraná/UNIOESTE)

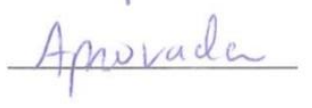

Profa. Dra. Claudia Etchebehere Arenas

(Instituto de Investigaciones Biológicas Clemente Estable)

Prof. Dr. Rogers Ribeiro

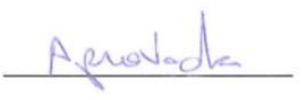

(Faculdade de Zootecnia e Engenharia de Alimentos/FZEA-USP)

Coordenador do Programa de Pós-Graduação em Engenharia Hidráulica e Saneamento:

Prof. Dr. Eduardo Mario Mendiondo

Presidente da Comissão de Pós-Graduação:

Prof. Associado Luis Fernando Costa Alberto 

Aos meus pais Domingos e Carmélia, ao meu irmão Felipe Aos meus filhos Maria Clara, Samuel e Bernardo Ao meu Marcim

Com amor, Dedico 



\section{AGRADECIMENTOS}

A Deus, pela vida.

Aos meus pais, pelo amor com que me orientaram, pela educação, pelas oportunidades oferecidas, pela presença tão marcante no meu dia-a-dia. Ao meu irmão pelo carinho, companheirismo. À Tia Nanci e Naná pelo apoio e pela torcida. À Waldomira, Néia, Vando e Mari por todo carinho e apoio. À minha vó Juraci (in memoriam) pelos seus ensinamentos e exemplos.

Aos meus filhos, o colorido da minha vida, o equilíbrio do meu ser, obrigada! Ao Marcim, pelo companheirismo e amor com que vem caminhando ao meu lado, obrigada pelo apoio e compreensão, obrigada por fazer parte da minha vida!

À professora Maria Bernadete por ter aceitado ser minha orientadora, contribuindo para o meu desenvolvimento profissional e pessoal. Sou muito grata a você. Muito obrigada!

Às técnicas do LPB, à Janja, Isabel, Helô e Carol, pela ajuda tão capacitada e eficiente nas mais diferentes atividades. À Silvana, à técnica da graduação Juliana e ao técnico de informática Fernando. Aos professores do LPB, Eugênio Foresti, Marcelo Zaiat, Márcia Damianovic e Wiclef. Ao professor da UFSCar, Tininho. Muito obrigada pela disposição e ajuda durante o meu doutorado!

Aos colegas do LPB, pelas discussões e ajudas frequentes e pela adorável convivência! Em especial obrigada à Carla, Carol, Cebola, Laís, Lívia e Rachel que ultrapassaram a fronteira do profissional e marcaram a minha vida pessoal também!

Às minhas amigas Renata, Rosane e Carol pelo apoio (mesmo de tão longe...).

À Universidade de São Paulo, à Escola de Engenharia de São Carlos e ao Departamento de Hidráulica e Saneamento. Ao Conselho Nacional de Desenvolvimento Científico e tecnológico (CNPq) pela bolsa concedida. À Fundação de Amparo à Pesquisa do Estado de São Paulo (FAPESP) pelo auxílio financeiro.

\section{Muito obrigada!!}





\section{RESUMO}

\section{Rabelo, C.A.B.S. Otimização da produção de hidrogênio e ácidos orgânicos em reator em}

batelada a partir de consórcio de bactérias autóctones e alóctones do bagaço de cana-deaçúcar. 154 p. Tese (Doutorado) - Escola de Engenharia de São Carlos, Universidade de São Paulo, São Carlos, 2018.

Nessa pesquisa avaliou-se a produção fermentativa de hidrogênio e ácidos orgânicos a partir do bagaço de cana-de-açúcar (BCA) usado como substrato em reatores em batelada. Três condições de pré-tratamento (hidrotérmico, autoclave e hidrotérmico mais autoclave) do BCA e condição in natura foram avaliadas a fim de favorecer a produção de hidrogênio. Verificouse produção molar de hidrogênio de 3,79 mmol/L, 3,47 mmol/L, 1,67 mmol/L e 1,01 mmol/L para BCA autoclavado, BCA in natura, BCA pré-tratado em sistema hidrotérmico e BCA pré-tratado em sistema hidrotérmico seguido de autoclave, respectivamente. A partir desses valores, optou-se por usar o BCA autoclavado como substrato para otimização da produção de hidrogênio e ácidos orgânicos a partir de metodologias de delineamento do composto central e superfície de resposta. Foram monitorados 10 reatores em batelada (R1 a R10), em triplicatas, com diferentes concentrações de substrato $(0,8$ a $9,2 \mathrm{~g} / \mathrm{L})$ e $\mathrm{pH}(\mathrm{de} 4,6$ a 7,4$)$. A maior produção de hidrogênio $(24,1 \mathrm{mmol} / \mathrm{L})$ e $6,4 \mathrm{~g} / \mathrm{L}$ de ácidos orgânicos foram obtidos em $\mathrm{R} 4$ $(8,0 \mathrm{~g} \mathrm{BCA} / \mathrm{L} \mathrm{e} \mathrm{pH} 7,0)$. Os açúcares glicose, arabinose, xilose, manose e galactose foram observados ao longo do tempo de operação em todos os reatores, sendo arabinose observado em maior concentração nas condições dos reatores R3 $(8,0$ g BCA/L e pH 5,0) e R8 $(5,0 \mathrm{~g}$ BCA/L e pH 7,4), respectivamente, $1.415,3$ e 1.372,5 mg/L. A produção de hidrogênio foi concomitante à formação de ácidos orgânicos, principalmente butírico (de 14,6 a 33,8\% em R1 e R6, respectivamente) e succínico (de 19,5 a 26,4\% em R3 e R9, respectivamente). Os dois fatores analisados, concentração de substrato e $\mathrm{pH}$, exerceram efeitos significativos na produção de hidrogênio, ácido butírico e succínico. A partir dos resultados obtidos com o planejamento fatorial, foi possível verificar que o valor máximo de produção de hidrogênio estimado pelo modelo foi de $23,10 \mathrm{mmol} / \mathrm{L}$, para 7,0 g BCA/L e pH 7,2. O valor obtido no experimento de otimização (Rotm) foi de 19,84 mmol/L, com grau de precisão do modelo de 85,9\% para produção de hidrogênio a partir de BCA autoclavado. Sequenciamento massivo via plataforma Illumina (Miseq) foi realizado para a identificação de bactérias do reator do ponto central, (R9, 5,0 g BCA/L e pH 6,0), do reator otimizado (Rotm, 7,0 g BCA/L e pH $7,2)$, de amostras do BCA autoclavado e inóculo. No inóculo foram identificadas principalmente bactérias semelhantes a Clostridium bifermentans $(62,69 \%$ de abundância relativa), Bacillus coagulans $(31,67 \%)$ e Enterobacter aerogenes $(2,72 \%)$. No BCA foram identificadas bactérias semelhantes a C. bifermentans $(31,91 \%)$, C. cellobioparum $(32,29 \%)$, C. cellulolyticum (5,69\%), C. sartagoforme (14,63\%) e Paenibacillus spp. (11,67\%). Estas bactérias não foram favorecidas sob as condições impostas em R9 $(5,0 \mathrm{~g} \mathrm{BCA} / \mathrm{L}$ e pH 6,0) e Rotm (7,0 g BCA/L e pH 7,2), uma vez que a abundância relativa das bactérias nas amostras dos reatores foram completamente diferentes. Em R9, bactérias semelhantes a Lactobacillus paracasei e Escherichia hermannii foram as principais identificas com 37,50 e 34,32\% de abundância relativa, respectivamente. Em Rotm, as principais bactérias identificadas foram semelhantes a Bacteroides sp. e Enterobacter aerogenes, com 37,35 e 27,72\% de abundância relativa, respectivamente. Assim, as populações bacterianas, bem como a produção de metabólitos, foram alteradas em função das condições impostas; ou seja, concentração de $\mathrm{BCA}, \mathrm{pH}$ em reatores em batelada com BCA autoclavado como substrato.

Palavras-chave: Biomassa lignocelulósica; Ácido butírico; Ácido succínico; Bacteroides; Concentração de substrato; Metodologia de superfície de resposta; $\mathrm{pH}$. 



\begin{abstract}
Rabelo, C.A.B.S. Optimization of hydrogen and organic acids productions with autochthonous and allochthonous bacteria from sugarcane bagasse in batch reactors. 154 p. Thesis (Doctoral) - Escola de Engenharia de São Carlos, Universidade de São Paulo, São Carlos, 2018.
\end{abstract}

This study evaluated the hydrogen and organic acids fermentative productions from sugarcane bagasse (SCB) as substrate in batch reactors. Three pre-treatment conditions (hydrothermal, autoclave and hydrothermal plus autoclave) of BCA and the in natura condition were evaluated in order to favor the hydrogen production. Hydrogen molar productions of 3.79 $\mathrm{mmol} / \mathrm{L}, 3.47 \mathrm{mmol} / \mathrm{L}, 1.67 \mathrm{mmol} / \mathrm{L}$ and $1.01 \mathrm{mmol} / \mathrm{L}$ was found for SCB pretreated in autoclave, BCA in natura, SCB pretreated in hydrothermal system and SCB pretreated in hydrothermal system followed by autoclaving, respectively. From these values, it was decided to use autoclaved BCA as a substrate for optimization of hydrogen and organic acids productions from the design methodologies of the central compound and response surface. Ten batch reactors ( $\mathrm{R} 1$ to $\mathrm{R} 10)$ were monitored in triplicates with different substrate concentrations ( 0.8 to $9.2 \mathrm{~g} / \mathrm{L})$ and $\mathrm{pH}$ (4.6 to 7.4). The highest production of hydrogen $(24.06$ $\mathrm{mmol} / \mathrm{L})$ and $6.42 \mathrm{~g} / \mathrm{L}$ of organic acids were obtained in $\mathrm{R} 4(8.0 \mathrm{~g} \mathrm{BCA} / \mathrm{L}$ and $\mathrm{pH} 7.0)$. Glucose, arabinose, xylose, mannose and galactose were produced and consumed throughout the operating time of all reactors, and arabinose was observed at higher concentration, 1,415.26 and 1,372.45 mg/L in R3 (8.0 g BCA/L and pH 5.0) and R8 (5.0 g BCA/L and pH 7.4), respectively. The production of hydrogen was concomitant to the formation of organic acids, mainly butyric (from 14.6 to $33.8 \%$ in R1 and R6, respectively) and succinic (from 19.5 to $26.4 \%$ in R3 and R9, respectively). The two factors analyzed, substrate concentration and $\mathrm{pH}$, had significant effects on the production of hydrogen, butyric acid and succinic acid. From the results obtained with the factorial design, it was possible to verify that the maximum value of hydrogen production estimated by the model was $23.10 \mathrm{mmol} / \mathrm{L}$, to $7.0 \mathrm{~g} \mathrm{BCA} \mathrm{L}$ and $\mathrm{pH}$ 7.2. The value obtained in the optimization experiment (Rotm) was $19.84 \mathrm{mmol} / \mathrm{L}$, with an accuracy of $85.9 \%$ for hydrogen production from autoclaved BCA. Sequencing by the Illumina platform (Miseq) was performed for the identification of bacteria from the central point reactor $(\mathrm{R} 9,5.0 \mathrm{~g} \mathrm{BCA} / \mathrm{L}$ and $\mathrm{pH}$ 6.0), optimized reactor (Rotm, $7.0 \mathrm{~g} \mathrm{BCA} / \mathrm{L}$ and $\mathrm{pH}$ 7.2), autoclaved BCA and inoculum samples. In the inoculum were identified mainly bacteria similar to Clostridium bifermentans (62,69\% of relative abundance), Bacillus coagulans $(31,67 \%)$ and Enterobacter aerogenes $(2,72 \%)$. Bacteria similar to C. bifermentans $(31.91 \%)$, C. cellobioparum (32.29\%), C. cellulolyticum (5.69\%), C. sartagoforme (14.63\%) and Paenibacillus spp. (11.67\%). These bacteria were not favored under the conditions imposed on $\mathrm{R} 9$ (5.0 g BCA/L and $\mathrm{pH}$ 6.0) and Rotm (7.0 g BCA/L and $\mathrm{pH} 7.2)$, since the relative abundance of the bacteria in the reactor samples were completely different. In R9, bacteria similar to Lactobacillus paracasei and Escherichia hermannii were the main identified with 37.50 and $34.32 \%$ of relative abundance, respectively. In Rotm, the main bacteria identified were similar to Bacteroides sp. and Enterobacter aerogenes, with 37.35 and $27.72 \%$ relative abundance, respectively. Thus, bacterial populations, as well as the production of metabolites, were altered as a function of the imposed conditions; ie, BCA concentration, $\mathrm{pH}$ in batch reactors with autoclaved BCA as substrate.

Keywords: Lignocellulosic biomass; Butyric acid; Succinic acid; Bacteroides; Substrate concentration; Response surface methodology; $\mathrm{pH}$. 



\section{LISTA DE FIGURAS}

Figura 2.1: Rotas de fermentação mista da glicose (adaptado de Saady, 2013).

Figura 2.2: Fluxograma de obtenção de produtos a partir do BCA e exemplos de utilização dos "blocos de construção".

Figura 2.3: Estrutura da biomassa lignicelulósica (modificado de https://public.ornl.gov/site/gallery).

Figura 2.4: Esquema da hidrólise da celulose (modificado de Koeck et al., 2014)...... 15

Figura 2.5: Bioconversão da hemicelulose (adaptado de Peng et al., 2012) 15

Figura 2.6: Efeito do pré-tratamento na estrutura da biomassa (modificado de https://public.ornl.gov/site/gallery). 16

Figura 2.7: Esquema do modelo de colonização da celulose por C. cellulolyticum (adaptado de Desvaux, 2005). 21

Figura 4.1: Reativação do inóculo fermentativo. 37

Figura 4.2: Fluxograma da avaliação do pré-tratamento do BCA................................. 38

Figura 4.3: Fluxograma dos ensaios do planejamento fatorial. 40

Figura 5.1: Produção de hidrogênio com BCA in natura e pré-tratado como substrato.

Figura 5.2: Ácidos orgânicos nos reatores em batelada dos testes de pré-tratamento: $\mathrm{Rn}$ (reator com BCA in natura), Ra (reator com BCA autoclavado), Rh (reator com BCA prétratado hidrotermicamente) e Rha (reator com BCA pré-tratado hidrotermicamente e autoclavado).

Figura 5.3: Dendograma baseado no coeficiente de similaridade de Pearson a partir do padrão de bandas do DGGE do gene RNAr 16S para o Domínio Bacteria dos reatores de produção de hidrogênio com BCA in natura, pré-tratado em autoclave, pré-tratado em reator hidrotérmico e pré-tratado em reator hidrotérmico seguido de autoclave.

Figura 5.4: Produção de hidrogênio (mmol/L) a partir do BCA em função do tempo nos reatores em batelada do planejamento fatorial: R1 (2,0 g BCA/L e pH 5,0), R2 (2,0 g BCA/L e pH 7,0), R3 (8,0 g BCA/L e pH 5,0), R4 (8,0 g BCA/L e pH 7,0), R5 (0,8 g BCA/L e pH 6,0), R6 (9,2 g BCA/L e pH 6,0), R7 (5,0 g BCA/L e pH 4,6), R8 (5,0 g BCA/L e pH 7,4), R9 e R10 (5,0 g BCA/L e pH 6,0). 
Figura 5.5: Diagramas de Pareto dos efeitos da concentração de substrato e pH na produção máxima de hidrogênio (A), velocidade de produção de hidrogênio (B) e $\lambda$ (C)...... 60

Figura 5.6: Superfície de resposta (A) e Curvas de contorno (B) para produção de hidrogênio $(\mathrm{mmol} / \mathrm{L})$

Figura 5.7: Superfície de resposta (A) e curvas de contorno (B) para velocidade de produção de hidrogênio (mmol/L.d). 64

Figura 5.8: Superfície de resposta (A) e curvas de contorno (B) para $\lambda$ (d). 65

Figura 5.9: DQO solúvel nos reatores do planejamento: R1 (2,0 g BCA/L e pH 5,0), R2 (2,0 g BCA/L e pH 7,0), R3 (8,0 g BCA/L e pH 5,0), R4 (8,0 g BCA/L e pH 7,0), R5 (0,8 g BCA/L e pH 6,0), R6 (9,2 g BCA/L e pH 6,0), R7 (5,0 g BCA/L e pH 4,6), R8 (5,0 g $\mathrm{BCA} / \mathrm{L}$ e pH 7,4), R9 e R10 (5,0 g BCA/L e pH 6,0). 66

Figura 5.10: DQO-equivalente (\%) dos principais metabólitos solúveis produzidos nas amostras finais dos reatores R1 (2,0 g BCA/L e pH 5,0), R2 (2,0 g BCA/L e pH 7,0), R3 (8,0 g BCA/L e pH 5,0), R4 (8,0 g BCA/L e pH 7,0), R5 (0,8 g BCA/L e pH 6,0), R6 (9,2 g BCA/L e pH 6,0), R7 (5,0 g BCA/L e pH 4,6), R8 (5,0 g BCA/L e pH 7,4), R9 e R10 (5,0 g BCA/L e pH 6,0). 66

Figura 5.11: Perfil de açúcares solúveis nos reatores do planejamento fatorial: R1 (2,0 g BCA/L e pH 5,0), R2 (2,0 g BCA/L e pH 7,0), R3 (8,0 g BCA/L e pH 5,0), R4 (8,0 g BCA/L e pH 7,0), R5 (0,8 g BCA/L e pH 6,0), R6 (9,2 g BCA/L e pH 6,0), R7 (5,0 g BCA/L e pH 4,6), R8 (5,0 g BCA/L e pH 7,4), R9 e R10 (5,0 g BCA/L e pH 6,0). 68

Figura 5.12: Ácidos orgânicos dos reatores em batelada do planejamento fatorial: R1 (2,0 g BCA/L e pH 5,0), R2 (2,0 g BCA/L e pH 7,0), R3 (8,0 g BCA/L e pH 5,0), R4 (8,0 g BCA/L e pH 7,0), R5 (0,8 g BCA/L e pH 6,0), R6 (9,2 g BCA/L e pH 6,0), R7 (5,0 g BCA/L e pH 4,6), R8 (5,0 g BCA/L e pH 7,4), R9 e R10 (5,0 g BCA/L e pH 6,0). 71

Figura 5.13: Diagramas de Pareto dos efeitos de concentração de substrato e pH sobre a produção de ácido butírico (A) e succínico (B). 76

Figura 5.14: Superfície de resposta (A) e Curvas de contorno (B) para porcentagem de ácido butírico. 78

Figura 5.15: Superfície de resposta (A) e Curvas de contorno (B) para porcentagem de ácido succínico. 79 
Figura 5.16: Etanol nos reatores do planejamento fatorial: R1 (2,0 g BCA/L e pH 5,0), R2 (2,0 g BCA/L e pH 7,0), R3 (8,0 g BCA/L e pH 5,0), R4 (8,0 g BCA/L e pH 7,0), R5 (0,8 g BCA/L e pH 6,0), R6 (9,2 g BCA/L e pH 6,0), R7 (5,0 g BCA/L e pH 4,6), R8 (5,0 g BCA/L e pH 7,4), R9 e R10 (5,0 g BCA/L e pH 6,0).

Figura 5.17: Diagrama de Pareto com o efeito dos fatores concentração de substrato e pH sobre na remoção de matéria seca. 82

Figura 5.18: Superfície de resposta (A) e curvas de contorno (B) para remoção de matéria seca (MS).

Figura 5.19: Produção de hidrogênio a partir do BCA autoclavado em reator em batelada com as condições otimizadas (Rotm: 7,0 g BCA/L e pH 7,2). 84

Figura 5.20: Perfil de açúcares solúveis nos reator com as condições otimizadas (Rotm: 7,0 g BCA/L e pH 7,2).

Figura 5.21: Ácidos orgânicos do reator otimizado de produção de hidrogênio (Rotm: 7,0 g BCA/L e pH 7,2).

Figura 5.22: Contagem das bactérias anaeróbias viáveis (UFC/mL) ao longo do tempo (d) em $\operatorname{Rotm}(7,0 \mathrm{~g} \mathrm{BCA} / \mathrm{L}$ e pH 7,2)

Figura 5.23: Dendograma baseado no coeficiente se similaridade de Pearson a partir do padrão de bandas do DGGE do gene RNAr 16S para o Domínio Bacteria. Reatores do planejamento: R1 (2,0 g BCA/L e pH 5,0), R2 (2,0 g BCA/L e pH 7,0), R3 (8,0 g BCA/L e pH 5,0), R4 (8,0 g BCA/L e pH 7,0), R5 (0,8 g BCA/L e pH 6,0), R6 (9,2 g BCA/L e pH 6,0), R7 (5,0 g BCA/L e pH 4,6), R8 (5,0 g BCA/L e pH 7,4), R9 e R10 (5,0 g BCA/L e pH 6,0), separadas em dois grupos G1 e G2

Figura 5.24: Dendograma baseado no coeficiente de similaridade de Pearson a partir do padrão de bandas do DGGE do gene RNAr 16S para o Domínio Bacteria. (Rotm: 7,0 g BCA/L e pH 7,2).

Figura 5.25: Índices ecológicos para amostra do inóculo, bagaço de cana-de-açúcar autoclavado (BCA), R9 (5,0 g BCA/L e pH 6,0) e Rotm (7,0 g BCA/L e pH 7,2). 92

Figura 5.26: Abundância relativa $(\%)$ de representantes pertencentes aos filos do Domínio Bacteria da amostra do inóculo, bagaço de cana-de-açúcar autoclavado (BCA) e reatores $\mathrm{R} 9$ (5,0 g BCA/L e pH 6,0) e Rotm (7,0 g BCA/L e pH 7,2). 
Figura 5.27: Coloração de Gram da biomassa do inóculo sob microscopia óptica. .... 96

Figura 5.28: Abundância relativa das espécies bacterianas identificadas no inóculo fermentativo.

Figura 5.29: Abundância relativa das espécies bacterianas identificadas no BCA autoclavado.

Figura 5.30: Diagrama de Venn referente a presença e ausência de espécies bacterianas celulolíticas e/ou fermentativas identificadas do inóculo fermentativo e BCA autoclavado. 99

Figura 5.31: Principais espécies identificadas nas amostras do Inóculo, BCA, R9 (5,0 g BCA/L e pH 6,0) e Rotm (7,0 g BCA/L e pH 7,2). 100

Figura 5.32: Abundância relativa das espécies bacterianas identificadas em R9 (5,0 g BCA/L e pH 6,0). 104

Figura 5.33: Abundância relativa das espécies bacterianas identificadas em $\operatorname{Rotm}(7,0$ $\mathrm{g} \mathrm{BCA} / \mathrm{L}$ e $\mathrm{pH}$ 7,2).

Figura 5.34 Ideograma circular "Circos". Relação de prevalência dos gêneros e espécies mais frequentes nas amostras do inóculo, BCA, R9 (5,0 g BCA/L e pH 6,0) e Rotm (7,0 g BCA/L e pH 7,2), onde o círculo externo representa a abundância relativa em função do número de leituras. 106

Figura 5.35: Rotas de conversão do BCA em açúcares, ácidos orgânicos e hidrogênio. 


\section{LISTA DE TABELAS}

Tabela 2.1: Condições operacionais de produção de hidrogênio .7

Tabela 2.2: Referencias bibliográficas sobre produção de hidrogênio com $C$. bifermentans, B. coagulans ou E. aerogenes como inóculo.

Tabela 2.3: Estudos com a metodologia estatística multivariada para otimização da produção de hidrogênio. 28

Tabela 4.1: Composição do meio de cultura PCS. 36

Tabela 4.2: Planejamento fatorial $2^{2}$ para otimização de concentração de substrato (BCA autoclavado) e $\mathrm{pH}$.

Tabela 4.3: Reações e coeficientes de conversão utilizados para o cálculo da DQO equivalente.

Tabela 4.4: Condições da programação do termociclador para PCR. 46

Tabela 5.1: $P, \mathrm{R}_{\mathrm{m}}$ e $\lambda$ dos reatores de produção de hidrogênio incubados com BCA in natura e em diferentes condições de pré-tratamentos.

Tabela 5.2: Valores das variáveis independentes e variáveis resposta do planejamento fatorial dos reatores em batelada.

Tabela 5.3: Produção de hidrogênio a partir de BCA

Tabela 5.4: Teste ANOVA para os efeitos da concentração de substrato e pH das variáveis de produção, velocidade de produção de hidrogênio e $\lambda$.

Tabela 5.5: Porcentagem dos ácidos orgânico ao final dos experimentos dos reatores em batelada.

Tabela 5.6: Teste ANOVA para os efeitos da concentração de substrato e pH nas variáveis de produção de ácidos butírico e succínico

Tabela 5.7: Matéria seca (MS) e orgânica (MO) nas amostras iniciais e finais dos reatores do planejamento fatorial.

Tabela 5.8: Teste ANOVA para os efeitos da concentração de substrato e pH na remoção de matéria seca (MS).

Tabela 5.9: Resultados do sequenciamento de bactérias das amostras inóculo, BCA, R9 e Rotm. 
Tabela 5.10: Filogenia das bactérias sequenciadas das amostras inóculo, BCA, R9 e Rotm. 94

Tabela 5.11: Taxonomia e fisiologia das espécies bacterianas identificadas no inóculo (A), BCA (B), R9 (C) e Rotm (D) (abundância relativa maior que 0,1\%). 101

Tabela 5.12: Resultados do monitoramento dos reatores do planejamento fatorial... 107 Tabela 5.13 Respostas do planejamento fatorial para concentração de substrato e $\mathrm{pH}$. 109 


\section{LISTA DE ABREVIATURAS E SIGLAS}

BCA Bagaço de cana-de-açúcar

$\mathrm{CaCO}_{3} \quad$ Carbonato de cálcio

CNPq Conselho Nacional de Desenvolvimento Científico e Tecnológico

$\mathrm{CO}_{2} \quad$ Gás carbônico

DCC Delineamento composto central

DGGE Denaturing gradient gel electrophoresis (Eletroforese em gel de gradiente desnaturante)

DNA Ácido desoxirribonucleico

DQO Demanda química de oxigênio

EGSB Reator anaeróbio de leito granular expandido

FAPESP Fundação de amparo a pesquisa do Estado de São Paulo

Fd(red) $\quad$ Ferredoxina reduzida

GC Gas chromatography (Cormatografia gasosa)

$\mathrm{H}_{2} \quad$ Gás hidrogênio

$\mathrm{H}_{2} \mathrm{SO}_{4} \quad$ Ácido sulfúrico

$\mathrm{HCl} \quad$ Ácido clorídrico

HPLC High performance liquid chromatography (Cromatografia líquida de alta eficiência)

q.s.p Quantidade suficiente para

MO Matéria orgânica

MS Matéria seca

MSR Metodologia de superfície resposta

$\mathrm{NaCl} \quad$ Cloreto de sódio

$\mathrm{NaOH} \quad$ Hidróxido de sódio

NCBI National Center for Biotechnology Information 


$\begin{array}{ll}\text { NREL } & \text { National Renewable Energy Laboratory } \\ \text { OMS } & \text { Organização Mundial da Saúde } \\ \text { OTU } & \text { Operation taxonomic units (Unidades taxonômicas operacionais) } \\ \text { p/p } & \text { Peso/peso } \\ \text { p/v } & \text { Peso/volume } \\ \text { pb } & \text { Pares de bases } \\ \text { PCR } & \text { Polymerase chain reaction (Reação de polimerrização em cadeia) } \\ \text { PCS } & \text { Solução peptona-celulose } \\ \text { pH } & \text { Potencial hidrogeniônico } \\ \text { R } & \text { Reator } \\ \text { RCM } & \text { Reinforced clostridial medium } \\ \text { RDP-II } & \text { Ribossomal database project } \\ \text { RNAr } & \text { Universidade de São Paulo } \\ \text { Rotm } & \text { Reido ribonecleico ribossomal com as condições otimizadas } \\ \text { RPM } & \text { Unidade formadora de colônia } \\ \text { UFC } & \text { Roto }\end{array}$




\section{SUMÁRIO \\ 1. INTRODUÇÃO}

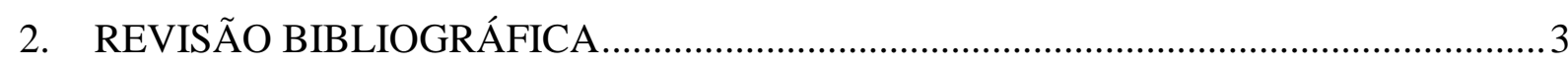

2.1. Produção de hidrogênio e ácidos orgânicos ............................................................... 3

2.2. Bagaço de cana-de-açúcar como substrato para fermentação ............................... 13

2.2.1. Pré-tratamentos aplicados em substratos lignocelulósicos .................................. 16

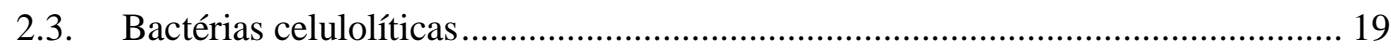

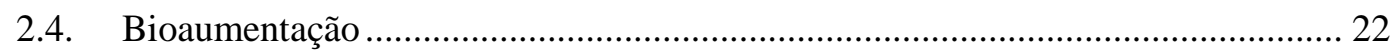

2.4.1. Bioaumento com Clostridium bifermentans, Bacillus coagulas e Enterobacter aerogenes 23

2.5. Planejamento fatorial aplicado à produção de biocombustíveis............................. 27

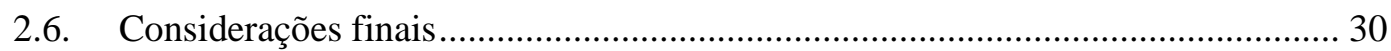

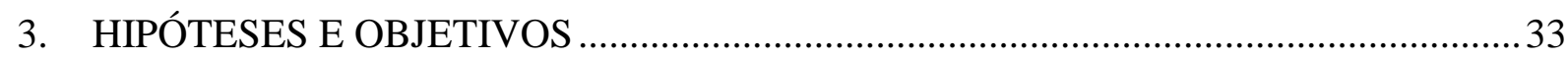

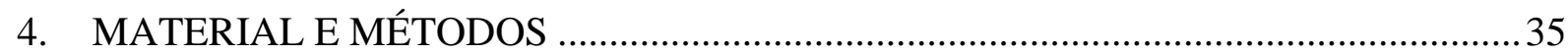

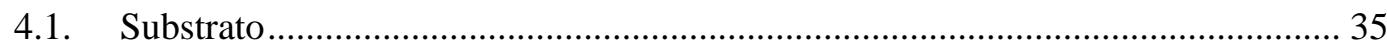

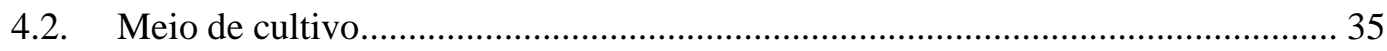

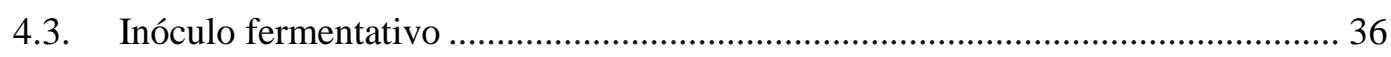

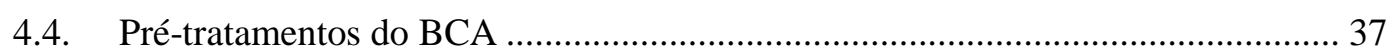

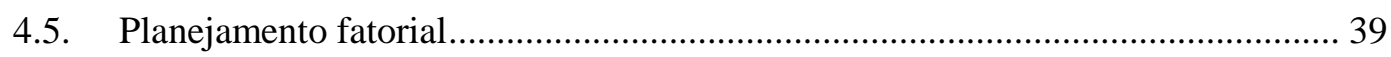

4.6. Análises físico-químicas e cromatográficas ...................................................... 41

4.6.1. Determinação de Carboidratos .......................................................................... 41

4.6.2. Determinação de ácidos orgânicos e álcoois ...................................................... 42

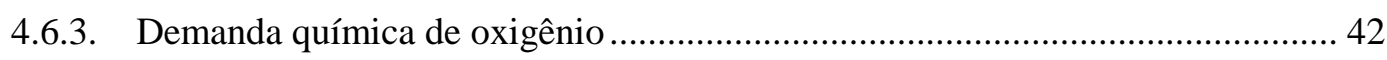

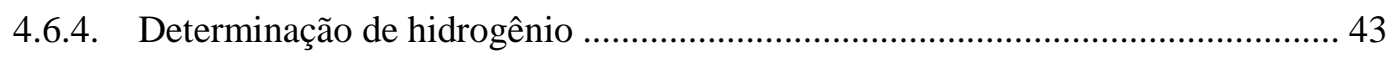

4.7. Ajuste dos dados experimentais de hidrogênio .................................................. 44

4.8. Determinação da matéria seca e matéria orgânica ............................................... 44

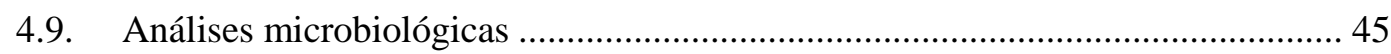

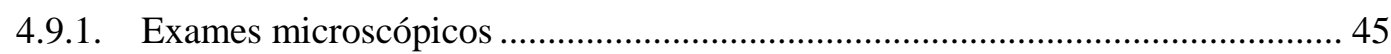

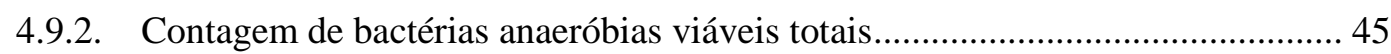

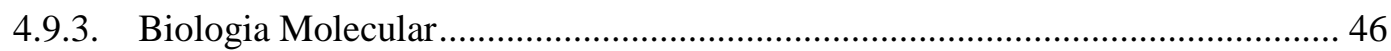

4.9.3.1. Eletroforese em Gel de Gradiente Desnaturante ............................................ 46

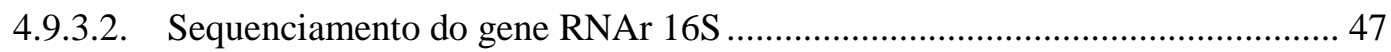

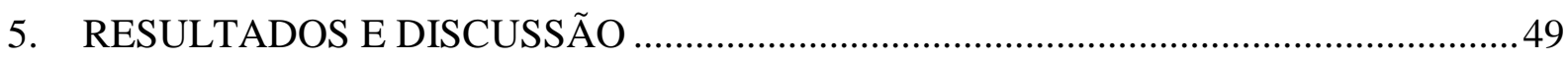

5.1. Efeito do pré-tratamento do BCA na produção de hidrogênio.............................. 49 
5.2. Produção de hidrogênio e ácidos orgânicos a partir de BCA autoclavado

5.3. Análise estatística do Delineamento Fatorial por Composto Central

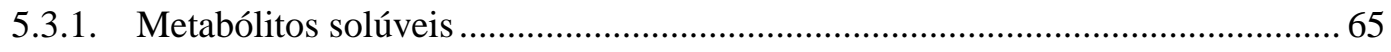

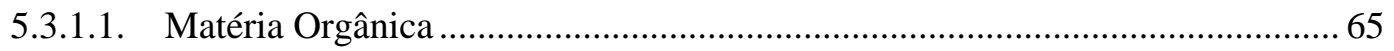

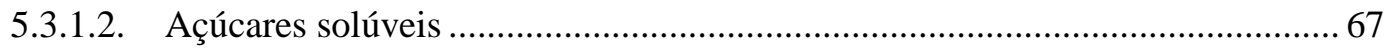

5.3.1.3. Ácidos orgânicos voláteis e álcoois .............................................................. 70

5.3.2. Matéria Seca e Matéria Orgânica ……………..................................................... 80

5.3.3. Validação do modelo de produção de hidrogênio ................................................... 84

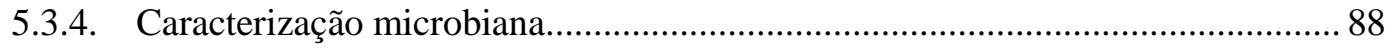

5.3.4.1. Eletroforese em Gel com Gradiente Desnaturante ........................................... 88

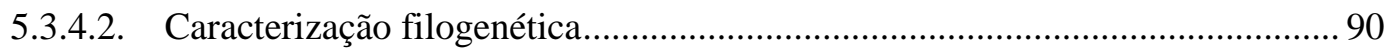

5.3.4.3. Caracterização bacteriana do Inóculo Fermentativo e BCA.............................. 95

5.3.4.4. Caracterização bacteriana de R9 e Rotm .......................................................... 99

5.3.5. Análise comparativa entre os reatores de produção de Hidrogênio..................... 106

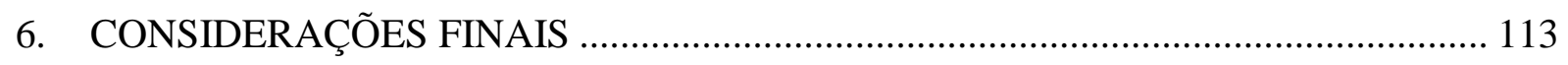

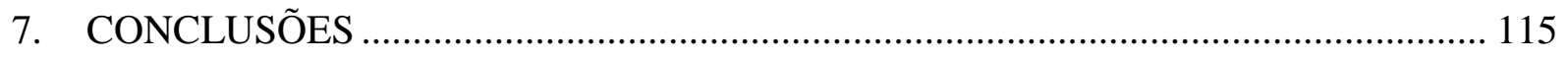

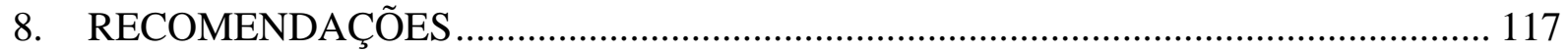

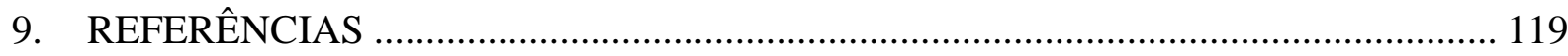




\section{INTRODUÇÃO}

A poluição do ar aumentou consideravelmente nos últimos anos, tornando-se um dos problemas ambientais mais visíveis nas grandes cidades ao redor do globo. De acordo com estatísticas da Organização Mundial de Saúde (OMS), em 2012, 6,5 milhões de mortes, ou seja, 11,6\% de todas as mortes globais foram decorrentes da poluição atmosférica, tornandose o maior risco para a saúde ambiental e humana. Ainda, de acordo com a OMS, as principais fontes de poluição atmosférica são emissão de poluentes pelo uso excessivo de recursos fósseis, transporte, usinas, produção de petróleo e gás (WHO, 2016). Desta forma, diminuir o consumo de combustíveis fósseis e promover o uso de fontes renováveis de energia, como a produção biológica de hidrogênio podem ajudar a reduzir a dependência dos combustíveis fósseis e diminuir as emissões de dióxido de carbono.

O biohidrogênio pode ser produzido por fermentação a partir de substratos orgânicos renováveis. Ampla gama de compostos renováveis tem sido reportada como substrato para produção de hidrogênio, tais como, talos de flores, resíduos sólidos municipais, palha de milho, bagaço de maçã, vinhaça de cana-de-açúcar, papel e bagaço de cana-de-açúcar. O uso destes substratos é uma possibilidade relevante que agrega o tratamento de resíduos à produção de energia; considerada uma alternativa amigável ao ambiente para satisfazer a demanda energética futura. Além disso, alguns substratos orgânicos, como o bagaço de canade-açúcar, são renováveis, economicamente viáveis e amplamente disponíveis em países de clima tropical.

O Brasil é o maior produtor mundial de cana-de-açúcar. A safra 2015/2016 foi de 666,82 milhões de toneladas de cana-de-açúcar e, consequentemente, foram geradas aproximadamente 186 milhões de toneladas de bagaço de cana-de-açúcar (BCA). Em geral, cerca de $50 \%$ do bagaço gerado é queimado como fonte de energia; o excedente é armazenado ou destinado para outros fins como ração para animais, produção de compostos químicos, pasta de papel e etanol (UNICA, 2017). Assim, devido à ampla disponibilidade deste subproduto no Brasil, e à quantidade de BCA excedente, há interesse em desenvolver tecnologias para a produção biológica de compostos de valor-agregado que ofereçam vantagens econômicas, ambientais e estratégicas.

O BCA é um material complexo que contém cerca de $50 \%$ de celulose, $25 \%$ de hemicelulose e $25 \%$ de lignina e, por causa do baixo teor de cinzas, é passível de degradação por culturas microbianas (Pandey et al., 2000). Para bioconversão do BCA, o substrato 
precisa ser hidrolisado e, então, fermentado. Por causa de sua complexa estrutura, torna-se necessário submeter esta biomassa à pré-tratamentos para reduzir a cristalinidade da celulose e aumentar a susceptibilidade do substrato à hidrólise (Galbe e Zacchi, 2012).

A escolha de consórcio microbiano celulolítico e fermentativo também é crucial para a degradação bem sucedida da biomassa lignocelulósica e produção de biocombustíveis. Dentre as bactérias que têm sido relacionadas à bioconversão dos resíduos de biomassa, têm-se destaque para aquelas semelhantes a Clostridium, Bacillus e Enterobacter (He et al., 2013; Lakshmidevi and Muthukumar, 2010; Rafrafi et al., 2013; Ramprakash and Muthukumar, 2014). No mesmo sentido, bactérias autóctones presentes na própria biomassa celulósica podem estabelecer interações microbianas para hidrólise e fermentação simultânea destes substratos.

A produção de metabólitos a partir de biomassa lignocelulósica pode ser grandemente influenciada por muitos fatores, tais como pH e concentração de substrato, além da composição microbiana e das características da própria biomassa, (Jo et al., 2008c). Os efeitos destes fatores, assim como da interação entre eles, podem ser otimizados via metodologia estatística planejamento fatorial, por meio do qual, tem-se a relação entre uma resposta e duas ou mais variáveis experimentais analisadas simultaneamente (Hallenbeck e Ghosh, 2009).

Diante do exposto, o presente estudo centrou-se no processo de bioconversão do BCA em hidrogênio e ácidos orgânicos utilizando cultura autóctone do BCA e alóctone fermentativa composta por Clostridium, Bacillus e Enterobacter. Em seguida, fatores como concentração de substrato e $\mathrm{pH}$ foram avaliados e otimizados por meio de planejamento fatorial para buscar a melhor condição de produção de biocombustíveis a partir do BCA. As comunidades bacterianas autóctone e alóctone e, também, de amostras dos reatores em batelada foram caracterizadas por meio de sequenciamento do gene RNAr 16S visando conhecer e analisar a diversidade da bactérias envolvidas no processo. A análise destes dados pode servir de base para o entendimento da bioconversão do BCA em hidrogênio e ácidos orgânicos. 


\section{REVISÃO BIBLIOGRÁFICA}

\subsection{Produção de hidrogênio e ácidos orgânicos}

A produção biológica de hidrogênio é alternativa sustentável para geração de energia limpa e renovável devido ao esgotamento das reservas de combustíveis fósseis (Hallenbeck e Ghosh, 2009), uma vez que a combustão deste gás não resulta na emissão de gases de efeito estufa (Ren et al., 2016).

De acordo com Hallenbeck (2009), dentre as principais vantagens do biohidrogênio em relação a outros biocombustíveis, destacam-se: (a) $\mathrm{O}$ uso do hidrogênio em células a combustível é mais eficiente do que a combustão necessária para a conversão de outros combustíveis potenciais em energia mecânica; (b) A combustão do hidrogênio não gera poluente; ao contrário do etanol, por exemplo, cujo uso libera acetaldeído, o qual é potencialmente cancerígeno; (c) Todos os biocombustíveis estudados são em grande parte neutros em carbono, uma vez que o carbono liberado pela combustão é derivado, direta ou indiretamente do $\mathrm{CO}_{2}$ atmosférico fixado. No entanto, o carbono emitido associado ao hidrogênio produzido por fermentação bacteriana é liberado durante a sua produção, e não durante a sua utilização, permitindo fácil captura e sequestro do $\mathrm{CO}_{2}$.

Para a produção do biohidrogênio, a fermentação bacteriana tem sido considerada a mais promissora, devido, principalmente, à possibilidade de utilização de materiais orgânicos renováveis como substrato (Wong et al., 2014). Entretanto, a aplicação prática de tecnologias de produção de biohidrogênio em larga escala ainda é limitada a baixos rendimentos, o que requer aprimoramentos na viabilidade do processo a partir do uso de substratos renováveis, seleção/modificação de microrganismos e melhorias no design dos biorreatores (Hallenbeck and Ghosh, 2009; Saini et al., 2015).

A fermentação da matéria orgânica inicia-se com a hidrólise, que é a conversão de polímeros complexos em moléculas de açúcares, como a glicose $\left(\mathrm{C}_{6} \mathrm{H}_{12} \mathrm{O}_{6}\right)$, por exemplo (Bundhoo e Mohee, 2016). Os próximos estágios são acidogênese e acetogênese, culminando com a respiração anaeróbia via metanogênese. Tais metabolismos ocorrem de forma sinérgica e sucessiva por consórcio de microrganismos, de modo que o produto de um passo metabólico se torne o substrato para a próxima reação (Saady, 2013).

A acidogênese inicia-se com a glicólise, sendo a glicose convertida em piruvato (Equação 2.1) (Bundhoo e Mohee, 2016).) 
$\mathrm{C}_{6} \mathrm{H}_{12} \mathrm{O}_{6}+2 \mathrm{NAD}^{+} \rightarrow 2 \mathrm{CH}_{3} \mathrm{COCOO}^{-}+4 \mathrm{H}^{+}+2 \mathrm{NADH}$

Equação 2.1

O piruvato é, então, oxidado em acetil coenzima A (acetil-CoA) por meio de duas rotas possíveis: (1) via formiato-liase ou (2) via ferredoxina reduzida, dependendo da cultura bacteriana empregada. As bactérias entéricas realizam a via formiato-liase, enquanto as anaeróbias estritas realizam a via ferredoxina-reduzida (Hallenbeck e Benemann, 2002; Hallenbeck e Ghosh, 2009).

$\mathrm{Na}$ via formiato liase, a degradação do piruvato pela ação da coenzima $\mathrm{A}(\mathrm{CoA}-\mathrm{H})$ dá origem a acetil-CoA e formiato (Equação 2.2). Sob condições ácidas, o formiato é, então, convertido em $\mathrm{H}_{2}$ (Equação 2.3)

$$
\begin{aligned}
& \mathrm{CH}_{3} \mathrm{COCOO}^{-}+\mathrm{CoA}-\mathrm{H} \rightarrow \text { Acetil-CoA }+\mathrm{HCOO}^{-} \\
& \mathrm{HCOO}^{-}+\mathrm{H}^{+} \rightarrow \mathrm{CO}_{2}+\mathbf{H}_{2}
\end{aligned}
$$

\section{Equação 2.2}

Equação 2.3

$\mathrm{Na}$ via ferredoxina reduzida, o piruvato é oxidado por CoA em acetil-CoA e ferredoxina oxidase $\left(\mathrm{Fd}_{\mathrm{ox}}\right)$ é convertida em ferredoxina redutase $\left(\mathrm{Fd}_{\mathrm{red}}\right)$ e $\mathrm{CO}_{2}$ (Equação 2.4).

$\mathrm{CH}_{3} \mathrm{COCOO}^{-}+\mathrm{CoA}+2 \mathrm{Fd}_{\mathrm{ox}} \rightarrow$ Acetil-CoA $+2 \mathrm{Fd}_{\text {red }}+\mathrm{CO}_{2} \quad$ Equação 2.4

A $\mathrm{Fd}_{\text {red }}$ reduz os íons $\mathrm{H}^{+}$a $\mathrm{H}_{2}$ e é oxidada em $\mathrm{Fd}_{\mathrm{ox}}$ (Equação 2.5).

$$
\mathrm{Fd}_{\mathrm{red}}+2 \mathrm{H}^{+} \rightarrow \mathrm{Fd}_{\mathrm{ox}}+\mathbf{H}_{2}
$$

Equação 2.5

Nas duas vias, formiato liase e ferredoxina, o acetil-CoA gerado dá origem à formação de outros produtos finais, como acetato $\left(\mathrm{CH}_{3} \mathrm{COO}^{-}\right)$e etanol $\left(\mathrm{CH}_{3} \mathrm{CH}_{2} \mathrm{OH}\right)$, por exemplo (Equações 2.6 e 2.7, respectivamente).

$$
\begin{aligned}
& \text { Acetil- } \mathrm{CoA}+\mathrm{H}_{2} \mathrm{O} \rightarrow \mathrm{CH}_{3} \mathrm{COO}^{-}+\mathrm{H}^{+}+\mathrm{CoA}-\mathrm{H} \\
& \text { Acetil-CoA }+2 \mathrm{NADH}+2 \mathrm{H}^{+} \rightarrow \mathrm{CH}_{3} \mathrm{CH}_{2} \mathrm{OH}+\mathrm{CoA}-\mathrm{H}+2 \mathrm{NAD}^{+} \text {Equação } 2.6
\end{aligned}
$$

Qualquer NADH residual formado como subproduto da conversão da glicose em piruvato pode ser reoxidado para produzir $\mathrm{H}_{2}$ (Equação 2.8).

$$
\mathrm{NADH}+\mathrm{H}^{+} \rightarrow \mathrm{NAD}^{+}+\mathbf{H}_{2}
$$

\section{Equação 2.8}

No entanto, em função do produto final, por exemplo, se for ácido butírico ou etanol, nenhum NADH residual estará disponível para conversão em $\mathrm{H}_{2}$. Se o produto final for ácido acético, há residual de NADH, e será convertido em $\mathrm{H}_{2}$ (Bundhoo e Mohee, 2016).

Assim, a produção biológica de hidrogênio via fermentação depende, dentre outros fatores, da rota bioquímica de formação deste produto que é intrínseca às bactérias do inóculo, 
das condições ambientais (pH e pressão parcial do hidrogênio) e do estado de oxidação do substrato (Hallenbeck and Ghosh, 2009).

Ainda, durante a acidogênese, o hidrogênio produzido pode ser reciclado, devido às rotas hidrogenotróficas, por microrganismos que consomem hidrogênio para a formação de ácidos orgânicos ou outros subprodutos. $\mathrm{Na}$ acetogênese ocorre a conversão de ácidos orgânicos em ácido acético e $\mathrm{H}_{2}$ e, finalmente, na metanogênese, o ácido acético e hidrogênio são convertidos em metano (Hallenbeck e Benemann, 2002; Saady, 2013). As rotas metabólicas da fermentação da glicose estão compiladas na Figura 2.1.

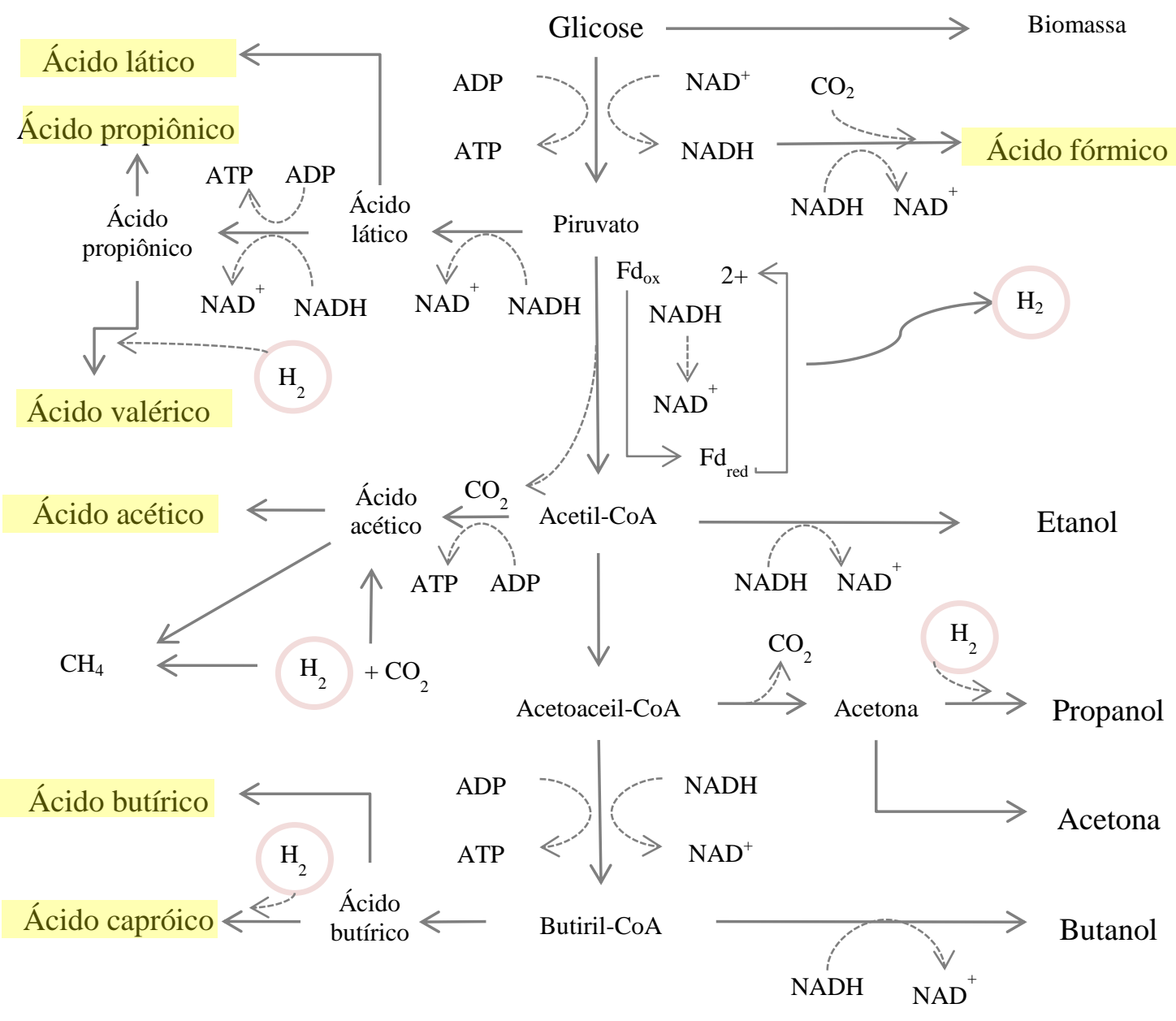

Figura 2.1: Rotas de fermentação mista da glicose (adaptado de Saady, 2013).

$\mathrm{Na}$ fermentação da matéria orgânica por população microbiana mista, o $\mathrm{H}_{2}$ formado é reciclado para formação de ácidos orgânicos, resultando em baixos rendimentos de hidrogênio. Desta forma, torna-se necessária a manipulação e otimização de fatores deste bioprocesso, como tipo e concentração do substrato, microrganismos utilizados, variação de pH e temperatura, para obtenção de maior produção de hidrogênio. 
Pode-se observar na Tabela 2.1, a descrição de algumas pesquisas sobre a otimização de diferentes fatores visando à produção hidrogênio em reatores em batelada.

Fan et al. (2006) e Lin e Hung (2008) elegeram trabalhar com a variação de pH para otimizar a produção de hidrogênio a partir de palha de trigo e celulose como substratos, respectivamente. $\mathrm{O}$ pH 7,0 favoreceu a produção de hidrogênio em ambas as pesquisas com culturas mistas como inóculo. Ren et al. (2010) verificaram que o aumento da concentração de celulose de 5,0 para 10,0 g/L favoreceu a produção de hidrogênio de 284,1 para 429,6 $\mathrm{mmol} / \mathrm{L}$ com celulose como substrato.

Diferentes fatores operacionais, durante a fermentação de farelo de trigo, como tipo e concentração do inóculo, concentração de substrato e pH foram estudados por Pan et al. (2008) a fim de obter maior produção de hidrogênio. O melhor rendimento de produção de hidrogênio obtido foi $128,2 \mathrm{~mL} \mathrm{H_{2 }} / \mathrm{g}$ sólidos voláteis com inóculo oriundo de estação de tratamento de efluentes industriais, concentração do inóculo e substrato de 60,0 e 80,0 g/L, respectivamente, e pH 5,0. A predominância de bactérias semelhantes a Clostridium no inóculo foi significativo para os resultados de Pan et al. (2008) sob as condições otimizadas.

Gadow et al. (2012) avaliaram o efeito da temperatura na produção fermentativa de hidrogênio a partir de celulose $(5,0 \mathrm{~g} / \mathrm{L})$, com cultura mista obtida a partir de lodo de estação de tratamento de esgoto como inóculo e pH 5,7 em reator de tanque-agitado contínuo. Os resultados da fermentação foram 0,6, 15,2 e 19,02 $\mathrm{mmol} \mathrm{H}_{2} / \mathrm{g}$ celulose sob condição mesofílica $\left(37^{\circ} \mathrm{C}\right)$, termofílica $\left(55^{\circ} \mathrm{C}\right)$ e hipertermofílica $\left(80^{\circ} \mathrm{C}\right)$, respectivamente. Os autores observaram nas condições de temperatura termofílica e hipertermofílica, que as arqueias metanogênicas não sobreviveram e as rotas de consumo de hidrogênio não foram favorecidas, resultando em maior produção de hidrogênio. 
Tabela 2.1: Condições operacionais de produção de hidrogênio

\begin{tabular}{|c|c|c|c|c|c|c|}
\hline Inóculo & Substrato & $\mathrm{pH}$ & $\begin{array}{c}\mathrm{T} \\
\left({ }^{\circ} \mathrm{C}\right)\end{array}$ & $\begin{array}{c}\mathrm{H}_{2} \\
(\mathrm{mmol} / \mathrm{L})^{*}\end{array}$ & Principais ácidos orgânicos & Referência \\
\hline $\begin{array}{c}\text { Lodo pré-tratado de } \\
\text { estação de tratamento de } \\
\text { esgoto }\end{array}$ & $\begin{array}{l}\text { Hidrolisado de palha } \\
\text { de milho }\end{array}$ & 5,5 & 35 & 2,84 & Acético e butírico & Datar et al. (2007) \\
\hline \multirow{12}{*}{$\begin{array}{l}\text { Cultura enriquecida de } \\
\text { esterco de gado }\end{array}$} & \multirow{12}{*}{$\begin{array}{l}\text { Celulose } \\
10,0 \mathrm{~g} / \mathrm{L}\end{array}$} & \multirow{3}{*}{5,5} & \multirow{12}{*}{55} & \multirow{3}{*}{0} & Acético (948,6mg/L) & \multirow{12}{*}{ Lin e Hung (2008) } \\
\hline & & & & & Butírico (169,1 mg/L) & \\
\hline & & & & & Propiônico (44,4 mg/L) & \\
\hline & & \multirow{3}{*}{6,5} & & \multirow{3}{*}{19,2} & Acético $(2497,2$ mg/L) & \\
\hline & & & & & Butírico (329,9 mg/L) & \\
\hline & & & & & Propiônico (156,9 mg/L) & \\
\hline & & \multirow{3}{*}{7,0} & & \multirow{3}{*}{32,3} & Acético (3304,7 mg/L) & \\
\hline & & & & & Butírico (177,9 mg/L) & \\
\hline & & & & & Propiônico (316,6 mg/L) & \\
\hline & & \multirow{3}{*}{8,5} & & \multirow{3}{*}{15} & Acético $(2319,6$ mg/L) & \\
\hline & & & & & Butírico (195,6 mg/L) & \\
\hline & & & & & Propiônico (111,9 mg/L) & \\
\hline
\end{tabular}


continuação

\begin{tabular}{|c|c|c|c|c|c|c|}
\hline Inóculo & Substrato & $\mathrm{pH}$ & $\begin{array}{c}\mathrm{T} \\
\left({ }^{\circ} \mathrm{C}\right)\end{array}$ & $\begin{array}{c}\mathrm{H}_{2} \\
(\mathrm{mmol} / \mathrm{L})^{*}\end{array}$ & Principais ácidos orgânicos & Referência \\
\hline & & \multirow{3}{*}{9,0} & & \multirow{3}{*}{0} & Acético $(1083,2 \mathrm{mg} / \mathrm{L})$ & \\
\hline & & & & & Butírico $(121,1 \mathrm{mg} / \mathrm{L})$ & \\
\hline & & & & & Propiônico (66,9mg/L) & \\
\hline $\begin{array}{l}\text { Cultura enriquecida de } \\
\text { solo para hidrólise + } \\
\text { Clostridium sp. para } \\
\text { fermentação }\end{array}$ & $\begin{array}{l}\text { Celulose } \\
(10,0 \mathrm{~g} / \mathrm{L})\end{array}$ & 7,0 & 35 & 1,06 & $* *$ & Lo et al. (2008) \\
\hline \multirow{2}{*}{$\begin{array}{c}\text { Clostridium } \\
\text { acetobutylicum }\end{array}$} & \multirow{4}{*}{$\begin{array}{l}\text { Celulose } \\
(10 \mathrm{~g} / \mathrm{L})\end{array}$} & \multirow{4}{*}{7,0} & \multirow{4}{*}{35} & & Acético $(1700,0 \mathrm{mg} / \mathrm{L})$ & \multirow{4}{*}{ Wang et al. (2008) } \\
\hline & & & & & Butírico (1920,0 mg/L) & \\
\hline C. acetobutylicum + & & & & $* *$ & Acético $(2060,0$ mg/L) & \\
\hline Ethanoigenens harbinense & & & & & Butírico $(987,0$ mg/L) & \\
\hline
\end{tabular}

Continua.. 
continuação

\begin{tabular}{|c|c|c|c|c|c|c|}
\hline Inóculo & Substrato & $\mathrm{pH}$ & $\begin{array}{c}\mathrm{T} \\
\left({ }^{\circ} \mathrm{C}\right)\end{array}$ & $\begin{array}{c}\mathrm{H}_{2} \\
(\mathrm{mmol} / \mathrm{L})^{*}\end{array}$ & Principais ácidos orgânicos & Referência \\
\hline \multirow[b]{2}{*}{$\begin{array}{l}\text { Cultura enriquecida de } \\
\text { esterco de gado }\end{array}$} & $\begin{array}{l}\text { Celulose } \\
(5 \mathrm{~g} / \mathrm{L})\end{array}$ & \multirow[b]{2}{*}{6,8} & \multirow[b]{2}{*}{37} & 284,1 & $* *$ & \multirow[b]{2}{*}{ Ren et al. (2010) } \\
\hline & $\begin{array}{l}\text { Celulose } \\
(10 \mathrm{~g} / \mathrm{L})\end{array}$ & & & 429,6 & $\begin{array}{c}\text { Acético }(1300,0 \text { mg/L) } \\
\text { Butírico }(1200,0 \text { mg/L) } \\
\text { Lático }(300,0 \text { mg/L) }\end{array}$ & \\
\hline $\begin{array}{l}\text { Lodo de estação de } \\
\text { tratamento de esgoto }\end{array}$ & $\begin{array}{l}\text { Celulose } \\
(5,0 \mathrm{~g} / \mathrm{L})\end{array}$ & 5,7 & 55 & $* *$ & $\begin{array}{l}\text { Acético }(138,6 \text { mg/L) } \\
\text { Butírico }(249,1 \mathrm{mg} / \mathrm{L}) \\
\text { Valérico }(42,9 \mathrm{mg} / \mathrm{L}) \\
\text { Acético }(177,0 \mathrm{mg} / \mathrm{L}) \\
\text { Butírico }(107,6 \mathrm{mg} / \mathrm{L}) \\
\text { Propiônico }(13,8 \mathrm{mg} / \mathrm{L})\end{array}$ & Gadow et al. (2012) \\
\hline
\end{tabular}

Continua... 
continuação

\begin{tabular}{|c|c|c|c|c|c|c|}
\hline Inóculo & Substrato & $\mathrm{pH}$ & $\begin{array}{c}\mathrm{T} \\
\left({ }^{\circ} \mathrm{C}\right)\end{array}$ & $\begin{array}{c}\mathrm{H}_{2} \\
(\mathrm{mmol} / \mathrm{L})^{*}\end{array}$ & Principais ácidos orgânicos & Referência \\
\hline & & & & & Acético $(212,4$ mg/L) & \\
\hline & & & 80 & & Butírico $(121,5 \mathrm{mg} / \mathrm{L})$ & \\
\hline & & & & & Propiônico (20,1mg/L) & \\
\hline \multirow{6}{*}{$\begin{array}{l}\text { Cultura pré-tratada de } \\
\text { esterco de elefante }\end{array}$} & & & & & Acético $(93,1 \mathrm{mg} / \mathrm{L})$ & \multirow{6}{*}{$\begin{array}{c}\text { Saripan e Reungsang } \\
\text { (2014) }\end{array}$} \\
\hline & Celulose & 7,0 & 55 & 36,0 & Butírico $(2,7 \mathrm{mg} / \mathrm{L})$ & \\
\hline & \multirow{4}{*}{$\begin{array}{l}\text { Hidrolisado de BCA } \\
\qquad(0,40 \mathrm{~g} / \mathrm{L})\end{array}$} & \multirow{4}{*}{7,0} & \multirow{4}{*}{55} & \multirow{4}{*}{56,8} & Propiônico (14,1mg/L) & \\
\hline & & & & & Acético $(* *)$ & \\
\hline & & & & & Butírico $(* *)$ & \\
\hline & & & & & Lático $(* *)$ & \\
\hline
\end{tabular}

*Produção de $\mathrm{H}_{2}$ calculada em mmol/L

**Produção de ácidos orgânicos não relatada 
Neste sentido, a avaliação de fatores visando otimizar a produção de hidrogênio é necessária para a conversão de diferentes substratos. Esta avaliação é intrínseca às condições de cada trabalho, principalmente à população microbiana utilizada como inóculo.

Como visto, a partir da fermentação podem-se obter, além do hidrogênio, outros produtos de valor agregado, como os ácidos orgânicos. A produção fermentativa de ácidos orgânicos é uma abordagem promissora para a obtenção de produtos químicos versáteis, chamados "blocos de construção", a partir de fontes renováveis de carbono. Estes "blocos de construção" são moléculas com múltiplos grupos funcionais que podem ser precursores de substâncias químicas de importância nas indústrias alimentícia, química e farmacêutica (Song e Lee, 2006; Sauer et al., 2008).

A partir deste conceito, os ácidos succínico, isobutírico, propiônico e acético podem ser utilizados como precursor de anidrido maleico (o qual é produzido a partir de petróleo), precursor de fragrâncias, alimentos para animais e solventes, respectivamente (Sauer et al., 2008). Pode-se observar na Figura 2.2 abordagem em cadeia destes principais produtos de valor agregado e seleção de exemplos de utilização dos químicos secundários derivados dos "blocos de construção" (adaptado de Werpy e Petersen, 2004). 


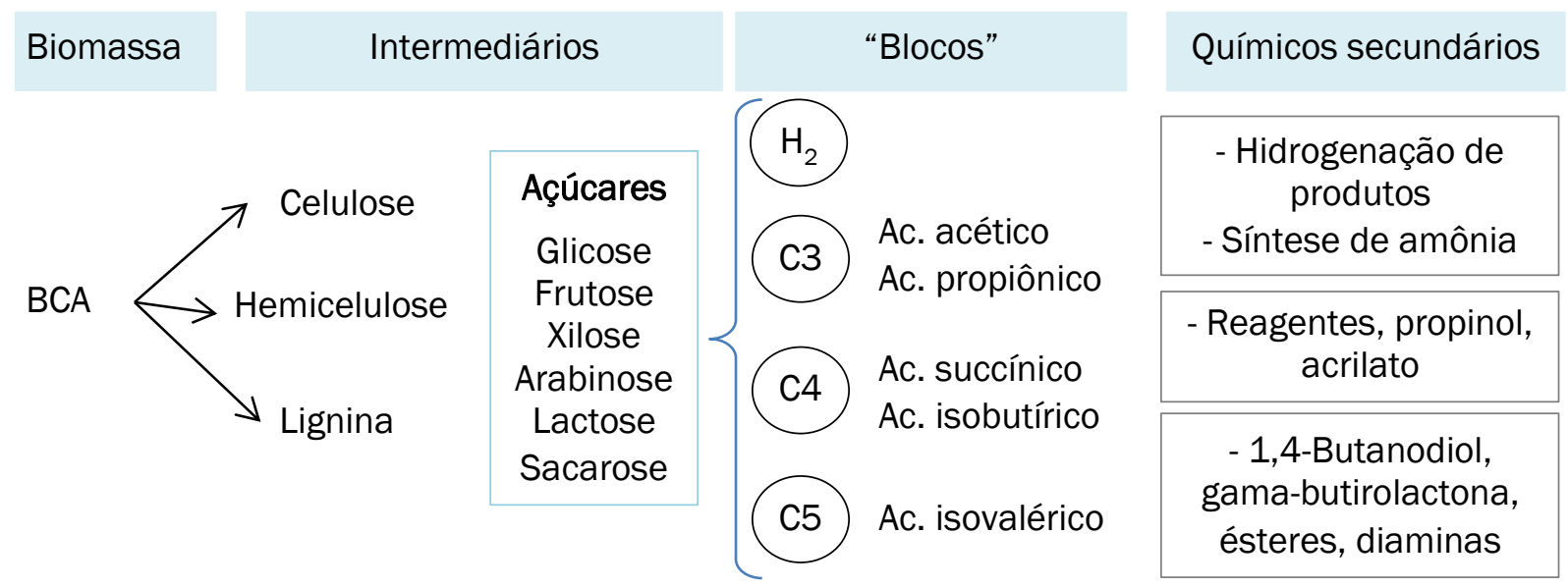

Exemplos de utilização dos químicos secundários

Industrial: Inibidores de corrosão industrial, tratamento de água de caldeiras, lubrificantes

Indústria Têxtil: Tapetes, Fibras, tecidos, estofados, cortinas.

Indústria alimentícia: Embalagens de alimentos, Fertilizantes, garrafas de bebidas, vitaminas.

Industrial: Floculantes, quelantes, detergentes.

Ambiental: Inibidores de corrosão, tratamento de água de caldeira, purificação de gases.

Figura 2.2: Fluxograma de obtenção de produtos a partir do BCA e exemplos de utilização dos "blocos de construção".

A maior parte da produção industrial de ácidos orgânicos é a partir da síntese química. No entanto, uma vez que esses produtos são utilizados em aditivos alimentares, produtos farmacêuticos e conservantes, as "fontes naturais de produção", como os processos fermentativos, estão na alta demanda dos consumidores de produtos a base de ácidos orgânicos (Chen e Nielsen, 2016; Deng et al., 2016; Zhang et al., 2009).

Para a produção de ácidos orgânicos em larga escala por fermentação, as restrições são o custo referente ao substrato e ao processamento deste substrato. Desta forma, por meio do uso de materiais renováveis, como a biomassa lignocelulósica, será possível reduzir o custo da matéria-prima e, consequentemente, o custo total de produção, o que pode tornar o processo de fermentação mais atraente e competitivo em comparação com o processo petroquímico para produção de ácidos orgânicos (Zhang et al., 2009).

Para a viabilidade da produção fermentativa de ácidos orgânicos, sabe-se que a seleção de microrganismos de alto desempenho é extremamente relevante em termos de rendimento, produtividade e tolerância à elevada concentração de ácidos orgânicos (Zhang et al., 2009; 
Chen e Nielsen, 2016; Dionisi e Silva, 2016; Khan et al., 2016;). A seleção de microrganismos com as características citadas pode também favorecer a produção fermentativa de hidrogênio, uma vez que este gás pode ser concomitantemente produzido com os ácidos orgânicos.

\subsection{Bagaço de cana-de-açúcar como substrato para fermentação}

A cana-de-açúcar é uma gramínea da família Poaceae com inflorescência em forma de espiga, crescimento do caule em colmos e folhas com lâminas de sílica. É composta principalmente por água e açúcares que se concentram nos colmos. O bagaço de cana-deaçúcar (BCA) é o subproduto sólido remanescente do processamento da cana-de-açúcar para produção de açúcar ou álcool (UNICA, 2017).

O Brasil é o maior produtor de cana-de-açúcar da indústria sucroalcooleira, sendo que a produção se concentra nas regiões centro-sul e nordeste. De acordo com estimativas recentes, a produção de bagaço de cana-de-açúcar no Brasil tem crescido nos últimos anos. Por exemplo, na safra de cana-de-açúcar de 2015/2016, foram gerados cerca de 186 milhões de toneladas de BCA (UNICA, 2017). Considerando que cerca de 50\% deste BCA é destinado para produção de energia por combustão (Cardona et al., 2010; Rabelo et al., 2011; UNICA, 2017), o remanescente, ainda em consideráveis quantidades, pode ser utilizado para usos alternativos. Desta forma, o uso do BCA como substrato para bioconversão em produtos de valor agregado tem aumentado consideravelmente nas últimas décadas (Cardona et al., 2010; Laser et al., 2002; Rabelo et al., 2017; Soares et al., 2017). A demanda global por hidrogênio está aumentando significativamente, e a utilização deste material como substrato é reconhecida para acompanhar o fornecimento de hidrogênio a custo competitivo no processo em grande escala (Cherubini, 2010).

Os materiais lignocelulósicos, como o BCA, encontram-se na forma de polímeros (celulose e hemicelulose) associados entre si e recobertos por uma macromolécula aromática complexa (lignina), formando a microfibrila celulósica, o principal constituinte da parede celular vegetal (Canilha et al., 2012) (Figura 2.3). A sua composição difere de uma espécie para outra, no entanto, os componentes principais são cerca de 50 a $60 \%$ de carboidratos na forma de celulose e hemicelulose e 20 a 35\% de lignina (Galbe e Zacchi, 2012). Celulose e hemicelulose podem ser fermentadas para formação, por exemplo, de etanol e biogás; a lignina, no entanto, não pode ser fermentada (Lynd, 1996; Pérez et al., 2002). 


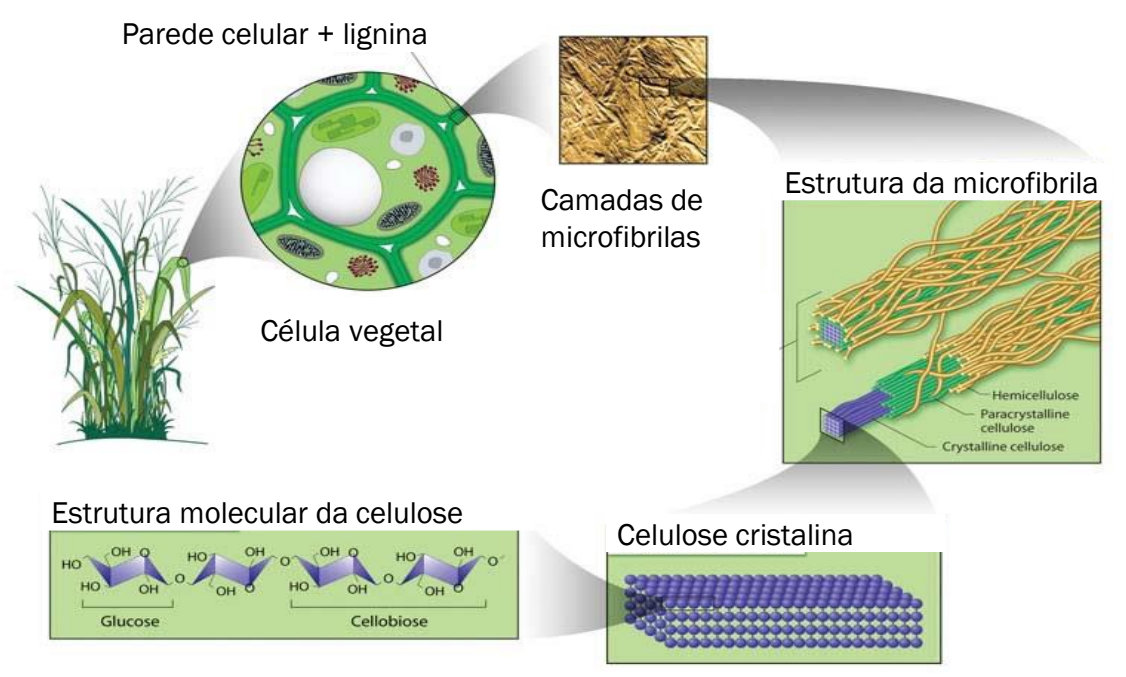

Figura 2.3: Estrutura da biomassa lignicelulósica (modificado de https://public.ornl.gov/site/gallery).

Para a fermentação de materiais lignocelulósicos, a celulose é, inicialmente, degradada em glicose (hidrólise). O mecanismo amplamente aceito para hidrólise enzimática da celulose envolve ações sinérgicas de celulases endoglucanases, exoglucanases e $\beta$-glucosidases, que juntas formam o celulossoma (Zhang e Lynd, 2004; Wilson, 2009).

As etapas do processo de hidrólise ocorrem simultaneamente (Figura 2.4). Primeiro, a hidrólise por endoglucanases e exoglucanases ocorre na superfície do substrato sólido com a liberação de açúcares solúveis para a fase líquida. Esta etapa de despolimerização é o passo limitante para todo o processo de hidrólise da celulose. A hidrólise secundária, que ocorre principalmente na fase líquida, envolve a hidrólise de celobiose em glicose por $\beta$-glucosidases (Percival Zhang et al., 2006). A ação de $\beta$-glucosidases, além de finalizar a despolimerização, também contribui para a taxa global do processo consumindo a celobiose, que é um inibidor de endo e exoglucanases (Olsen et al., 2011). 


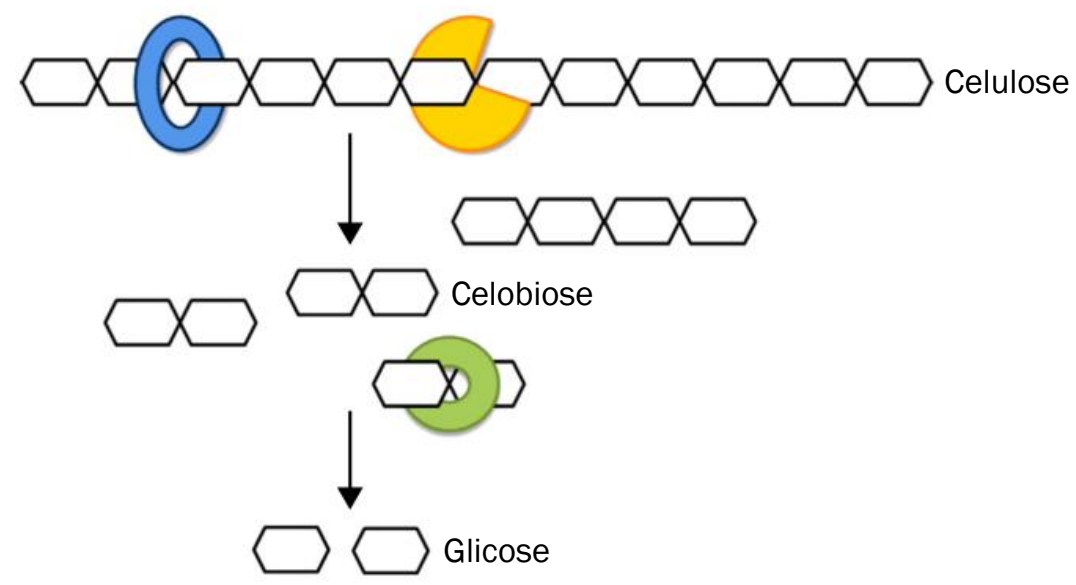

Celulases: (O) Exoglucanase $\bigcirc$ Endoglucanase (O) B-Glucosidase

Figura 2.4: Esquema da hidrólise da celulose (modificado de Koeck et al., 2014).

As hemiceluloses são o segundo polissacarídeos mais abundantes na biomassa, podem ser facilmente hidrolisados em pentoses (xilose e arabinose) e hexoses (glicose, galactose e manose) e, então, transformados em biocombustíveis e outros produtos químicos de valor agregado, como 5-hidroximetilfurfural (HMF), furfural, ácido levulínico e xilitol (Peng et al., 2012; Rasmussen et al., 2014) (Figura 2.5).

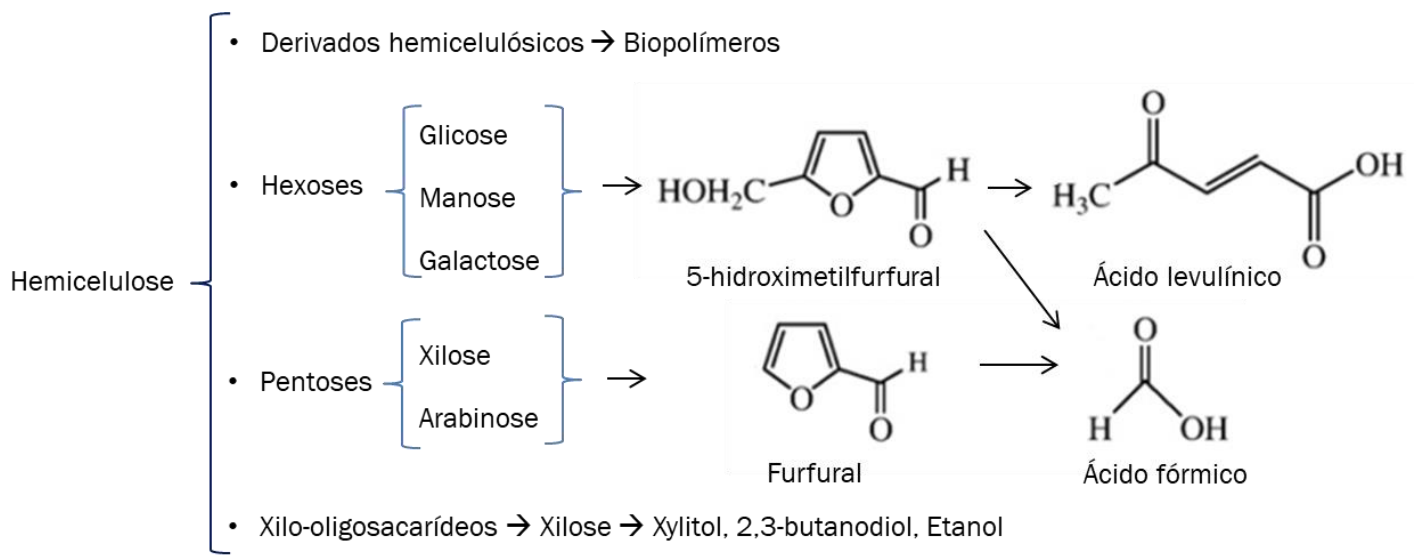

Figura 2.5: Bioconversão da hemicelulose (adaptado de Peng et al., 2012)

A complexidade estrutural da lignina, seu alto peso molecular e sua insolubilidade tornam sua degradação mais difícil do que a biodegradação da celulose e hemicelulose. (Pérez et al., 2002).

Para efetiva produção de biocombustíveis a partir de materiais lignocelulósicos, o sucesso da hidrólise é essencial, certificando a conversão de polissacarídeos em açúcares fermentáveis, os quais podem ser facilmente assimiláveis pelas bactérias fermentativas 
(Saratale et al., 2008). A hidrólise é limitada, em geral, pela estrutura complexa dos materiais, que incluem cristalinidade da celulose, tamanho de partícula e presença de materiais associados, como hemicelulose e lignina (Binod et al., 2011; Galbe e Zacchi, 2012), por esta razão, apenas uma pequena porcentagem de bactérias pode degradar a biomassa celulósica sem pré-tratamento (Wilson, 2011).

\subsubsection{Pré-tratamentos aplicados em substratos lignocelulósicos}

As barreiras físicas e químicas causadas pela estreita associação dos principais componentes da biomassa lignocelulósica dificulta a hidrólise da celulose e hemicelulose em açúcares fermentáveis. Desta forma, pré-tratamentos podem ser aplicados na biomassa para aumentar a acessibilidade da enzima e a digestibilidade da celulose (Laser et al., 2002; Kreuger et al., 2011; Ma et al., 2013) (Figura 2.6).

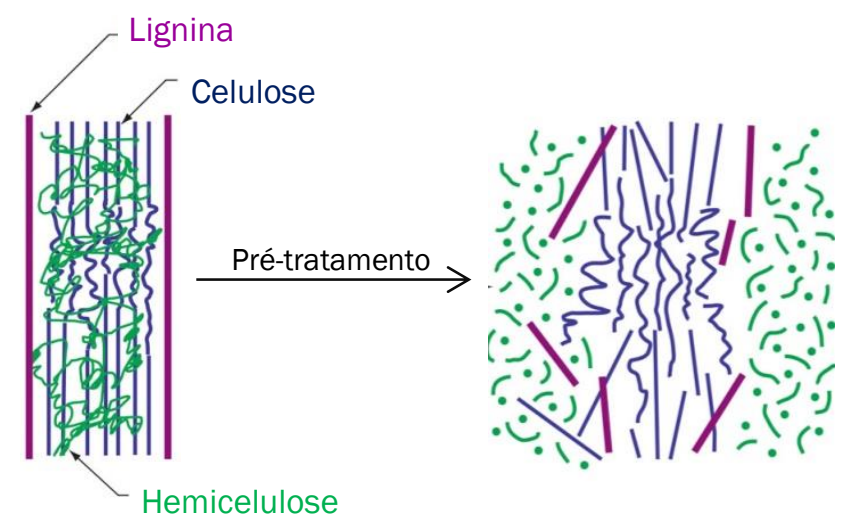

Figura 2.6: Efeito do pré-tratamento na estrutura da biomassa (modificado de https://public.ornl.gov/site/gallery).

Diferentes métodos de pré-tratamentos têm sido descritos e testados, incluindo métodos mecânicos como a redução do tamanho do substrato por meio da moagem; métodos físicos como vapor, radiação, e sonicação; métodos químicos tais como hidrólise ácida e alcalina; métodos biológicos como a degradação microbiana e enzimática; e também a combinação destes métodos (Galbe e Zacchi, 2012; Ren et al., 2016).

$\mathrm{Na}$ escolha do pré-tratamento, é necessário combinar características que permitam posterior uso em escala industrial, incluindo baixo custo de capital, geração mínima de compostos inibidores microbianos e baixo impacto ao meio ambiente (Pan et al. 2008; Cybulska et al. 2010; Lei et al. 2013). 
O pré-tratamento hidrotérmico é um processo aplicado para liberar açúcares a partir de materiais lignocelulósicos. Duas frações são produzidas durante o processo, uma fração sólida, contendo principalmente celulose, e uma fração líquida (hidrolisado) contendo pentoses (xilose e arabinose) e hexose (glicose). Este processo pode ser realizado sem a adição de produtos químicos, tornando-se uma solução potencial para o pré-tratamento de grandes quantidades de substratos lignocelulósicos (Thomsen et al., 2008; Lei et al., 2013).

$\mathrm{Xu}$ et al. (2010) avaliaram cinco diferentes fatores de severidade do pré-tratamento hidrotérmico de silagem de milho $(60 \mathrm{~g} / \mathrm{L})$ como matéria-prima para a produção de bioetanol. Os fatores de severidade avaliados foram os seguintes: $2,98\left(185^{\circ} \mathrm{C} / 3 \mathrm{~min}\right), 3,27\left(195^{\circ} \mathrm{C} / 3\right.$ $\min ), 3,35\left(185^{\circ} \mathrm{C} / 7 \mathrm{~min}\right), 3,64\left(195^{\circ} \mathrm{C} / 7 \mathrm{~min}\right)$ e $3,68\left(185^{\circ} \mathrm{C} / 15 \mathrm{~min}\right)$. O pré-tratamento foi essencial para obtenção de concentração mais elevadas de etanol. Os autores obtiveram 7,67 $\mathrm{g} / \mathrm{L}$ de etanol a partir de silagem de milho sem pré-tratamento. Os valores de etanol obtidos para as condições do pré-tratamento a $195^{\circ} \mathrm{C} / 7$ min foram similares aqueles a $185^{\circ} \mathrm{C} / 15 \mathrm{~min}$; ou seja de 19,92 e 19,98 g/L respectivamente. Após o pré-tratamento, a maior parte da celulose permaneceu no resíduo, que variou entre $85,87 \%$ e $92,90 \%$ para a maior e menor severidade, respectivamente. A maior parte dos açúcares foi observada na fração líquida de $71,64 \%$ (maior severidade) até 78,28\% (menor severidade), e somente 8,05-11,74\% deles foram observados na fração sólida.

Lei et al. (2013) estudaram a influência da temperatura e do tempo de reação do tratamento hidrotérmico de capim herbáceo. Análises de liberação de açúcares foram realizadas para comparar a eficiência do pré-tratamento. Os autores concluíram que altas temperaturas e curto tempo de reação $\left(210^{\circ} \mathrm{C} / 10\right.$ minutos $)$ foram os fatores que melhor promoveram hidrólise do substrato, resultando em 97,96\% de taxa de conversão. Os autores também relataram que a partir do pré-tratamento hidrotérmico a $210^{\circ} \mathrm{C} / 10$ minutos a hemicelulose foi removida mais eficientemente, resultando em baixas concentrações de ácido acético e xilose durante o processo.

No pré-tratamento térmico, o substrato é submetido à temperatura e tempo específicos. Diferentemente do hidrotérmico, no pré-tratamento térmico não há adição de líquidos e, desta forma, a fração sólida do BCA permanece única após o pré-tratamento. A autoclavagem do substrato funciona como um pré-tratamento térmico e foi utilizada por Kim et al. (2003) e Ozkan et al. (2011) para aumentar a digestibilidade do substrato e, consequentemente, aumentar a produção de hidrogênio e metano, respectivamente. 
Destaca-se, portanto, que cada pré-tratamento tem efeito específico sobre as frações de celulose, hemicelulose e lignina, assim, diferentes métodos e condições de pré-tratamento devem ser escolhidos de acordo com a configuração do processo selecionado para os passos subsequentes de hidrólise e fermentação (Alvira et al., 2010). Os pré-tratamentos ácido, enzimático, explosão a vapor e hidrotérmico já foram aplicados no BCA e a produção fermentativa de hidrogênio foi favorável sob após tais condições (Pattra et al., 2008; Lo et al., 2009b; Ratti et al., 2015b; Soares et al., 2017).

Pattra et al. (2008) estudaram o BCA pré-tratado como substrato para produção de hidrogênio em reatores em batelada. O substrato foi submetido ao pré-tratamento ácido utilizando $0,5 \%$ de $\mathrm{H}_{2} \mathrm{SO}_{4}$, a $121^{\circ} \mathrm{C}$ em autoclave por 60 minutos. Sob estas condições, os açúcares liberados foram os seguintes: glicose $(11 \mathrm{~g} / \mathrm{L})$, xilose $(11,29 \mathrm{~g} / \mathrm{L})$ e arabinose $(2,22$ $\mathrm{g} / \mathrm{L})$, além de ácido acético $(2,48 \mathrm{~g} / \mathrm{L})$ e furfural $(0,12 \mathrm{~g} / \mathrm{L})$. A fermentação destes açúcares foi realizada por cultura pura de Clostridium butyricum, em $\mathrm{pH} 5,5$ e $37^{\circ} \mathrm{C}$, e o rendimento de hidrogênio relatado foi $1,73 \mathrm{~mol} \mathrm{H}_{2} / \mathrm{mol}$ de açúcar total. Os autores elegeram trabalhar com bagaço sem casca e com partículas pequenas $(<0,5 \mathrm{~mm})$. $\mathrm{O}$ alto rendimento dos açúcares obtidos a partir da hidrólise ácida pode ser resultante destes critérios de seleção.

O BCA foi utilizado como substrato por Lo et al. (2009b) para produção de hidrogênio. Os autores avaliaram a mudança de temperatura para otimizar, tanto a produção de enzimas, quanto a conversão do substrato em açúcares solúveis. Na estratégia proposta, a produção de enzimas celulolíticas foi realizada por Cellulomonas uda R3-01 a $35^{\circ} \mathrm{C}$, enquanto a hidrólise enzimática da celulose foi a $45^{\circ} \mathrm{C}$. Esta estratégia de aumentar a temperatura para $45^{\circ} \mathrm{C}$ favoreceu ao aumento da concentração de açúcares redutores no meio, uma vez que o crescimento celular foi inibido, evitando o consumo de açúcares. A fermentação foi realizada com a inoculação de Clostridium butyricum CGS5, com resultados de rendimento máximo de $4,79 \mathrm{mmol} \mathrm{H}_{2} / g$ açúcar.

O BCA também foi utilizado como substrato por Ratti et al. (2015), que avaliaram o consórcio microbiano endógeno do próprio bagaço como inóculo hidrolítico e fermentativo. Os autores relataram alto rendimento de hidrogênio (1,2 $\mathrm{mol} \mathrm{H}_{2} / \mathrm{g}$ de substrato) com $0,5 \mathrm{~g}$ de bagaço in natura juntamente com $0,5 \mathrm{~g}$ de bagaço pré-tratado em explosão a vapor. Desta forma, o BCA, além de ser utilizado como substrato, foi também fonte de bactérias capazes de auxiliar na bioconversão do próprio BCA. 
Soares et al. (2017) estudaram a produção de hidrogênio a partir de BCA hidrotermicamente pré-tratado $\left(200^{\circ} \mathrm{C}\right.$ por 10 minutos a 16 bar). Os autores analisaram diferentes concentrações de extrato de levedura como suplemento para crescimento bacteriano e diferentes temperaturas usando metodologia de superfície de resposta para otimização da produção. Máxima produção de hidrogênio (17,7 mmol/L) foi obtida com 2,0 g/L de BCA e $3,0 \mathrm{~g} / \mathrm{L}$ de extrato de levedura à $60^{\circ} \mathrm{C}$.

De acordo com o exposto, pode-se observar que os mecanismos envolvidos no processo de produção de hidrogênio e outros produtos de valor agregado, a partir do BCA, bem como a fisiologia do processo fermentativo ainda não foram completamente esclarecidos, o que é fundamental para melhor compreensão e otimização deste processo. O foco desta área de pesquisa tem sido aperfeiçoar o sistema a partir do aprimoramento de técnicas mais simplificadas, viáveis e econômicas.

\subsection{Bactérias celulolíticas}

Microrganismos produtores de celulases são encontrados em diversos grupos taxonômicos, em sua maioria bactérias e fungos, desempenhando papel importante na biosfera e participação do ciclo do carbono por meio da reciclagem da celulose (Béguin e Lemaire, 1996; Desvaux, 2005).

Em ambientes anaeróbios ricos em biomassa em decomposição, a bioconversão da celulose é realizada por comunidades complexas de microrganismos. Como a celulose é insolúvel, a degradação ocorre extracelularmente e os produtos da hidrólise de celulose ficam disponíveis como fontes de carbono e energia para outros microrganismos que habitam o mesmo ambiente, e essa disponibilidade é a base de muitas interações microbianas. A presença de bactérias não celulolíticas, mas consumidoras de celobiose, favorecem a hidrólise da celulose ao manter as concentrações de celobiose baixas e, assim, prevenir a inibição da celulase por acúmulo de produto (Leschine, 1995).

Um exemplo da interação celulolítica e não-celulolítica foi relatado por Cavedon e Canale-Parola (1992) que analisaram a interação entre uma bactéria celulolítica mesófila (Clostridium sp.) e uma bactéria não-celulolítica (Klebsiella sp.), ambos isolados a partir de ambientes de água doce ricos em matéria vegetal em decomposição. As bactérias foram cocultivadas em meio contendo celulose como fonte de carbono. Os açúcares solúveis liberados pela hidrólise da celulose por Clostridium sp. serviram como substratos fermentáveis para 
Klebsiella sp. Por sua vez, na presença de Klebsiella sp. ocorreu a produção de fatores de crescimento, tais como, biotina e ácido p-aminobenzóico, os quais foram requeridos por Clostridium sp.

Muitas bactérias são capazes de fazer a bioconversão dos substratos lignocelulósicos em unidades de fácil assimilação para seu metabolismo (Wilson, 2011). Entre as bactérias anaeróbias produtoras de celulases, destacam-se: Cellulomonas sp. e Cellulosimicrobium cellulans (Lo et al., 2009a), Bacillus sp. e Clostridium thermocellum (Morrell-Falvey et al., 2015) e Clostridium cellulolyticum (Desvaux, 2005). Cerca de $80 \%$ das bactérias anaeróbias celulolíticas são gram-positivas e pertencentes ao filo Firmicutes e, mais particularmente, classe Clostridia, ordem Clostridiales, sendo a maioria pertencente à família Clostridiaceae, gênero Clostridium.

A formação de endósporos é um dos fatores que favorece a sobrevivência e a ubiquidade de Clostridium em ambientes naturais. Os ambientes anaeróbios são naturalmente ácidos, devido as altas concentrações de produtos da fermentação e, sob estas condições, pode ocorrer a formação de endósporos de Clostridium e Bacillus favorecendo a médio e longo prazo a sobrevivência e competição de tais bactérias com outras espécies não formadoras de estruturas de resistência (Leschine, 1995; Desvaux, 2005).

As bactérias semelhantes a Clostridium já foram identificadas, por meio da clonagem e sequenciamento do gene RNAr 16S, em estudos de conversão de diferentes materiais lignocelulósicos em hidrogênio, como farelo de trigo (Pan et al., 2008), papel sulfite (Botta et al., 2016), celulose microcristalina (Ratti et al., 2013; Rabelo et al., 2014) e bagaço de canade-açúcar (Ratti et al., 2015a; Rabelo et al., 2017).

De maneira geral, bactérias celulolíticas anaeróbias, exemplificadas por $C$. cellulolyticum, são adaptadas a usar fontes de carbono ou outro nutriente em baixa disponibilidade. Em ambientes naturais, a biomassa vegetal, que é usada como substrato por estes microrganismos, é revestida por polímeros, principalmente xilanas e ligninas, que dificultam a acessibilidade à celulose, favorecendo a sobrevivência destas bactérias celulolíticas por limitarem a fonte de carbono (Guedon et al., 1999b; Desvaux, 2005).

C. cellulolyticum é reconhecido e amplamente estudado como modelo de bactérias mesofílicas anaeróbias celulolíticas (Guedon et al., 1999; Desvaux et al., 2000; Desvaux, 2005). Em estudos com estas bactérias e celulose como fonte de carbono foram salientados os seguintes aspectos: 
a) o excesso de açúcares solúveis no meio inibe o crescimento e produção de celulase (Petitdemange et al., 1992);

b) a depleção de nutrientes e baixo valor de $\mathrm{pH}$ inibem o crescimento e produção de celulase (Guedon et al., 1999a);

c) altas concentrações de celulose podem instigar a reorientação do catabolismo celular, (Desvaux et al., 2000);

d) a produção de ácido acético acontece com o crescimento celular, enquanto a produção de ácido lático com a inibição do crescimento celular (Desvaux et al., 2000);

e) o crescimento destas bactérias acontece pelo processo de adesão, colonização, liberação e readesão (Desvaux, 2005) (Figura 2.7).

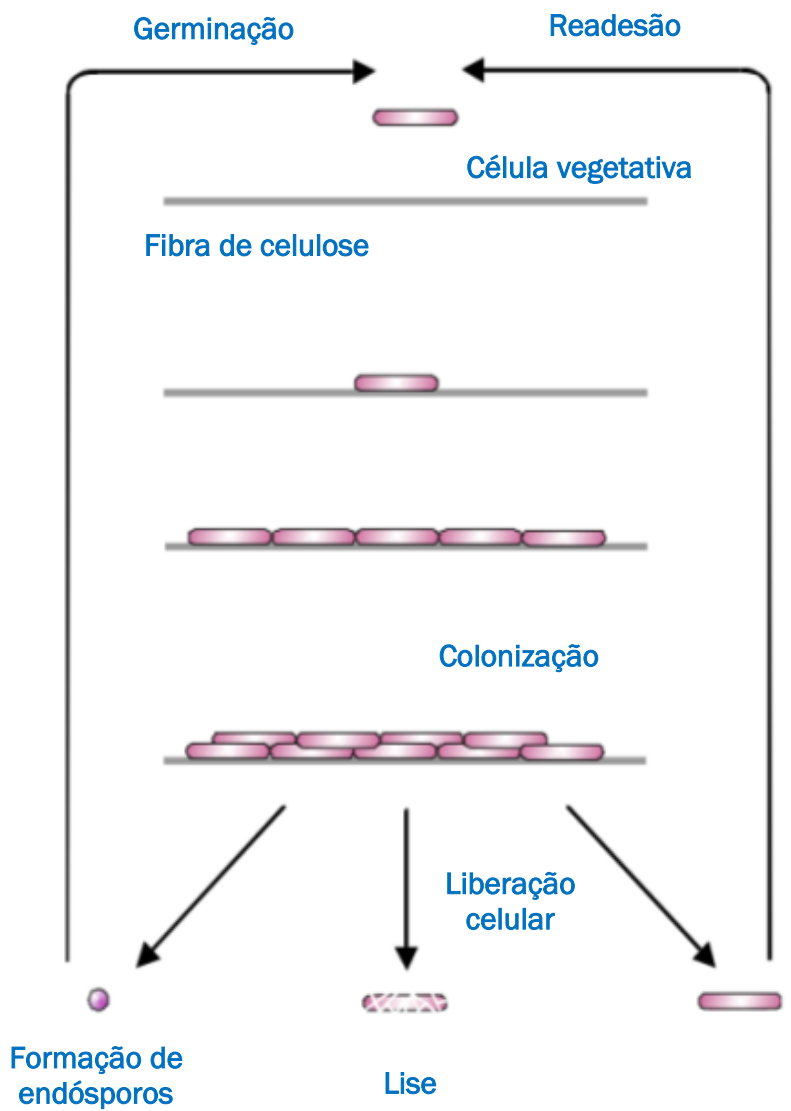

Figura 2.7: Esquema do modelo de colonização da celulose por C. cellulolyticum (adaptado de Desvaux, 2005).

Como visto, as bactérias celulolíticas estão em estreita associação com o substrato a ser degradado. Desta forma, habitats naturais de bactérias celulolíticas, como grama (Petitdemange et al., 1992), solo (Lo et al., 2009a), material em compostagem (Haruta et al., 2002), restos de alimentos (Gomez-Romero et al., 2014) e BCA (Ratti et al., 2015b), possuem 
bactérias celulolíticas aderidas em suas fibras e são passíveis de serem utilizados como fonte de bactérias autóctones para o uso nos processos de hidrólise e fermentação dos mais diversos substratos lignocelulósicos visando a produção de biocombustíveis.

Talia et al. (2012) identificou bactérias celulolíticas autóctones de solo similares a Acidothermus, Micromonospora, Streptomyces, Paenibacillus e Pseudomonas. Segundo os autores, este ecossistema é fonte atraente de bactérias para o estudo de novas enzimas para a degradação da celulose.

No mesmo sentido, Ratti et al. (2015b) identificaram bactérias autóctones do BCA similares a Clostridium e Tepidimicrobia. Além disso, esses autores utilizaram esta fonte de bactérias autóctones como inóculo para a bioconversão de BCA pré-tratado por explosão a vapor em hidrogênio, ácidos acético, láctico e butírico em condição termofílica $\left(55^{\circ} \mathrm{C}\right)$.

\subsection{Bioaumentação}

Sabe-se que a bioaumentação é uma prática empregada no tratamento de efluentes industriais, onde se adiciona microrganismos especializados, ativos e em crescimento para favorecer a biodegradação de efluentes mesmo sob condição de estresse (aumento de carga poluente, presença de compostos tóxicos e outras). É utilizada também em processos de biorremediação de solos contaminados, onde a decomposição do composto poluidor é acelerada pela adição de microrganismos específicos (Kornochalert et al., 2014; Nzila, 2017).

No caso da aplicação da bioaumentação em reatores, tem-se a opção promissora de introduzir microrganismos específicos visando melhorar estágios do processo fermentativo, por exemplo (Ozbayram et al., 2016). Neste caso, abundância e/ou atividade de microrganismos comuns em reatores de biogás pode ser melhorada pela adição de microrganismos relacionados com a hidrólise, acidogênese ou metanogênese (Cater et al., 2015; Tsapekos et al., 2017).

Wang et al. (2008) utilizaram cultura hidrolítica de Clostridium acetobutylicum para produção de hidrogênio a partir de celulose em reatores em batelada. $\mathrm{O}$ bioaumento com bactéria produtora de hidrogênio Ethanoigenens harbinense favoreceu a produção em 77,6\%. Foi observado consumo de açúcares reduzidos por $E$. harbinense, resultando em melhor hidrólise da celulose e melhores taxas de produção de hidrogênio. Cater et al. (2015) estudaram a bioconversão de resíduos de cervejaria por lodo de reator anaeróbio como 
inóculo em reatores em batelada. Os autores avaliaram o efeito da bioaumentação por Ruminococcus flavefaciens, Pseudobutyrivibrio xylanivorans, Fibrobacter succinogenes e Clostridium cellulovorans como culturas puras e misturadas para melhorar a utilização de substrato e aumentar a produção de biogás. Os autores relataram que a partir do bioaumento com $P$. xylanivorans foi obtido maior aumento na produção de metano $(+17,8 \%)$, seguida da co-cultura de $P$.xylanivorans e $F$. succinogenes $(+6,9 \%)$ e da co-cultura de $C$. cellulovorans e $F$. succinogenes $(+4,9 \%)$.

Ozbayram et al. (2016) avaliaram o efeito do bioaumento empregando microbiota de rúmen, principalmente bactérias pertencentes às famílias Ruminococcaceae e Lachnospiraceae, para aumentar a hidrólise de palha de trigo como substrato visando à produção de metano em reatores em batelada. Os autores analisaram as condições controle (sem bioaumento), adição de $2 \%$ e $4 \%$ do número de células. O bioaumento com $4 \%$ de bactérias na suspensão favoreceu a produção de metano em $27 \%$, em relação ao controle. A bioaumentação com culturas enriquecidas de rúmen pode ser estratégia interessante na busca de maior degradação de matéria-prima lignocelulósica em digestores anaeróbios.

A bioaumentação com a bactéria hidrolítica Clostridium thermocellum foi aplicada para melhorar o rendimento de metano em reatores de tanque agitado contínuo alimentados com resíduos agrícolas como substrato e inóculo oriundo de lodo de tratamento de estrume de gado e resíduos da indústria de etanol codigeridos. Com bioaumento, o rendimento de metano aumentou $34 \%$ em relação ao tratamento controle sem adição de $C$. thermocellum (Tsapekos et al., 2017).

\subsubsection{Bioaumento com Clostridium bifermentans, Bacillus coagulas e Enterobacter aerogenes}

O bioaumento com o consórcio de bactérias fermentativas C. bifermentans, $B$. coagulans e E. aerogenes, para produção de hidrogênio a partir de BCA, ainda não consta na literatura e representa um dos principais objetivos do presente estudo. As espécies, separadamente, já foram estudadas para produção fermentativa de hidrogênio em reatores em batelada utilizando diferentes substratos, condições de pH e temperatura (Tabela 2.2). 
Tabela 2.2: Referencias bibliográficas sobre produção de hidrogênio com $C$. bifermentans, $B$. coagulans ou $E$. aerogenes como inóculo.

\begin{tabular}{|c|c|c|c|c|c|}
\hline Bactéria & Substrato & $\mathrm{pH}$ & $\begin{array}{c}\mathrm{T} \\
\left({ }^{\circ} \mathrm{C}\right)\end{array}$ & Produção de $\mathrm{H}_{2}$ & Referência \\
\hline E. aerogenes & Glicose & 4,0 & 38 & $\begin{array}{c}1,0 \mathrm{~mol} \mathrm{H}_{2} / \mathrm{mol} \text { glicose } \\
(55,5 \mathrm{mmol} / \mathrm{L})\end{array}$ & Yokoi et al. (1995) \\
\hline $\begin{array}{l}\text { E. aerogenes }+ \\
\text { C. butyricum }\end{array}$ & Glicose & 5,3 & 37 & $\begin{array}{c}2,4 \mathrm{~mol} \mathrm{H}_{2} / \mathrm{mol} \text { glicose } \\
(*)\end{array}$ & Yokoi et al. (2001) \\
\hline C. bifermentans & $\begin{array}{l}\text { Resíduo de } \\
\text { lodos } \\
\text { ativados pré- } \\
\text { tratado }\end{array}$ & 6,4 & 35 & $\begin{array}{c}0,9 \mathrm{mmol} \mathrm{H}_{2} / \mathrm{g} \text { substrato } \\
(5,34 \mathrm{mmol} / \mathrm{L})\end{array}$ & Wang et al. (2003) \\
\hline B. coagulans & Glicose & 6,5 & 37 & $\begin{array}{c}2,28 \mathrm{~mol} \mathrm{H}_{2} / \mathrm{mol} \text { glucose } \\
(250 \mathrm{mmol} / \mathrm{L})\end{array}$ & Kotay e Das (2007) \\
\hline E. aerogenes & $\begin{array}{c}\text { Efluente pré- } \\
\text { tratado da } \\
\text { indústria de } \\
\text { papel }\end{array}$ & 7,0 & 35 & $\begin{array}{c}2,03 \mathrm{~mol} \mathrm{H}_{2} / \mathrm{mol} \text { açúcar } \\
(520 \mathrm{mmol} / \mathrm{L})\end{array}$ & $\begin{array}{c}\text { Lakshmidevi e } \\
\text { Muthukumar (2010) }\end{array}$ \\
\hline C. bifermentans & Glicose & 7,0 & 35 & $22,3 \mathrm{mmol} / \mathrm{L}$ & Singh et al. (2010) \\
\hline C. bifermentans & Glicose & 6,0 & 37 & $\begin{array}{c}33,2 \mathrm{~mL} \\
(14,8 \mathrm{mmol} / \mathrm{L})\end{array}$ & Zhang et al. (2012) \\
\hline E. aerogenes & $\begin{array}{l}\text { Efluente de } \\
\text { arroz pré- } \\
\text { tratado }\end{array}$ & 7,0 & 33 & $\begin{array}{c}3480 \mathrm{ml} \\
(310 \mathrm{mmol} / \mathrm{L})\end{array}$ & $\begin{array}{c}\text { Ramprakash e } \\
\text { Muthukumar (2014) }\end{array}$ \\
\hline
\end{tabular}

(*) não foi possível calcular a produção de hidrogênio em mmol/L

C. bifermentans são bacilos, gram-positivos, ocorrendo individualmente, em pares ou em cadeias curtas, anaeróbios obrigatórios. A faixa de temperatura ideal para o crescimento destas bactérias é $30-37^{\circ} \mathrm{C}$. Produzem endósporos de resistência ao calor e aos agentes químicos, que são ovais, centrais para subterminais e, geralmente, não incham a célula. Seu nome foi cunhado por causa da característica desta espécie de fermentar tanto carboidratos quanto aminoácidos. Ácido acético e ácido fórmico, e menores quantidades de ácidos isobutírico, isovalérico e isocaproico, são os principais produtos da fermentação, além de abundantes quantidades de hidrogênio (Rainey, 2009). 
Diferentes substratos, sacarose, amido, glicose, frutose e xilose, podem ser utilizados por C. bifermentans para produção fermentativa de hidrogênio (Singh et al., 2010). Os melhores rendimentos de produção de hidrogênio foram relatados em reatores em batelada com glicose como substrato, 22,3 mmol $\mathrm{H}_{2} / \mathrm{L}$ com 10 g glicose $/ \mathrm{L}, 37^{\circ} \mathrm{C}$ e $\mathrm{pH} 6$ (Singh et al., 2010) e $14,8 \mathrm{mmol} \mathrm{H}_{2} / \mathrm{L}$ com $10 \mathrm{~g}$ glicose $/ \mathrm{L}, 35^{\circ} \mathrm{C}$ e $\mathrm{pH} 7$.

C. bifermentans já foi isolado de lodo anaeróbio de tratamento de esgoto (Zhang et al., 2012; Zhang et al., 2015), lodo aeróbio esterilizado em autoclave (Wang et al., 2003) e também a partir de sedimentos de leito de rio (Singh et al., 2010).

Wang et al. (2003) estudaram a bioconversão de resíduo pré-tratado oriundo de lodos ativados do tratamento de esgoto sanitário como substrato em hidrogênio. Os autores consideraram o próprio resíduo como substrato e inóculo para fermentação em reatores em batelada e bioaumentaram com C. bifermentans (10\% v/v). Consideráveis rendimentos de hidrogênio $\left(0,9 \mathrm{mmol} \mathrm{H}_{2} / \mathrm{g}\right.$ substrato) foram obtidos com a adição de C. bifermentans em 24 horas. Entretanto, os microrganismos oriundos do lodo de esgoto converteram o hidrogênio em metano $\left(0,26 \mathrm{mmol} \mathrm{CH}_{4} / \mathrm{g}\right.$ substrato) após 96 horas de fermentação.

B. coagulans são bacilos gram-positivos e anaeróbios facultativos. Produzem endósporos ovais ou esféricos centrais ou terminais em esporângios ligeiramente inchados. São bactérias moderadamente termófilas e acidúricas, o crescimento ocorre entre 30 e $57^{\circ} \mathrm{C}$ e entre $\mathrm{pH}$ 4,0 a 11,0. Podem fermentar galactose, frutose, glicose, glicerol, maltose, manose, e amido com produção de ácidos orgânicos e gás. Podem ser isolados a partir de solo e silagem (Schleifer, 2010).

B. coagulans, isolada a partir de lodos ativados de tratamento de esgoto sanitário digerido anaerobiamente, foi investigado pela sua capacidade de produzir hidrogênio a partir de glicose sob a influência de fatores ambientais diferentes em reatores em batelada. Máxima produção de hidrogênio de $0,25 \mathrm{~mol} / \mathrm{L}$ foi registado para $2 \%(\mathrm{p} / \mathrm{v})$ de glicose em $\mathrm{pH}$ 6,5 e $37^{\circ} \mathrm{C}$ (Kotay e Das, 2007). Os autores relataram que B. coagulans pode ser inibido por excesso de substrato, uma vez que a taxa de crescimento celular e a taxa de produção de hidrogênio diminuíram quando a concentração de glicose foi maior que $2 \%(\mathrm{p} / \mathrm{v})$.

E. aerogenes são bacilos, gram-negativos, anaeróbios facultativos. Glicose é fermentada com a produção de ácidos lático, acético e fórmico e também de hidrogênio. Podem ser isolados a partir de amostras de água, esgoto, solo, produtos lácteos e fezes de seres humanos e animais. Com base em características genotípicas e fenotípicas, E. aerogenes 
é muito mais próximo das espécies de Klebsiella do que de Enterobacter cloacae (espécie típica desse gênero). A transferência de E. aerogenes para o gênero Klebsiella foi proposta, no entanto, uma vez que o nome "Klebsiella aerogenes" tenha sido usado para outro organismo, um novo nome, Klebsiella mobilis, foi aceito (Grimont e Grimont, 2005). Consta na literatura, tanto Enterobacter aerogenes, quanto Klebsiella mobilis referindo à mesma bactéria.

E. aerogenes foi utilizada como inóculo para produção de hidrogênio a partir de glicose com rendimento de 1,0 $\mathrm{mol} \mathrm{H}_{2} / \mathrm{mol}$ glicose (Yokoi et al., 1995). Maiores rendimento de hidrogênio $(2,7 \mathrm{~mol} / \mathrm{mol}$ glicose) foram conseguidos por Yokoi et al. (2001) ao usar o cocultivo de E. aerogenes e $C$. butyricum e amido de batata doce como substrato. E. aerogenes é anaeróbia facultativa, capaz de consumir oxigênio do meio, por conseguinte, favorece o crescimento de bactérias estritamente anaeróbias como Clostridium sp. e, desta forma, pode-se obter produção de hidrogênio.

E. aerogenes foi utilizado como inóculo para fermentação de efluentes de arroz em hidrogênio. A máxima produção relatada foi de $0,31 \mathrm{~mol} \mathrm{H}_{2} / \mathrm{L}$ com o substrato pré-tratado por hidrólise enzimática (Ramprakash e Muthukumar, 2014). Lakshmidevi e Muthukumar (2010) também utilizaram E. aerogenes para fermentação de efluente de indústria de papel e celulose pré-tratados enzimaticamente e relataram bons resultados de produção de hidrogênio em reatores em batelada $(0,52 \mathrm{~mol} / \mathrm{L})$.

Conforme os relatos de produção de hidrogênio, E. aerogenes foi favorecida em condições de substratos pré-tratados (Lakshmidevi e Muthukumar, 2010; Ramprakash e Muthukumar, 2014) e açúcares solúveis disponíveis (Yokoi et al., 2001, 1995; Chu et al., 2011) ou cocultivos com outras bactérias produtoras de hidrogênio (Yokoi et al., 2001).

O cocultivo de C. bifermentans, B. coagulans e E. aerogenes é vantajoso para o processo biotecnológico devido às características fisiológicas das respectivas espécies. As três espécies são produtoras de hidrogênio, com destaque para C. bifermentans (Rainey, 2009). B. coagulans é uma espécie acidúrica, menos sensível ao acúmulo de ácidos orgânicos no sistema (Schleifer, 2010) e, pode desta forma, favorecer a produção de hidrogênio mesmo sob baixo pH. Por fim, E. aerogenes pode favorecer a sobrevivência de $C$. bifermentans e $B$. coagulans, por consumir residual de oxigênio do sistema (Yokoi et al., 1998). 


\subsection{Planejamento fatorial aplicado à produção de biocombustíveis}

O termo "otimização" refere-se a aumentar o desempenho de um sistema, de um processo ou um produto para obter o máximo benefício. Geralmente, a otimização tem sido realizada monitorando a influência de um fator por vez em uma resposta experimental, ou seja, enquanto apenas um fator é alterado, os outros estão a um nível constante. Esta metodologia de otimização é chamada de "uma-variável-por-vez" (one-variable-at-a-time) e não podem explicar os efeitos mútuos entre os fatores estudados. Outra desvantagem da otimização de um fator é o aumento do número de experimentos necessários para a realização da pesquisa, o que contribui para aumentar o tempo e despesas (Araujo e Brereton, 1996; Bezerra et al., 2008; Jo et al., 2008a).

Por outro lado, a otimização usando metodologias estatísticas multivariadas avalia o efeito de interação entre os fatores na resposta e é um método de economia de tempo que requer número reduzido de experimentos para gerar grandes quantidades de informações (Hallenbeck e Ghosh, 2009; Montgomery, 2012).

A metodologia de superfície de resposta (MSR) é uma das mais relevantes metodologias multivariadas. A MSR é baseada no ajuste de uma equação polinomial aos dados experimentais e, por meio dela, tem-se o comportamento de um conjunto de dados com o objetivo de fazer previsões estatísticas. Pode ser bem aplicado quando uma resposta ou um conjunto de respostas de interesse são influenciados por vários fatores. O objetivo é otimizar simultaneamente os níveis desses fatores para obter o melhor desempenho do sistema (Bezerra et al., 2008).

Antes de aplicar a metodologia MSR, primeiro é necessário realizar um planejamento fatorial que defina quais experimentos devem ser realizados na região experimental em estudo. Neste caso, o Delineamento Composto Central (DCC) pode ser usado para as superfícies de resposta quadráticas, adequado para duas ou mais variáveis independentes que podem influenciar o resultado da variável resposta. Os fatores referem-se às variáveis independentes do sistema e, os seus níveis são condições de operação dos fatores, normalmente estudadas em cinco níveis $(-\alpha,-1,0,+1,+\alpha)$ (Bezerra et al., 2008).

O planejamento fatorial é de grande importância para o processo de produção biológica de hidrogênio, pois o processo é complexo e influenciado por muitos fatores (Hallenbeck, 2009; Zhang et al., 2015). 
O planejamento fatorial tem sido utilizado para otimizar os fatores da produção biológica de hidrogênio, incluindo os fatores do processo como concentração de substrato, $\mathrm{pH}$ e temperatura (Jo et al., 2008b; Pan et al., 2008; Skonieczny e Yargeau, 2009; Infantes et al., 2011), concentração de nutrientes (Pan et al., 2008; Soares et al., 2017), concentração de inibidores para organismos consumidores de hidrogênio (Chaganti et al., 2012; Shanmugam et al., 2014) e também os fatores de pré-tratamento do substrato (Lai et al., 2014) (Tabela 2.3).

Tabela 2.3: Estudos com a metodologia estatística multivariada para otimização da produção de hidrogênio.

\begin{tabular}{|c|c|c|c|}
\hline \multirow{2}{*}{ Fatores estudado } & \multicolumn{2}{|c|}{ Resultados } & \multirow{2}{*}{ Referência } \\
\hline & Valores otimizados & $\mathrm{H}_{2}$ & \\
\hline Concentração de glicose & $21,3 \mathrm{~g} / \mathrm{L}$ & & \\
\hline Temperatura & $38^{\circ} \mathrm{C}$ & $\begin{array}{l}425,8 \mathrm{~mL} \mathrm{H}_{2} / \mathrm{g} \\
\text { célula.h }\end{array}$ & Jo et al. (2008) \\
\hline $\mathrm{pH}$ & pH 6,13 & & \\
\hline Concentração de glicose & $23,75 \mathrm{~g} / \mathrm{L}$ de glicose & & \\
\hline Concentração de tampão & 0,159 M de tampão & $185,9 \mathrm{mmol} / \mathrm{L}$ & Pan et al. (2008) \\
\hline Concentração de vitamina & $13,3 \mathrm{~mL} / \mathrm{L}$ de vitamina & & \\
\hline $\mathrm{pH}$ & $\mathrm{pH} 6,1$ & $3,2 \mathrm{mmol}$ & Skonieczny e \\
\hline Concentração de glicose & $3,0 \mathrm{~g} \mathrm{COD} / \mathrm{L}$ & $\mathrm{H}_{2} / \mathrm{L} . \mathrm{h}$ & Yargeau (2009) \\
\hline $\begin{array}{c}\mathrm{pH} \\
\text { Temperatura }\end{array}$ & $\begin{array}{l}\mathrm{pH} 5,4 \\
26^{\circ} \mathrm{C} .\end{array}$ & $51,0 \mathrm{mmol} / \mathrm{L}$ & $\begin{array}{l}\text { Infantes et al. } \\
\qquad(2011)\end{array}$ \\
\hline $\mathrm{pH}$ & pH 6,7 & & \\
\hline Concentração de biomassa & $1900 \mathrm{mg} \mathrm{SSV} / \mathrm{L}$ & $\begin{array}{c}2,64 \mathrm{~mol} \mathrm{H}_{2} / \mathrm{mol} \\
\text { xilose }\end{array}$ & $\begin{array}{c}\text { Chaganti, et al. } \\
\text { (2012) }\end{array}$ \\
\hline e de ácido oleico & 1600 mg/L ácido oleico & & \\
\hline $\begin{array}{c}\text { Fatores da } \\
\text { hidrólise ácida do BCA }\end{array}$ & $\begin{array}{l}2,3 \% \text { de } \mathrm{H}_{2} \mathrm{SO}_{4} \text { durante } \\
114,2 \text { minutos a } 115^{\circ} \mathrm{C} \text {. }\end{array}$ & $\begin{array}{l}\text { 1,86 } \mathrm{mol} \mathrm{H}_{2} / \mathrm{mol} \\
\text { de açúcar total }\end{array}$ & Lai et al. (2014) \\
\hline $\begin{array}{c}\text { Extrato de levedura } \\
\text { Temperatura }\end{array}$ & $\begin{array}{c}3,0 \mathrm{~g} / \mathrm{L} \text { extrato de levedura } \\
60^{\circ} \mathrm{C}\end{array}$ & $17,7 \mathrm{mmol} / \mathrm{L}$ & $\begin{array}{l}\text { Soares et al. } \\
\text { (2017) }\end{array}$ \\
\hline
\end{tabular}

Pan, et al. (2008) avaliaram a otimização dos fatores concentração de glicose, concentração de tampão fosfato e concentração de solução de vitaminas (cobalamina, 
vitamina $\mathrm{C}$, riboflavina, ácido cítrico, piridoxina, ácido fólico e creatina) para a produção de hidrogênio a partir de Clostridium sp. isolado de lodo de efluente de biorreator anaeróbio. As condições ideais reportadas para a produção de hidrogênio foram $23,75 \mathrm{~g} / \mathrm{L}$ de glicose, 0,159 M de tampão de fosfato e 13,3 mL/L de solução de vitamina. Utilizando as condições ótimas obtidas a partir da otimização estatística, os autores observaram aumento da produção de hidrogênio de 100,4 para 185,9 mmol/L.

Shanmugam et al. (2014) investigaram, em reatores em batelada, fatores que minimizassem o consumo de hidrogênio por inóculo oriundo de cultura mista de lodo de tratamento de esgoto sanitário e, consequentemente, aumento da produção de hidrogênio. Os fatores investigados foram temperatura, $\mathrm{pH}$ e concentração de ácido linoléico (inibidor químico de organismos consumidores de hidrogênio). Os autores observaram que a metanogênese foi inibida em reatores com $2 \mathrm{~g} / \mathrm{L}$ de ácido linoléico, $\mathrm{pH}$ 6,0 e $53^{\circ} \mathrm{C}$. E, na condição ótima com $2 \mathrm{~g} / \mathrm{L}$ de ácido linoleico, pH 5,5 e $38^{\circ} \mathrm{C}$, tanto a metanogênese como a homoacetogênese foram inibidas e, desta forma, não foi verificado consumo de hidrogênio.

Lai et al. (2014) estudaram os fatores-chave do pré-tratamento por hidrólise ácida do BCA por meio da metodologia superfície de resposta. O BCA pré-tratado foi utilizado como substrato para produção de hidrogênio com cultura de Thermoanaerobacterium aotearoense em reatores em batelada. A produção de hidrogénio foi maximizada nas condições de 2,3\% de $\mathrm{H}_{2} \mathrm{SO}_{4}$ durante 114,2 minutos a $115^{\circ} \mathrm{C}$. Utilizando estas condições, obteve-se melhor rendimento de hidrogênio de $1,86 \mathrm{~mol} \mathrm{H}_{2} / \mathrm{mol}$ de açúcar total.

Soares et al. (2017), avaliaram os efeitos interativos da concentração de extrato de levedura, como fonte de nitrogênio, e temperatura de incubação na produção de hidrogênio com BCA como substrato em reatores em batelada. Os autores observaram aumento da resposta de produção de hidrogênio de 3,5 para $17,7 \mathrm{mmol} \mathrm{H}_{2} / \mathrm{L}$ com 3,0 g/L de extrato de levedura a $60^{\circ} \mathrm{C}$.

A modelagem e otimização dos fatores que podem afetar a produção de hidrogênio são importantes principalmente em estudos de fermentação de substratos complexos por consórcios microbianos que envolvem múltiplos tipos metabólicos com interações desconhecidas (Hallenbeck e Ghosh, 2009). Este é o caso do presente estudo, cujo objetivo maior foi otimizar a produção de hidrogênio em reatores em batelada a partir da fermentação do BCA por consórcio microbiano autóctone e alóctone. 


\subsection{Considerações finais}

Diante do exposto na revisão de literatura, a produção biológica de hidrogênio é alternativa para o aumento da demanda energética, e a viabilidade do processo está no cerne das discussões mais atuais sobre o assunto. Sendo assim, o uso de subprodutos agroindustriais como substrato agrega uma alternativa para a utilização de resíduos excedentes à produção de energia, tornando a abordagem ainda mais sustentável.

O BCA, proposto como substrato no presente estudo, é um subproduto gerado em grande quantidade no Brasil. Embora, o uso tradicional do BCA seja como substrato para combustão em caldeiras dentro das próprias usinas, há um excedente que pode ser disponibilizado para produção de hidrogênio.

Como destacado nessa revisão, em diversos estudos tem sido considerado o BCA como substrato para produção de hidrogênio, com a busca de possibilidades de torná-lo atrativo e competitivo em relação ao BCA excedente.

No Laboratório de Processos Biológicos (LPB) da Escola de Engenharia de São Carlos (EESC), em particular, a pesquisa da bioconversão do BCA em hidrogênio, metano e outros produtos biotecnológicos tem ganhado destaque no cenário nacional e internacional. O prétratamento desta biomassa por explosão a vapor (Ratti, et al., 2015), reator hidrotérmico (Rabelo, et al., 2017; Soares, et al., 2017), ácido e alcalino (Ahmad, 2017) já foram investigados objetivando a obtenção de melhores rendimentos do produto.

Além disso, diversos inóculos também foram analisados para bioconversão do BCA. Por exemplo, Rabelo et al. (2017) analisaram a utilização de cultura mista oriunda de lodo de estação de tratamento de efluentes industriais. Ahmad (2017) e Soares et al. (2017) utilizaram inóculo oriundo de reator UASB, enquanto, Ratti et al. (2015) utilizaram as bactérias endógenas do BCA para a bioconversão em produtos de interesse biotecnológico.

Outro ponto observado na revisão de literatura foi a dificuldade da hidrólise do BCA. Diversos pré-tratamentos são empregados ao substrato para facilitar a hidrólise enzimática e a liberação de açúcares solúveis para posterior fermentação. Entretanto, os pré-tratamentos podem também destruir as bactérias autóctones presentes em associação com o substrato.

No presente estudo, foi proposto o pré-tratamento térmico em autoclave, em condição menos severa do que o pré-tratamento por explosão a vapor ou hidrotérmico, para favorecer a manutenção de bactérias autóctones hidrolíticas. Além disso, foi escolhido bioaumentar os 
reatores com inóculo fermentativo constituído de bactérias reconhecidamente produtoras de hidrogênio, C. bifermentans, B. coagulans e E. aerogenes.

Ainda, a partir da revisão de literatura, pode-se perceber a importância de técnicas estatísticas multivariadas para avaliar os efeitos mútuos de fatores, bem como as vantagens inerentes a esta metodologia para otimizar a produção biológica de hidrogênio.

Assim, o presente estudo consiste na utilização do BCA como substrato para produção biológica de hidrogênio e ácidos orgânicos e na otimização, por estatística multivariada, de fatores relevantes para qualquer processo biológico, que foram $\mathrm{pH}$ e concentração de substrato. Consiste, ainda, na identificação, por sequenciamento do gene RNAr 16S, das bactérias autóctones do BCA autoclavado que foi utilizado como substrato, das bactérias alóctones do inóculo fermentativo, além das bactérias presentes em amostras de dois reatores do planejamento fatorial, $\mathrm{R} 9$ (reator do ponto central, 5,0 g BCA/L e pH 6,0) e reator com as condições otimizadas (Rotm, 7,0 g BCA/L e pH 7,2).

Os níveis dos fatores foram escolhidos de acordo com a literatura. Uma vez que as condições de $\mathrm{pH}$ pode afetar diretamente a atividade das enzimas produtoras de hidrogênio. Para tanto, os valores escolhidos foram de acordo com a faixa citada para ótima atividade das bactérias do inóculo fermentativo, $C$. bifermentans $(6,5$ a 7,0), B. coagulans $(4,0$ a 7,0) e $E$. aerogenes (6,5 a 7,0) (Grimont e Grimont, 2005; Schleifer, 2010).

Já o fator concentração de substrato, afeta mais a hidrólise do BCA, seja por falta de sítios de ligação enzima-substrato, seja por inibição por excesso de substrato. Desse modo, a faixa de estudo escolhida foi próxima aos valores citados por Desvaux (2005), como ótima concentração de celulose $(6,7 \mathrm{~g} / \mathrm{L})$ para $C$. celulolyticum, bactéria celulolítica mesofílica. Assim os níveis propostos foram os seguintes: $\mathrm{pH} 4,6$ a 7,4 e 0,8 a 9,2 g/L de substrato (BCA).

O presente trabalho vem agregar conhecimentos a cerca da hidrólise e fermentação do BCA, bem como na utilização da metodologia estatística de modelagem e otimização da produção de hidrogênio e ácidos orgânicos a partir de substratos complexos e culturas bioaumentadas. 


\section{HIPÓTESES E OBJETIVOS}

Hipótese 1: As bactérias autóctones do bagaço de cana-de-açúcar podem contribuir com consórcio fermentativo alóctone e favorecer a hidrólise e fermentação do bagaço.

\section{Objetivo:}

Avaliar a produção de hidrogênio e ácidos orgânicos em reatores em batelada com bagaço de cana-de-açúcar como substrato com o favorecimento das bactérias hidrolíticas/fermentativas autóctones e alóctones.

Avaliar a diversidade da comunidade bacteriana autóctone do bagaço de cana-deaçúcar.

Avaliar a diversidade da comunidade bacteriana de reatores em batelada com bagaço de cana-de-açúcar.

Hipótese 2: O pré-tratamento aplicado ao bagaço de cana-de-açúcar pode modificar as populações de bactérias hidrolíticas/fermentativas, bem como favorecer a produção de hidrogênio.

\section{Objetivos:}

Avaliar a produção de hidrogênio em reatores em batelada utilizando bagaço de canade-açúcar submetido a diferentes pré-tratamentos como substrato.

Avaliar a diversidade da comunidade de bactérias dos reatores em batelada de produção de hidrogênio com bagaço de cana-de-açúcar submetido a diferentes prétratamentos.

Hipótese 3: Fatores como concentração de substrato e pH podem favorecer ou inibir populações de bactérias hidrolíticas/fermentativas e, consequentemente, a bioconversão do bagaço de cana-de-açúcar em hidrogênio e ácidos orgânicos.

\section{Objetivos:}

Avaliar o efeito da variação dos fatores concentração de substrato e $\mathrm{pH}$ sobre as respostas produção de hidrogênio e ácidos orgânicos em reatores em batelada.

Avaliar o perfil de açúcares ao longo do tempo a partir da hidrólise do BCA.

Comparar as comunidades de bactérias dos reatores em batelada sob diferentes concentrações de substrato e $\mathrm{pH}$. 
Avaliar a diversidade das populações de bactérias de reatores em batelada com diferentes concentrações de substrato e $\mathrm{pH}$. 


\section{MATERIAL E MÉTODOS}

\subsection{Substrato}

O bagaço de cana-de-açúcar (BCA) utilizado como substrato nos experimentos de produção de hidrogênio foi cedido pela usina São Martinho (Pradópolis, SP, Brazil).

Quatro condições de BCA foram consideradas: a) BCA in natura - foi utilizado tal qual veio da usina São Martinho; (b) BCA autoclavado - foi acondicionado em frascos $\operatorname{Duran}^{\circledR}$, em concentração já ajustada para ser utilizada nos ensaios, e autoclavado $\left(121^{\circ} \mathrm{C}, 1\right.$ atm, por 15 minutos). Após resfriar, o BCA autoclavado foi utilizado nos ensaios de produção de hidrogênio; (c) BCA pré-tratado em reator hidrotérmico - foi realizado em reator hidrotérmico ajustado para $200^{\circ} \mathrm{C}, 16$ bar de pressão e 10 minutos (Soares et al., 2017). Duas fases (líquida ou hidrolisado e a fase sólida) foram obtidas após o tratamento em reator hidrotérmico. A fase sólida foi mantida em temperatura ambiente até a sua completa secagem e, posteriormente, utilizada nos ensaios de produção de hidrogênio em reatores em batelada; (d) BCA pré-tratado em reator hidrotérmico e autoclavado - A fase sólida oriunda do tratamento hidrotérmico foi acondicionada em frascos Duran ${ }^{\circledR}$, em concentração já ajustada para ser utilizada nos ensaios, e autoclavado $\left(121^{\circ} \mathrm{C}\right.$ e 1 atm, por 15 minutos $)$.

\subsection{Meio de cultivo}

Em todas as etapas do presente estudo foi utilizado o meio PCS (solução de peptonacelulose), para favorecer o crescimento de bactérias celulolíticas (Haruta et al., 2002; Kato et al., 2008; Wongwilaiwalin et al., 2010; Wang et al., 2011; Du et al., 2015).

A composição do meio de enriquecimento PCS é bem diferenciada. Os fatores de crescimento e vitaminas estão inclusos em componentes complexos como extrato de levedura e peptona (Tabela 4.1). 
Tabela 4.1: Composição do meio de cultura PCS.

\begin{tabular}{cc}
\hline Composição & Quantidade (q.s.p. 1000 mL) \\
\hline Extrato de levedura & $1,0 \mathrm{~g}$ \\
Peptona & $5,0 \mathrm{~g}$ \\
$\mathrm{CaCO}_{3}$ & $2,0 \mathrm{~g}$ \\
$\mathrm{NaCl}$ & $5,0 \mathrm{~g}$ \\
Substrato celulósico & Concentração de acordo com a etapa do trabalho
\end{tabular}

Procedeu-se da seguinte maneira para o preparo do PCS: (1) Adicionou-se extrato de levedura, peptona, $\mathrm{CaCO}_{3}$ e $\mathrm{NaCl}$ em água ultra purificada, sob agitação lenta e constante; (2) adicionou-se $\mathrm{HCl}(1 \mathrm{M})$ aos poucos, sob agitação até solubilização total do $\mathrm{CaCO}_{3}$; (3) sob agitação, adicionou-se $\mathrm{NaOH}(1 \mathrm{M})$ até pH desejado; (4) o meio de cultura foi transferido para frascos Duran ${ }^{\circledR}$, fechados com tampa butila e rosca plástica e submetidos a esterilização em autoclave a $121^{\circ} \mathrm{C}$ e $1 \mathrm{~atm}$ por 15 minutos.

\subsection{Inóculo fermentativo}

O consórcio bacteriano fermentativo foi obtido a partir do crescimento em celulose em reatores em batelada. Esse consórcio foi cedido pela Universidade do Minho, Portugal. No Laboratório de Processos Biológicos, o consórcio foi preservado a $-80^{\circ} \mathrm{C}$ em glicerol $(50 \%)$.

Essa biomassa foi reativada em frascos $\operatorname{Duran}^{\circledR}$ de 5,0 L com 1,8 L de meio de cultivo PCS com celulose como substrato $(5,0 \mathrm{~g} / \mathrm{L})$ e $0,2 \mathrm{~L}$ do consórcio fermentativo. Os reatores foram submetidos à atmosfera de $\mathrm{N}_{2}(100 \%)$, durante 15 minutos, para a troca gasosa do headspace, fechados com tampa butila e rosca plástica e incubados a $37^{\circ} \mathrm{C}$ por 48 horas.

O inóculo reativado foi, então, centrifugado (8000 rpm por 10 minutos), o sobrenadante descartado e o pellet ressuspendido e concentrado em meio PCS (sem substrato celulósico) em $\mathrm{pH}$ ajustado para cada fase do trabalho. Os pellets ressuspendidos foram acondicionados em frascos Duran ${ }^{\circledR}$, mantendo o volume final de 2,0 L. Os procedimentos de ressuspenção e concentração do pellet foram realizados em atmosfera de $\mathrm{N}_{2}$ (100\%) no meio de cultivo.

O meio PCS com o inóculo concentrado foi utilizado nos reatores de produção de hidrogênio (Figura 4.1). 


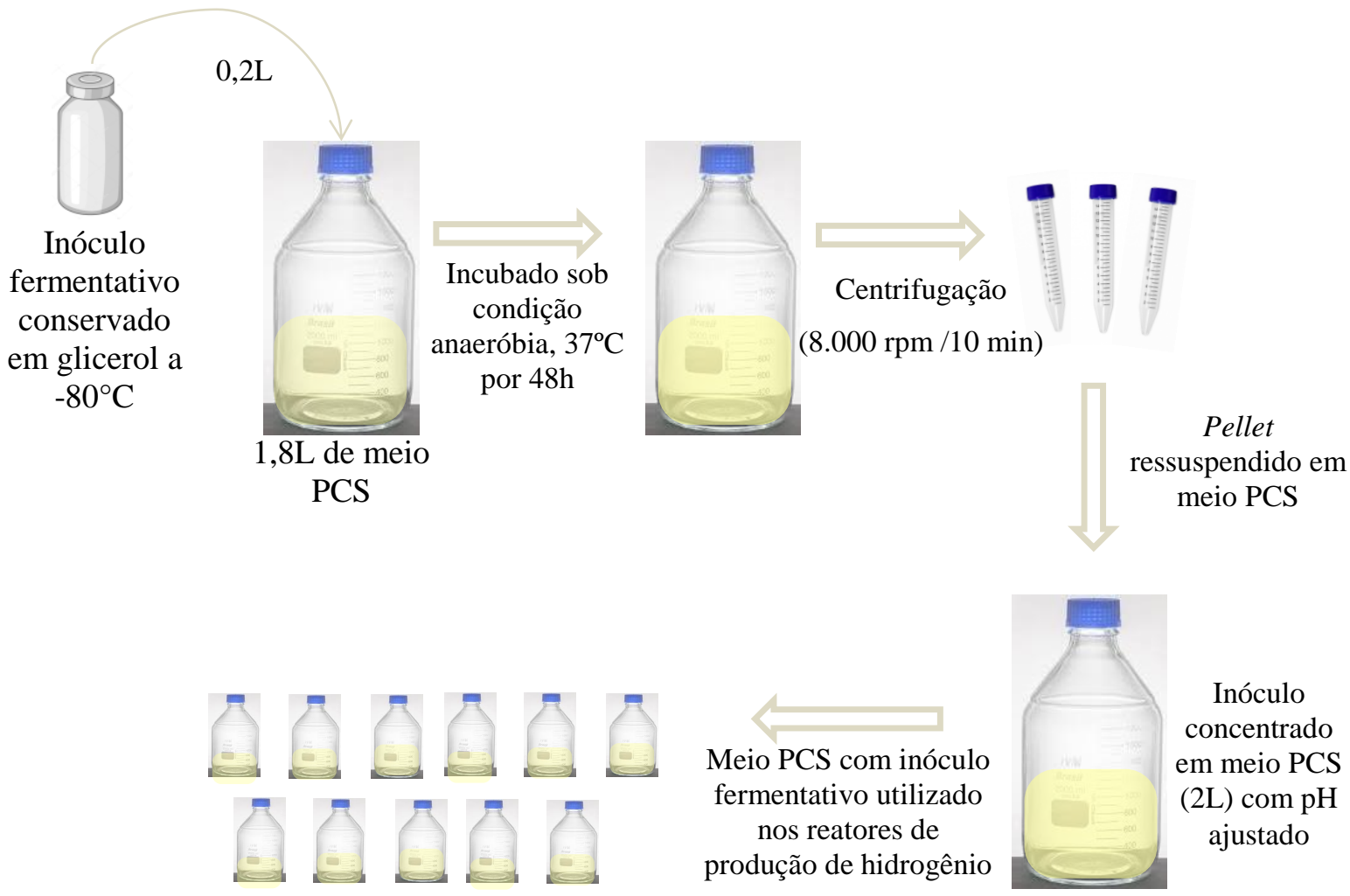

Figura 4.1: Reativação do inóculo fermentativo.

\subsection{Pré-tratamentos do BCA}

Os ensaios para estudar o efeito do pré-tratamento do BCA na produção de hidrogênio foram realizados em frascos $\operatorname{Duran}^{\circledR}$ de $250 \mathrm{~mL}(50 \%$ de volume reacional e $50 \%$ de headspace).

Foram testadas quatro condições: (1) BCA in natura (2) BCA pré-tratado em autoclave, (3) BCA pré-tratado em reator hidrotérmico e (4) BCA pré-tratado em reator hidrotérmico e autoclavado (Figura 4.2). Todas as condições foram realizadas em triplicatas. $\mathrm{O}$ pH inicial do meio foi ajustado para 6,8. 


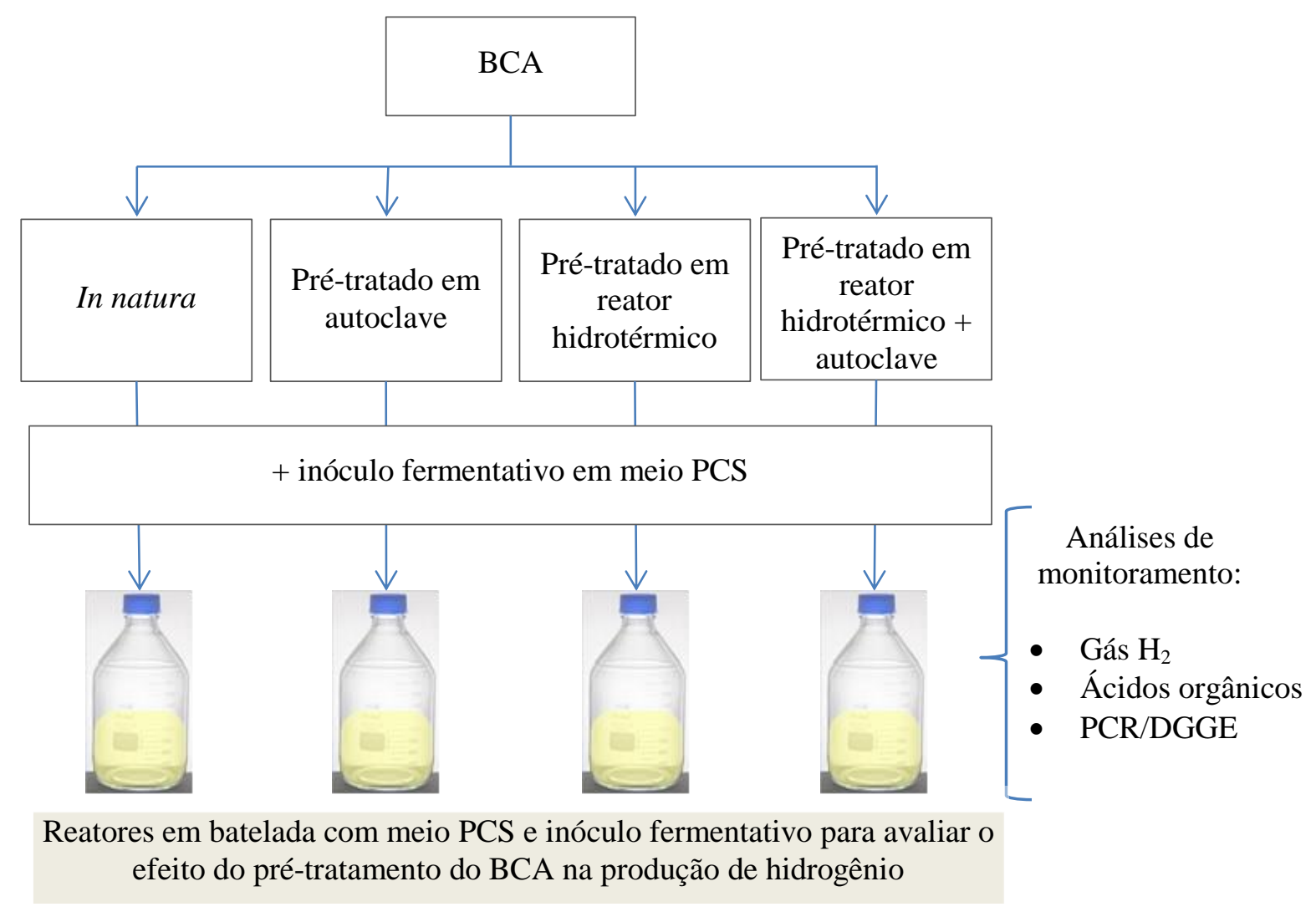

Figura 4.2: Fluxograma da avaliação do pré-tratamento do BCA.

Para a condição 1 (BCA in natura), foram utilizados frascos Duran ${ }^{\circledR}$ de $250 \mathrm{~mL}$ previamente esterilizados em autoclave $\left(121^{\circ} \mathrm{C}, 1\right.$ atm por 15 minutos $)$. Aos frascos foram adicionados 2,0 g/L de BCA in natura e $125 \mathrm{~mL}$ de meio PCS com o inóculo ressuspendido. Os reatores foram submetidos à atmosfera de $\mathrm{N}_{2}$ (100\%), durante 15 minutos, para a troca gasosa do headspace. Findado os 15 minutos, os reatores foram fechados com tampa de butila e rosca plástica, e incubados a $37^{\circ} \mathrm{C}$ por 15 dias.

Para a condição 2 (BCA pré-tratado em autoclave), 2,0 g/L de BCA foram adicionados em frascos Duran ${ }^{\circledR}$ de $250 \mathrm{~mL}$ e esterilizados em autoclave $\left(121^{\circ} \mathrm{C}, 1 \mathrm{~atm}\right.$ por 15 minutos). Após autoclavagem, foram adicionados $125 \mathrm{~mL}$ de meio PCS com o inóculo ressuspendido. Os reatores foram submetidos à atmosfera de $\mathrm{N}_{2}$ (100\%), durante 15 minutos, para a troca gasosa do headspace. Findado os 15 minutos, os reatores foram fechados com tampa de butila e rosca plástica, e incubados a $37^{\circ} \mathrm{C}$ por 15 dias.

Para a condição 3 (BCA pré-tratado em reator hidrotérmico), foram utilizados frascos Duran ${ }^{\circledR}$ de $250 \mathrm{~mL}$ previamente esterilizados em autoclave $\left(121^{\circ} \mathrm{C}, 1 \mathrm{~atm}\right.$ por 15 minutos). Aos frascos foram adicionados 2,0 g/L de BCA pré-tratado em reator hidrotérmico (fase sólida) e $125 \mathrm{~mL}$ de meio PCS com o inóculo ressuspendido. Os reatores foram submetidos à 
atmosfera de $\mathrm{N}_{2}(100 \%)$, durante 15 minutos, para a troca gasosa do headspace. Findado os 15 minutos, os reatores foram fechados com tampa de butila e rosca plástica, e incubados a $37^{\circ} \mathrm{C}$ por 15 dias.

Para a condição 4 (BCA pré-tratado em reator hidrotérmico e autoclavado), 2,0 g/L de BCA pré-tratado em reator hidrotérmico (fase sólida) foram adicionados em frascos Duran ${ }^{\circledR}$ de $250 \mathrm{~mL}$ e transferidos para autoclave $\left(121^{\circ} \mathrm{C}, 1 \mathrm{~atm}\right.$ por 15 minutos $)$. Após autoclavagem, foram adicionados $125 \mathrm{~mL}$ de meio PCS com o inóculo ressuspendido. Os reatores foram submetidos à atmosfera de $\mathrm{N}_{2}(100 \%)$, durante 15 minutos, para a troca gasosa do headspace. Findado os 15 minutos, os reatores foram fechados com tampa de butila e rosca plástica, e incubados a $37^{\circ} \mathrm{C}$ por 15 dias.

Para acompanhar a produção de gases e ácidos, foram realizadas análises de cromatografia gasosa e líquida, respectivamente. A similaridade entre as comunidades bacterianas presentes nos reatores foi analisada por PCR/DGGE.

\subsection{Planejamento fatorial}

A fim de analisar os efeitos da concentração de substrato (BCA autoclavado) e $\mathrm{pH}$ sobre a produção de hidrogênio e ácidos orgânicos, foi empregado um delineamento composto central (DCC) (planejamento fatorial $2^{2}$ ) em cinco níveis $(+1,42 ;+1,0 ; 0 ;-1,0$; 1,42) e duas repetições do ponto central. Desta forma, foram monitorados reatores em bateladas (R1 a R10), com diferentes tratamentos (combinações de concentração de substrato e pH) (Figura 4.3). 


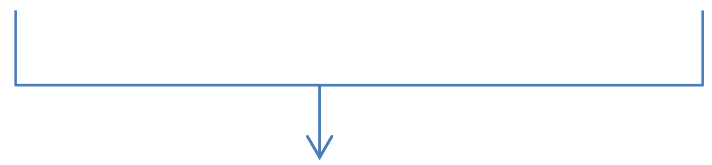

Reatores do Planejamento fatorial com diferentes combinações de concentração de substrato e pH

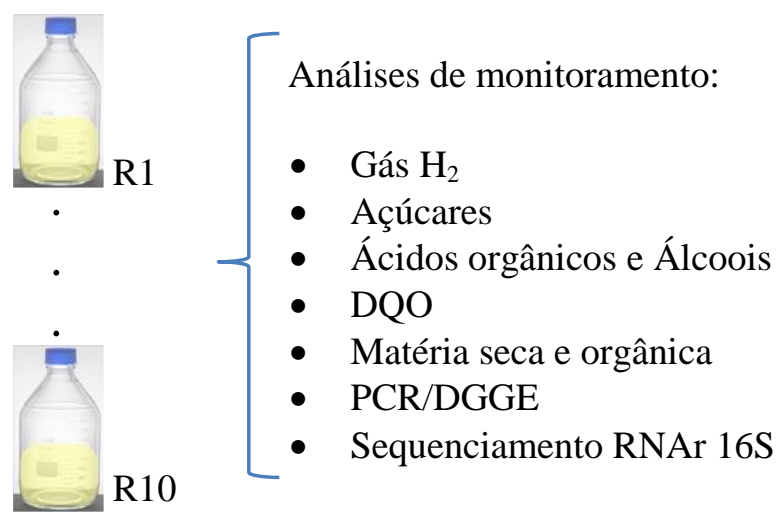

Figura 4.3: Fluxograma dos ensaios do planejamento fatorial.

Os tratamentos R9 e R10 foram as réplicas no ponto central, com finalidade de estimar a soma dos quadrados dos erros. Os experimentos foram realizados em triplicatas, totalizando 30 reatores (Tabela 4.2).

O teste ANOVA com os dados do delineamento experimental foi realizado para obterse o valor de Fcalculado e compará-lo ao Ftabelado. Sendo o modelo estatisticamente significativo se Fcalculado > Ftabelado.

Todos os testes estatísticos foram realizados utilizando o programa Statistica 10. 
Tabela 4.2: Planejamento fatorial $2^{2}$ para otimização de concentração de substrato (BCA autoclavado) e pH.

\begin{tabular}{|c|c|c|c|c|c|c|c|c|c|}
\hline \multirow[b]{2}{*}{ Bloco } & \multirow[b]{2}{*}{$\begin{array}{c}\text { Tratamento } \\
\text { (Reator) }\end{array}$} & \multicolumn{6}{|c|}{ Valores codificados } & \multicolumn{2}{|c|}{ Valores decodificados } \\
\hline & & \multicolumn{2}{|c|}{$\begin{array}{l}\text { Pontos } \\
\text { cúbicos }\end{array}$} & \multicolumn{2}{|c|}{$\begin{array}{l}\text { Pontos } \\
\text { axiais }\end{array}$} & \multicolumn{2}{|c|}{$\begin{array}{l}\text { Ponto } \\
\text { central }\end{array}$} & $\begin{array}{c}\text { Substrato } \\
(\mathrm{g} / \mathrm{L})\end{array}$ & $\mathrm{pH}$ \\
\hline \multirow{10}{*}{1} & $1(\mathrm{R} 1)$ & -1 & -1 & & & & & 2,0 & 5,0 \\
\hline & 2 (R2) & -1 & +1 & & & & & 2,0 & 7,0 \\
\hline & 3 (R3) & +1 & -1 & & & & & 8,0 & 5,0 \\
\hline & $4(\mathrm{R} 4)$ & +1 & +1 & & & & & 8,0 & 7,0 \\
\hline & $5(\mathrm{R} 5)$ & & & $-1,42$ & 0 & & & 0,8 & 6,0 \\
\hline & $6(\mathrm{R} 6)$ & & & $+1,42$ & 0 & & & 9,2 & 6,0 \\
\hline & 7 (R7) & & & 0 & $-1,42$ & & & 5,0 & 4,6 \\
\hline & $8(\mathrm{R} 8)$ & & & 0 & $+1,42$ & & & 5,0 & 7,4 \\
\hline & 9 (R9) & & & & & 0 & 0 & 5,0 & 6,0 \\
\hline & $10(\mathrm{R} 10)$ & & & & & 0 & 0 & 5,0 & 6,0 \\
\hline
\end{tabular}

Para montagem dos reatores em batelada, os frascos de Duran ${ }^{\circledR}$ com BCA (concentração de acordo com a Tabela 4.2) foram submetidos a tratamento em autoclave $\left(121^{\circ} \mathrm{C}, 1 \mathrm{~atm}\right.$ por 15 minutos). Após esfriar, foram adicionados $125 \mathrm{~mL}$ de meio PCS (pH ajustado de acordo com a Tabela 4.2) com o inóculo ressuspendido. Os reatores foram submetidos à atmosfera de $\mathrm{N}_{2}(100 \%)$, durante 15 minutos, para a troca gasosa do headspace. Findado os 15 minutos, os reatores foram fechados com tampa butila e rosca plástica, e incubados a $37^{\circ} \mathrm{C}$ por 15 dias.

\subsection{Análises físico-químicas e cromatográficas}

\subsubsection{Determinação de Carboidratos}

A metodologia de determinação de carboidratos foi realizada de acordo com o protocolo NREL, National Renewable Energy Laboratory, (Sluiter et al., 2006) por cromatografia líquida de alta eficiência (HPLC, High performance liquid chromatography). 
Para o preparo das amostras, 2,5 $\mathrm{mL}$ da fase líquida foram retiradas dos reatores em batelada e acondicionadas em tubos de digestão, seguida pela adição de $0,18 \mathrm{~mL}$ de $\mathrm{H}_{2} \mathrm{SO}_{4}$ $(72 \% \mathrm{p} / \mathrm{p})$. Os tubos foram submetidos à autoclave $\left(121^{\circ} \mathrm{C}\right.$ e $\left.1 \mathrm{~atm}\right)$ por $1 \mathrm{~h}$. Após o tempo determinado e com os tubos em temperatura ambiente, as alíquotas líquidas obtidas foram neutralizadas com $\mathrm{CaCO}_{3}$ até ajuste de $\mathrm{pH}$ entre 5,0 e 9,0. As amostras foram, então, passadas por cartuchos Sep-Pak C-18 e filtros de 0,2 $\mu \mathrm{m}$ de tamanho de poro e analisadas por HPLC.

Os carboidratos foram quantificados em HPLC $\left(\right.$ Shimadzu $^{\circledR}$ ) equipado com coluna Aminex HPX-87P (300 mm x 7,8 mm, BioRad) e software Class-VP (Shimadzu $\left.{ }^{\circledR}\right) . \mathrm{H}_{2} \mathrm{SO}_{4}$ $0,005 \mathrm{M}(0,01 \mathrm{~N})$ foi utilizado como fase móvel e temperatura do forno foi mantida a $43{ }^{\circ} \mathrm{C}$.

Para os cálculos de eficiência de conversão de carboidratos, considerou-se concentração de carboidratos no início do experimento (dia 2) $\left(C_{i}\right)$ e a concentração de carboidratos no final do experimento $\left(C_{f}\right)$.

Sendo, Conversão $=\frac{C_{i}-C_{f}}{C_{i}} \times 100$

Equação 4.1

\subsubsection{Determinação de ácidos orgânicos e álcoois}

Para determinação de ácidos orgânicos e álcoois procedeu-se a filtração das amostras em filtros de 0,2 $\mu \mathrm{m}$ de diâmetro de poro. Em 2,0 $\mathrm{mL}$ de amostra filtrada foram adicionados $0,08 \mathrm{~mL}$ de $\mathrm{H}_{2} \mathrm{SO}_{4}(2,0 \mathrm{M})$.

A determinação de ácidos orgânicos voláteis e álcoois foi realizada em HPLC $\left(\right.$ Shimadzu $^{\circledR}$ ) equipado com coluna Aminex HPX-87H (300 mm x 7,8 mm, BioRad) e software Class-VP (Shimadzu. Os ácidos orgânicos foram aferidos em detector SDP-M10 AVP e os álcoois em detector RID-10A. Foi utilizado ácido sulfúrico 0,005M como fase móvel e as condições operacionais da coluna foram fluxo de $0,5 \mathrm{~mL} / \mathrm{min}$ e $43^{\circ} \mathrm{C}$.

\subsubsection{Demanda química de oxigênio}

A demanda química de oxigênio (DQO) foi realizada de acordo com Standard Methods for the Examination of Water and Wastewater (APHA, 2005).

Para o cálculo da DQO equivalente levou-se em consideração a concentração dos açúcares (hexoses e pentoses), dos ácidos orgânicos e etanol. As reações e seus respectivos 
coeficientes de conversão para o cálculo da DQO equivalente estão apresentados na Tabela 4.3 .

Tabela 4.3: Reações e coeficientes de conversão utilizados para o cálculo da DQO equivalente.

\begin{tabular}{ccc}
\hline Produtos & Reação & $\begin{array}{r}\text { Coeficiente de conversão } \\
\text { (mg DQO/mg produto) }\end{array}$ \\
\hline Hexose & $\mathrm{C}_{6} \mathrm{H}_{12} \mathrm{O}_{6}+6 \mathrm{O}_{2} \rightarrow 6 \mathrm{CO}_{2}+6 \mathrm{H}_{2} \mathrm{O}$ & 1,07 \\
Pentose & $\mathrm{C}_{5} \mathrm{H}_{12} \mathrm{O}_{5}+5,5 \mathrm{O}_{2} \rightarrow 5 \mathrm{CO}_{2}+5 \mathrm{H}_{2} \mathrm{O}$ & 1,30 \\
Ácido acético & $\mathrm{C}_{2} \mathrm{H}_{4} \mathrm{O}_{2}+2 \mathrm{O}_{2} \rightarrow 2 \mathrm{CO}_{2}+2 \mathrm{H}_{2} \mathrm{O}$ & 1,07 \\
Ácidos butírico e isobutírico & $\mathrm{C}_{4} \mathrm{H}_{8} \mathrm{O}_{2}+5 \mathrm{O}_{2} \rightarrow 4 \mathrm{CO}_{2}+4 \mathrm{H}_{2} \mathrm{O}$ & 1,82 \\
Ácido fórmico & $\mathrm{CH}_{2} \mathrm{O}_{2}+0,5 \mathrm{O}_{2} \rightarrow \mathrm{CO}_{2}+\mathrm{H}_{2} \mathrm{O}$ & 0,35 \\
Ácido lático & $\mathrm{C}_{3} \mathrm{H}_{6} \mathrm{O}_{3}+3 \mathrm{O}_{2} \rightarrow 3 \mathrm{CO}_{2}+3 \mathrm{H}_{2} \mathrm{O}$ & 1,07 \\
Ácido propiônico & $\mathrm{C}_{3} \mathrm{H}_{6} \mathrm{O}_{2}+3,5 \mathrm{O}_{2} \rightarrow 3 \mathrm{CO}_{2}+3 \mathrm{H}_{2} \mathrm{O}$ & 1,51 \\
Ácido succínico & $\mathrm{C}_{4} \mathrm{H}_{6} \mathrm{O}_{4}+3,5 \mathrm{O}_{2} \rightarrow 4 \mathrm{CO}_{2}+3 \mathrm{H}_{2} \mathrm{O}$ & 0,95 \\
Ácidos valérico e isovalérico & $\mathrm{C}_{5} \mathrm{H}_{10} \mathrm{O}_{2}+6,5 \mathrm{O}_{2} \rightarrow 5 \mathrm{CO}_{2}+5 \mathrm{H}_{2} \mathrm{O}$ & 2,04 \\
Etanol & $\mathrm{C}_{2} \mathrm{H}_{6} \mathrm{O}+3 \mathrm{O}_{2} \rightarrow 2 \mathrm{CO}_{2}+3 \mathrm{H}_{2} \mathrm{O}$ & 2,08 \\
\hline
\end{tabular}

\subsubsection{Determinação de hidrogênio}

A determinação de hidrogênio no headspace foi realizada por cromatografia gasosa. O equipamento utilizado foi da marca Shimadzu ${ }^{\circledR}$, modelo GC-2010 com detector de condutividade térmica (TCD) e gás argônio como carreador. As temperaturas de operação do injetor, do detector e da coluna foram de $30^{\circ} \mathrm{C}, 200^{\circ} \mathrm{C}$ e $300^{\circ} \mathrm{C}$, respectivamente. A amostra do headspace $(0,5 \mathrm{~mL})$ foi retirada dos reatores pressurizados com auxílio de uma seringa gastight com trava. A pressão dos reatores foi aferida por Indicador de pressão modelo MOD50, T\&S. O volume de gás foi convertido em $\mu$ mol de acordo com a temperatura e pressão medidas, a partir de curva de calibração. 


\subsection{Ajuste dos dados experimentais de hidrogênio}

Os dados de produção acumulada de hidrogênio foram ajustados por meio da equação de Gompertz, modificada por Zwietering et al. (1990). Este modelo tem sido utilizado para descrever o progresso da produção acumulativa de hidrogênio em experimentos em batelada, baseado na relação entre crescimento e metabolismo bacteriano (Guo et al., 2010; Lay, 2001; Rabelo et al., 2017; Soares et al., 2017).

A partir da equação de Gompertz modificada (Equação 4.2) foi possível estimar o Potencial de Produção de hidrogênio $(P)$ em produção molar (mmol/L) (Singh et al., 2010), Velocidade máxima de Produção de hidrogênio $\left(R_{m}\right)$ e Tempo para início da produção de hidrogênio $(\lambda)$.

$$
H=P \cdot \exp \left\{-\exp \left[\frac{R_{m} \cdot e}{P}(\lambda-\mathbf{t})+1\right]\right\}
$$

Equação 4.2

Na Equação 4.2, $H$ é a produção cumulativa de hidrogênio e $t$ é o tempo de operação (dias) e $e$ é 2,71 .

\subsection{Determinação da matéria seca e matéria orgânica}

A determinação da matéria seca (MS) e matéria orgânica (MO) das amostras dos reatores foi conduzida de acordo com o protocolo de sólidos totais e sólidos totais voláteis do Standard Methods for the Examination of Water and Wastewater (APHA, 2005).

Esta análise gravimétrica foi realizada com a amostra total $(50 \mathrm{~mL})$ de reatores que foram incubados nas mesmas condições e pelo mesmo tempo que os reatores do experimento fatorial, entretanto com volume reduzido (volume total $100 \mathrm{~mL}$, sendo $50 \%$ headspace e $50 \%$ volume útil).

Para determinação da matéria seca, utilizou-se o peso de cadinhos previamente secos em estufa a $105^{\circ} \mathrm{C}$ por 24 horas (M1), o peso da massa total dos reatores seca a $105^{\circ} \mathrm{C}$ por 24 horas (M2) e o volume útil dos reatores (V).

$$
\text { Sendo, } M S=\left[\frac{M 2(g)-M 1(g)}{V(L)}\right]
$$


A determinação da MO foi obtida após a análise da MS, os cadinhos contendo a massa seca total foram transferidos para mufla a $550^{\circ} \mathrm{C}$ por 2 horas (tempo suficiente para atingir massa constante) e, após esfriar em dessecadores, foi aferido o peso da massa (M3).

$$
\text { Sendo, } M O=M S-\left[\frac{M 2(g)-M 3(g)}{V(L)}\right]
$$

\subsection{Análises microbiológicas}

\subsubsection{Exames microscópicos}

Os exames microscópicos foram realizados em microscópio óptico Olympus BX60FLA por meio de luz comum. Para diferenciação das bactérias, foi efetuada a técnica de coloração de Gram, conforme procedimento descrito em DSM (1991).

\subsubsection{Contagem de bactérias anaeróbias viáveis totais}

A contagem de bactérias foi realizada por meio da técnica de plaqueamento por Pour plate, de acordo com Standard Methods for the Examination of Water and Wastewater (APHA, 2005), sob condição anaeróbia.

Inicialmente, foi realizada diluição seriada das amostras oriundas dos reatores em batelada. Para tanto, 1,0 mL de amostra líquida dos reatores foram transferidas para tubos de ensaio contendo $9,0 \mathrm{~mL}$ de água peptonada $(0,1 \% \mathrm{p} / \mathrm{v})$ previamente esterilizada, constituindo a diluição $10^{-1}$. O mesmo procedimento foi repetido até a diluição $10^{-10}$.

Para o plaqueamento, 1,0 mL de amostras oriundas dos tubos de diluição $\left(10^{-6}\right.$ a $\left.10^{-10}\right)$ foram adicionados em placas de petri estéreis e, logo em seguida, foram adicionados $15 \mathrm{~mL}$ de meio RCM (Reinforced Clostridia Medium, Oxoid ${ }^{\circledR}$ ) preparado com ágar nutriente $(1,5 \%$ $\mathrm{p} / \mathrm{v}$ ). As placas foram homogeneizadas, em forma de 8, e mantidas entreabertas para completa solidificação do meio. As placas foram, então, incubadas invertidas em jarras de anaerobiose contendo sachê de anaerobiose (Anaerobac, Probac $\left.^{\circledR}\right)$, em estufas a $37^{\circ} \mathrm{C}$.

Todo procedimento foi realizado dentro de capela de exaustão sob condições estéreis.

Após 48 horas, a contagem de colônias foi realizada, considerando as diluições com 30 e 300 colônias (Black e Black, 2015). Os resultados foram reportados como unidade formadora de colônias por mililitro (UFC/mL). 


\subsubsection{Biologia Molecular}

\subsubsection{Eletroforese em Gel de Gradiente Desnaturante}

A comparação da comunidade bacteriana foi realizada a partir da imagem do perfil das bandas padrões do DGGE (Eletroforese em Gel de Gradiente Desnaturante), com a construção de matrizes por meio do programa Bionumerics, para servir como base para os cálculos de coeficiente de similaridade. O agrupamento do dendograma foi realizado usando algoritmo UPGMA (Unweighted Pair Group Method with Arithmetic Averages) e o coeficiente de similaridade utilizado foi o coeficiente de Pearson.

Para tanto, foi realizada a extração do DNA conforme protocolo de Griffiths et al. (2000). A partir do DNA extraído das amostras dos reatores em batelada foi realizada a amplificação através da reação de polimerização em cadeia (PCR) com iniciadores 968FGC1401R (Nubel et al., 1996). As condições de amplificação utilizadas para a PCR estão descritas na Tabela 4.4.

Tabela 4.4: Condições da programação do termociclador para PCR.

\begin{tabular}{cc}
\hline Programação & Condição \\
Primer & $968 \mathrm{FGC}-1401 \mathrm{R}$ \\
Pré- Desnaturação & $94^{\circ} \mathrm{C} / 5 \mathrm{mim}$ \\
$\mathrm{N}^{\circ}$ de ciclos & 35 \\
Desnaturação & $94^{\circ} \mathrm{C} / 45 \mathrm{seg}$ \\
Anelamento & $55^{\circ} \mathrm{C} / 45 \mathrm{seg}$ \\
Extensão & $72^{\circ} \mathrm{C} / 60 \mathrm{seg}$ \\
Final da extensão & $72^{\circ} \mathrm{C} / 5 \mathrm{~min}$ \\
Resfriamento & $4{ }^{\circ} \mathrm{C}$ \\
\hline
\end{tabular}

Os produtos da PCR foram verificados em eletroforese em gel de agarose a 1,4\% (p/v), visualizado em câmara de transiluminador UV (Stratagene - Eagle Eye II). 
Os fragmentos amplificados foram separados em eletroforese com gel em gradiente desnaturante (DGGE). Por meio desta técnica tem-se a separação dos fragmentos de DNA de mesmo tamanho, porém com sequência de nucleotídeos diferentes.

Neste estudo, o gel foi preparado com gradiente desnaturante (formamida e uréia) nas concentrações de $45 \%$ e $65 \%$. O sistema utilizado foi DGGE D CodeTM - Universal Mutation Detection System (Bio Rad, Inc., Hercules, California). As condições durante a eletroforese foram temperatura constante de $60^{\circ} \mathrm{C}, 75 \mathrm{~V}$ por 16 horas. Após este período, o gel foi submetido a coloração com solução TAE 1X (tampão Tris-Acetato-EDTA) contendo 1,0 $\mathrm{g} / \mathrm{mL}$ de brometo de etídeo por 10 minutos e lavado com água ultrapurificada. O aparelho utilizado para leitura do padrão de bandas do gel foi transiluminador UV (Stratagene - Eagle Eye TM III), sob exposição a luz UV (254 nm). O dendograma foi construído usando software Bionumerics versão 2.5, com coeficiente de similaridade de Correlação de Pearson.

\subsubsection{Sequenciamento do gene RNAr $16 S$}

A caracterização microbiana por sequenciamento massivo foi realizada no MR DNA (www.mrdnalab.com, Shallowater, TX, EUA), por meio da plataforma Illumina MiSeq seguindo as diretrizes do fabricante. Os iniciadores utilizados foram 341F-785R (região variável V5-V4 de RNAr 16S). Os dados foram processados com MR DNA analysis pipeline (MR DNA, Shallowater, TX, EUA). As unidades taxonômicas operacionais (OTUs) foram definidas por agrupamento com 3\% de divergência (97\% de similaridade). As OTUs finais foram classificadas usando BLASTn, com banco de dados de NCBI e RDP-II (www.ncbi.nlm.nih.gov, http://rdp.cme.msu.edu).

O sequenciamento foi realizado nas seguintes amostras: (1) Consórcio bacteriano fermentativo (inóculo), (2) substrato - bagaço de cana-de-açúcar pré-tratado em autoclave, (3) amostra do reator em batelada do ponto central (R9) e 4) amostra do reator em batelada das condições otimizadas (Rotm).

Os dados de sequência do inóculo bacteriano fermentativo, BCA, R9 e Rotm foram depositados no NCBI, sob os números de acesso: PRJNA383576 (SRX2754705).

Os índices de diversidade Shannon $(H)$ e Dominância $(D)$ foram utilizados para analisar a diversidade das amostras. 


\section{RESULTADOS E DISCUSSÃO}

\subsection{Efeito do pré-tratamento do BCA na produção de hidrogênio}

Obteve-se produções de hidrogênio distintas para as condições dos reatores em batelada com BCA in natura, BCA pré-tratado em autoclave, BCA pré-tratado em sistema hidrotérmico e, finalmente, em sistema hidrotérmico e autoclave (Figura 5.1).

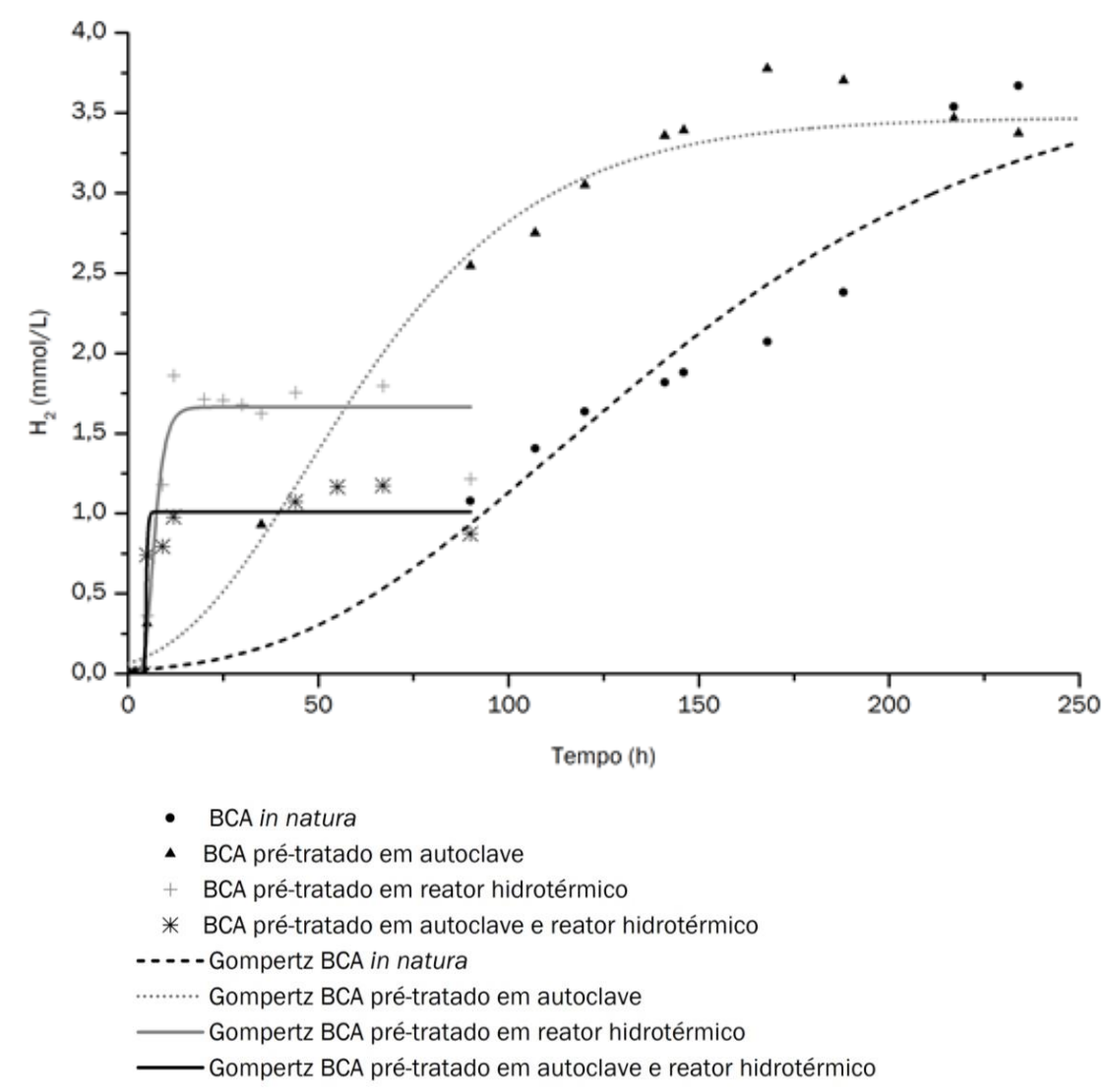

Figura 5.1: Produção de hidrogênio com BCA in natura e pré-tratado como substrato.

A partir do ajuste por meio do modelo de Gompertz verificou-se que os valores de produção de hidrogênio dos reatores incubados com BCA in natura e BCA autoclavado foram próximos; ou seja, de 3,47 e 3,79 mmol/L, respectivamente (Tabela 5.1). Todavia, observou-se para as condições dos reatores com BCA pré-tratado em reator hidrotérmico e BCA pré-tratado em reator hidrotérmico e autoclavado menor produção de hidrogênio $(1,67$ e 1,01 $\mathrm{mmol} / \mathrm{L}$, respectivamente). 
Tabela 5.1: $P, R_{m}$ e $\lambda$ dos reatores de produção de hidrogênio incubados com BCA in natura e em diferentes condições de pré-tratamentos.

\begin{tabular}{ccccc}
\hline & $\begin{array}{c}P \\
(\mathrm{mmol} / \mathrm{L})\end{array}$ & $\begin{array}{c}R m \\
(\mathrm{mmol} / \mathrm{L} \cdot \mathrm{d})\end{array}$ & $\begin{array}{c}\lambda \\
(\mathrm{h})\end{array}$ & $\mathrm{R}^{2}$ \\
\hline $\begin{array}{c}\text { Reator com BCA in natura }(\mathrm{Rn}) \\
\text { Reator com BCA autoclavado (Ra) }\end{array}$ & 3,47 & 0,04 & 13,10 & 0,98 \\
$\begin{array}{c}\text { Reator com BCA pré-tratado em reator } \\
\text { hidrotérmico (Rh) }\end{array}$ & 3,79 & 0,02 & 20,72 & 0,94 \\
$\begin{array}{c}\text { Reator com BCA pré-tratado reator } \\
\text { hidrotérmico e autoclave (Rha) }\end{array}$ & 1,67 & 0,3 & 4,19 & 0,95 \\
\hline
\end{tabular}

Mesmo com valores semelhantes de $P(3,47$ e 3,79 mmol/L, respectivamente) para as condições dos reatores com BCA in natura (Rn) e BCA autoclavado (Ra), observou-se diferentes velocidades de produção de hidrogênio ( 0,04 e $0,02 \mathrm{mmol} / \mathrm{l}$.d, respectivamente).

Kim et al (2003) também aplicaram o pré-tratamento térmico $\left(121^{\circ} \mathrm{C}, 1 \mathrm{~atm}\right.$ por 30 minutos) em resíduos de lodos ativados e relataram que, após o pré-tratamento, partículas orgânicas do substrato foram convertidas em compostos de menor peso molecular como carboidratos solúveis. No estudo de Kim et al. (2003), o aumento da produção de biogás de 13,4\% para $37,8 \%$ foi observado com o substrato in natura e com o substrato pré-tratado, respectivamente. No presente estudo, a velocidade de produção de hidrogênio em Ra (Reator com BCA autoclavado) foi o dobro da velocidade de produção de hidrogênio em Rn Reator com BCA in natura), o que pode ter sido decorrente do pré-tratamento térmico (em autoclave) que favoreceu a hidrólise e fermentação do substrato resultando em mais rápida produção de hidrogênio.

Todavia, verificou-se na análise comparativa de $\mathrm{Rn}$ e $\mathrm{Ra}$ com as condições dos reatores com BCA pré-tratado em sistema hidrotérmico $(\mathrm{Rh})$ e BCA pré-tratado em reator hidrotérmico e autoclavado (Rha) maior discrepância em relação a $P$. Provavelmente, a menor produção de hidrogênio em $\mathrm{Rh}$ e Rha (1,67 e 1,01 mmol/L, respectivamente) pode ter sido decorrente do pré-tratamento hidrotérmico comum a estes dois reatores. Durante o prétratamento hidrotérmico podem ser formados compostos, tais como furfural, 5hidroximetilfurfural, ácido acético e fenóis que podem inibir a atividade fermentativa (Rasmussen et al., 2014). Estes compostos podem ter sido formados durante o pré-tratamento 
hidrotérmico e podem ter inibido a hidrólise e fermentação do BCA em Rh e Rha, resultando em baixa produção de hidrogênio.

Soares (2017) também aplicou pré-tratamento hidrotérmico sob as mesmas condições do presente estudo $\left(200^{\circ} \mathrm{C}, 16\right.$ bar e 10 minutos $)$ em BCA para avaliar a produção de hidrogênio em reatores em batelada sob condição mesofílica $\left(37^{\circ} \mathrm{C}\right)$. Os autores avaliaram diferentes concentrações de substrato $(3,58$ a $6,42 \mathrm{~g} / \mathrm{L})$ e extrato de levedura $(1,0$ a 3,42 g/L) para obter a melhor produção de hidrogênio. Mesmo com maiores concentrações de substrato, os resultados de Soares (2017) foram de 0,31 a 1,53 mmol/L, semelhantes àqueles obtidos no presente estudo (1,67 e 1,01 mmol/L, em $\mathrm{Rh}$ e Rha, respectivamente) corroborando com a hipótese de inibição da atividade fermentativa.

Além disso, durante o pré-tratamento hidrotérmico foram liberados açúcares $(55,0$ e $52,6 \mathrm{mg} / \mathrm{L}$ em $\mathrm{Rh}$ e Rha, respectivamente) que podem ter contribuído com a produção de hidrogênio. Nas amostras iniciais de Rn e Ra não foram observados açúcares solúveis, desta forma, nestes reatores, a produção de hidrogênio foi decorrente da hidrólise do BCA.

Nas amostras iniciais dos reatores Rh e Rha observou-se maior concentração de ácidos orgânicos totais (4,6 e 2,9 g/L, respectivamente) em relação aquelas obtidas em 24 horas de operação (1,5 e 1,2 g/L em Rh e Rha, respectivamente) e 100 horas $(2,6$ e 2,1 g/L em Rh e Rha, respectivamente). Por outro lado, nas amostras de $\mathrm{Rn}$ e Ra, observou-se valores crescentes de ácidos orgânicos ao longo do tempo de fermentação (Figura 5.2). Provavelmente, em $\mathrm{Rn}$ e $\mathrm{Ra}$, os ácidos orgânicos foram formados como subprodutos da fermentação do BCA, atestando a atividade fermentativa nestes reatores. 

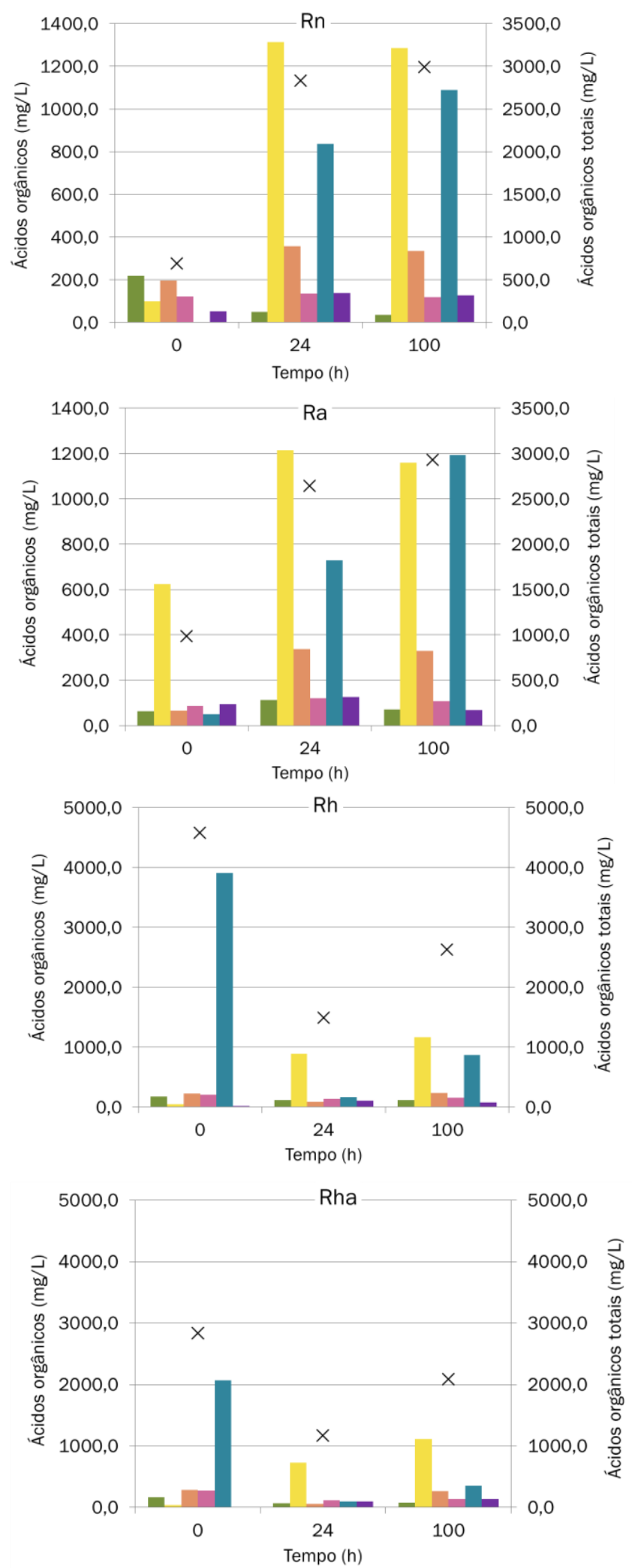

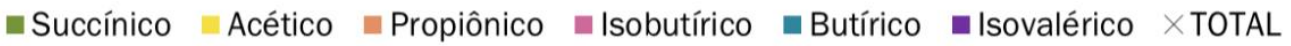

Figura 5.2: Ácidos orgânicos nos reatores em batelada dos testes de pré-tratamento: Rn (reator com BCA in natura), Ra (reator com BCA autoclavado), Rh (reator com BCA pré-tratado hidrotermicamente) e Rha (reator com BCA pré-tratado hidrotermicamente e autoclavado). 
Em Rn e Ra, os principais ácidos orgânicos observados foram acético (1,3 e 1,2 g/L, respectivamente) e butírico (1,1 e 1,2 g/L, respectivamente).

Ratti et al. (2015) avaliaram produção de hidrogênio a partir do consórcio microbiano do bagaço de cana-de-açúcar in natura (BCAn) para fermentar a celulose do BCA pré-tratado (BCAp, explosão a vapor e deslignificação alcalina). Os autores avaliaram diferentes concentrações de BCAn $(0,5$ - 2,0 g/L) e BCAp $(0,5$ - 2,0 g/L) e verificaram produção de hidrogênio em todos os ensaios ( 0,8 até $7,04 \mathrm{mmol} / \mathrm{L})$ concomitante com a produção, principalmente, de ácidos acéticos e butírico. Soares et al. (2017) também avaliaram a produção de hidrogênio a partir de 2,0 g/L de BCA pré-tratado (em reator hidrotérmico $200^{\circ} \mathrm{C}, 16$ bar por 10 minutos), a $60,0^{\circ} \mathrm{C}$, e observaram máxima produção de hidrogênio de 17,7 mmol/L, juntamente com 50,44 mg/L de ácido acético e 209,71 mg/L de ácido butírico.

Assim como no presente estudo, os ácidos acético e butírico têm sido amplamente reportados na fermentação de materiais lignocelulósicos (Ratti et al., 2013; Rabelo et al., 2017; Soares et al., 2017) e são produtos solúveis desejáveis do ponto de vista da maior produção de hidrogênio. Quando a rota do ácido acético é favorecida são formados concomitantemente 4 mols de hidrogênio, todavia, quando a rota do ácido butírico é favorecida, formam-se 2 mols de hidrogênio (Li e Fang, 2007)

As populações de bactérias dos reatores foram analisadas por meio de DGGE (Figura 5.3). Verificou-se mudança no perfil de bandas do gel de DGGE de acordo com as condições de pré-tratamento do BCA, o que pode indicar que as bactérias autóctones do BCA influenciaram na composição das populações de bactérias alóctones do consórcio fermentativo utilizado como inóculo. A mudança no perfil de bandas pode também indicar que o pré-tratamento aplicado (ou a ausência) influenciou, de modo geral, na composição de bactérias dos reatores em batelada.

Observou-se similaridade de $86 \%$ das populações de bactérias do reator com BCA in natura e aquele com BCA pré-tratado hidrotermicamente. A similaridade entre as populações desses reatores com aquele com BCA autoclavado foi de 54\%. Apenas 30\% de similaridade foi observada entre as populações do reator com BCA pré-tratado hidrotermicamente e autoclavado e as populações dos demais reatores. 


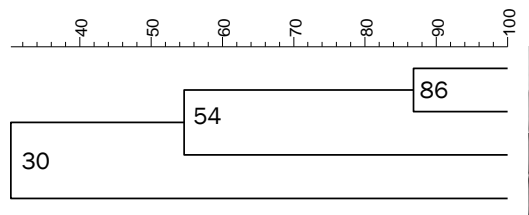

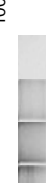

BCA in natura

BCA reator hidrotérmico

BCA autoclavado

BCA reator hidrotérmico + autoclavado

Figura 5.3: Dendograma baseado no coeficiente de similaridade de Pearson a partir do padrão de bandas do DGGE do gene RNAr 16S para o Domínio Bacteria dos reatores de produção de hidrogênio com BCA in natura, pré-tratado em autoclave, pré-tratado em reator hidrotérmico e pré-tratado em reator hidrotérmico seguido de autoclave.

Desta forma, considerando que o pré-tratamento térmico favoreceu a hidrólise e fermentação do BCA, uma vez que maior valor de produção de hidrogênio $(3,79 \mathrm{mmol} / \mathrm{L})$ e velocidade de produção de hidrogênio (20,72 mmol/L.d) foram verificados, optou-se em utilizar o BCA autoclavado como substrato nos reatores em batelada.

\subsection{Produção de hidrogênio e ácidos orgânicos a partir de BCA autoclavado}

A produção biológica de hidrogênio a partir do BCA autoclavado foi estudada a fím de se obter condições ótimas de concentração de substrato e pH. Foram monitorados reatores em batelada com 0,8 até 9,2 g/L de BCA e 4,6 até 7,4 de $\mathrm{pH}$.

Os valores do planejamento fatorial $2^{2}$ para o potencial de produção de hidrogênio $(P)$, velocidade máxima de produção de hidrogênio $(R m)$ e períodos de fase lag $(\lambda)$, ajustados ao modelo de Gompertz modificado estão listados na Tabela 5.2

$\mathrm{O}$ maior valor de produção de hidrogênio $\left(24,06 \mathrm{mmol}_{2} / \mathrm{L}\right)$ foi obtido para as condições do reator $\mathrm{R} 4$ (8,0 g/L de BCA e pH 7,0). A velocidade de produção de hidrogênio também foi maior nesta condição reacional $(4,57 \mathrm{mmol} / \mathrm{L} . \mathrm{d})$. O menor valor de produção de hidrogênio e velocidade de produção de hidrogênio $(0,33 \mathrm{mmol} / \mathrm{L}$ e $0,028 \mathrm{mmol} / \mathrm{L} . \mathrm{d}$, respectivamente) foram observados em $\mathrm{R} 7(5,0 \mathrm{~g} / \mathrm{L}$ de $\mathrm{BCA}$ e $\mathrm{pH} 4,6)$. 
Tabela 5.2: Valores das variáveis independentes e variáveis resposta do planejamento fatorial dos reatores em batelada.

\begin{tabular}{|c|c|c|c|c|c|c|}
\hline \multicolumn{3}{|c|}{ Variáveis independentes } & \multicolumn{4}{|c|}{ Variáveis resposta } \\
\hline & $\begin{array}{c}\text { BCA } \\
\text { autoclavado } \\
(\mathrm{g} / \mathrm{L})\end{array}$ & $\mathrm{pH}$ & $\begin{array}{c}P \\
\left(\mathrm{mmol} \mathrm{H}_{2} / \mathrm{L}\right)\end{array}$ & $\begin{array}{c}R m \\
\left(\mathrm{mmol} \mathrm{H}_{2} / \mathrm{L} . \mathrm{d}\right)\end{array}$ & $\begin{array}{l}\lambda \\
\text { (d) }\end{array}$ & $\mathrm{R}^{2}$ \\
\hline $\mathrm{R} 1$ & 2,0 & 5,0 & $1,64 \pm 0,27$ & $0,41 \pm 0,08$ & $0,2 \pm 0,31$ & 0,97 \\
\hline $\mathrm{R} 2$ & 2,0 & 7,0 & $12,79 \pm 2,10$ & $1,74 \pm 0,28$ & $3,8 \pm 0,52$ & 0,99 \\
\hline $\mathrm{R} 3$ & 8,0 & 5,0 & $7,31 \pm 0,88$ & $0,59 \pm 0,11$ & $1,1 \pm 0,75$ & 0,98 \\
\hline $\mathrm{R} 4$ & 8,0 & 7,0 & $24,06 \pm 1,07$ & $4,57 \pm 1,28$ & $2,7 \pm 0,36$ & 0,99 \\
\hline R5 & 0,8 & 6,0 & $6,79 \pm 1,28$ & $0,64 \pm 0,20$ & $0,2 \pm 0,79$ & 0,98 \\
\hline R6 & 9,2 & 6,0 & $13,64 \pm 2,10$ & $2,18 \pm 0,46$ & $2,0 \pm 0,23$ & 0,98 \\
\hline $\mathrm{R} 7$ & 5,0 & 4,6 & $0,33 \pm 0,01$ & $0,028 \pm 0,06$ & $0 \pm 0,70$ & 0,95 \\
\hline $\mathrm{R} 8$ & 5,0 & 7,4 & $20,13 \pm 1,09$ & $2,31 \pm 0,74$ & $2,1 \pm 0,84$ & 0,97 \\
\hline R9 & 5,0 & 6,0 & $17,86 \pm 2,03$ & $2,79 \pm 0,49$ & $1,5 \pm 0,74$ & 0,99 \\
\hline $\mathrm{R} 10$ & 5,0 & 6,0 & $18,86 \pm 1,34$ & $2,30 \pm 0,26$ & $2,4 \pm 0,74$ & 0,99 \\
\hline
\end{tabular}

Pode-se observar que houve produção de hidrogênio a partir de BCA autoclavado em todos os reatores (R1 a R10) com diferentes concentrações de substrato e pH (Figura 5.4). 


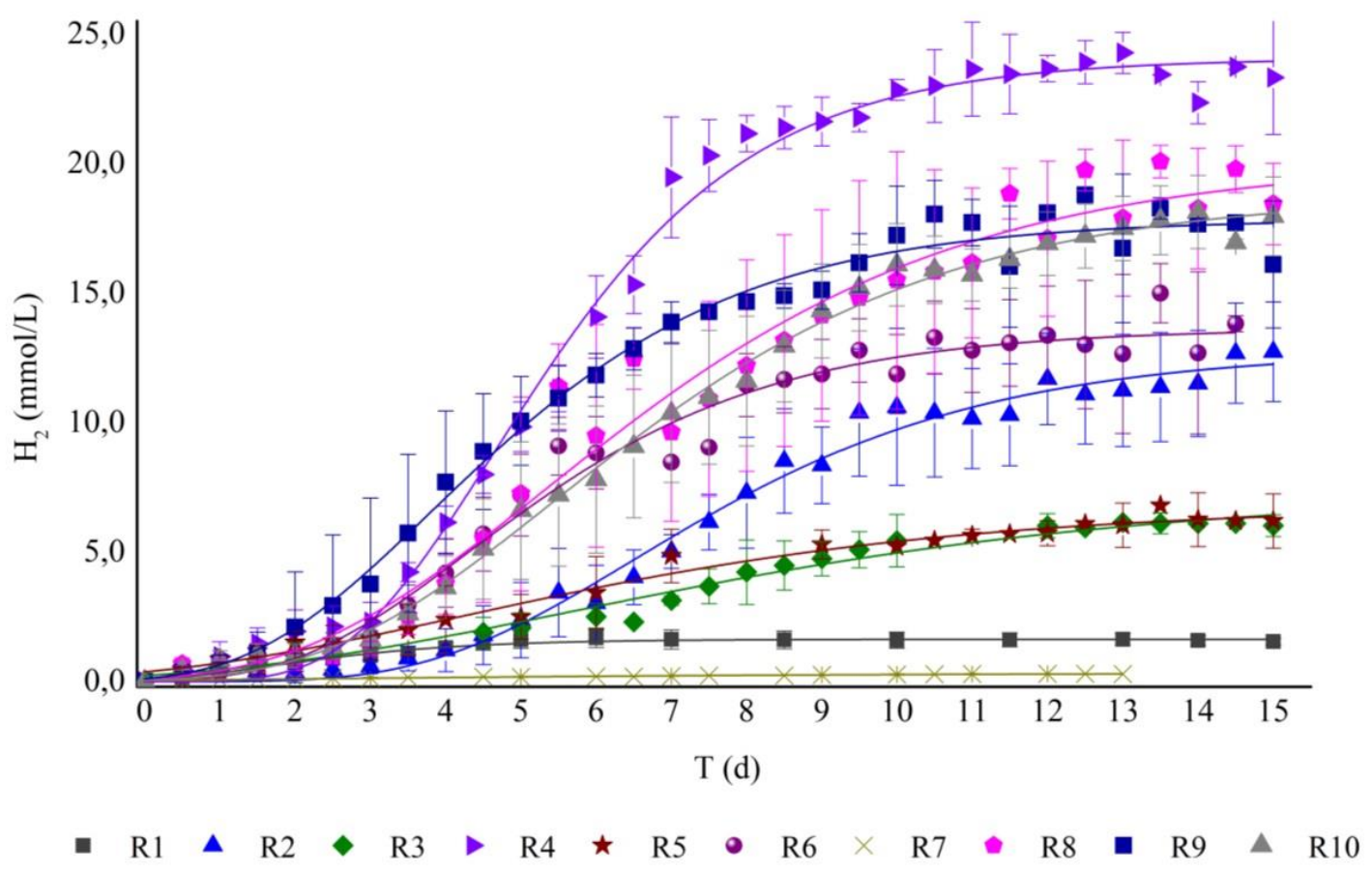

Figura 5.4: Produção de hidrogênio (mmol/L) a partir do BCA em função do tempo nos reatores em batelada do planejamento fatorial: $\mathrm{R1}(2,0 \mathrm{~g} \mathrm{BCA} / \mathrm{L} \mathrm{e} \mathrm{pH} \mathrm{5,0),} \mathrm{R2} \mathrm{(2,0} \mathrm{g} \mathrm{BCA/L} \mathrm{e} \mathrm{pH} \mathrm{7,0),} \mathrm{R3} \mathrm{(8,0} \mathrm{g}$ BCA/L e pH 5,0), R4 (8,0 g BCA/L e pH 7,0), R5 (0,8 g BCA/L e pH 6,0), R6 (9,2 g BCA/L e pH 6,0), R7 $(5,0 \mathrm{~g} \mathrm{BCA} / \mathrm{L}$ e pH 4,6), R8 (5,0 g BCA/L e pH 7,4), R9 e R10 (5,0 g BCA/L e pH 6,0).

A variação na produção de hidrogênio, $P$, (de 0,33 a 24,06 mmol/L em R7 e R4, respectivamente) pode ter sido resultado da interação concentração de substrato e pH. Durante a produção de hidrogênio, ou de outros biocombustíveis, o metabolismo das bactérias celulolíticas é altamente dinâmico e exclusivo para cada espécie. O rendimento do produto final depende de numerosos fatores, entre eles a concentração do substrato e pH (Petitdemange et al., 1992; Bundhoo and Mohee, 2016).

No presente estudo verificou-se para 2,0 g BCA/L aumento de 1,64 para 12,79 mmol/L em pH 5,0 (R1) e 7,0 e (R2), respectivamente. Na condição com 5,0 g BCA/L observou-se 0,33, 17,86, 18,86 e 20,13 mmol $\mathrm{H}_{2} / \mathrm{L}$ em pH 4,6 (R7), 6,0 (R9 e R10) e 7,4 (R8), respectivamente. O mesmo perfil foi obtido com 8,0 g BCA/L, ou seja, observou-se aumentou de 7,31 para 24,06 mmol/L em pH 5,0 (R3) e 7,0 (R4), respectivamente.

Assim, é notável destacar que para maiores valores de $\mathrm{pH}$ obteve-se maior produção de hidrogênio. Por exemplo, foi observado para valores de $\mathrm{pH}$ próximos a 7,0 (7,0 em R4 e 7,4 em R8) maiores valores de produção de hidrogênio (24,06 e 20,13 mmol/L, respectivamente). Este relato foi consistente com os resultados de Lin e Hung (2008), que avaliaram o efeito do $\mathrm{pH}($ de 5,5 a 9,0) na produção de hidrogênio a partir de celulose por 
consórcio microbiano de esterco bovino enriquecido sob condições termofílicas $\left(55^{\circ} \mathrm{C}\right)$. Segundo esses autores, a maior produção de hidrogênio $(31,25 \mathrm{mmol} / \mathrm{L})$ foi obtida em pH 7,0.

Fangkum e Reungsang (2011) estudaram, separadamente, os efeitos da concentração de substrato e pH na produção de hidrogênio por cultura mista de fezes de elefante pré-tratada como inóculo e hidrolisado de BCA como substrato. De acordo com estes autores, o pH 6,5 e $10,0 \mathrm{~g} / \mathrm{L}$ de açúcares totais do BCA hidrolisado foram as melhores condições para produção de hidrogênio (58,7 mmol/L). Pattra et al. (2008) estudaram os efeitos do pH na produção de hidrogênio por Clostridium butyricum e hidrolisado de BCA como substrato. Os autores relataram que condição com pH 5,5 foi a melhor para produção de hidrogênio de $530 \mathrm{mmol} / \mathrm{L}$ a $37^{\circ} \mathrm{C}$. Fan et al. (2006) também avaliaram o efeito do $\mathrm{pH}(4,0$ a 6,0$)$ na produção de hidrogênio a partir de palha de trigo pré-tratada e cultura pré-tratada de esterco de gado como inóculo. Os autores observaram influência significativa das condições de $\mathrm{pH}$ na produção de hidrogênio e, com o aumento do $\mathrm{pH}$ de 4,0 para 7,0, a produção de hidrogênio aumentou de 0,01 para 24,1 $\mathrm{mL} \mathrm{H}_{2} / \mathrm{g}$ STV. No entanto, verificaram diminuição para $22,7 \mathrm{~mL} \mathrm{H}_{2} / \mathrm{g}$ STV com o aumento do $\mathrm{pH}$ para 9,0 .

Portanto, $\mathrm{pH}$ é um dos principais fatores que afetam a produção de hidrogênio a partir de substratos celulósicos. Baixos valores de $\mathrm{pH}$ podem afetar a hidrólise do substrato, a atividade da hidrogenase, assim como a via metabólica, ocasionando decréscimo na produção de hidrogênio (Zhang et al., 2003; Liu e Shen, 2004; Wang e Wan, 2009). No presente estudo, verificou-se que a condição de pH 4,6 não foi favorável à produção de hidrogênio, uma vez que a menor produção de hidrogênio $(0,33 \mathrm{mmol} / \mathrm{L})$ foi observada no reator $\mathrm{R} 7$.

Lin e Hung (2008) não verificaram produção de hidrogênio em pH 5,5. Os autores relacionaram este resultado com as características inerentes ao inóculo utilizado, ou seja, $\mathrm{pH}$ 5,5 não foi favorável para as bactérias produtoras de hidrogênio do esterco bovino. No presente estudo, as condições de $\mathrm{pH}$ ácido $(4,6)$ não foram adequadas para as bactérias celulolíticas e fermentativas produtoras de hidrogênio oriundas do consórcio anaeróbio e autóctones do BCA.

Em relação à concentração de substrato, este fator pode afetar, principalmente, o crescimento de bactérias celulolíticas. Para o crescimento em substratos celulósicos, inicialmente as bactérias têm que aderir ao substrato para, então, hidrolisá-lo em açúcares solúveis (Desvaux et al., 2000). Desta forma, a limitação de substrato pode implicar em ineficiente hidrólise por causa da limitada acessibilidade ao substrato. Por outro lado, grande quantidade de substrato celulósico pode favorecer a hidrólise e disponibilizar excesso de 
açúcares solúveis no meio. O excesso de produtos da hidrólise como, por exemplo, a celobiose pode ocasionar inibição pelo produto, o que pode inibir tanto o crescimento bacteriano quanto a produção de celulases e, consequentemente, comprometer o rendimento do produto final (Petitdemange et al., 1992; Desvaux et al., 2000; Guedon et al., 2000; Desvaux, 2005; Levin et al., 2009).

Ren et al. (2010) avaliaram o efeito da concentração de celulose (de 5,0 a 25,0 g/L) em reatores em batelada inoculados com esterco bovino, em $\mathrm{pH} 6,8$. Os autores relataram que a produção de hidrogênio aumentou de 284,3 para 429,6 mmol/L, para 5,0 a 10,0 g/L de celulose, respectivamente. Tendência semelhante foi observada no presente estudo, ou seja, verificou-se aumento da produção de hidrogênio de 12,79 para 24,06 mmol/L para 2,0 a 8,0 $\mathrm{g} / \mathrm{L}$ de BCA, em pH 7,0 (R2 e R4, respectivamente). Sob as condições de maior concentração de BCA (8,0 g/L em R4), provavelmente, ocorreu a acessibilidade ao carbono e aderência ao substrato pelas bactérias e, consequentemente, maior produção de hidrogênio.

Da mesma forma, verificou-se para os reatores com pH 6,0 aumento da produção de hidrogênio de 6,79 para 17,86 e 18,87 mmol/L utilizando 0,8 (R5) e 5,0 g BCA/L (R9 e R10), respectivamente. Entretanto, em mesmo pH $(6,0)$, quando a concentração do substrato foi aumentada para 9,2 g/L (R6), a produção de hidrogênio diminuiu para 13,64 mmol/L. Assim como no presente estudo, Pattra et al (2008) relataram diminuição na produção de hidrogênio de 8,03 para $6,70 \mathrm{mmol} / \mathrm{L}$, quando foi aumentada a concentração de hidrolisado de BCA de 20,0 para 40,0 g DQO/L em reatores em batelada inoculados com Clostridium butyricum. Assim, a concentração do substrato pode afetar positivamente a produção de metabólitos até certo ponto e então pode ter efeito negativo (Desvaux et al., 2000). No presente estudo, a maior concentração de substrato $(9,2$ g BCA/L), provavelmente, favoreceu maior liberação de açúcares solúveis, os quais inibiram o crescimento celular e atividade da celulase; comprometendo os rendimentos dos produtos finais, sob tais condições a produção de hidrogênio foi de 13,64 mmol/L.

Os maiores valores de produção molar de hidrogênio relatados na literatura foram obtidos a partir da parte líquida (hidrolisado) obtida após o pré-tratamento do BCA. Com a fração sólida do BCA, os valores de produção molar de hidrogênio obtidos no presente estudo foram superiores àqueles relatados por Ratti et al. (2015) e Soares et al (2017 (Tabela 5.3). 
Tabela 5.3: Produção de hidrogênio a partir de BCA

\begin{tabular}{|c|c|c|c|c|}
\hline Referência & Substrato & Inóculo & Condições & $\begin{array}{c}\mathrm{P} \\
\left(\mathrm{mmol} \mathrm{H}_{2} / \mathrm{L}\right)\end{array}$ \\
\hline $\begin{array}{l}\text { Pattra et al. } \\
\qquad(2008)\end{array}$ & $\begin{array}{l}\text { Hidrolisado do } \\
\text { BCA }\end{array}$ & $\begin{array}{l}\text { Clostridium } \\
\text { butyricum }\end{array}$ & $\begin{array}{c}\text { pH 5,5 concentração } \\
\text { de açúcares: } 20 \mathrm{~g} \\
\text { DQO/L }\end{array}$ & 530,0 \\
\hline $\begin{array}{c}\text { Fangkum e } \\
\text { Reungsang (2011) }\end{array}$ & $\begin{array}{l}\text { Hidrolisado de } \\
\text { BCA }\end{array}$ & $\begin{array}{c}\text { Esterco pré-tratado } \\
\text { de elefante }\end{array}$ & $\begin{array}{l}\text { pH 6,5 concentração } \\
\text { de açúcares: } 10 \text { g/L }\end{array}$ & 58,7 \\
\hline Ratti et al. (2015) & $\begin{array}{l}\text { BCA pré- } \\
\text { tratado }\end{array}$ & $\begin{array}{c}\text { Bactérias autóctones } \\
\text { do BCA }\end{array}$ & $0,5 \mathrm{~g}$ substrato/L & 7,04 \\
\hline $\begin{array}{l}\text { Soares et al. } \\
\qquad(2017)\end{array}$ & $\begin{array}{l}\text { BCA pré- } \\
\text { tratado }\end{array}$ & Lodo de UASB & $\begin{array}{c}3,0 \text { g extrato de } \\
\text { levedura/L } \\
60^{\circ} \mathrm{C}\end{array}$ & 17,7 \\
\hline Presente estudo & $\begin{array}{l}\text { BCA pré- } \\
\text { tratado }\end{array}$ & $\begin{array}{l}\text { Inóculo fermentativo } \\
+ \text { bactérias } \\
\text { autóctones }\end{array}$ & $\begin{array}{c}8,0 \text { g substrato/L } \\
\text { pH 7,0 }\end{array}$ & 24,06 \\
\hline
\end{tabular}

\subsection{Análise estatística do Delineamento Fatorial por Composto Central}

Nessa pesquisa realizou-se análise de delineamento por composto central com a finalidade de avaliar o efeito da concentração de substrato e $\mathrm{pH}$, bem como, a interação entre estas variáveis na produção de hidrogênio nos reatores em batelada. A metodologia de superfície de resposta foi utilizada para avaliar a região ótima de produção de hidrogênio, velocidade de produção de hidrogênio e $\lambda$ a partir do BCA autoclavado.

A partir dos diagramas de Pareto (Figura 5.5) pode-se observar os efeitos padronizados $(t)$ das variáveis concentração de substrato e pH sobre as respostas. Os valores absolutos destes efeitos fornecem as alturas das barras, as quais estão dispostas em ordem decrescente na Figura 5.5. 
A)

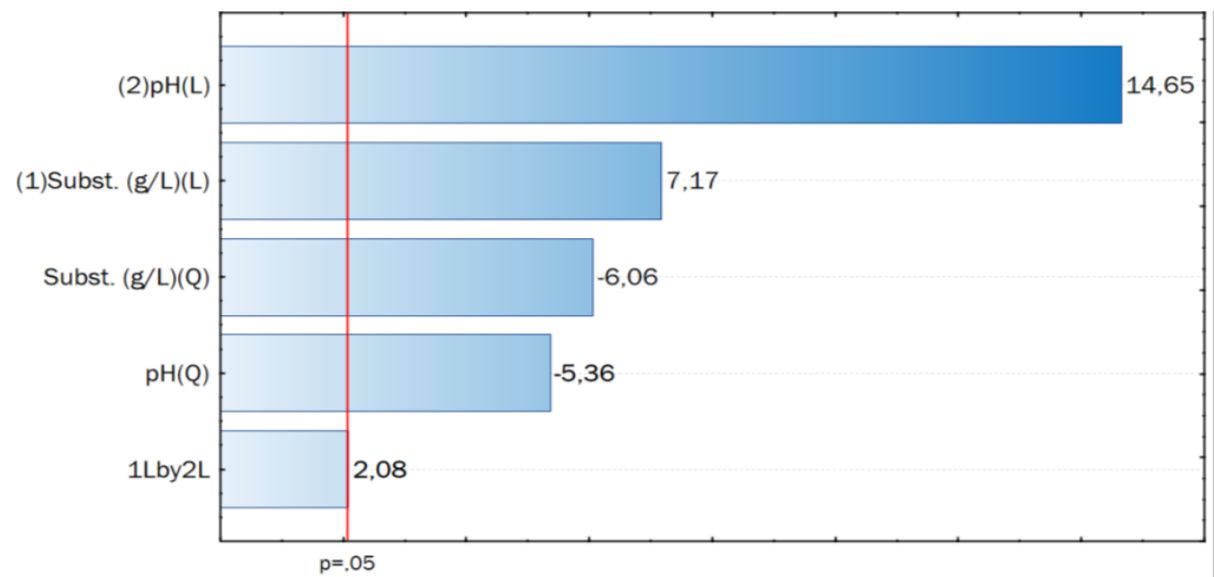

B)

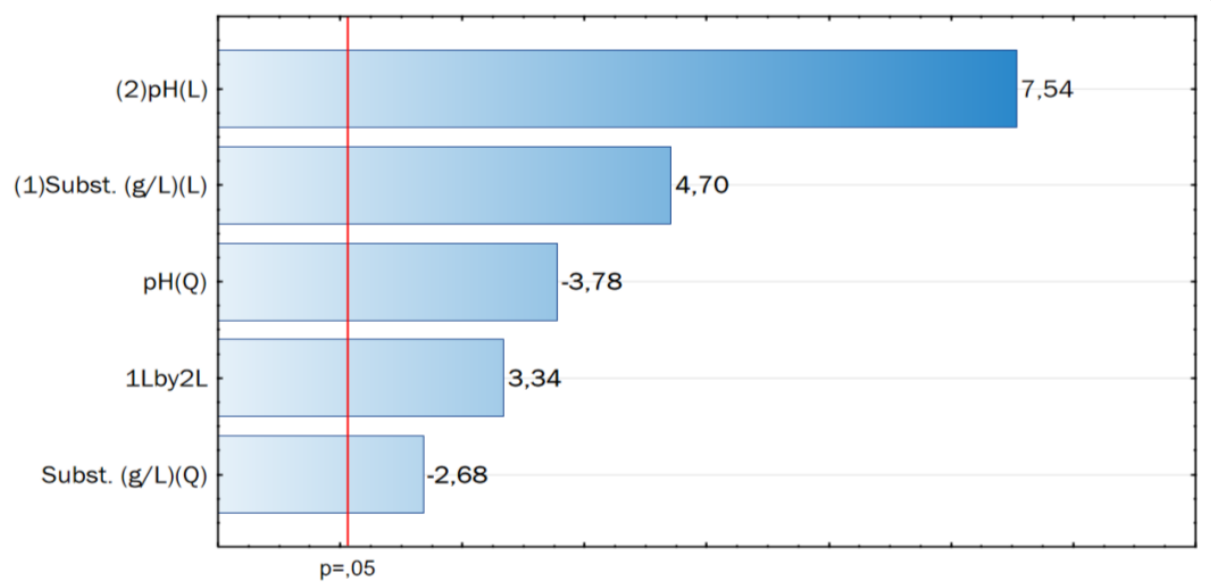

C)

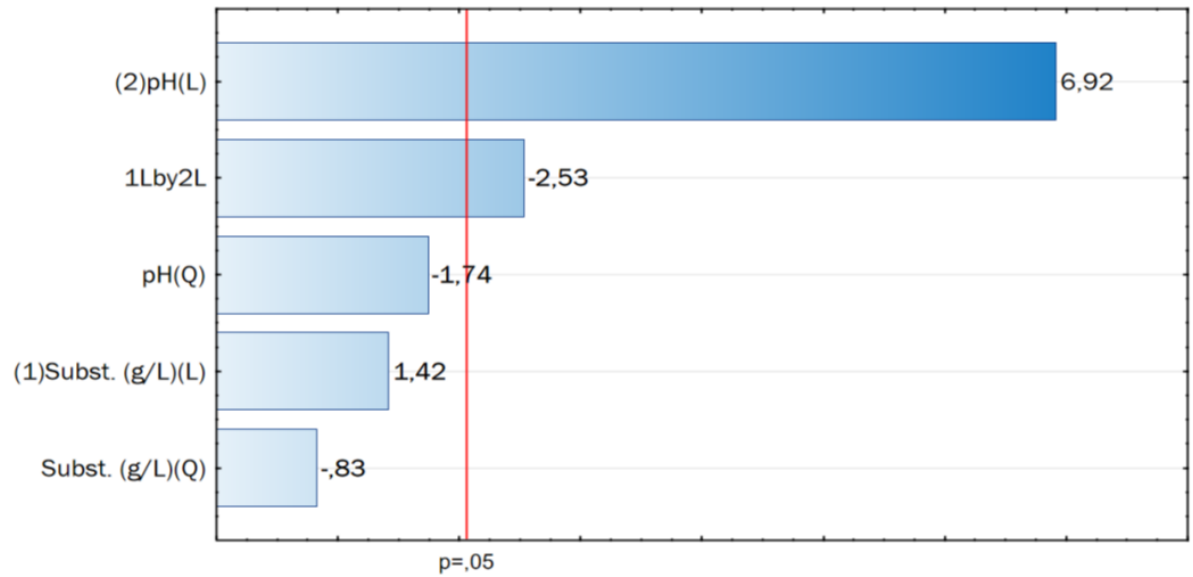

Figura 5.5: Diagramas de Pareto dos efeitos da concentração de substrato e pH na produção máxima de hidrogênio (A), velocidade de produção de hidrogênio (B) e $\lambda$ (C).

L: efeito linear; Q: efeito quadrático e 1Lby2L: efeito da interação entre concentração de substrato e pH

Observou-se para os fatores concentração de substrato e pH e, também a interação entre eles, efeitos significativos sobre as respostas produção e velocidade de produção de hidrogênio. Em relação a resposta $\lambda$ observou-se efeito significativo do $\mathrm{pH}$ (efeito linear) e da interação entre concentração de substrato e pH. Verificou-se que a maior influencia na produção, velocidade de produção de hidrogênio e $\lambda$ foi devido a variável $\mathrm{pH},(95 \%$ de confiança, $\mathrm{p}<0,05)$. 
A Equação 5.1 representa a produção biológica de hidrogênio em função dos efeitos significativos, ou seja, a concentração de substrato e $\mathrm{pH}$, na qual $Y$ representa o valor previsto da produção de hidrogênio $(\mathrm{mmol} / \mathrm{L}), x_{1}$ o valor codificado de concentração de substrato e $x_{2}$ representa o valor codificado de $\mathrm{pH}\left(\mathrm{R}^{2}=0,93\right)$.

$$
Y=17,96+3,38 x_{1}-3,78 x_{1}{ }^{2}+6,91 x_{2}-3,35 x_{2}^{2}+1,39 x_{1} x_{2} \quad \text { Equação } 5.1
$$

Na Equação 5.2 pode-se analisar o modelo polinomial de $2^{\mathrm{a}}$ ordem para a velocidade de produção de hidrogênio $\left(\mathrm{R}^{2}=0,81\right)$, na qual $W$ representa o valor previsto de velocidade de produção de hidrogênio (mmol/L.d), $x_{1}$ o valor codificado de concentração de substrato e $x_{2}$ representa o valor codificado de $\mathrm{pH}$.

$$
\mathrm{W}=3,21+0,76 \mathrm{x}_{1}-0,57 \mathrm{x}_{1}{ }^{2}+1,21 \mathrm{x}_{2}-0,80 \mathrm{x}_{2}{ }^{2}+0,76 \mathrm{x}_{1} \mathrm{x}_{2} \quad \text { Equação } 5.2
$$

Já na Equação 5.3, pode-se analisar o modelo polinomial de $2^{\mathrm{a}}$ ordem para $\lambda$ e as variáveis codificadas e significativas $\left(\mathrm{R}^{2}=0,71\right)$, na qual $Z$ representa o valor previsto de $\lambda, x_{1}$ $\mathrm{o}$ valor codificado de concentração de substrato e $x_{2}$ representa o valor codificado de $\mathrm{pH}$.

$$
\mathrm{Z}=2,42+1,14 \mathrm{x}_{2}-0,59 \mathrm{x}_{1} \mathrm{x}_{2}
$$

\section{Equação 5.3}

A adequação dos modelos foi verificada por análise de variância (ANOVA) confirmando que os modelos obtidos com os dados do planejamento fatorial representam o delineamento composto central (Tabela 5.4). 
Tabela 5.4: Teste ANOVA para os efeitos da concentração de substrato e pH das variáveis de produção, velocidade de produção de hidrogênio e $\lambda$.

\begin{tabular}{|c|c|c|c|c|c|c|}
\hline Resposta & $\begin{array}{c}\text { Fontes de } \\
\text { variação }\end{array}$ & $\begin{array}{l}\text { Soma de } \\
\text { quadrados }\end{array}$ & $\begin{array}{c}\text { Grau de } \\
\text { Liberdade }\end{array}$ & $\begin{array}{l}\text { Quadrados } \\
\text { médios }\end{array}$ & Fcalculado & Ftabelado \\
\hline \multirow{5}{*}{$\begin{array}{l}\text { Produção de } \\
\text { hidrogênio } \\
\left(\mathrm{mmol}_{2} / \mathrm{L}\right)\end{array}$} & Regressão & $1.793,61$ & 5 & 358,72 & 67,18 & 2,62 \\
\hline & Resíduo & 128,16 & 24 & 5,34 & & \\
\hline & $\begin{array}{c}\text { Falta de } \\
\text { ajuste }\end{array}$ & 57,20 & 3 & 19,07 & & \\
\hline & Erro puro & 70,95 & 21 & 3,38 & & \\
\hline & Total & $1.921,77$ & 29 & 364,06 & & \\
\hline \multirow{5}{*}{$\begin{array}{l}\text { Velocidade } \\
\text { de produção } \\
\text { de } \\
\text { hidrogênio } \\
\text { (mmol } \\
\left.\mathrm{H}_{2} / \mathrm{L} . \mathrm{d}\right)\end{array}$} & Regressão & 69,43 & 5 & 13,88 & 22,30 & 2,62 \\
\hline & Resíduo & 14,94 & 24 & 0,62 & & \\
\hline & $\begin{array}{l}\text { Falta de } \\
\text { ajuste }\end{array}$ & 3,07 & 3 & 1,02 & & \\
\hline & Erro puro & 11,87 & 21 & 0,56 & & \\
\hline & Total & 80,75 & 29 & 14,51 & & \\
\hline \multirow{5}{*}{$\begin{array}{l}\lambda \\
\text { (d) }\end{array}$} & Regressão* & 35,55 & 2 & 17,77 & 24,03 & 2,62 \\
\hline & Resíduo* & 19,48 & 27 & 0,72 & & \\
\hline & $\begin{array}{c}\text { Falta de } \\
\text { ajuste }\end{array}$ & 1,35 & 3 & 0,45 & & \\
\hline & Erro puro & 14,37 & 21 & 0,68 & & \\
\hline & Total & 55,03 & 29 & 14,51 & & \\
\hline
\end{tabular}

*Os efeitos não significativos para a resposta $\lambda$ foram considerados como informação não modelada (resíduo).

A partir do teste ANOVA, valores de Fcalculado foram bem maiores em relação aqueles valores de Ftabelado, logo, obtiveram-se quadrados médios de regressão $(358,72$, 13,88 e 17,77 para $P, R m$ e $\lambda$, respectivamente) e resíduo (5,34, 0,62 e 0,72 para $P, R m$ e $\lambda$, respectivamente) estatisticamente diferentes.

Desta forma, a partir dos modelos significativos obtiveram-se as superfícies de resposta e curvas de contorno para produção de hidrogênio (Figuras 5.6 A e B), velocidade de produção 
de hidrogênio (Figura 5.7 A e B) e $\lambda$ (Figura 5.8 A e B). O ponto ótimo para cada variável resposta pode ser verificada no pico formado na superfície de cada gráfico.

Pode-se observar, tanto na superfície de resposta, quanto nas curvas de contorno (Figuras 5.6 $\mathrm{A}$ e B), que a produção de hidrogênio foi mais sensível à variação do $\mathrm{pH}$ em relação a concentração de substrato, fato esse já observado pelo gráfico de Pareto (Figura 5.5). Observou-se que as regiões de máxima produção de hidrogênio situam-se em pH acima de 6,0 e, para concentração de substrato, acima de 4,0 g/L. Em relação a resposta velocidade de produção de hidrogênio observou-se que a região ótima foi para $\mathrm{pH}$ acima de 6,0 e concentração de substrato acima de 4,5 g/L (Figura 5.7 A e B).

A)

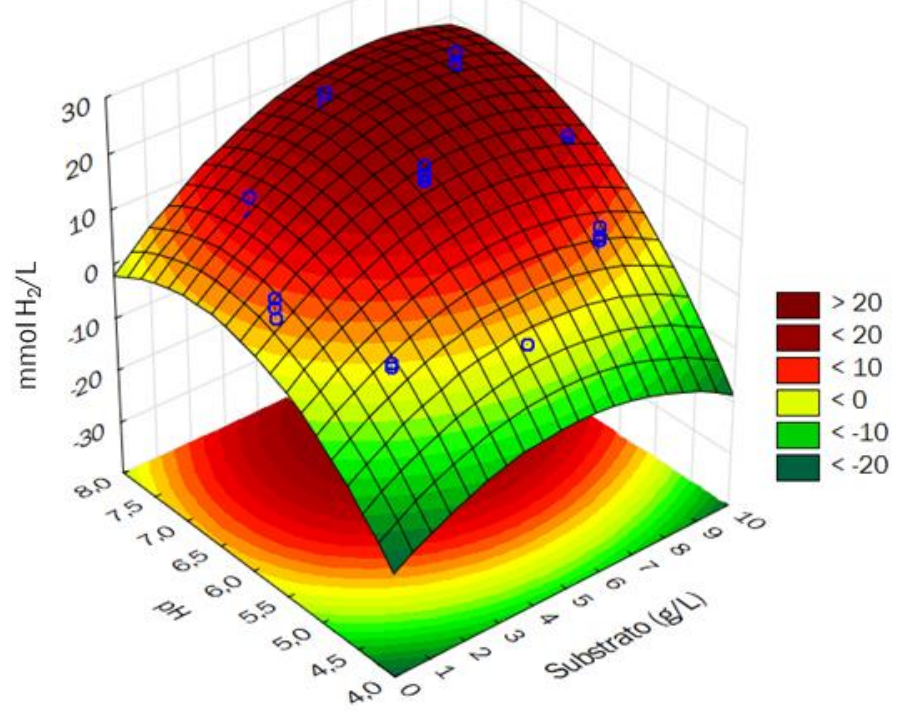

B)

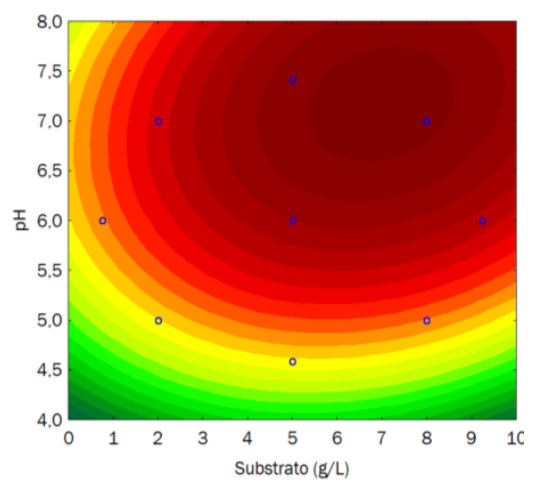

Figura 5.6: Superfície de resposta (A) e Curvas de contorno (B) para produção de hidrogênio $(\mathbf{m m o l} / \mathbf{L})$. 


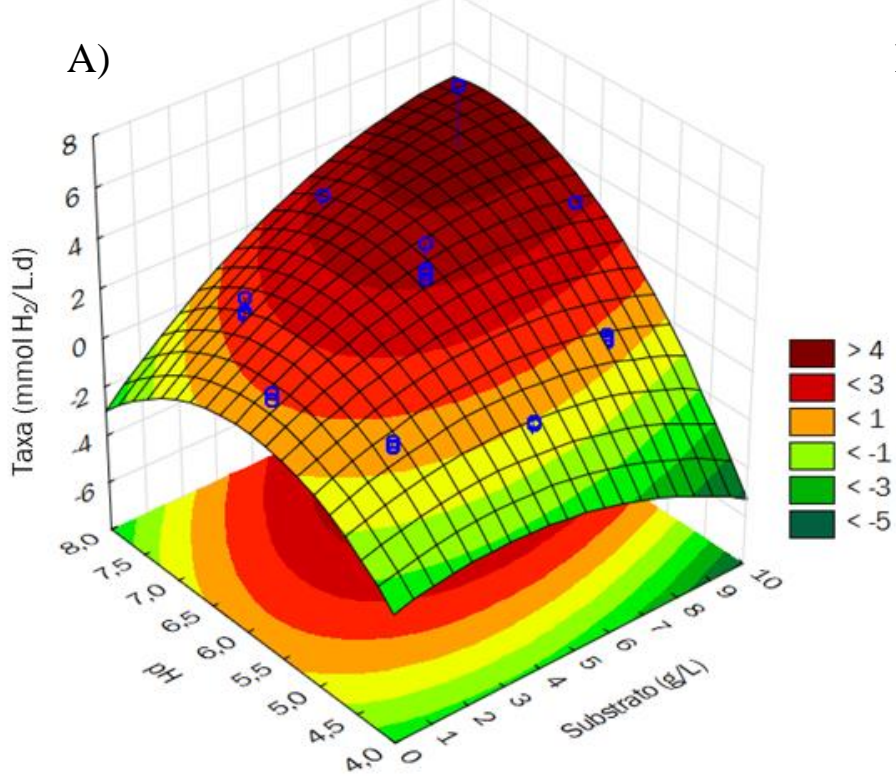

B)

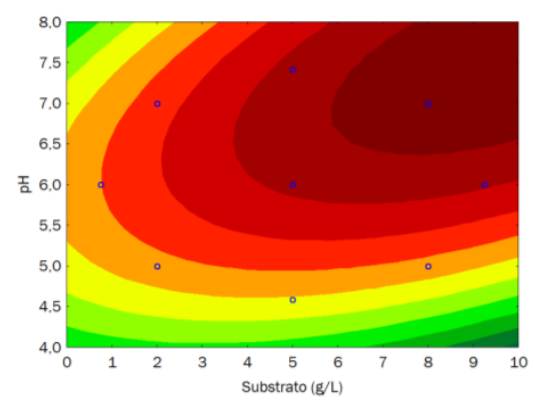

Figura 5.7: Superfície de resposta (A) e curvas de contorno (B) para velocidade de produção de hidrogênio (mmol/L.d).

Em relação a $\lambda$ (Figura 5.8), que representa o início da produção de hidrogênio, menores valores são mais interessantes para o sistema, uma vez que a produção de hidrogênio começa mais rapidamente. Então, pode-se inferir que as condições de pH abaixo de 5,5 foram as que mais favoreceram menores $\lambda$ (com menos de 1 dia). Entretanto, sob tais condições de $\mathrm{pH}$, a produção e velocidade de produção de hidrogênio não foram favoráveis. Desta forma, $\lambda$ não foi uma resposta considerado para a otimização do processo de produção de hidrogênio a partir de BCA autoclavado. 


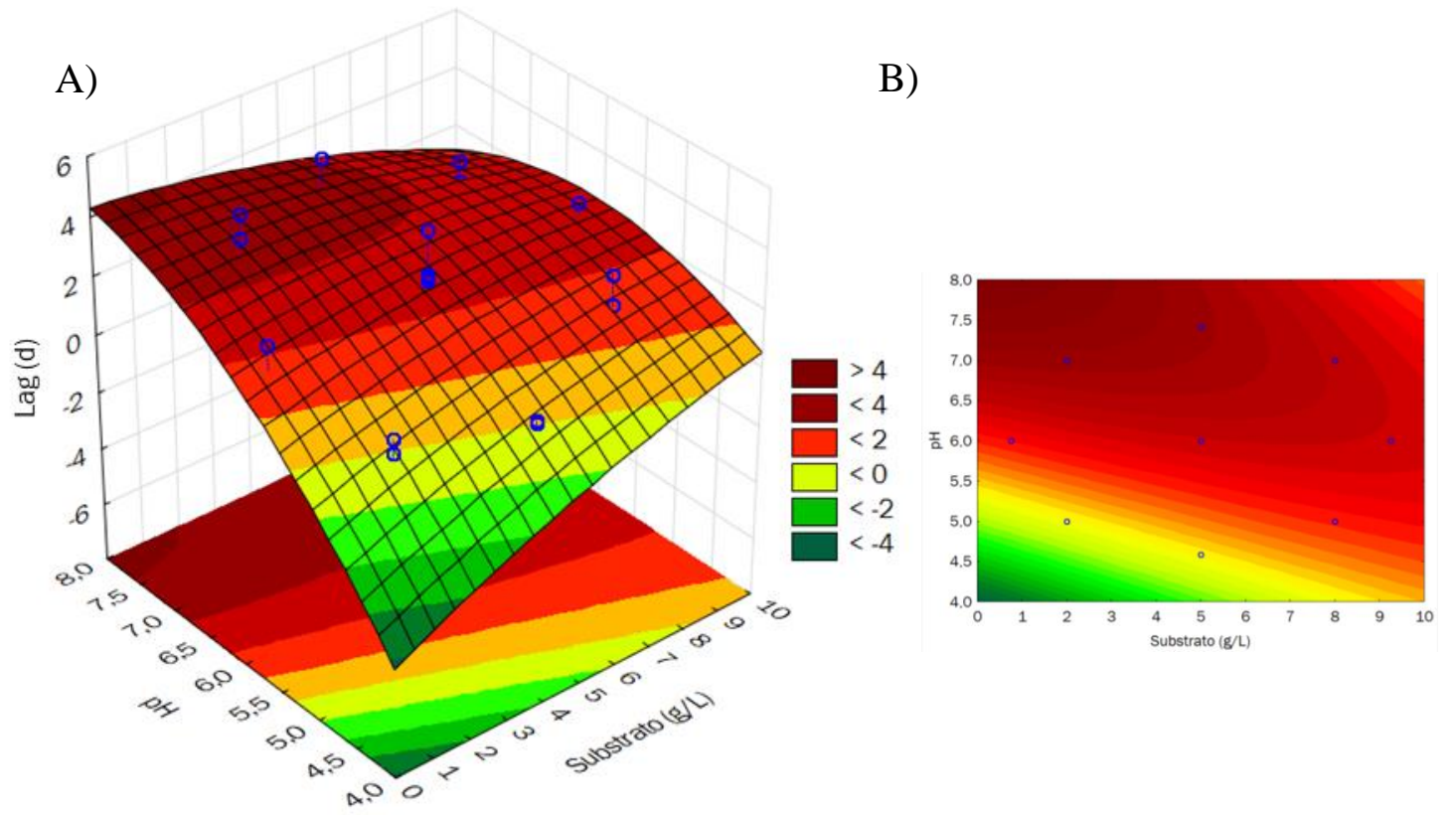

Figura 5.8: Superfície de resposta (A) e curvas de contorno (B) para $\lambda$ (d).

Assim, a partir dos resultados obtidos com o planejamento fatorial, foi possível verificar que o valor máximo de produção de hidrogênio estimado pelo modelo foi 23,10 $\mathrm{mmol} / \mathrm{L}$, com concentração de substrato de 7,0 g/L e pH 7,2. Em relação ao valor máximo de velocidade de produção obteve-se 4,8 mmol/L.d, para 10,1 g BCA/L e pH 7,6.

A validação do modelo foi realizada com os fatores estipulados para a produção de hidrogênio, descrito em Validação do modelo de produção de hidrogênio.

\subsubsection{Metabólitos solúveis}

\subsubsection{Matéria Orgânica}

O uso de substrato insolúvel, como o BCA, não contribuiu com a DQO solúvel inicial do meio reacional, pode-se observar, desta forma, valores de DQO no início dos experimentos de 0,5 até 1,9 g DQO/L. A partir da hidrólise e fermentação do BCA observou-se a formação de matéria carbonácea solúvel e relacionada a açúcares, ácidos orgânicos e álcoois, por conseguinte valores crescentes de matéria orgânica expressa em DQO (Figura 5.9). 


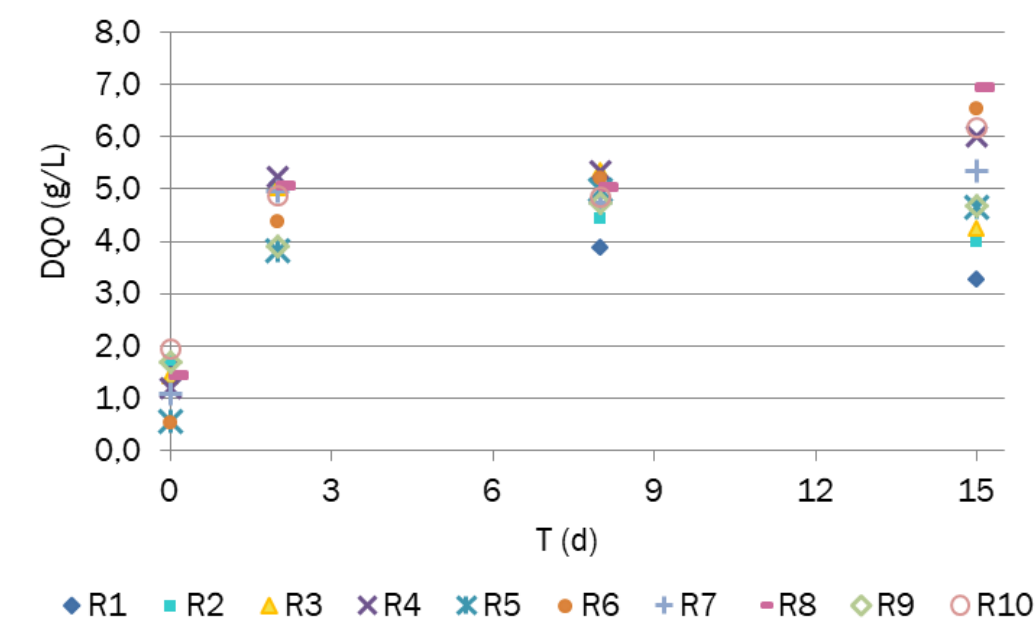

Figura 5.9: DQO solúvel nos reatores do planejamento: $R 1(2,0 \mathrm{~g}$ BCA/L e pH 5,0), $R 2(2,0 \mathrm{~g}$ BCA/L e pH 7,0), R3 (8,0 g BCA/L e pH 5,0), R4 (8,0 g BCA/L e pH 7,0), R5 (0,8 g BCA/L e pH 6,0), R6 $(9,2$ g BCA/L e pH 6,0), R7 (5,0 g BCA/L e pH 4,6), R8 (5,0 g BCA/L e pH 7,4), R9 e R10 (5,0 g BCA/L e pH 6,0).

Por meio da DQO analisam-se, indiretamente, os equivalentes redutores (elementos reduzidos) das amostras finais de cada reator. A DQO-equivalente determinada de acordo com os coeficientes de conversão e cada produto é importante para averiguar a contribuição relativa desses compostos em relação a DQO (Aquino et al., 2006). Pode-se observar que o aumento da concentração de DQO final nos experimentos foi, principalmente, devido aos ácidos orgânicos, visto que mais de $80 \%$ da DQO-equivalente foi referente a estes metabólitos (Figura 5.10).

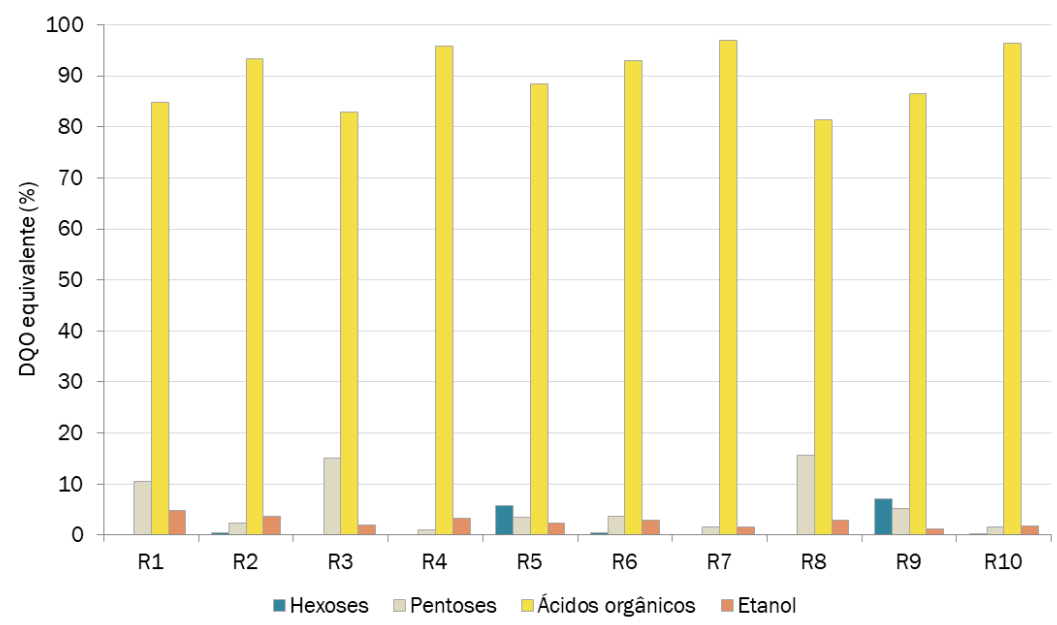

Figura 5.10: DQO-equivalente $(\%)$ dos principais metabólitos solúveis produzidos nas amostras finais dos reatores $\mathrm{R} 1(2,0 \mathrm{~g} \mathrm{BCA} / \mathrm{L}$ e pH 5,0), $\mathrm{R2}(2,0 \mathrm{~g} \mathrm{BCA} / \mathrm{L}$ e pH 7,0), $\mathrm{R3}(8,0 \mathrm{~g}$ BCA/L e pH 5,0), R4 $(8,0$ g BCA/L e pH 7,0), R5 (0,8 g BCA/L e pH 6,0), R6 (9,2 g BCA/L e pH 6,0), R7 (5,0 g BCA/L e pH 4,6), R8 (5,0 g BCA/L e pH 7,4), R9 e R10 (5,0 g BCA/L e pH 6,0). 


\subsubsection{Açúcares solúveis}

Os açúcares da fase líquida têm sido monitorados, principalmente, para verificar as adequações das condições de pré-tratamentos físico-químicos para os substratos lignocelulósicos, uma vez que quanto maior a quantidade de açúcar, mais adequado é o prétratamento (Kim e Holtzapple, 2005; Kabel et al., 2007; Li et al., 2011; Candido et al., 2012; Arreola-Vargas et al., 2013).

Análises de açúcares solúveis ao longo do período de incubação dos reatores em batelada não têm sido relatadas na literatura e representa um dos objetivos deste estudo. Neste caso, como a conversão de substratos lignocelulósicos em açúcares solúveis é um dos fatores limitantes da hidrólise e fermentação (Desvaux et al., 2000), o aumento da concentração destes açúcares na fase líquida pode ser um bom indicativo da hidrólise do substrato em reatores em batelada.

O BCA contém açúcares polimerizados em celulose e hemicelulose, os quais podem ser convertidos em hidrogênio e ácidos orgânicos. Uma vez que a celulose é um polímero de glicose, e a hemicelulose consiste em xilose, arabinose, glicose, galactose e manose (Kumar et al., 2008), pode-se inferir que esses açúcares na fase líquida indicam indiretamente o metabolismo de bactérias celulolíticas (Lin e Hung, 2008).

Pode-se observar na Figura 5.11, concentrações variadas de manose, galactose, xilose e arabinose ao longo do tempo. 

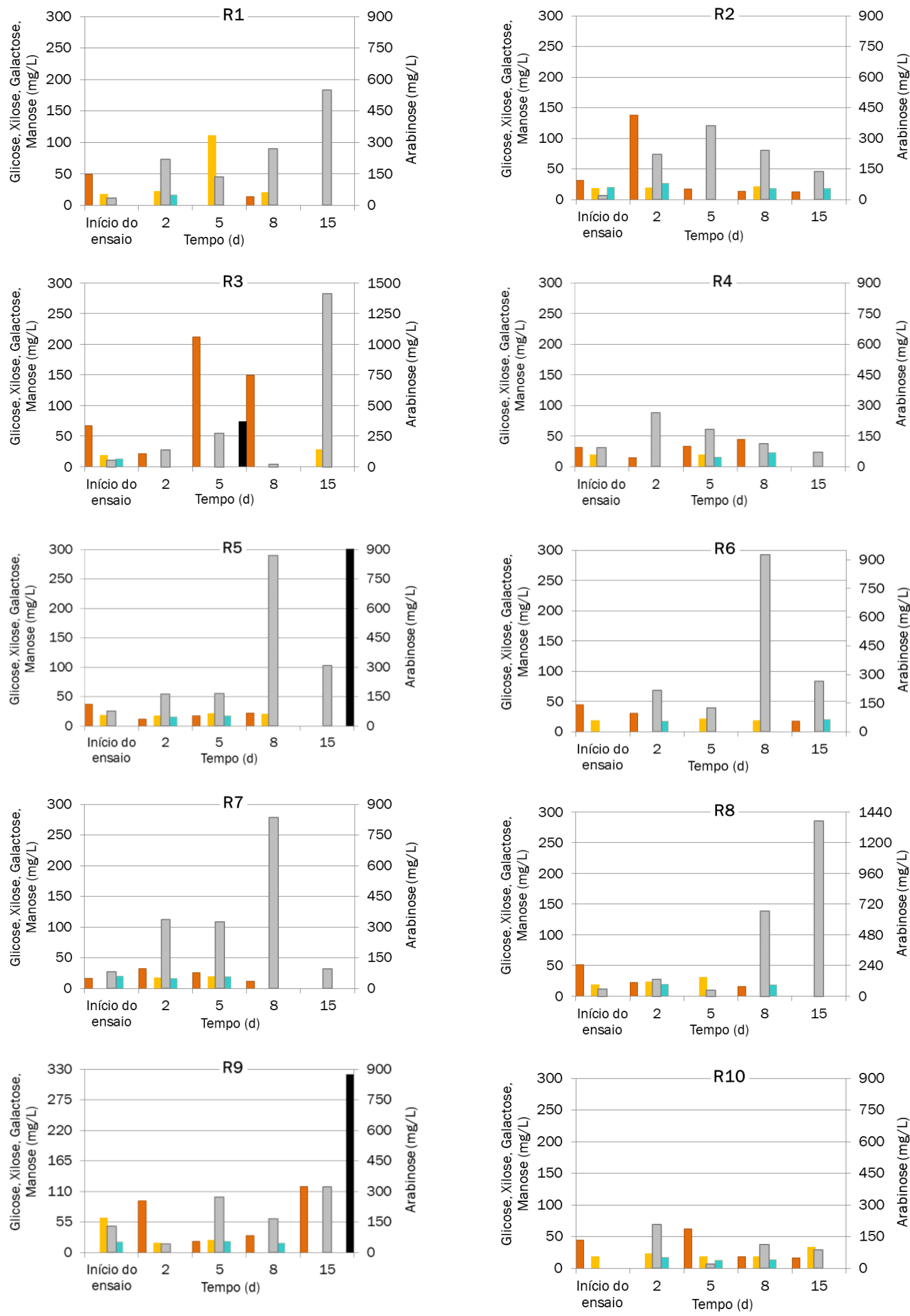

Glicose $\quad$ Xilose Galactose

- Manose $\square$ Arabinose

Figura 5.11: Perfil de açúcares solúveis nos reatores do planejamento fatorial: R1 (2,0 g BCA/L e pH 5,0), R2 (2,0 g BCA/L e pH 7,0), R3 (8,0 g BCA/L e pH 5,0), R4 (8,0 g BCA/L e pH 7,0), R5 (0,8 g BCA/L e pH 6,0), R6 (9,2 g BCA/L e pH 6,0), R7 (5,0 g BCA/L e pH 4,6), R8 (5,0 g BCA/L e pH 7,4), R9 e R10 (5,0 g BCA/L e pH 6,0). 
Glicose, xilose e galactose foram observadas ao longo do tempo em todos os reatores. As maiores concentrações de açúcares observadas foram de 212,04, 110,92 e 23,45 mg/L em R3, R1 e R4, respectivamente. Manose foi observada apenas em R3, R5 e R9, respectivamente 73,47, 502,86 e 302,57 mg/L. Arabinose foi o açúcar observado em maior concentração nos reatores R3 e R8, respectivamente, 1.415,26 e 1.372,45 mg/L (Figura 5.11).

Em R4 (8,0 g BCA/L e pH 7,0) foi observada a menor concentração de açúcares na fase líquida $(278,3,252,6,181,6$ e 70,5 mg/L em 2, 5, 8 e 15 dias, respectivamente), maior produção de hidrogênio $\left(24,06 \mathrm{mmol} \mathrm{H}_{2} / \mathrm{L}\right)$ e maior concentração de ácidos orgânicos ao final do experimento (6,42 g/L). Além disso, na análise comparativa das condições de R4 e R2 (pH 7,0), pode-se observar diminuição da concentração de açúcares na fase líquida ao longo do tempo de incubação. A conversão dos açúcares foi maior em R4 (72,1\%), para maior concentração inicial de BCA autoclavado (8,0 g/L), em relação ao R2 $(55,7 \%)$ com 2,0 BCA g/L. A maior eficiência de conversão relatada em R4 resultou em maior produção de hidrogênio (24,06 mmol/L) e ácidos orgânicos (6,42 g/L) do que R2 (12,72 mmol H $2 / \mathrm{L} \mathrm{e} \mathrm{4,91}$ g ácidos orgânicos/L).

Nas condições do reator com pH 4,6 (R7), observou-se que a maior concentração de açúcares foi liberada no início do experimento $(403,4 \mathrm{mg} / \mathrm{L} \mathrm{em} 2$ dias), quando comparada aos reatores com pH 6,0, 6,0 e 7,4 (154,6, 247,5 e 200,5 mg/L em R9, R10 e R8, respectivamente) no mesmo período e mesma concentração de BCA (5,0 g/L). Provavelmente, a maior liberação inicial de açúcares no meio líquido pode, também, ter favorecido a rápida produção de hidrogênio em R7, uma vez que nesta condição foi observado o menor valor de $\lambda$ (menos de um dia).

Em relação à condição de pH 6,0, (R5, R6, R9 e R10, com 0,8, 9,2, 5,0 e 5,0 g BCA/L, respectivamente) verificou-se aumento e diminuição das concentrações de hexoses e pentoses ao longo do tempo, com ênfase para arabinose observada em maior concentração $(870,4$, 925,0, 321,5 e 206,9 mg/L) em R5, R6, R9 e R10, respectivamente.

De fato, as bactérias identificadas neste estudo, semelhantes a Clostridium cellobioparum, C. cellulolyticum e Paenibacillus sp. são celulolíticas (Schleifer, 2010) e podem ter hidrolisado a celulose em vários açúcares. Bactérias semelhantes à $C$. cellulolyticum, Bacteroides sp., Bacillus coagulans e Paenibacullis sp., que são produtores de xilanase (Kotay and Das, 2007; Schleifer, 2010; Song et al., 2010), podem ter convertido a xilose em ácidos orgânicos e gás. B. coagulans também fermenta galactose e manose (Kotay e Das, 2007), enquanto Bacteroides sp., C. cellulolyticum e Enterobacter aerogenes podem 
fermentar arabinose (Grimont e Grimont, 2005; Schleifer, 2010). Desta forma, de acordo com a bioconversão de hexoses e pentoses e com as características fisiológicas das bactérias identificadas neste estudo, pode-se afirmar que, tanto a celulose, como a hemicelulose do BCA foram hidrolisadas pelo consórcio fermentativo e pelas bactérias autóctones do BCA.

\subsubsection{3. Ácidos orgânicos voláteis e álcoois}

Nos reatores do planejamento fatorial, a conversão fermentativa do BCA em hidrogênio foi acompanhada pela formação de ácidos orgânicos voláteis (succínico, lático, fórmico, acético, propiônico, isobutírico, butírico, isovalérico e valérico) e etanol. Observouse 4,46 g/L (R1) até 7,08 g/L (R3) de ácidos orgânicos totais (Figura 5.12). 

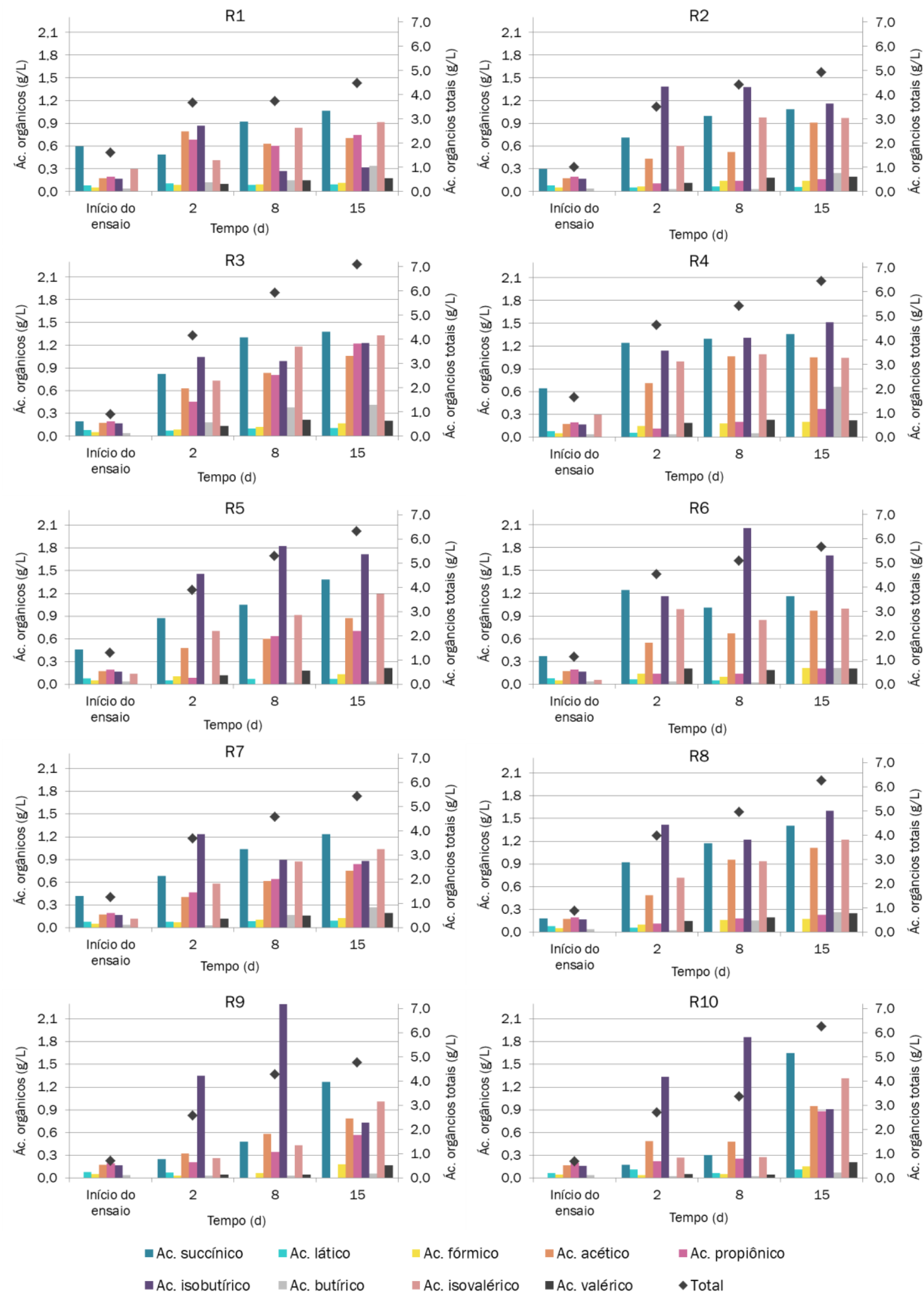

Ac. fórmico
Ac. isovalérico

Ac. acético

Ac. propiônico

- Ac. valérico

- Total

Figura 5.12: Ácidos orgânicos dos reatores em batelada do planejamento fatorial: $R 1$ BCA/L e pH 5,0), R2 (2,0 g BCA/L e pH 7,0), R3 (8,0 g BCA/L e pH 5,0), R4 (8,0 g BCA/L e pH 7,0), R5 $(0,8 \mathrm{~g} \mathrm{BCA} / \mathrm{L}$ e pH 6,0), R6 (9,2 g BCA/L e pH 6,0), R7 (5,0 g BCA/L e pH 4,6), R8 (5,0 g BCA/L e pH 7,4), $\mathrm{R9}$ e R10 (5,0 g BCA/L e pH 6,0). 
Em alguns relatos da literatura científica observou-se divergência em relação à composição dos ácidos orgânicos obtidos da fermentação de BCA ou derivados, sendo dependente, principalmente, do inóculo utilizado. Verificou-se produção de ácidos orgânicos em todos os reatores em batelada. Mesmo nas condições do reator R7 (5,0 g BCA/L e pH 4,6), cuja produção de hidrogênio não foi favorecida $(0,33 \mathrm{mmol} / \mathrm{L})$, verificou-se $5,42 \mathrm{~g} / \mathrm{L}$ de ácidos orgânicos. Resultados similares de produção de ácidos orgânicos com baixa produção de hidrogênio foram reportados por Lin et al. (2008). Tais autores estudaram a conversão da celulose em hidrogênio por inóculo misto de esterco bovino, sob diferentes valores de $\mathrm{pH}(5,5$ a 9,0). Os autores reportaram, ainda, que não foi verificada produção de hidrogênio em pH 5,5, mas produção de ácidos orgânicos (948,6, 44,4 e 189,6 mg/L de ácido acético, propiônico e butírico, respectivamente). Provavelmente, condições com baixos valores de pH (4,6 no presente estudo e 5,0 no estudo de Lin et al., 2008) sejam desfavoráveis para as bactérias produtoras de hidrogênio, no entanto, favorável para as acidogênicas não produtoras de hidrogênio.

Pattra et al. (2008) estudaram hidrolisado de BCA como substrato e cultura pura de Clostridium butyricum como inóculo para produção de hidrogênio. Sob tais condições, os principais ácidos orgânicos observados foram butírico $(76,0 \%)$, acético $(23,2 \%)$ e propiônico (0,8\%). Fangkum e Reungsang (2011) também consideraram o hidrolisado de BCA como substrato para produção de hidrogênio, entretanto, estes autores utilizaram cultura mista obtida de fezes de elefante como inóculo. Os autores relataram que, mesmo variando a concentração inicial de açúcares a partir da hidrólise do BCA, observaram que mais de 90\% dos ácidos totais foram de ácido butírico e ácido acético. Ratti et al. (2015) utilizaram BCA pré-tratado como substrato e cultura mista endógena do BCA como inóculo para produção de hidrogênio e ácido acético, butírico, isobutírico, lático e propiônico. No presente estudo, o inóculo utilizado foi determinante para a composição dos ácidos orgânicos observados (principalmente butírico e succínico), sendo constatação destes ácidos condizente com a fermentação por bactérias semelhantes a Clostridium (Rainey, 2009) e Bacteroides (Song et al., 2010), as quais foram identificadas, tanto no inóculo fermentativo, quanto no BCA pretratado.

Corroborando com a ideia acima apresentada, destaca-se que as bactérias produtoras de hidrogênio e similares a Clostridium, Bacillus e Enterobacter não são favorecidas em condições de pH 4,6 (Grimont e Grimont, 2005; Schleifer, 2010). Por outro lado, gêneros bacterianos acidúricos similares a Lactobacillus e Escherichia, ambos identificados em 
amostras do reator (R9), são favorecidos sob condições de $\mathrm{pH}$ abaixo de 5,0 (Scheutz e Strockbine, 2005; Schleifer, 2010) e podem ter contribuído para a produção de ácidos orgânicos em pH 4,6.

Bactérias similares a Lactobacillus também foram identificadas na comunidade microbiana de reatores EGSB (Cisneros-Pérez et al., 2015). Os autores utilizaram, para a produção de hidrogênio, lodo pré-tratado oriundo de estação de tratamento de esgoto como inóculo e glicose como substrato em pH 5,5. Além de Lactobacillus, representantes similares a Enterobacteriaceae também foram identificados. Semelhante ao presente estudo, provavelmente, tais bactérias foram favorecidas em $\mathrm{pH}$ ácido e corroboraram com a produção de ácidos orgânicos no reator R7. Na Tabela 5.5, pode-se observar a distribuição em porcentagem dos principais ácidos orgânicos formados ao final dos experimentos.

Os principais ácidos orgânicos observados foram butírico (de 14,6 a 33,8\% em R1 e R6, respectivamente), succínico (de 19,5 a 26,4\% em R3 e R9, respectivamente), isovalérico (de 16,2 a 21,2\% em R4 e R9, respectivamente), propiônico (de 3,3 a 17,2\% em R2 e R3, respectivamente) e acético (de 13,8 a 18,5\% em R5 e R2, respectivamente). Por meio dessas variações na distribuição de ácidos orgânicos pode-se inferir que houve alteração das vias fermentativas quando a concentração de substrato e $\mathrm{pH}$ foram alterados. A reorientação do catabolismo celular pela variação da concentração de substrato também foi confirmada por Desvaux et al. (2000) na hidrólise da celulose por C. cellulolyticum. 
Tabela 5.5: Porcentagem dos ácidos orgânico ao final dos experimentos dos reatores em batelada.

\begin{tabular}{ccccccc}
\hline & \multicolumn{5}{c}{ Ácidos orgânicos voláteis (\%) } \\
\cline { 2 - 7 } & Butírico & Succínico & Isovalérico & Propiônico & Acético & Outros** \\
\hline R1 & 14,6 & 23,8 & 20,6 & 16,7 & 15,9 & 8,5 \\
R2 & 28,5 & 22,1 & 19,7 & 3,3 & 18,5 & 8,0 \\
R3 & 23,1 & 19,5 & 18,8 & 17,2 & 14,9 & 6,6 \\
R4 & 29,3 & 21,1 & 16,2 & 10,5 & 16,4 & 6,6 \\
R5 & 27,8 & 21,8 & 18,8 & 11,2 & 13,8 & 6,7 \\
R6 & 33,8 & 20,5 & 17,6 & 3,6 & 17,1 & 7,4 \\
R7 & 21,2 & 22,7 & 19,1 & 15,5 & 13,9 & 7,7 \\
R8 & 29,8 & 22,5 & 19,5 & 3,6 & 17,8 & 6,7 \\
R9 & 16,6 & 26,6 & 21,2 & 11,9 & 16,4 & 7,3 \\
R10 & 15,6 & 26,4 & 21,1 & 14,1 & 15,2 & 7,6 \\
\hline
\end{tabular}

**Outros: Ácidos valérico, fórmico e lático.

R1 (2,0 g BCA/L e pH 5,0), R2 (2,0 g BCA/L e pH 7,0), R3 (8,0 g BCA/L e pH 5,0), R4 (8,0 g BCA/L e pH 7,0), R5 (0,8 g BCA/L e pH 6,0), R6 (9,2 g BCA/L e pH 6,0), R7 (5,0 g BCA/L e pH 4,6), R8 (5,0 g BCA/L e pH 7,4), R9 e R10 (5,0 g BCA/L e pH 6,0).

Nas condições experimentais de R4 $(8,0 \mathrm{~g}$ BCA/L e pH 7,0) foi observada a maior produção de hidrogênio (24,06 $\mathrm{mmol} / \mathrm{L})$, além de ácido butírico e ácido acético (29,3 e $16,4 \%$, respectivamente). Nesta condição (R4), observou-se que o ácido menos produzido foi o ácido propiônico (10,5\%). Em geral, de acordo com as Equações 5.4 e 5.5, tem-se para a fermentação da matéria orgânica, via rota do ácido acético e butírico com produção de hidrogênio (Antonopoulou et al., 2008; Ratti et al., 2014), uma vez que são formados quatro e dois moles de hidrogênio, respectivamente. Todavia, quando a rota do ácido propiônico é favorecida, não há produção de hidrogênio (Equação 5.6).

$$
\begin{aligned}
& \mathrm{C}_{6} \mathrm{H}_{12} \mathrm{O}_{6}+2 \mathrm{H}_{2} \mathrm{O} \rightarrow 2 \mathrm{CH}_{3} \mathrm{COOH}+2 \mathrm{CO}_{2}+4 \mathrm{H}_{2} \\
& \mathrm{C}_{6} \mathrm{H}_{12} \mathrm{O}_{6} \rightarrow 2 \mathrm{CH}_{3} \mathrm{CH}_{2} \mathrm{CH}_{2} \mathrm{COOH}+2 \mathrm{CO}_{2}+2 \mathrm{H}_{2} \\
& \mathrm{C}_{6} \mathrm{H}_{12} \mathrm{O}_{6}+2 \mathrm{H}_{2} \rightarrow 2 \mathrm{CH}_{3} \mathrm{CH}_{2} \mathrm{COOH}+2 \mathrm{H}_{2} \mathrm{O}
\end{aligned}
$$

Equação 5.4

Equação 5.5

Equação 5.6 
No presente estudo o ácido isobutírico, isômero do ácido butírico foi um dos principais ácidos orgânicos observados na fermentação do BCA autoclavado. Wang et al. (1999) confirmaram que ocorre simultânea conversão entre estes dois ácidos pela migração de grupamentos carboxil adjacentes durante a fermentação. Desta forma, considerando as formas isômeras de butírico e isobutírico, como apenas ácido butírico, observou-se valores mais expressivos da concentração deste ácido ao final dos experimentos $(0,7,1,4,1,6,1,9,1,8,1,9$, 1,2, 1,9, 0,8 e 1,0 g/L em R1, R2, R3, R4, R5, R6, 7, R8, R9 e R10, respectivamente).

Com o pressuposto de que as variáveis independentes poderiam também interferir na constituição dos ácidos orgânicos, realizou-se análises de delineamento fatorial por composto central. Apenas as produções finais (\%) de ácidos butírico e succínico foram afetadas em função da concentração de substrato e pH.

De acordo com os diagramas de Pareto (Figura 5.13), os fatores pH e concentração de substrato exerceram efeitos significativos, linear e quadrático, respectivamente, sobre a produção de ácido butírico. A produção de ácido succínico foi afetada significativamente pela concentração de substrato (efeito linear e quadrático) e pelo pH (efeito quadrático). 
(A)

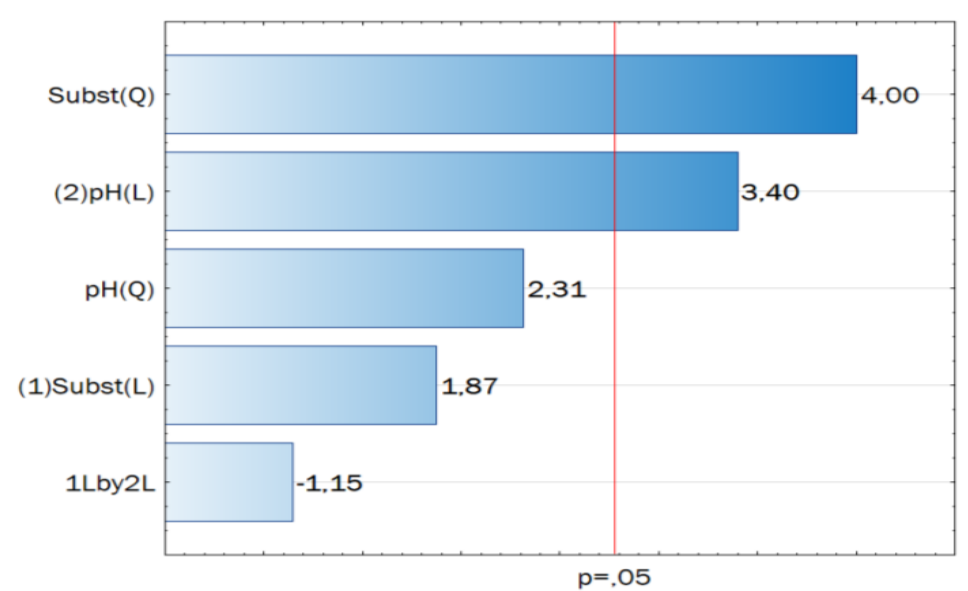

(B)

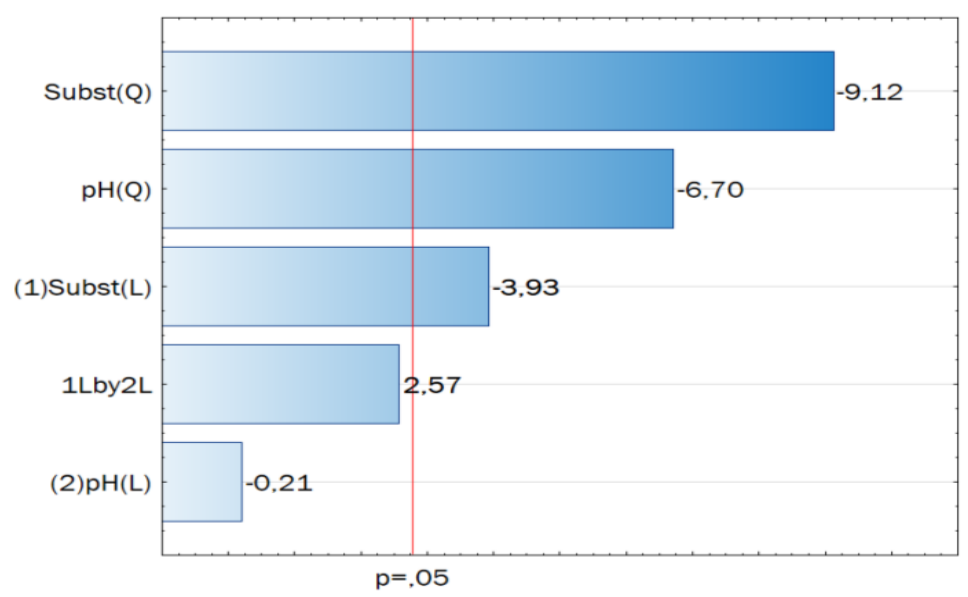

Figura 5.13: Diagramas de Pareto dos efeitos de concentração de substrato e pH sobre a produção de ácido butírico (A) e succínico (B).

L: efeito linear; Q: efeito quadrático e 1Lby2L: efeito da interação entre concentração de substrato e pH

A partir dos efeitos significativos, estão representadas nas Equações 5.7 e 5.8 as equações de regressão dos modelos de produção biológica de ácidos butírico e succínico, respectivamente. Em que, $x_{1}$ representa o valor codificado de concentração de substrato e $x_{2}$ representa o valor codificado de $\mathrm{pH}$. Os ajustes dos modelos foram $89,15 \%$ e $96,64 \%$ da variabilidade de ácidos butírico e succínico, respectivamente.

Ácido Butírico $(\%)=16,1+6,84 \mathrm{x}_{1}^{2}+5,62 \mathrm{x}_{2}$

Equação 5.7

Ácido Succínico $(\%)=26,50-0,89 \mathrm{x}_{1}-2,74 \mathrm{x}_{1}{ }^{2}-2,01 \mathrm{x}_{2}{ }^{2}$

Equação 5.8

Observou-se efeito quadrático positivo em relação a concentração do substrato e ácidos butírico e succiníco. Desse modo, para maior concentração de BCA autoclavado (9,2 g/L) observou-se maior porcentagem de ácido butírico (33,8\%). Efeito linear positivo também foi observado para o ácido succínico $(21,8,22,5,22,7,26,4$ e 26,6\%) a partir do aumento de 0,8 a 5,0 g/L de BCA autoclavado, respectivamente para os reatores R5, R8, R7, R10 e R6. 
No entanto, efeito quadrático negativo foi observado com diminuição da porcentagem desse ácido $(20,5 \%)$ para a maior concentração de BCA autoclavado (9,2 g/L).

Observou-se, também, que as condições de pH 6,0 foram favoráveis para obtenção de maior porcentagem de ácido butírico $(33,8 \%)$. Todavia, efeito linear negativo foi observado para as condições de $\mathrm{pH}$ neutro $(7,0$ e 7,4) com diminuição das porcentagens de ácido butírico para 28,5 (R2), 29,3\% (R4) e 29,8\% (R8), respectivamente. A partir da equação 5.8, também foi observado efeito quadrático negativo em relação ao $\mathrm{pH}$ e porcentagem de ácido succínico, uma vez que a condição de pH $(7,4)$ não foi favorável para a produção desse ácido orgânico $(22,5 \%)$.

A adequação dos modelos foi determinada por análise de variância (ANOVA), conforme Tabela 5.6.

Tabela 5.6: Teste ANOVA para os efeitos da concentração de substrato e pH nas variáveis de produção de ácidos butírico e succínico.

\begin{tabular}{|c|c|c|c|c|c|c|}
\hline Resposta & $\begin{array}{c}\text { Fontes de } \\
\text { variação }\end{array}$ & $\begin{array}{l}\text { Soma de } \\
\text { quadrados }\end{array}$ & $\begin{array}{l}\text { Graus de } \\
\text { Liberdade }\end{array}$ & $\begin{array}{l}\text { Quadrados } \\
\text { médios }\end{array}$ & Fcalculado & Ftabelado \\
\hline \multirow{5}{*}{$\begin{array}{c}\text { Ácido } \\
\text { butírico (\%) }\end{array}$} & Regressão & 467,13 & 2 & 233,56 & \multirow[t]{5}{*}{19,63} & \multirow[t]{5}{*}{19,35} \\
\hline & Resíduo & 83,29 & 3 & 11,90 & & \\
\hline & $\begin{array}{c}\text { Falta de } \\
\text { ajuste }\end{array}$ & 11,15 & 3 & 3,72 & & \\
\hline & Erro puro & 0,50 & 1 & 0,50 & & \\
\hline & Total & 550,41 & 9 & 245,46 & & \\
\hline \multirow{5}{*}{$\begin{array}{c}\text { Ácido } \\
\text { succínico } \\
(\%)\end{array}$} & Regressão & 59,14 & 3 & 20,63 & \multirow[t]{5}{*}{27,21} & \multirow[t]{5}{*}{8,94} \\
\hline & Resíduo & 4,39 & 6 & 0,73 & & \\
\hline & $\begin{array}{l}\text { Falta de } \\
\text { ajuste }\end{array}$ & 1,63 & 3 & 0,54 & & \\
\hline & Erro puro & 0,020 & 1 & 0,020 & & \\
\hline & Total & 63,53 & 9 & 21 & & \\
\hline
\end{tabular}

Pode-se observar que, para os modelos de produção de ácidos butírico e succínico, os valores de Fcalculado (19,63 e 27,21, respectivamente) obtidos foram maiores que os valores de Ftabelado (19,35 e 8,94, respectivamente), refletindo a significância estatística da equação 
obtida. Sendo assim, as superfícies de resposta e curvas de contorno para os ácidos butírico e succínico estão apresentadas nas Figuras 5.14 e 5.15, respectivamente.

A partir da figura 5.14, não foi possível observar uma região específica de relação entre concentração de substrato e pH para melhor resposta da (\%) ácido butírico. Observou-se que as condições de maior porcentagem de ácido butírico foram aquelas com concentração de substrato acima de 9,0 g/L e pH acima de 7,0 e, também, a região com concentração de substrato menor que 2,0 g/L e pH acima de 7,0.
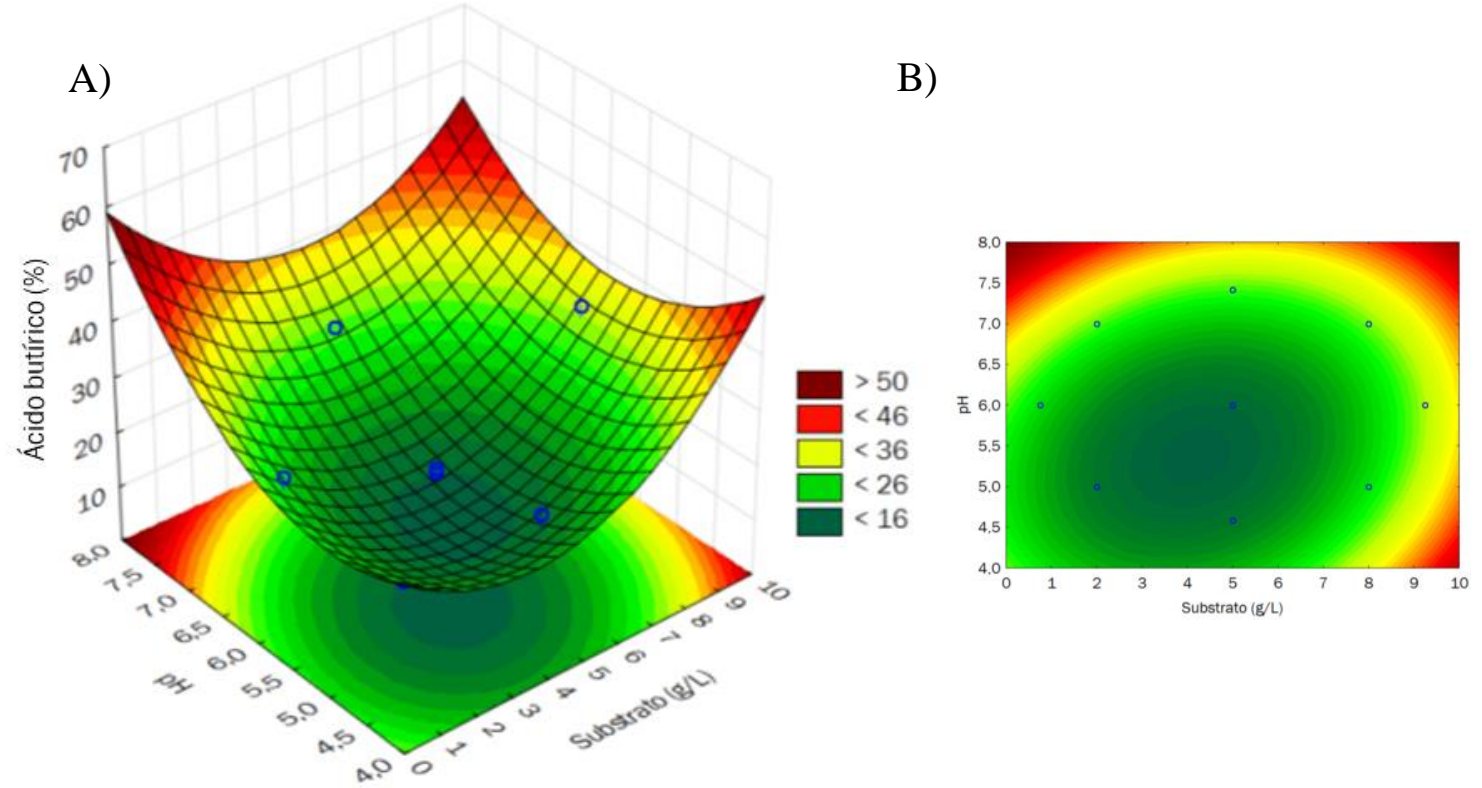

Figura 5.14: Superfície de resposta (A) e Curvas de contorno (B) para porcentagem de ácido butírico.

Em relação ao ácido succínico observou-se que o ponto ótimo pode ser verificado no pico formado na superfície do gráfico, com concentração de substrato próxima a 4,5 g/L e pH 6,0 . 
A)

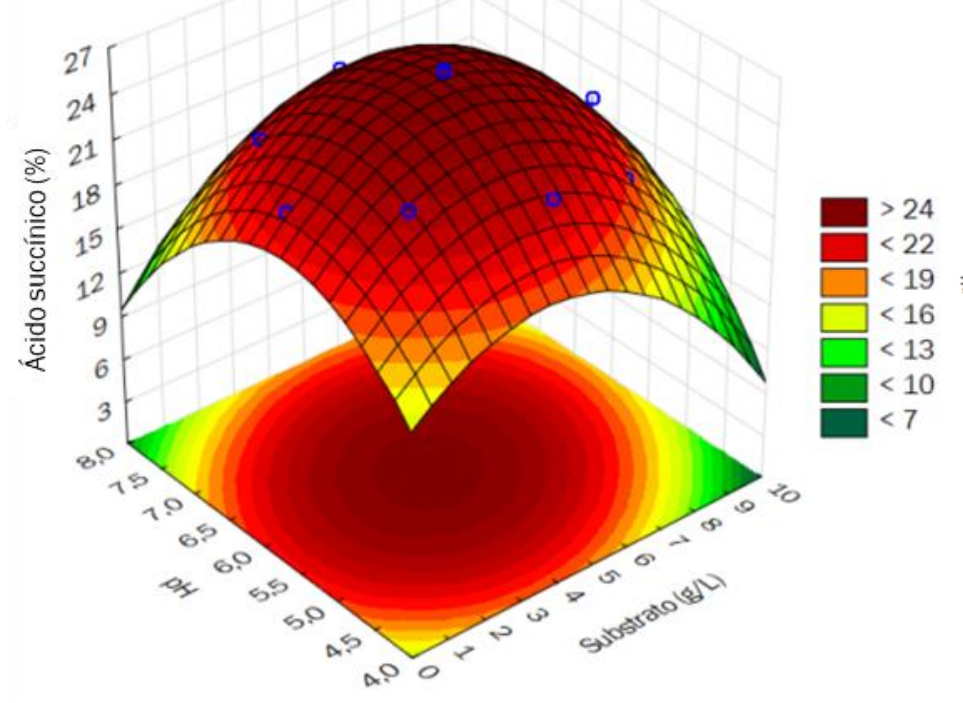

B)

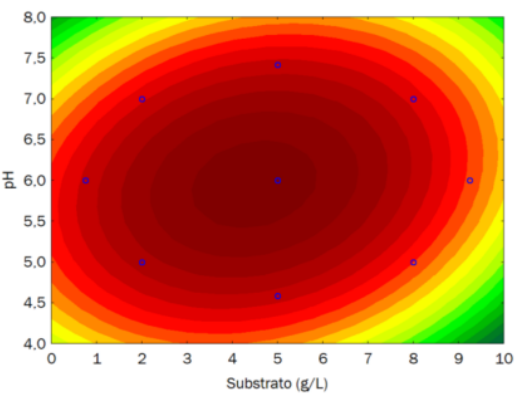
succínico.

Figura 5.15: Superfície de resposta (A) e Curvas de contorno (B) para porcentagem de ácido

A otimização da produção dos ácidos butírico e isobutírico foi um objetivo importante deste estudo, uma vez que pode ser considerada abordagem promissora de obtenção de compostos químicos denominados de "blocos de construção" possíveis de serem utilizados como precursor de muitos compostos, tais como, anidrido maleico (obtido do petróleo) e fragrâncias, respectivamente (Sauer et al., 2008).

Além dos ácidos orgânicos observou-se também etanol em todos os reatores (Figura 5.16), principalmente na fase final e de maior produção de hidrogênio, a partir de 8 até 15 dias de operação. O etanol é um dos produtos da fermentação da celulose por espécies de Clostridium (Rainey, 2009). Observou-se de 34,9 mg/L até 120,1 mg/L de etanol em R9 (5,0 g BCA/L e pH 6,0) e R8 (5,0 g BCA/L e pH 7,4), respectivamente. De acordo com o teste ANOVA, com nível de significância de 5\%, a produção de etanol não foi influenciada pelos fatores concentração de substrato e $\mathrm{pH}$. 


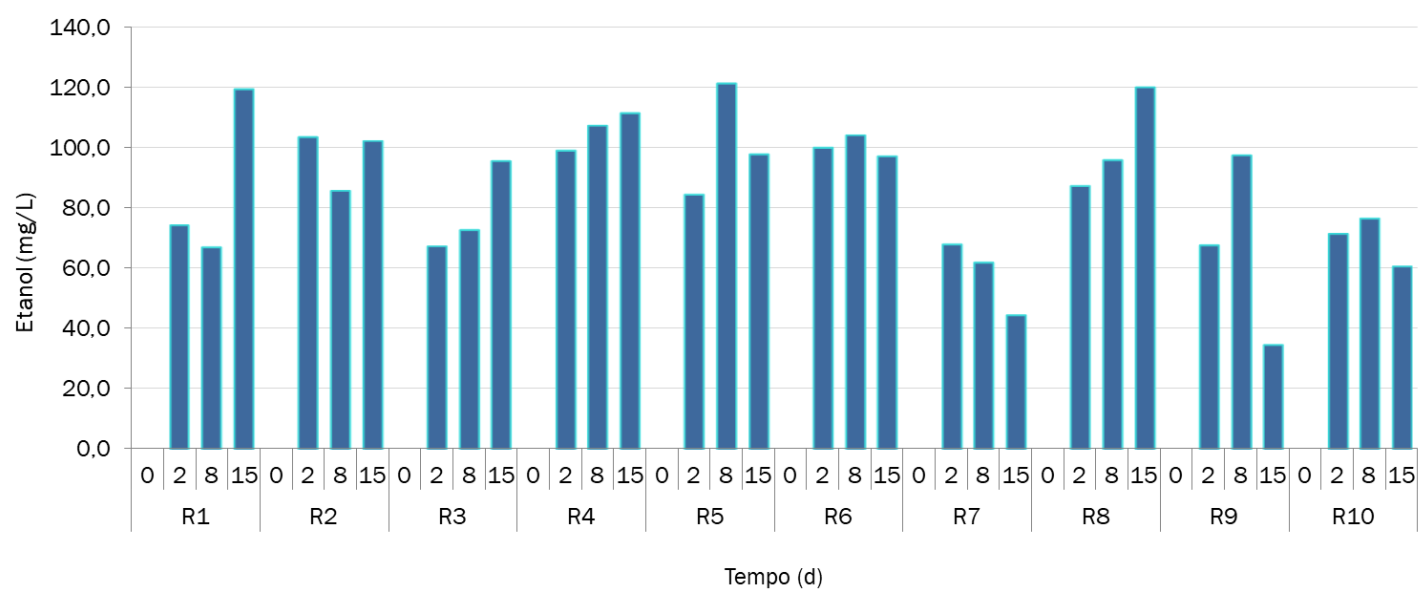

Figura 5.16: Etanol nos reatores do planejamento fatorial: R1 (2,0 g BCA/L e pH 5,0), R2 (2,0 g BCA/L e pH 7,0), R3 (8,0 g BCA/L e pH 5,0), R4 (8,0 g BCA/L e pH 7,0), R5 (0,8 g BCA/L e pH 6,0), R6 $(9,2$ g BCA/L e pH 6,0), R7 (5,0 g BCA/L e pH 4,6), R8 (5,0 g BCA/L e pH 7,4), R9 e R10 (5,0 g BCA/L e pH 6,0).

A produção de etanol a partir da fermentação do BCA também foi relatada por outros autores. Soares et al. (2017) obtiveram 38,4 mg/L de etanol com BCA pré-tratado hidrotermicamente como substrato $(2,0 \mathrm{~g} / \mathrm{L})$ e lodo de reator UASB como inóculo. Ratti et al. (2015) obtiveram 23,3 e 112,1 mg/L de etanol com BCA $(0,5$ e 2,0 g BCA/L, respectivamente) in natura e bactérias endógenas do BCA. Assim como nos trabalhos citados, a produção de etanol no presente estudo não foi muito expressiva (de 34,9 a 120,1 mg etanol/L) e pode ser decorrente da fermentação mista que, conforme já relatado, além de etanol, há formação de vários outros subprodutos. Esta conversão direta de substratos celulósicos em etanol costuma ser lenta e ter baixo rendimento, o que pode estar relacionado à baixa resistência dos microrganismos ao etanol (Szczodrak e Fiedurek, 1996).

\subsubsection{Matéria Seca e Matéria Orgânica}

A matéria seca (MS) foi calculada a fim quantificar a massa total de BCA removida ao longo dos experimentos (Tabela 5.7). Os valores de MS das amostras iniciais dos reatores foram dependentes da concentração inicial de BCA, ou seja, para maior concentração inicial de BCA foi observado maior o valor de MS. Em relação aos valores de matéria orgânica (MO) pode-se observar para as amostras iniciais variação de 43 a 57,9\% (R2 e R4, respectivamente). Todavia, para as amostras finais observou-se de 38,8 a 52,5\% (R2 e R6, respectivamente). Esta diminuição de $\mathrm{MO}$ e, principalmente de MS foi decorrente da 
degradação do substrato sólido nos reatores de produção de hidrogênio e indicativo da atividade de bactérias celulolíticas.

Tabela 5.7: Matéria seca (MS) e orgânica (MO) nas amostras iniciais e finais dos reatores do planejamento fatorial.

\begin{tabular}{|c|c|c|c|c|c|c|c|c|}
\hline & & & & & & & & \\
\hline & $\mathrm{BCA}$ & $\mathrm{pH}$ & MS & MO & MS & $\mathrm{MO}$ & removida & removida \\
\hline & $(\mathrm{g} / \mathrm{L})$ & & $(\mathrm{g} / \mathrm{L})$ & $(\%)$ & $(\mathrm{g} / \mathrm{L})$ & $(\%)$ & $(\mathrm{g} / \mathrm{L})$ & $(\%)$ \\
\hline $\mathrm{R} 1$ & 2,0 & 5,0 & 16,1 & 44,5 & 15,0 & 39,9 & 1,1 & 6,8 \\
\hline $\mathrm{R} 2$ & 2,0 & 7,0 & 15,9 & 43,0 & 14,2 & 38,8 & 1,7 & 10,7 \\
\hline $\mathrm{R} 3$ & 8,0 & 5,0 & 21,0 & 56,2 & 18,7 & 49,8 & 2,2 & 10,6 \\
\hline $\mathrm{R} 4$ & 8,0 & 7,0 & 22,3 & 57,9 & 19,7 & 51,8 & 2,6 & 11,7 \\
\hline R5 & 0,8 & 6,0 & 15,0 & 39,7 & 13,3 & 38,9 & 1,7 & 11,3 \\
\hline R6 & 9,2 & 6,0 & 21,9 & 57,7 & 19,4 & 52,5 & 2,5 & 11,5 \\
\hline $\mathrm{R} 7$ & 5,0 & 4,6 & 18,3 & 50,5 & 16,9 & 45,5 & 1,4 & 7,6 \\
\hline $\mathrm{R} 8$ & 5,0 & 7,4 & 18,9 & 48,7 & 17,0 & 47,0 & 1,9 & 10,2 \\
\hline R9 & 5,0 & 6,0 & 17,8 & 48,6 & 13,9 & 50,7 & 4,0 & 21,8 \\
\hline R10 & 5,0 & 6,0 & 19,7 & 50,9 & 15,7 & 47,4 & 3,9 & 20,0 \\
\hline
\end{tabular}

Observou-se variação de $1,1 \mathrm{~g} / \mathrm{L}(6,8 \%)$ a $4,0 \mathrm{~g} / \mathrm{L}(21,8$ e $20,0 \%)$ da massa seca removida durante 15 dias de operação dos reatores, respectivamente, para R1 e R9 e R10. De acordo com a Tabela 5.7, pode-se observar que os menores valores de remoção de BCA são referentes aos R1 e R7 (6,8 e 7,6\%), que são aqueles reatores que foram operados em pH ácido (5,0 e 4,6, respectivamente). O pH pode afetar diretamente a hidrólise do BCA, uma vez que, as bactérias anaeróbias celulolíticas são particularmente sensíveis à variações de pH (Desvaux, 2005). De acordo com esta observação, pode-se inferir que baixos valores de $\mathrm{pH}$ interferiram na atividade celulolítica e, consequentemente, na degradação do BCA.

A concentração de substrato é outro fator que afeta o rendimento de hidrólise da biomassa lignocelulósica. Manter altas concentrações de sólidos permite a produção de solução concentrada de açúcar, que é benéfica para a subsequente fermentação. Por outo lado, 
a elevada concentração de açúcares também pode causar a inibição do substrato, o que reduz substancialmente a taxa de hidrólise (Binod et al., 2011). No presente estudo, as maiores taxas de remoção de matéria seca $(21,8$ e 20,0\%) foram obtidas para concentração inicial de 5,0 g de BCA/L, o que pode indicar que esta concentração de substrato não foi inibitória para as bactérias celulolíticas.

Para melhor análise dos dados, os valores das variáveis concentração de substrato, $\mathrm{pH}$ e da resposta remoção de MS foram ajustados ao delineamento composto central.

Pode-se observar, de acordo com o gráfico de Pareto com 95\% de confiança os efeitos da concentração de substrato e pH na remoção da matéria seca (Figura 5.17). Por meio dos coeficientes obtidos no gráfico de Pareto pode-se inferir que a variável $\mathrm{pH}$ foi a que mais exerceu efeito na resposta remoção de MS.

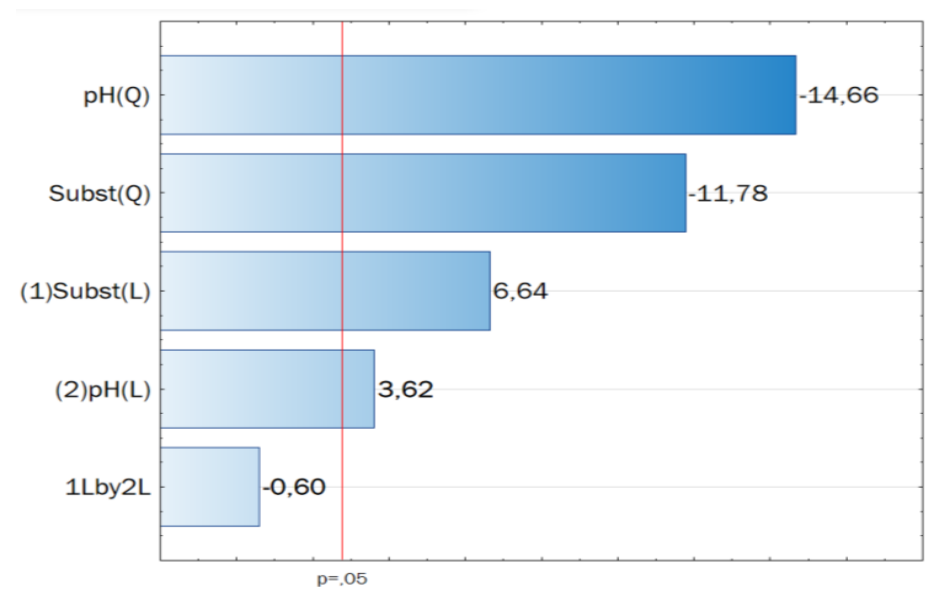

Figura 5.17: Diagrama de Pareto com o efeito dos fatores concentração de substrato e pH sobre na remoção de matéria seca.

L: efeito linear; Q: efeito quadrático e 1Lby2L: efeito da interação entre concentração de substrato e pH

A equação de regressão do modelo de remoção de matéria seca dependente da concentração de substrato e pH está representada na Equação 5.9. Em que $M S$ é o valor previsto de remoção de matéria seca $(\mathrm{g} / \mathrm{L}), x_{1}$ o valor codificado de concentração de substrato $(\mathrm{g} / \mathrm{L})$ e $x_{2}$ representa o valor codificado de $\mathrm{pH}\left(\mathrm{R}^{2}=0,99\right)$.

$$
\mathrm{MS}=3,95+0,39 \mathrm{x}_{1}-0,92 \mathrm{x}_{1}^{2}+0,21 \mathrm{x}_{2}-1,14 \mathrm{x}_{2}^{2}
$$

A partir do teste ANOVA, observou-se valor de Fcalculado maior em relação ao valor de Ftabelado (117,79 e 5,19, respectivamente), logo, obtive-se valor de regressão $(2,86)$ e resíduo $(0,024)$ estatisticamente diferentes (Tabela 5.8). 
Tabela 5.8: Teste ANOVA para os efeitos da concentração de substrato e pH na remoção de matéria seca (MS).

\begin{tabular}{ccccccc}
\hline \multirow{2}{*}{ Resposta } & $\begin{array}{c}\text { Fontes de } \\
\text { variação }\end{array}$ & $\begin{array}{c}\text { Soma de } \\
\text { quadrados }\end{array}$ & $\begin{array}{c}\text { Graus de } \\
\text { Liberdade }\end{array}$ & $\begin{array}{c}\text { Quadrados } \\
\text { médios }\end{array}$ & Fcalc & Ftab \\
\hline Regressão & 11,43 & 4 & 2,86 & 117,79 & 5,19 \\
$\begin{array}{c}\text { Remoção de } \\
\text { MS }\end{array}$ & Resíduo* & 0,12 & 5 & 0,024 & & \\
$(\mathrm{~g} / \mathrm{L})$ & Erro puro & 0,11 & 4 & 0,028 & & \\
& Total & 11,55 & 9 & 3,00 & \\
\hline
\end{tabular}

*O efeito não significativo foi considerado como informação não modelada (resíduo).

A partir do gráfico de superfície de resposta e curva de contorno, podem-se analisar os efeitos dos fatores estudados na remoção de matéria seca (Figura 5.18 A e B).

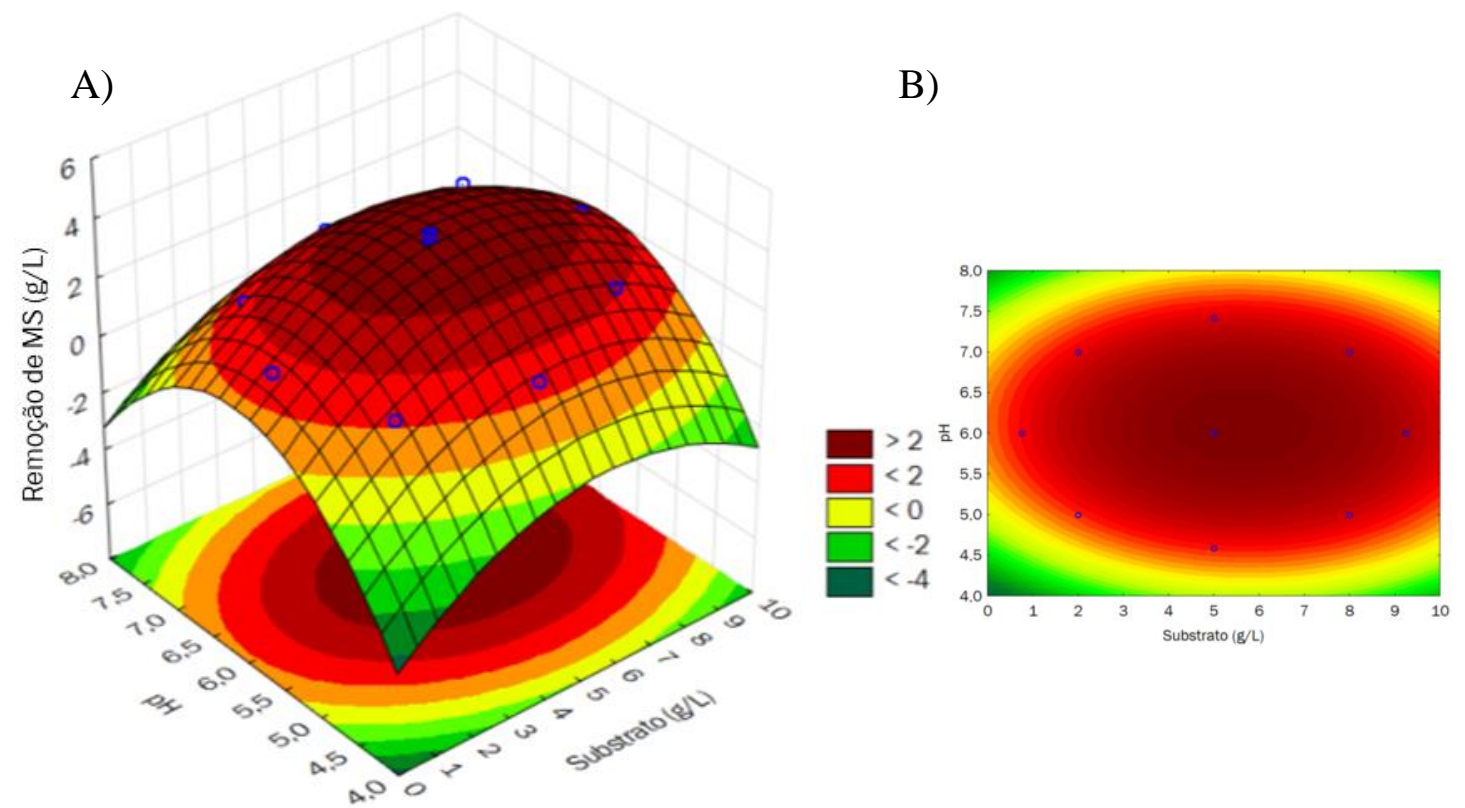
(MS).

Figura 5.18: Superfície de resposta (A) e curvas de contorno (B) para remoção de matéria seca

Pode-se averiguar, tanto na superfície de resposta, quanto nas curvas de contorno (Figura 5.18 A e B) que a região ótima para resposta remoção de MS encontra-se com concentração de substrato próxima a 5,5 e pH 6,0. De fato, os pontos críticos calculados que levam ao máximo de remoção de MS (4,0 g/L), corresponderam à concentração de substrato de 5,6 g/L e pH 6,1. Valores estes bem próximos aos pontos centrais do planejamento fatorial 
(R9 e R10 com 5,0 g BCA/L e pH 6,0) com remoção de matéria seca de 4,0 g/L, validando assim o modelo de remoção de MS em função da concentração de substrato e pH.

\subsubsection{Validação do modelo de produção de hidrogênio}

As condições ótimas preditas foram utilizadas nos reatores de otimização $(7,0 \mathrm{~g} / \mathrm{L}$ de BCA e pH 7,2) a fim de validar o modelo de produção de hidrogênio em função da concentração de substrato e $\mathrm{pH}$..

Sob as condições ótimas de concentração de substrato (7,0 g BCA/L) e pH (7,2), o valor de produção de hidrogênio foi de 19,84 mmol/L (Rotm) (Figura 5.19), indicando boa correlação com o valor predito $(23,10 \mathrm{mmol} / \mathrm{L})$. Desta forma, a partir do ensaio de validação, obteve-se grau de precisão do modelo de 85,9\% para produção de hidrogênio a partir de BCA.

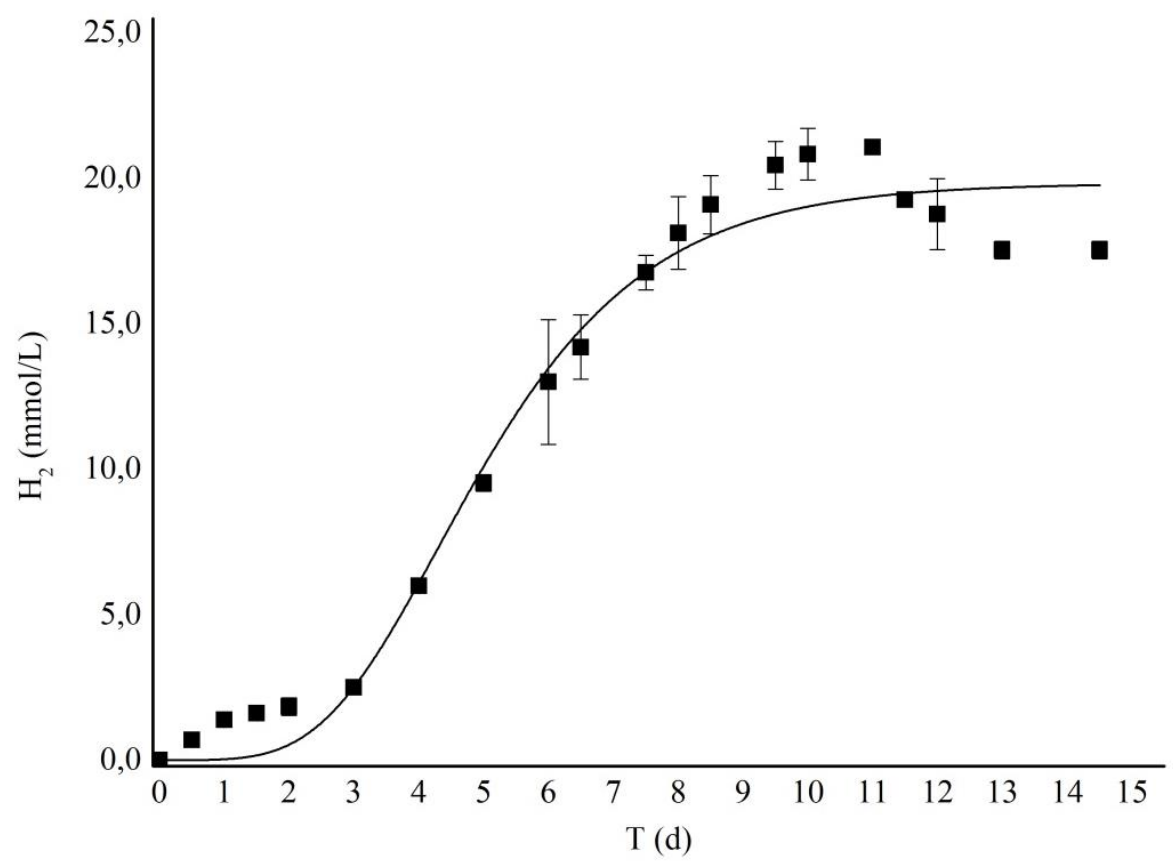

Figura 5.19: Produção de hidrogênio a partir do BCA autoclavado em reator em batelada com as condições otimizadas (Rotm: 7,0 g BCA/L e pH 7,2).

Em Rotm, verificou-se arabinose, galactose, glicose, manose e xilose. A maior concentração de açúcar detectada foi $1.655,71 \mathrm{mg} / \mathrm{L}$ de arabinose no oitavo dia de fermentação (Figura 5.20). 


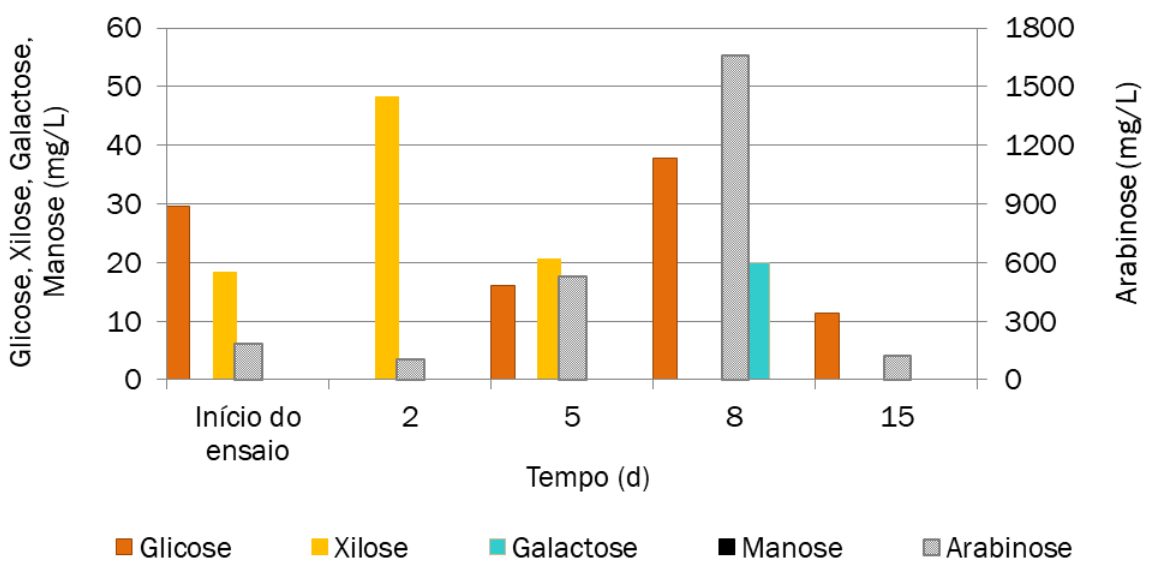

Figura 5.20: Perfil de açúcares solúveis nos reator com as condições otimizadas (Rotm: 7,0 g BCA/L e pH 7,2).

Observou-se que o perfil de ácidos orgânicos voláteis sob as condições do Rotm (7,0 $\mathrm{g} / \mathrm{L}$ de substrato e $\mathrm{pH} 7,2$ ), foi semelhante dos demais reatores do planejamento fatorial. Os principais ácidos orgânicos observados foram: ácidos acético (1,57 g/L), succínico (1,21 g/L), isobutírico $(1,20 \mathrm{~g} / \mathrm{L})$, isovalérico $(0,61 \mathrm{~g} / \mathrm{L})$ e propiônico $(0,85 \mathrm{~g} / \mathrm{L})$, totalizando $92,1 \%$ dos ácidos identificados (Figura 5.21).

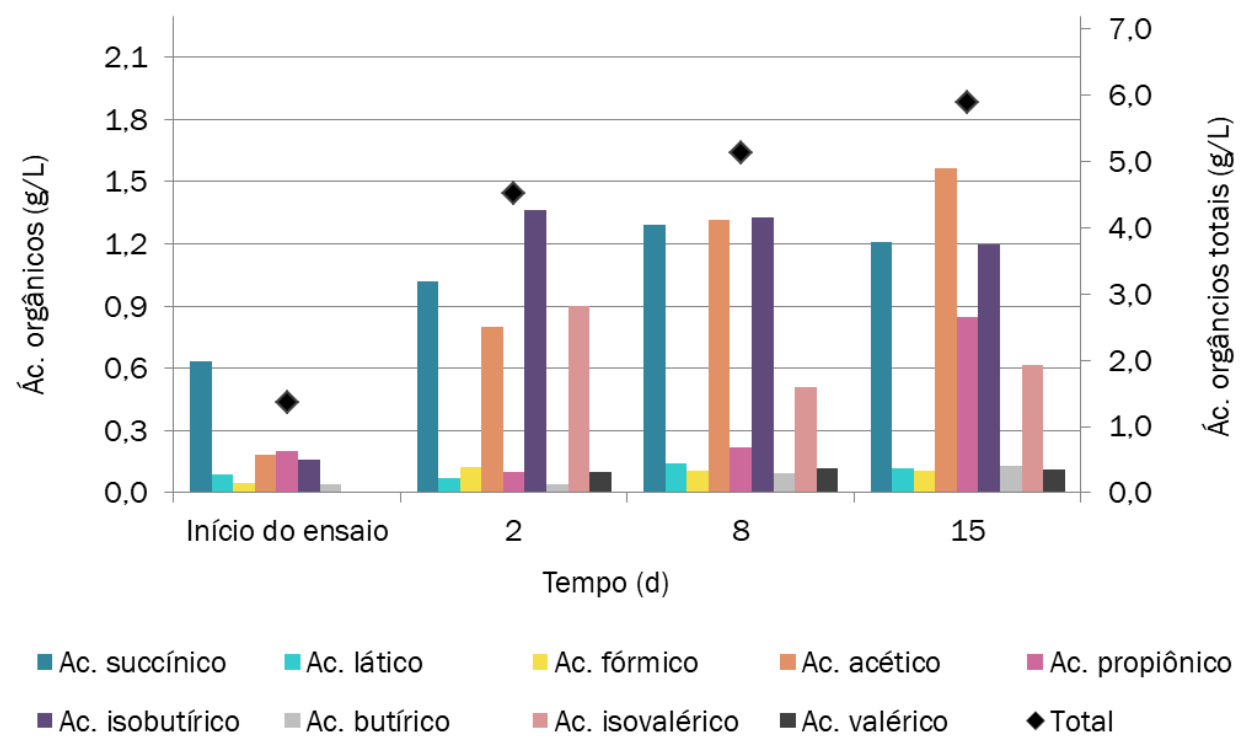

Figura 5.21: Ácidos orgânicos do reator otimizado de produção de hidrogênio (Rotm: 7,0 g $\mathrm{BCA} / \mathrm{L}$ e pH 7,2).

As condições do Rotm $(7,0$ g BCA/L e pH 7,2) foram favoráveis à produção de ácido acético, uma vez que este foi o principal ácido formado $(1,57 \mathrm{~g} / \mathrm{L})$. 
A predominância de ácido acético em processo fermentativo a partir de substratos celulósicos e culturas mistas têm sido amplamente reportada e, frequentemente relacionadas a Clostridium. Chu et al. (2011) utilizaram palha de trigo como substrato para produção de hidrogênio e compararam o uso de dois inóculos, lodos ativados e esterco digerido. Os autores verificaram que a produção de ácido acético foi proeminente (83,1 e 90,1\% dos ácidos formados, respectivamente) com ambos os inóculos. Ratti et al. (2013) utilizaram celulose como substrato $(2,5,5,0$ e $10,0 \mathrm{~g} / \mathrm{L})$ para produção de hidrogênio e lixiviado de aterro sanitário como inóculo. Sob tais condições, os autores verificaram que os principais ácidos formados foram butírico, isobutírico e acético, totalizando mais de $80 \%$ em todas as condições testadas. Os autores relacionaram a produção de ácido acético com Clostridium identificado a partir da clonagem e sequenciamento do gene RNAr 16S.

O ácido acético é um dos principais produtos da fermentação de substratos celulósicos por bactérias celulolíticas, como C. cellulolyticum (Desvaux, 2005), e pode indicar atividades destas bactérias na hidrólise e fermentação do BCA autoclavado em Rotm.

Além de ácido acético (26,6\%), foram também observados ácidos butírico (22,5\%), succínico $(20,5 \%)$, propiônico $(14,4 \%)$ e isovalérico $(10,32 \%)$. A variedade de ácidos orgânicos obtidos no presente estudo foi, provavelmente, relacionada à alta abundância de bactérias semelhantes a Bacteroides (37\%). Bacteroides podem converter muitos coprodutos da hidrólise da celulose em ácidos succinico, acético, isobutírico e isovalérico (Deublein e Steinhauser, 2010; Song et al., 2010).

Bacteroides sp. foram identificados em culturas com celulose (Ho et al., 2012; Gupta et al., 2014a). Conforme os resultados do presente estudo, tais representantes desse gênero, em sintrofia com bactérias celulolíticas e outras fermentativas converteram carboidratos complexos, como BCA, em ácidos orgânicos e hidrogênio, ambos de interesse biotecnológico.

O resultado de remoção de matéria seca em Rotm que foi de 20,7\%, semelhante aos melhores resultados dos reatores do planejamento fatorial (21,8 e 20,0\% em R9 e R10, respectivamente).

Em Rotm foi realizada análise de contagem das bactérias anaeróbias viáveis do reator, a fim de verificar crescimento e/ou inibiçao das mesmas em condição otimizada de concentração de substrato e pH (Figura 5.22). 


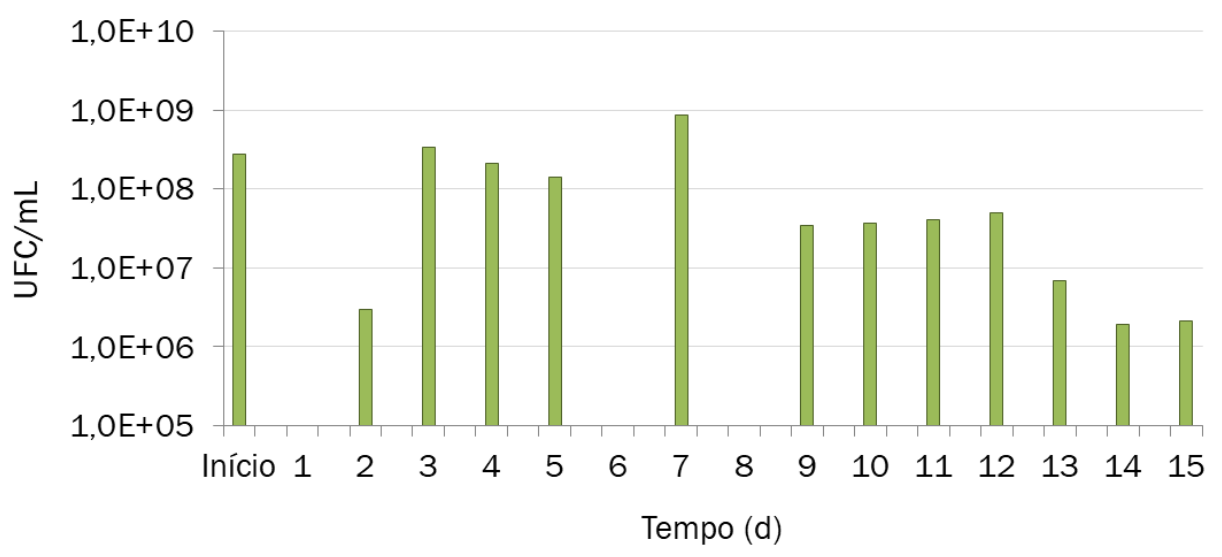

Figura 5.22: Contagem das bactérias anaeróbias viáveis (UFC/mL) ao longo do tempo (d) em $\operatorname{Rotm}(7,0 \mathrm{~g} \mathrm{BCA} / \mathrm{L}$ e pH 7,2).

Pode-se observar que houve declínio da concentração de bactérias viáveis de $2,8 \times 10^{8}$ (início de operação) para 3,0 x $10^{6} \mathrm{UFC} / \mathrm{mL}$ (em $48 \mathrm{~h}$ de operação). Este período foi, provavelmente, referente à adaptação das bactérias às novas condições, principalmente ao BCA autoclavado utilizado como substrato.

As maiores concentrações de bactérias viáveis ocorreram no período de produção exponencial de hidrogênio (48h a 192h). Durate este período verificou-se que a produção de hidrogênio aumentou exponencialmente de 1,85 para $15,31 \mathrm{mmol} / \mathrm{L}$, houve também maior liberação de açúcares no meio, como glicose $(27,74 \mathrm{mg} / \mathrm{L})$, galactose $(19,88 \mathrm{mg} / \mathrm{L})$ e arabinose $(1.655,71 \mathrm{mg} / \mathrm{L})$ em Rotm.

A análise dos resultados de ácidos orgânicos também corrobora com a maior atividade bacteriana durante o período de $48 \mathrm{~h}$ a $192 \mathrm{~h}$. Neste período, a concentração de ácidos orgânicos aumentou de 4,52 para 5,13 g/L. Destaca-se que o aumento da concentração de ácido acético durante a fermentação de substratos celulolíticos é decorrente do crescimento exponencial celular (Guedon et al., 1999a), especificamente, observou-se em Rotm aumento de 0,80 para 1,32 g/L de ácido acético no período de 48h a 192h de operação, provavelmente, decorrente do crescimento de bactérias celulolíticas e fermentativas em Rotm.

Após o oitavo dia, verificou-se diminuição do crescimento celular, visto que não houve mais aumento no número de células viáveis no reator, provavelmente, devido as condições de operação do sistema em batelada e devido ao próprio padrão de crescimento das populações do consórcio de bactérias celulolíticas e fermentativas.

Desta forma, pode-se concluir que na condição otimizada de concentração de substrato $(7,0$ g BCA/L) e $\mathrm{pH}(7,2)$ observou-se crescimento de bactérias celulolíticas e fermentativas, 
visto que houve remoção de matéria seca e foram produzidos açúcares, ácidos orgânicos e hidrogênio.

\subsubsection{Caracterização microbiana}

\subsubsection{Eletroforese em Gel com Gradiente Desnaturante}

A fim de comparar a estrutura das comunidades dos reatores do planejamento fatorial, procedeu-se a análise de Eletroforese em Gel de Gradiente Desnaturante (DGGE). Pretendeuse avaliar a influência da variação da concentração de BCA autoclavado e pH na comunidade bacteriana.

Este estudo da comunidade bacteriana foi estimulado principalmente pela hipótese de que as diferentes concentrações de substrato e da presença de bactérias autóctones do BCA, além do $\mathrm{pH}$, poderiam interferir na estrutura da comunidade dos reatores de produção de hidrogênio. Relatos na literatura corroboram com esta ideia. Gomez-Romero et al. (2014) investigaram a codigestão de soro de queijo bruto com resíduos vegetais de frutas em diferentes proporções (100:0, 75:25, 50:50, 25:75, e 0:100). Após análise da comunidade bacteriana por pirosequenciamento, os autores relataram que a composição do substrato foi um fator determinante na estrutura da comunidade bacteriana. Ratti et al. (2015a) analisaram a produção de hidrogênio a partir de BCA e lodo de reator UASB como inóculo e observaram alteração das populações em função do aumento da concentração de substrato.

De acordo com o padrão de bandas de DGGE dos reatores do planejamento fatorial (Figura 5.23) foi possível observar alteração nas populações de bactérias de acordo com as variações de concentração de substrato e $\mathrm{pH}$, uma vez que são os únicos fatores que diferem dentre os parâmetros dos reatores em batelada. A partir do dendograma (Figura 5.23), verificou-se clara separação das populações em dois grupos: G1 (R2, R6, R4, R8, R3 R9 e 10) agrupado com $61 \%$ de similaridade e G2 (R5, R7 e R1) agrupado com 64\% de similaridade. 


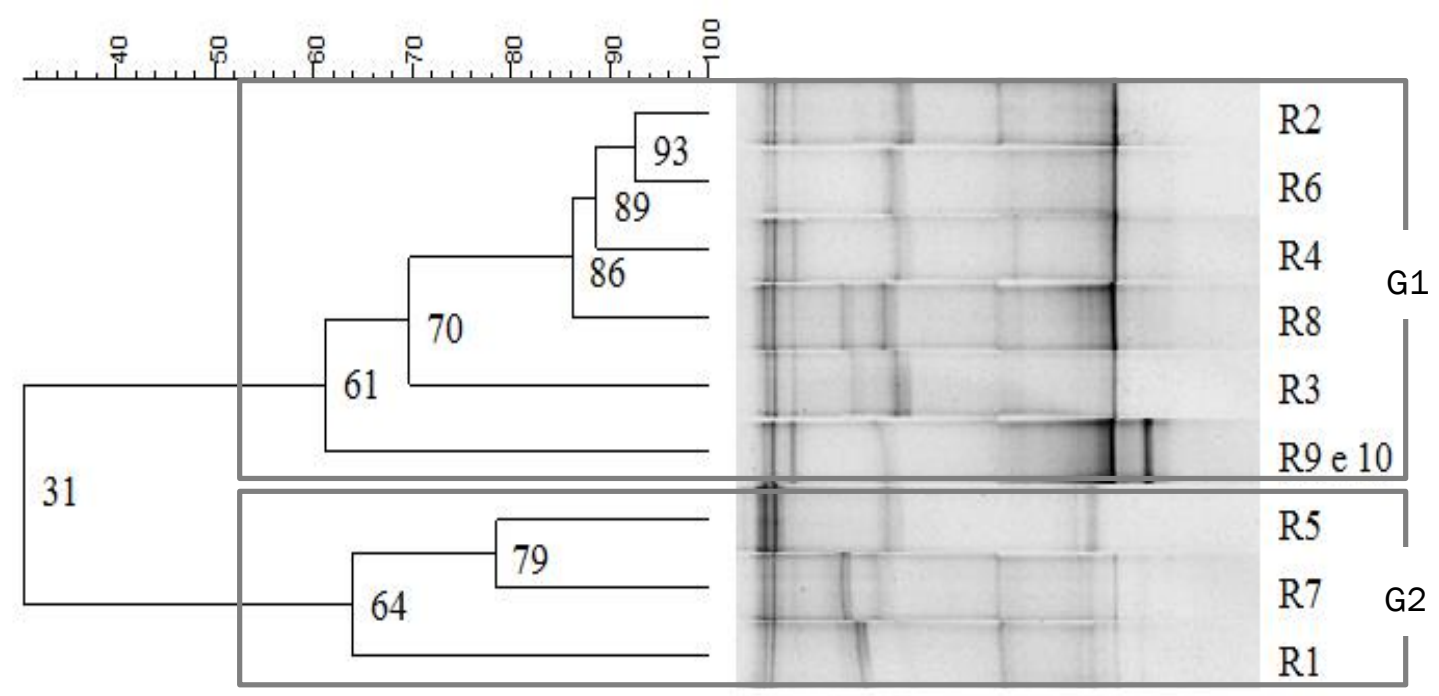

Figura 5.23: Dendograma baseado no coeficiente se similaridade de Pearson a partir do padrão de bandas do DGGE do gene RNAr 16S para o Domínio Bacteria. Reatores do planejamento: R1 $(2,0 \mathrm{~g}$ BCA/L e pH 5,0), R2 (2,0 g BCA/L e pH 7,0), R3 (8,0 g BCA/L e pH 5,0), R4 (8,0 g BCA/L e pH 7,0), R5 $(0,8$ g BCA/L e pH 6,0), R6 (9,2 g BCA/L e pH 6,0), R7 (5,0 g BCA/L e pH 4,6), R8 (5,0 g BCA/L e pH 7,4), R9 e R10 (5,0 g BCA/L e pH 6,0), separadas em dois grupos G1 e G2.

Verificou-se para as populações agrupadas em G1 valores mais elevados de produção de hidrogênio $\left(12,79,13,64,24,06,20,13,7,31\right.$ e 18,0 $\mathrm{mmol} \mathrm{H}_{2} / \mathrm{L}$, respectivamente, para $\mathrm{R} 2$, R6, R4, R8, R3 e R9 e R10). Observou-se, ainda, 86\% de similaridade entre R2, R6, R4 e R8 que foram aqueles reatores que, além de possuírem os mais elevados valores de produção de hidrogênio, tinham em comum pH acima de 6,0 e concentração de BCA acima de 2,0 g/L. Estas características em conjunto favoreceram a produção de hidrogênio. Desta forma, podese inferir que as populações dos reatores com maior produção de hidrogênio foram mais semelhantes entre si.

Em contrapartida, menores valores de produção de hidrogênio $(0,33,1,64$ e 6,79 mmol/L) foram obtidos, respectivamente, em R7, R1 e R5 (G2) com 64\% de similaridade entre as populações e com apenas $31 \%$ de similaridade em relação a G1. Portanto, pode-se inferir que as populações bacterianas dos reatores em condição de $\mathrm{pH}$ ácido $(4,6$ a 5,0) e baixa concentração de BCA (0,8 a 5,0 g/L) foram mais semelhantes entre si.

Outra análise de DGGE foi realizada para comparar o efeito das bactérias autóctones do BCA e das bactérias do consórcio fermentativo (inóculo) na composição final da comunidade bacteriana. Para tanto, a análise foi realizada com amostras do reator com as condições otimizadas (Rotm), amostras do BCA e inóculo (Figura 5.24). 


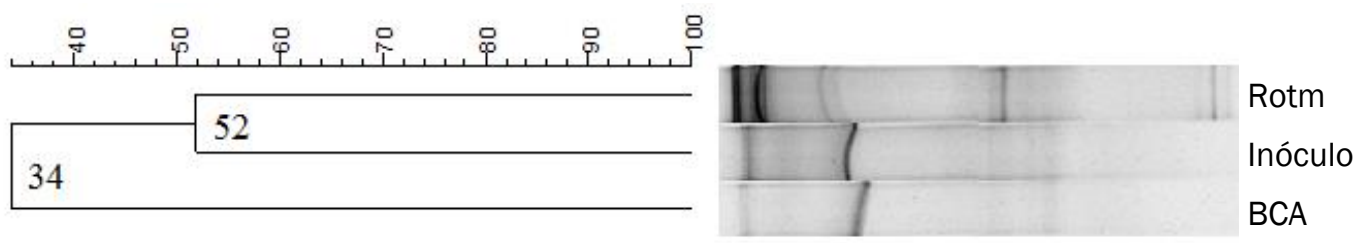

Figura 5.24: Dendograma baseado no coeficiente de similaridade de Pearson a partir do padrão de bandas do DGGE do gene RNAr 16S para o Domínio Bacteria. (Rotm: 7,0 g BCA/L e pH 7,2).

Desta forma, de acordo com o dendograma, pode-se observar similaridade de $52 \%$ entre as populações do Rotm com o inóculo fermentativo, bem como de $34 \%$ entre as populações do reator e das populações autóctones do BCA.

Wang et al. (2013) avaliaram a produção e hidrogênio a partir de vinhaça de mandioca juntamente com diferentes resíduos orgânicos como cossubstratos (resíduo de mandioca, esterco suíno, esterco bovino e lodo ativado). De acordo com a análise de DGGE realizada por estes autores, a adição de pequenas quantidades de cossubstrato alterou as populações bacterianas de todo o sistema, com alteração delas em função do cossubstrato utilizado. No presente estudo, pode-se inferir que o BCA autoclavado, juntamente com as condições diferenciadas de concentração de substrato e $\mathrm{pH}$ impostas aos reatores, contribuiu e alterou as populações bacterianas dos reatores fermentativos.

\subsubsection{Caracterização filogenética}

Nesse trabalho, a fim de confirmar os questionamentos abordados sobre a contribuição de populações de bactérias oriundas do BCA na comunidade final dos reatores, a caracterização filogenética bacteriana foi realizada pelo sequenciamento via plataforma Illumina-Miseq em quatro amostras: (1) inóculo, (2) BCA, (3) reator de ponto central (R9: 5,0 g BCA/L e pH 6,0) e (4) reator com as condições otimizadas do planejamento fatorial (Rotm: 7,0 g BCA/L e pH 7,2). Para as quatro amostras, obteve-se total de 405.245 sequências de genes RNAr 16S, sendo 88.278 sequências para a amostra do inóculo, 96.791 para BCA, 83.047 para R9 e 137.129 para Rotm.

As OTUs (Unidades Taxonômicas Operacionais) foram agrupadas considerando similaridade maior ou igual a 97\% e, após a remoção de singletons, obteve-se 36 OTUs para amostra do inóculo, 64 para BCA, 51 para R9 e 50 OTUs para Rotm (Tabela 5.9). 
Tabela 5.9: Resultados do sequenciamento de bactérias das amostras inóculo, BCA, R9 e Rotm.

\begin{tabular}{ccccc}
\hline & Inóculo & BCA & R9 & Rotm \\
\hline Parâmetros RNAr 16S & & & & \\
Cobertura - Fórmula de Good (\%) & 99,9 & 99,9 & 99,9 & 99,9 \\
Total de sequências & 88.278 & 96.791 & 83.047 & 137.129 \\
Tamanho médio das sequências (pb) & 429 & 426 & 438 & 435 \\
Total de OTUs & 47 & 73 & 60 & 55 \\
Singletons & 11 & 9 & 9 & 5 \\
Total OTUs após remoção de singletons & 36 & 64 & 51 & 50 \\
Índices ecológicos & & & & \\
Shannon (H) & 0,94 & 1,77 & 1,64 & 1,74 \\
Dominância (D) & 0,50 & 0,24 & 0,28 & 0,24 \\
\hline
\end{tabular}

Por meio da análise de cobertura (Fórmula de Good) estimou-se a proporção de sequências representativas, ou seja, mais de 99,9\% de todas as populações microbianas foram acessadas, o que é indicativo de ótima cobertura das populações nas amostras.

De acordo com os índices ecológicos, verificou-se para o índice de Shannon, menor diversidade para a amostra do inóculo $(0,94)$ concomitante com maior índice de Dominância $(0,50)$, o que significou que a abundância relativa do inóculo ficou concentrada em menor número de espécies (Clostridium bifermentans 62,69\% e Bacillus coagulans 31,67\%). Em contraste, observou-se maior índice de diversidade (1,77 1,64 e 1,74) e menor dominância $(0,24,0,28$ e 0,24$)$ para as bactérias do BCA, R9 e Rotm, respectivamente. Nessas amostras, a abundância relativa de espécies bacterianas foi mais equitativa do que aquelas do inóculo (Figura 5.25). 


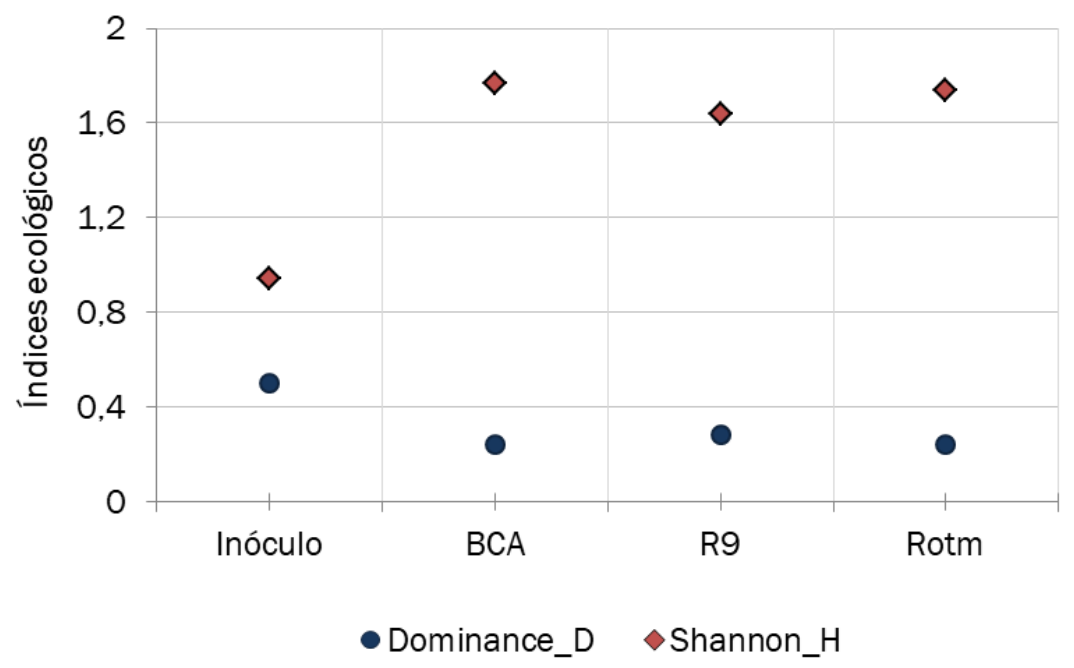

Figura 5.25: Índices ecológicos para amostra do inóculo, bagaço de cana-de-açúcar autoclavado (BCA), R9 (5,0 g BCA/L e pH 6,0) e Rotm (7,0 g BCA/L e pH 7,2).

As bactérias identificadas foram agrupadas em 201 OTUs com representantes pertencentes aos filos Firmicutes, Proteobacteria e Bacteroidetes (Figura 5.26). Para a amostra do inóculo e BCA verificou-se predominância de representantes pertencentes ao filo Firmicutes (96,06 e 98,12\%, respectivamente). Na amostra do R9, além de Firmicutes (64,06\%), foram também identificadas bactérias pertencentes ao filo Proteobacteria (35,54\%). Já para as condições do Rotm foram identificadas bactérias pertencentes aos filos Bacteroidetes (55,33\%), Proteobacteria (28,50\%) e Firmicutes (16,16\%). 


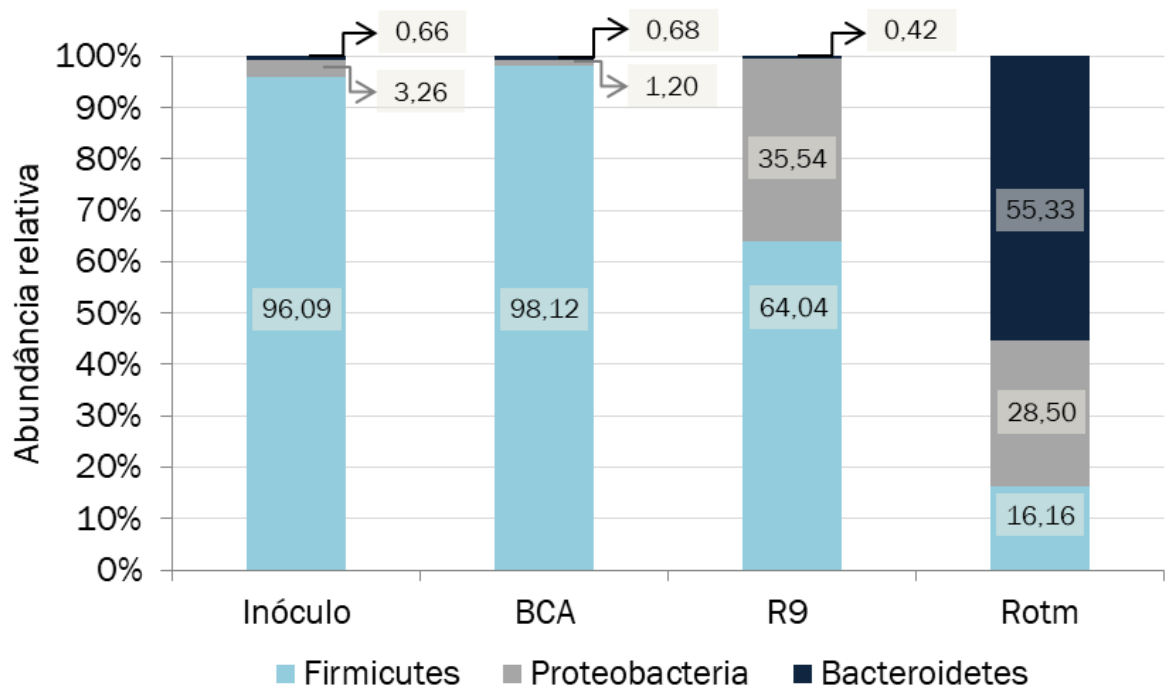

Figura 5.26: Abundância relativa (\%) de representantes pertencentes aos filos do Domínio Bacteria da amostra do inóculo, bagaço de cana-de-açúcar autoclavado (BCA) e reatores $\mathrm{R9}(5,0 \mathrm{~g}$ BCA/L e pH 6,0) e Rotm $(7,0 \mathrm{~g}$ BCA/L e pH 7,2).

Em relação ao filo Firmicutes foram identificadas bactérias pertencentes a quatro famílias, Bacillaceae, Lactobacillaceae, Paenibacillaceae e Clostridiaceae. Todavia, para o filo Proteobacteria e filo Bacteroides foram identificadas bactérias pertencentes a uma família de cada, Enterobacteriaceae e Bacteroidaceae, respectivamente (Tabela 5.10).

Representantes pertencentes ao filo Firmicutes estão relacionados com aquelas bactérias produtoras de hidrogênio, como por exemplo, famílias Clostridiaceae e Bacillaceae. Representantes pertencentes ao filo Proteobacteria, com destaque para a família Enterobacteriaceae, e filo Bacteroidetes estão também relacionadas com espécies produtoras de hidrogênio (Wirth et al., 2012; Cisneros-Pérez et al., 2015). 
Tabela 5.10: Filogenia das bactérias sequenciadas das amostras inóculo, BCA, R9 e Rotm.

\begin{tabular}{|c|c|c|c|c|c|c|c|}
\hline \multirow{2}{*}{ Filo } & \multirow{2}{*}{ Classe } & \multirow{2}{*}{ Família } & \multirow{2}{*}{ Espécie } & Inóculo & $\mathrm{BCA}$ & R9 & Rotm \\
\hline & & & & \multicolumn{4}{|c|}{ Abundância relativa $(\%)$} \\
\hline \multirow{10}{*}{ Firmicutes } & \multirow{5}{*}{ Bacilli } & \multirow{2}{*}{ Bacillaceae } & Bacillus coagulans & 31,67 & 0,30 & 0,20 & 0,15 \\
\hline & & & Bacillus djibelorensis & 0,10 & 0,05 & 0,03 & 2,91 \\
\hline & & Lactobacilliaces & Lactobacillus paracasei & 0,32 & 0,25 & 37,50 & 0,15 \\
\hline & & \multirow{2}{*}{ Paenibacillaceae } & Paenibacillus graminis & 0,12 & 8,10 & 0,05 & 0,05 \\
\hline & & & Paenibacillus timonensis & 0,03 & 3,57 & 0,03 & 0,01 \\
\hline & \multirow{5}{*}{ Clostridia } & \multirow{5}{*}{ Clostridiaceae } & Clostridium cellulolyticum & 0,22 & 5,69 & 3,91 & 7,87 \\
\hline & & & Clostridium sartagoforme & 0,40 & 14,63 & 13,46 & 0,31 \\
\hline & & & Clostridium sp. & 0,16 & 0,30 & 4,62 & 0,07 \\
\hline & & & Clostridium bifermentans & 62,69 & 31,91 & 1,99 & 3,32 \\
\hline & & & Clostridium cellobioparum & 0,32 & 32,29 & 0,70 & 1,08 \\
\hline \multirow{2}{*}{ Proteobacteria } & \multirow{2}{*}{ Gammaproteobacteria } & \multirow{2}{*}{ Enterobacteriaceae } & Enterobacter aerogenes & 2,71 & 0,63 & 1,07 & 27,72 \\
\hline & & & Escherichia hermannii & 0,49 & 0,40 & 34,32 & 0,60 \\
\hline \multirow{2}{*}{ Bacteroidetes } & \multirow{2}{*}{ Bacteroidia } & \multirow{2}{*}{ Bacteroidaceae } & Bacteroides sp. & 0,27 & 0,27 & 0,22 & 37,35 \\
\hline & & & Bacteroides xylanolyticus & 0,38 & 0,41 & 0,21 & 17,98 \\
\hline
\end{tabular}

(R9: 5,0 g BCA/L e pH 6,0 e Rotm: 7,0 g BCA/L e pH 7,2)

$\mathrm{O}$ tamanho das barras em verde proporcional à abundância relativa de cada espécie. 
Para o inóculo fermentativo, as bactérias identificadas com maior abundância relativa foram similares a: Clostridium bifermentans (62,69\%), Bacillus coagulans $(31,67 \%)$ e Enterobacter aerogenes (2,71\%). Para o BCA foram identificadas bactérias similares a $C$. cellobioparum (32,29\%), C. bifermentans (31,91\%), C. sartagoforme (14,63\%), Paenibacillus graminis $(8,10 \%)$, C. cellulolyticum (5,69\%) e P. timonensis (3,57\%). Para R9, foram identificadas bactérias similares a Lactobacillus paracasei (37,50\%), Escherichia hermannii (34,32\%) e C. sartagoforme (13,46\%), Clostridium sp. (4,54\%), C. cellulolyticum (3,91\%), C. bifermemntans $(1,99 \%)$ e E. aerogenes $(1,07 \%)$. Para Rotm, foram identificadas bactérias similares a Bacteroides sp. (37,35\%), E. aerogenes (27,72\%), Bacteroides xylanolyticus (17,98\%), C. cellulolyticum (7,87\%), C. bifermemntans (3,32\%), Bacillus djibelorensis $(2,91 \%)$ e C. cellobioparum (1,08\%). Em todas as amostras, outras bactérias (4\%) foram identificadas com abundância relativa menor que $1 \%$.

\subsubsection{Caracterização bacteriana do Inóculo Fermentativo e BCA}

No inóculo fermentativo foram identificadas bactérias semelhantes a Clostridium bifermentans (62,69\% de abundância relativa), Bacillus coagulans (31,67\%) e Enterobacter aerogenes $(2,72 \%)$. Estas bactérias pertencentes ao filo Firmicutes $(C$. bifermentans e $B$. coagulans) e Proteobacteria (E. aerogenes) são fermentativas e produtoras de hidrogênio (Nakashimada et al., 2002; Kotay e Das, 2007; Singh et al., 2010).

Bactérias do gênero Clostridium são bacilos gram-positivos, formadoras de endósporos ovais ou esféricos. A maioria das espécies produz mistura de ácidos orgânicos e álcoois como produto final da fermentação (Rainey, 2009). Singh et al. (2010) examinaram a produção de hidrogênio por meio do isolamento de Clostridium bifermentans a partir de sedimento de rio. Os autores analisaram esta espécie como produtora de hidrogênio sob diferentes condições de concentração de substrato $(2,0,4,0,6,0,8,0$ e 10,0 g/L), pH (4,5, 5,0, $5,5,6,0$ e 7,0$)$ e temperatura $\left(30,37,42\right.$ e $\left.50^{\circ} \mathrm{C}\right)$.Os autores mencionaram que o melhor rendimento foi de $16,0 \mathrm{mmol} \mathrm{H}_{2} / \mathrm{L}$, a $37^{\circ} \mathrm{C}, \mathrm{pH} 6$ e $8,0 \mathrm{~g} / \mathrm{L}$ de glicose.

Bacillus também são bacilos retos ou ligeiramente curvos, gram-positivos e formadores de endósporos, resistentes a condições adversas, e podem ser isoladas a partir do solo ou de ambientes que podem ter sido contaminados direta ou indiretamente pelo solo (Schleifer, 2010). Bacillus coagulans podem utilizar ampla gama de compostos como fonte de carbono como, por exemplo, glicose, maltose, sacarose, xilose, lactose, amido, galactose, 
manose e glicerol, o que acentua a sua capacidade de produzir hidrogênio a partir de diversos resíduos de biomassa (Valdez-Vazquez et al., 2005a, 2005b; Kotay e Das, 2007). Kotay and Das (2007) isolaram Bacillus coagulans a partir de lodo de tratamento de esgoto e investigaram quanto à sua capacidade de produzir hidrogênio a partir glicose sob a influência de diferentes valores de concentração de substrato $(0,5-2,5 \%$ p/v), $\mathrm{pH}(5,5-9,0)$ e temperatura $\left(28-40^{\circ} \mathrm{C}\right)$. $\mathrm{O}$ máximo de $0,25 \mathrm{~mol} \mathrm{H}_{2} / \mathrm{L}$, relatado por esses autores, foi obtido para $2 \%(\mathrm{p} / \mathrm{v})$ glicose, $\mathrm{pH} 6,5$ e $37^{\circ} \mathrm{C}$.

Enterobacter são bacilos gram-negativos, fermentam carboidratos com a formação de ácidos e gás (geralmente $1 \mathrm{CO}_{2}: 2 \mathrm{H}_{2}$ ) e podem ser isolados a partir de água, lodo de esgoto, vegetais e amostras de solo. Além disso, podem fermentar glicose, gluconato, frutose, galactose, sorbitol, manitol e glicerol (Nakashimada et al., 2002; Grimont e Grimont, 2005). Nakashimada et al. (2002) utilizaram cultura pura de Enterobacter aerogenes para a produção de hidrogênio a partir de glicose $(10,0 \mathrm{~g} / \mathrm{L})$, em $\mathrm{pH} 6,3$ e $37^{\circ} \mathrm{C}$ com rendimento de $0,26 \mathrm{~mol}$ $\mathrm{H}_{2} /$ L.

Assim sendo, C. bifermentans, B. coagulans e E. aerogenes são bactérias reconhecidamente produtoras de hidrogênio. O cocultivo destas espécies, conforme visto nos resultados do presente estudo, foi estratégia adequada na conversão de produtos fermentáveis em hidrogênio.

Tem-se na Figura 5.27, a imagem de microscopia óptica da coloração de Gram de amostras do inóculo. Podem-se observar bacilos Gram-positivos, e bacilos Gram-negativos.

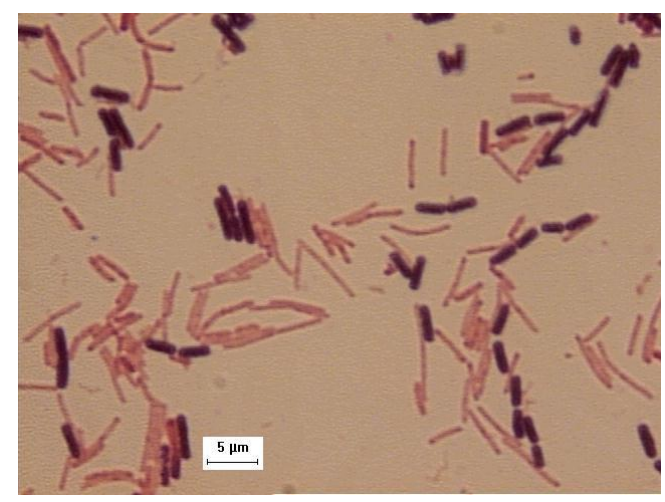

Figura 5.27: Coloração de Gram da biomassa do inóculo sob microscopia óptica.

As espécies bacterianas identificadas no inóculo com abundância relativa maior que 0,1\% estão apresentadas na Figura 5.28. 


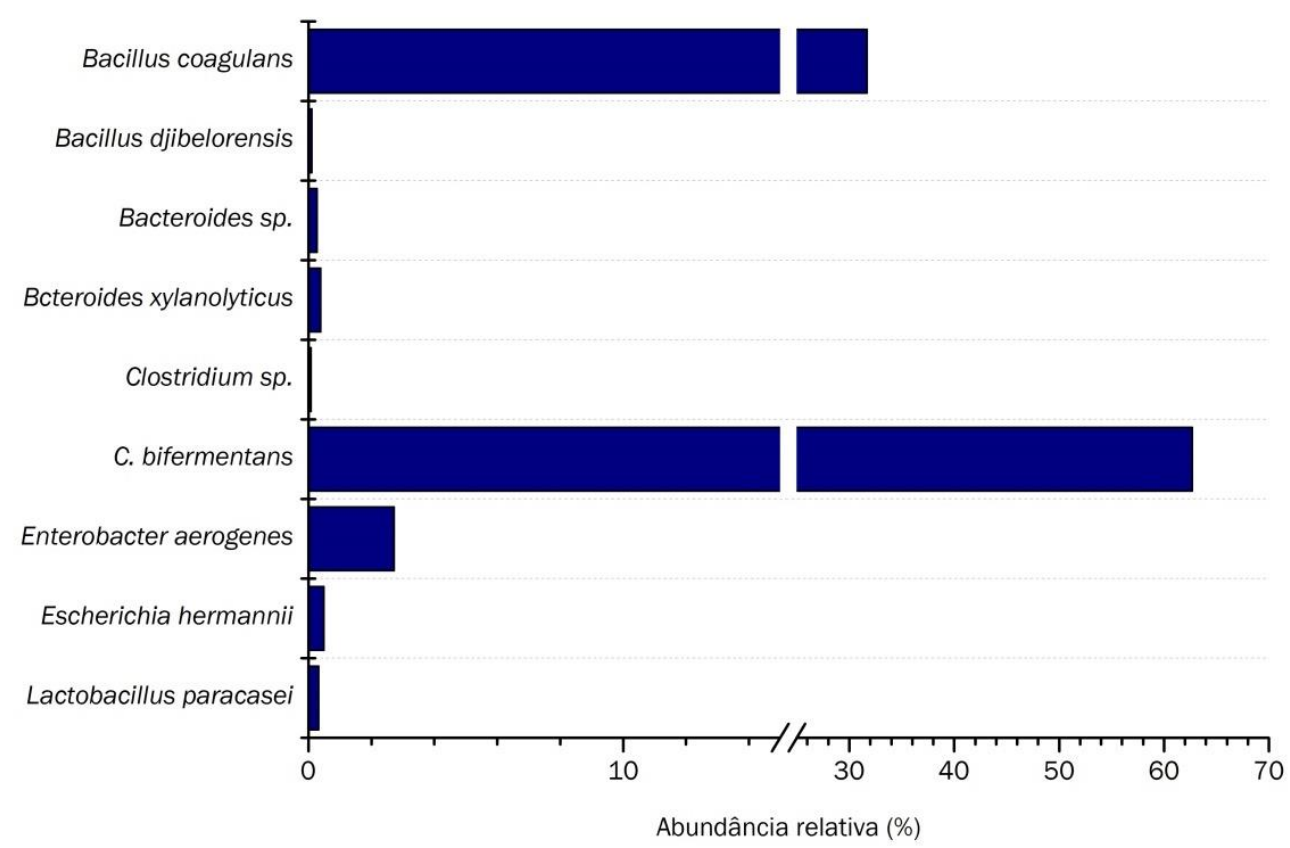

Figura 5.28: Abundância relativa das espécies bacterianas identificadas no inóculo fermentativo.

O substrato utilizado neste estudo, BCA autoclavado, também foi uma fonte de bactérias autóctones para os experimentos. Bactérias semelhantes a Clostridium spp. (84,69\% de abundância relativa) e Paenibacillus spp. (11,67\%), ambos pertencentes ao filo Firmicutes, foram identificados em amostra de BCA. Tanto, Clostridium, quanto Paenibacillus são endósporos positivos sob condições de estresse (Schleifer, 2010), característica que favoreceu a sobrevivência dessas bactérias após o pré-tratamento do BCA em autoclave. Ambos os gêneros possuem espécies produtoras de hidrogênio (Kanso et al., 2011) que, certamente, contribuíram com os resultados obtidos neste estudo.

Kanso et al. (2011) relataram que Paenibacillus possui espécies capazes de produzir grandes quantidades de hidrogênio e que podem ser isoladas a partir de solos, lodo de esgoto e fezes bovinas. As espécies de Paenibacillus identificadas no BCA podem ter sido oriundas do solo, durante o processamento da cana-de-açúcar.

As espécies de Clostridium, identificadas como autóctones do BCA, semelhantes a $C$. bifermentans $(31,91 \%$ de abundância relativa), C. cellobioparum (32,29\%), C. cellulolyticum $(5,69 \%)$ e C. sartagoforme $(14,63 \%)$ além de serem produtoras de hidrogênio, são também celulolíticas (Desvaux, 2005; Ren et al., 2007; Zhang et al., 2012; Zhang et al., 2015). Ren et al. (2007) avaliaram a produção de hidrogênio a partir de celulose com diferentes espécies de Clostridium como inóculo, dentre elas, C. cellulolyticum e C. cellobioparum. Ambas as 
espécies foram capazes de fermentar a celulose com produção de 6,2 e 4,4 mmol/L de hidrogênio, respectivamente, com 5,0 g/L e pH 6,5.

Zhang et al. (2015) estudaram outra espécie de Clostridium, C. sartagoforme, que foi isolada a partir de esterco bovino, para produção de hidrogênio. Os autores relataram a conversão direta da biomassa celulósica (haste de milho) sem pré-tratamentos e obtiveram 0,43 mol/L de hidrogênio com 15,0 g/L de substrato e $\mathrm{pH}$ 6,47. No presente estudo, diferentemente dos demais relatos, foi utilizado BCA como substrato e foram obtidos 19,84 mmol/L de hidrogênio, sob condições ideais de concentração de substrato e pH (7,0 g/L e pH 7,2), utilizando Clostridium bifermentans, Bacillus coagulans e Enterobacter aerogenes como inóculo fermentativo em associação com bactérias celulolíticas, principalmente espécies de Clostridium, autóctones de BCA.

As espécies bacterianas identificadas no BCA com abundância relativa maior que 0,1\%. estão representadas na Figura 5.29

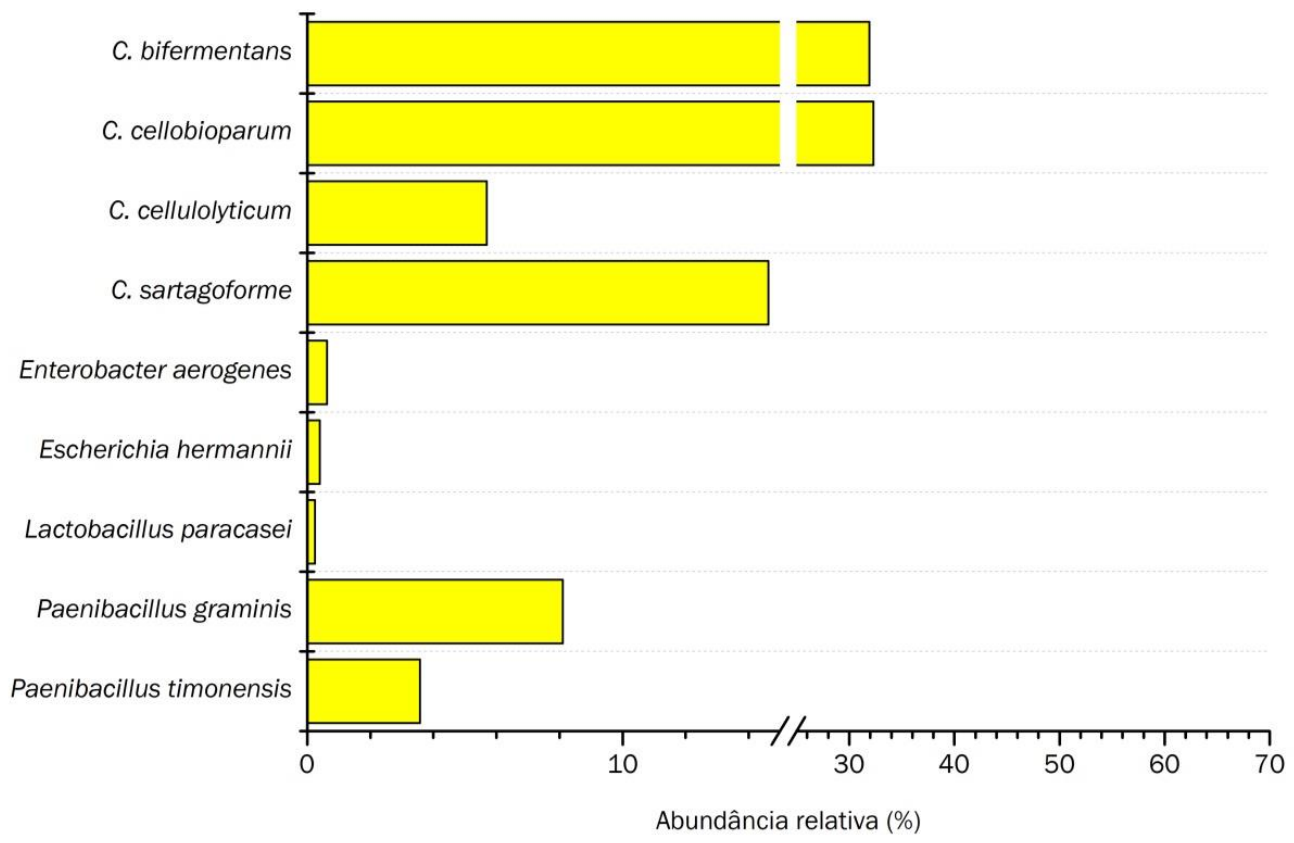

Figura 5.29: Abundância relativa das espécies bacterianas identificadas no BCA autoclavado.

A partir da caracterização filogenética bacteriana das amostras do inóculo e do BCA, pode-se observar tanto bactérias celulolíticas quanto fermentativas.

Dentre as bactérias identificadas no inóculo, com abundância relativa maior que $0,1 \%$, seis foram semelhantes a espécies produtoras de hidrogênio (Bacillus coagulans, Bacteroides xylanolyticus, C. bifermentans, L. paracasei Escherichia hermanniii e Enterocater aerogenes) 
(Grimont e Grimont, 2005; Scheutz e Strockbine, 2005; Schleifer, 2010; Song et al., 2010). Apenas para uma espécie (Bacillus djibelorensis) não foi possível, determinar suas características metabólicas.

Dentre as bactérias identificadas do BCA, seis espécies são produtoras de hidrogênio (Bacillus coagulans, Bacteroides xylanolyticus, C. bifermentans, L. paracase, Escherichia hermanniii e Enterocater aerogenes) (Grimont e Grimont, 2005; Scheutz e Strockbine, 2005; Schleifer, 2010; Song et al., 2010) e cinco, além de produtoras de hidrogênio são também celulolíticas (C. cellobioparum, C. sartagoforme e C. cellulolyticum, $P$. graminis e $P$. timonensis) (Schleifer, 2010). Pode-se observar no diagrama de Venn (Figura 5.30), a relação entre estas caracteísticas metabólicas (celulolítica/fermentativa) e as principais espécies identificadas no inóculo fermentativo e BCA autoclavado.

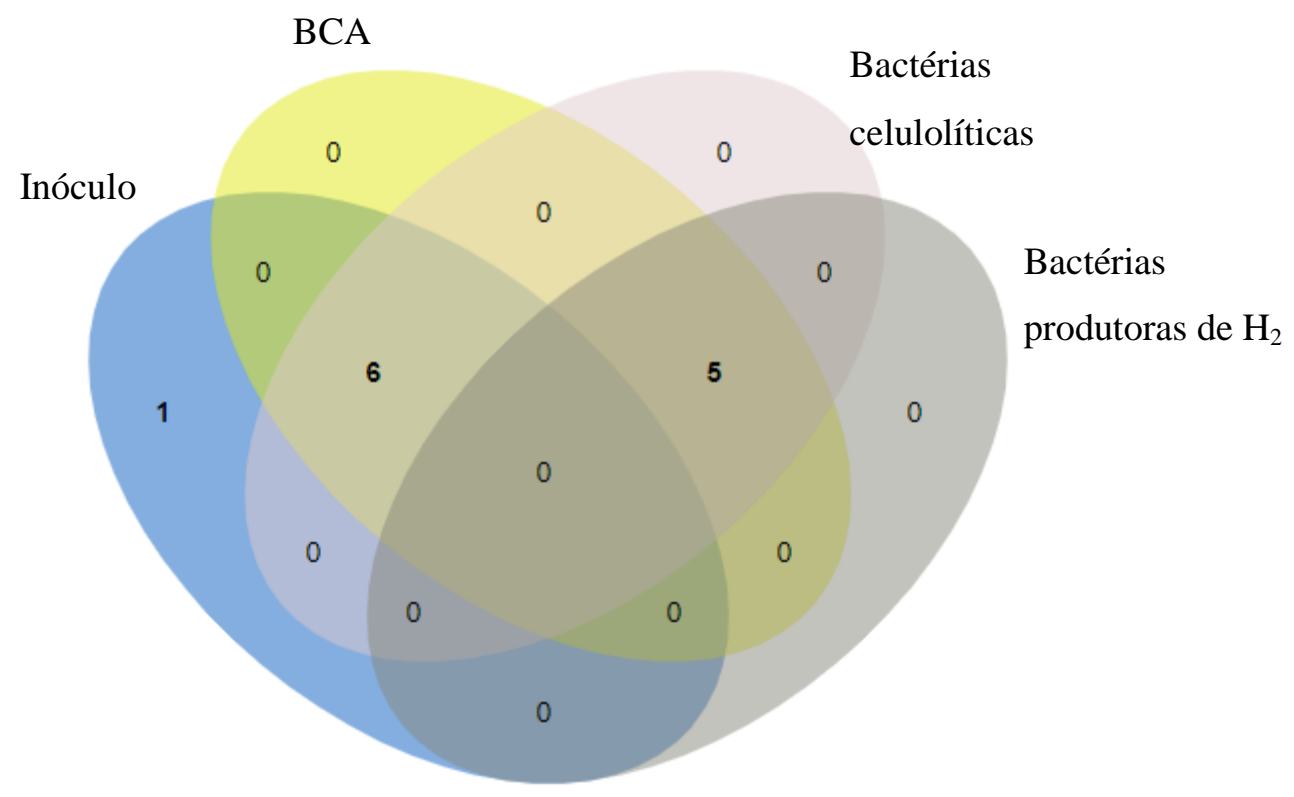

Figura 5.30: Diagrama de Venn referente a presença e ausência de espécies bacterianas celulolíticas e/ou fermentativas identificadas do inóculo fermentativo e BCA autoclavado.

\subsubsection{Caracterização bacteriana de R9 e Rotm}

O consórcio formado por bactérias oriundas do inóculo e BCA formaram comunidade capaz de converter o substrato lignocelulósico em hidrogênio, tanto nas condições de R9 (5,0 g BCA/L e pH 6,0), quanto nas condições de $\operatorname{Rotm}(7,0 \mathrm{~g} \mathrm{BCA} / \mathrm{L}$ e pH 7,2). Entretanto, as bactérias identificadas com maior abundância relativa no inóculo ( $C$. bifermentans, 62,69\% e Bacillus coagulans, 31,67\%) e aderidas no BCA (C. bifermentans, $31,91 \%$ e $C$. cellobioparum, 32,29\%) não foram favorecidas sob as condições impostas ao R9 e Rotm, uma 
vez que a abundância relativa das bactérias identificadas nas amostras dos reatores foram completamente diferentes.

Em R9, bactérias semelhantes a Lactobacillus paracasei e Escherichia hermannii foram identificas com 37,50 e 34,32\% de abundância relativa, respectivamente. Em Rotm, as principais bactérias identificadas foram semelhantes a Bacteroides sp. e Enterobacter aerogenes, com 37,35 e 27,72\% de abundância relativa, respectivamente.

L. paracasei, E. hermannii e Bacteroides sp. foram identificadas com baixa abundância relativa (menos de 0,5\%), tanto no inóculo, quanto no BCA. A mesma observação pode ser feita para representantes semelhantes a Enterobacter aerogenes identificados nas amostras do inóculo e BCA com abundância relativa de 3,0\% (Figura 5.31).
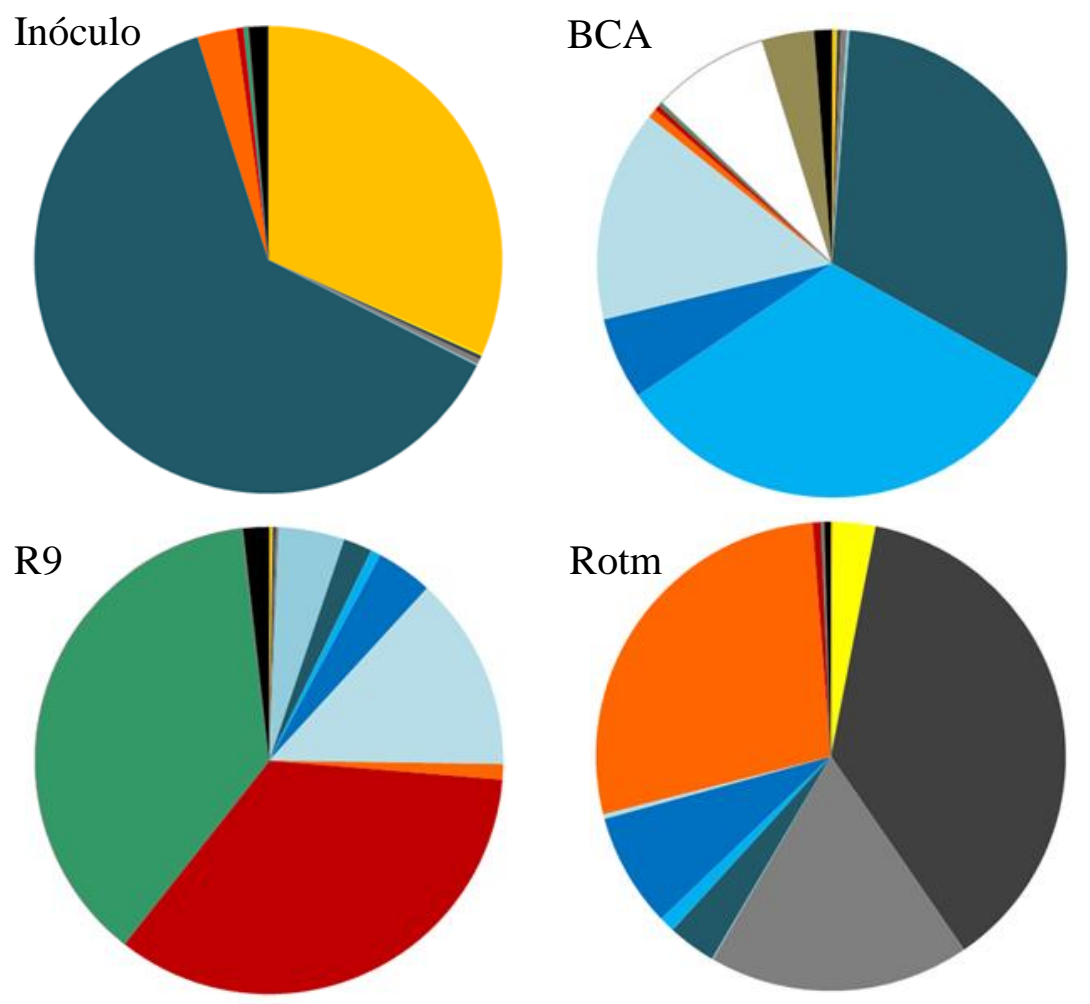

Bacillus coagulans

Bacillus djibelorensis

- Bacteroides sp.

Bcteroides xylanolyticus

Clostridium sp.

- C. bifermentans

- C. cellobioparum

c. cellulolyticum

C. sartagoforme

Enterobacter aerogenes

- Escherichia hermannii

- Lactobacillus paracasei

$\square$ Paenibacillus graminis

- P. timonensis

- Outras

Figura 5.31: Principais espécies identificadas nas amostras do Inóculo, BCA, R9 (5,0 g BCA/L e pH 6,0) e Rotm (7,0 g BCA/L e pH 7,2).

Na Tabela 5.11 estão descritos os principais gêneros e espécies, bem como as características fisiológicas das bactérias identificadas no inóculo (A), BCA (B), R9 (C) e Rotm (D). 
Tabela 5.11: Taxonomia e fisiologia das espécies bacterianas identificadas no inóculo (A), BCA (B), R9 (C) e Rotm (D) (abundância relativa maior que $0,1 \%)$

\begin{tabular}{|c|c|c|c|c|c|c|c|c|}
\hline \multirow{2}{*}{ Espécie } & \multirow{2}{*}{$\begin{array}{l}\text { Produtora } \\
\text { de } \mathrm{H}_{2}\end{array}$} & \multirow{2}{*}{ Celulolítica } & \multirow{2}{*}{$\begin{array}{l}\text { Principais açúcares } \\
\text { fermentados }\end{array}$} & \multirow{2}{*}{$\begin{array}{l}\text { Principais ácidos orgânicos } \\
\text { produzidos }\end{array}$} & \multicolumn{4}{|c|}{ Abundância relativa (\%) } \\
\hline & & & & & (A) & (B) & (C) & (D) \\
\hline Bacillus coagulans $^{(1)}$ & + & - & $\begin{array}{l}\text { Galactose, glicose, manose, } \\
\text { xilose }\end{array}$ & Acético, butírico & 31,67 & 0,30 & 0,20 & 0,15 \\
\hline Bacillus djibelorensis ${ }^{(2)}$ & $*$ & $* *$ & $\begin{array}{c}\text { Glicose e outros carboidratos } \\
\text { fermentáveis }\end{array}$ & Acético, butírico & 0,10 & 0,05 & 0,03 & 2,91 \\
\hline Bacteroides sp. ${ }^{(3)}$ & $*$ & $* *$ & \multirow{2}{*}{$\begin{array}{l}\text { Arabinose, glicose, manose, } \\
\text { xilose, celobiose }\end{array}$} & \multirow{2}{*}{ Acético, butírico, succínico } & 0,27 & 0,27 & 0,22 & 37,35 \\
\hline Bacteroides xylanolyticus $^{(3)}$ & + & - & & & 0,38 & 0,41 & 0,21 & 17,98 \\
\hline Clostridium sp. $^{(4)}$ & $*$ & $* *$ & Variável & Variável & 0,09 & 0,17 & 4,54 & 0,06 \\
\hline C. bifermentans ${ }^{(4)}$ & + & - & Glicose & $\begin{array}{c}\text { Butírico, isovalérico, propiônico, } \\
\text { valérico }\end{array}$ & 62,69 & 31,91 & 1,99 & 3,32 \\
\hline C. cellobioparum $^{(4)}$ & + & + & Celulose & Acético, fórmico, lático & 0,00 & 32,29 & 0,70 & 1,08 \\
\hline C. cellulolyticum ${ }^{(4)}$ & + & + & $\begin{array}{l}\text { Arabinose, glicose, xilose, } \\
\text { celulose, celobiose, }\end{array}$ & Acético, fórmico, lático & 0,00 & 5,69 & 3,91 & 7,87 \\
\hline C. sartagoforme ${ }^{(4)}$ & + & + & $\begin{array}{c}\text { Glicose, xilose, celulose, } \\
\text { celobiose }\end{array}$ & Acético, butírico, fórmico & 0,00 & 14,63 & 13,46 & 0,31 \\
\hline Enterobacter aerogenes $^{(5)}$ & + & - & $\begin{array}{l}\text { Arabinose, glicose, lactose, } \\
\text { manose, celobiose }\end{array}$ & Acético, butírico, propiônico & 2,72 & 0,63 & 1,07 & 27,72 \\
\hline Escherichia hermannii $^{(6)}$ & + & - & $\begin{array}{l}\text { Arabinose, glicose, manose, } \\
\text { xilose, celobiose }\end{array}$ & Acético, fórmico, lático & 0,49 & 0,40 & 34,32 & 0,60 \\
\hline Lactobacillus paracase $^{(7)}$ & - & - & Glicose, sacarose, celobiose & Acético, fórmico, lático & 0,32 & 0,25 & 37,50 & 0,15 \\
\hline Paenibacillus sp. ${ }^{(8)}$ & $*$ & $* *$ & Glicose, xilose, celulose & Acético, fórmico & 0,03 & 11,67 & 0,08 & 0,06 \\
\hline Outras & & & & & 1,34 & 1,23 & 1,79 & 0,44 \\
\hline
\end{tabular}

(A): Inóculo fermentativo, (B): BCA (bagaço de cana-de-açúcar autoclavado), (C): R9, 5,0g BCA/L e pH 6,0, (D) Rotm, 7,0 g BCA/L e pH 7,2.

* Há espécies produtoras e não produtoras de hidrogênio, ** há espécies celulolíticas e não celulolíticas

${ }^{(1)}$ (Kotay e Das, 2007), ${ }^{(2)}$ de acordo com Bacillus sp. (Schleifer, 2010), ${ }^{(3)}$ (Song et al., 2010), ${ }^{(4)}$ (Schleifer, 2010; Zhang et al, 2015), ${ }^{(5)}($ Lakshmidevi e Muthukumar, 2010), ${ }^{(6)}$ (Scheutz e Strockbine, 2005), ${ }^{(7)}\left(\right.$ Schleifer, 2010), ${ }^{(8)}$ (Schleifer, 2010). 
Em R9, além de L. paracasei e E. hermannii, também foram identificadas bactérias semelhantes a $C$. sartagoforme $(13,46 \%$ de abundância relativa), C. cellulolyticum $(3,91 \%)$ e C. bifermentants $(1,99 \%)$.

C. sartagoforme e C. cellulolyticum são espécies celulolíticas (Rainey, 2009) e, provavelmente, foram as responsáveis pela hidrólise da celulose do BCA em açúcares solúveis. A bioconversão dos açúcares identificados nas amostras de R9, (arabinose, galactose, glicose, manose e xilose), estão relacionada às características fisiológicas de $L$. paracasei, E. hermannii, C. sartagoforme, C. cellulolyticum e C. bifermentants, bactérias identificadas em amostras de R9.

Bacteroides sp. e C. cellulolyticum, que foram bactérias identificadas com baixa abundância relativa $(0,43$ e 3,91\%, respectivamente), podem ter sido responsáveis pela produção dos principais ácidos orgânicos em R9; ou seja, succínico e isovalérico $(1,27$ e 1,01 $\mathrm{g} / \mathrm{L}$, respectivamente).

L. paracasei é uma espécie heterofermentativa facultativa, onde os principais produtos da fermentação de hexoses e pentoses são ácido lático, ácido acético e etanol (Schleifer, 2010). O ácido lático, certamente produzido por L. paracasei, não foi quantificado em amostras do R9. Provavelmente, bactérias semelhantes a Clostridium, tais como $C$. beijerinckii, C. butyricum, C. diolis e C. tyrobutyricum, foram capazes de converter o ácido lático em ácido butírico com a concomitante produção de hidrogênio (Matsumoto e Nishimura, 2007; Wu et al., 2012).

Espécies de Lactobacillus, como L. paracasei, identificada neste estudo, são produtoras de bacteriocinas, que são pequenos peptídeos com atividade bactericida que atuam contra diversas bactérias Gram positivas, incluindo aquelas semelhantes a Clostridium (Cleveland et al., 2001; Noike et al., 2002; Valdez-Vazquez e Poggi-Varaldo, 2009; Miao et al., 2014). Noike et al. (2002) reportaram que a adição de bactérias láticas ou de seus metabólitos em culturas de Clostridium, resultou no decrescimo ou inibição da produção de hidrogênio.

C. bifermentans foi identificado com alta abundância $(62,69 \%)$ relativa no inóculo fermentativo deste estudo, assim como C. bifermentans e C. cellobioparum foram identificados no BCA com abundância relativa de 31,91 e 32,29\%, respectivamente. Em contrapartida, em R9 observou-se significativa diminuição na abundancia relativa de ambas espécies (1,99 e 0,70\% de C. biferementans e C. cellobioparum, respectivamente), 
possivelmente devido a ação de bacteriocinas produzidas por Lactobacillus, uma vez que a abundância relativa de $L$. paracasei, produtor de bactericida, aumentou significativamente em R9 $(37,5 \%)$ em relação ao consórcio fermentativo $(0,49 \%)$ e ao BCA $(0,40 \%)$.

Entretanto, a identificação de bactérias semelhantes a Clostridium e Lactobacillus em reatores de produção de hidrogênio tem sido relatada em trabalhos com significativos valores de produção de hidrogênio (Yang et al., 2007; Perna et al., 2013; Gomez-Romero et al., 2014). Yang et al. (2007), por exemplo, identificaram Lactobacillus sp. (50\% de abundância relativa) e Clostridium sp. (5\% de abundância relativa) em reatores em batelada com efluente sintético de processamento de queijo como substrato para produção de hidrogênio. No presente estudo, Clostridium sp., cuja abundância relativa no inóculo fermentativo e no BCA foi baixa (0,09 e 0,17\%, respectivamente), foi favorecido em R9, verificado pelo aumento de sua abundância relativa $(4,54 \%)$ nesta condição. Pode-se observar também que, em R9, a abundância relativa de $C$. sartagoforme manteve-se próxima daquela verificada no BCA $(13,46$ e 14,63\%, respectivamente), indicando que tal espécie não foi afetada significativamente pelas bactérias láticas e seus metabólitos.

Desta forma, em R9, Lactobacillus paracasei e Clostridium sp. podem ter sido relacionados, tanto com a produção de hidrogênio $(17,89 \mathrm{mmol} / \mathrm{L})$, quanto com produção de ácido acético $(0,78 \mathrm{~g} / \mathrm{L})$.

E. hermannii, também identificado em R9 (34,32\% de abundância relativa), pode utilizar a maioria dos carboidratos fermentáveis como arabinose, glicose, manose e xilose e também celobiose (Scheutz e Strockbine, 2005). E. hermannii já foi isolada a partir de amostras de alimentos (Brenner et al., 1982) e de amostras ambientais, como lodo de estação de tratamento de águas residuais industriais (Kiernicka et al., 1999) e chorume de aterro sanitário (Shin et al., 2007). Apesar de ser uma espécie produtora de hidrogênio (Scheutz e Strockbine, 2005), não foram encontrados relatos na literatura de E. hermannii como inóculo em reatores de produção de hidrogênio. Neste estudo, E. hermannii, identificado, tanto em BCA, quanto no inoculo fermentativo, foi favorecida pelos açúcares liberados por bactérias celulolíticas e, provavelmente, foi responsável pela produção de hidrogênio em R9 (17,86 $\mathrm{mmol} / \mathrm{L})$.

As principais espécies bacterianas, com abundância relativa maior que $0,1 \%$, identificadas em R9 estão representadas na Figura 5.32. 


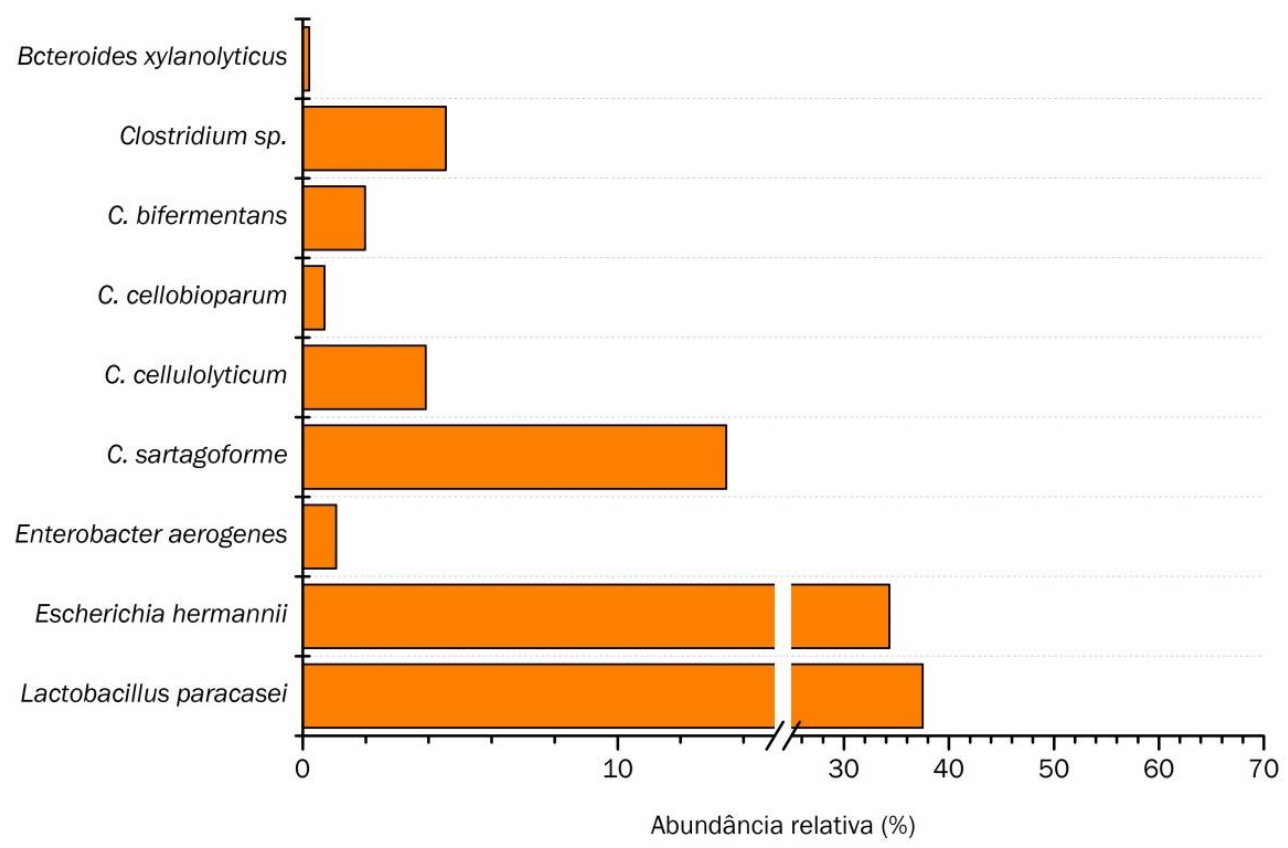

6,0).

Figura 5.32: Abundância relativa das espécies bacterianas identificadas em $\mathrm{R9}(5,0 \mathrm{~g}$ BCA/L e pH

Nas amostras de Rotm, mais de 90\% das bactérias identificadas foram relacionadas com a produção de hidrogênio. Sob as condições de 7,0 g BCA/L e pH 7,2, C. cellulolyticum (7,87 \% de abundância relativa), C. cellobioparum $(1,08 \%)$ e C. sartagoforme $(0,31 \%)$ foram as principais bactérias celulolíticas identificadas e, provavelmente, hidrolisaram a celulose do BCA em açúcares solúveis, como arabinose, galactose, glicose e xilose quantificados no presente estudo.

Bactérias do gênero Bacteroides, pertencente ao filo Bacteroidetes, predominantes em Rotm (55,33\% de abundância relativa), são bioquimicamente e fisiologicamente heterogêneos, com crescimento ótimo a $37^{\circ} \mathrm{C}$ e $\mathrm{pH}$ próximo de 7,0 (Song et al., 2010), características impostas no Rotm. Essas bactérias podem ter sido favorecidas, além das condições de temperatura e $\mathrm{pH}$, pelos carboidratos liberados por bactérias celulolíticas e, provavelmente, contribuíram com a produção principalmente de ácido succínico $(1,21 \mathrm{~g} / \mathrm{L})$ e butírico (1,33 g/L) em Rotm. Bacteroides xylanolyticus, identificado em Rotm, pode fermentar xilose e outros açúcares solúveis como glicose, celobiose, manose e arabinose em hidrogênio (Song et al., 2010). Bacteroides têm sido descritos como importantes produtores de hidrogênio em culturas contendo substrato celulósico (Gupta et al., 2014b) e, provavelmente, desempenharam papel importante nas vias fermentativas no Rotm. 
Outra bactéria identificada com alta abundância relativa $(27,72 \%)$ em Rotm foi Enterobacter aerogenes, favorecida pelos açúcares solúveis presentes, contribuiu com a produção de hidrogênio $(19,84 \mathrm{mmol} / \mathrm{L})$ e ácidos acético $(1,57 \mathrm{~g} / \mathrm{L})$, butírico $(1,33 \mathrm{~g} / \mathrm{L})$ e propiônico $(0,85 \mathrm{~g} / \mathrm{L})$ no experimento.

As principais espécies bacterianas, com abundância relativa maior que $0,1 \%$, identificadas em Rotm estão apresentadas na Figura 5.33.

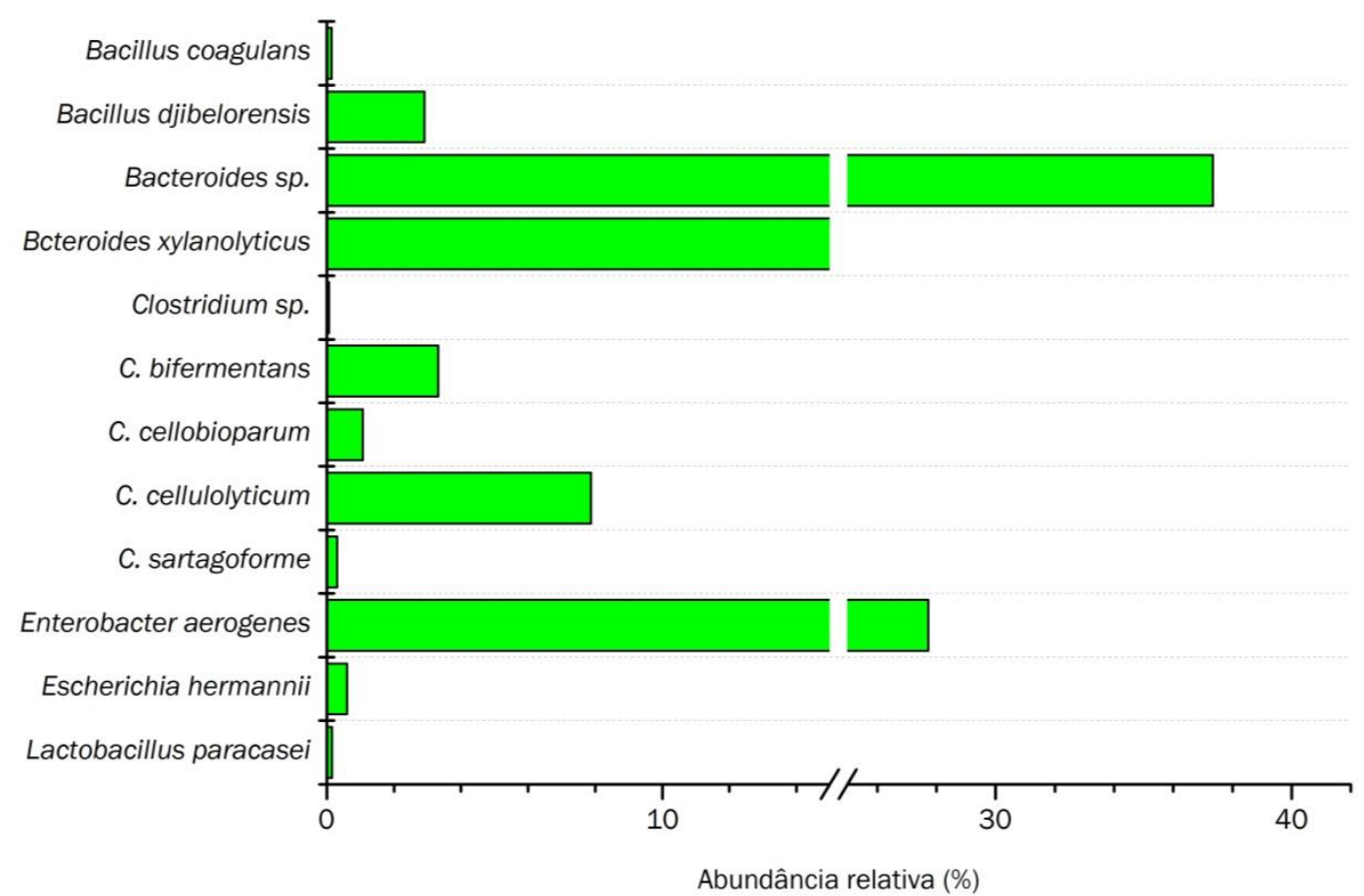

pH 7,2).

Figura 5.33: Abundância relativa das espécies bacterianas identificadas em Rotm (7,0 g BCA/L e

De fato, as diferentes condições físico-químicas impostas aos experimentos de produção de hidrogênio influenciaram a seleção de certas populações bacterianas em relação a outras. Provavelmente, as condições impostas de 5,0 g BCA/L e pH 6,0 (R9) favoreceram principalmente $L$. paracasei e E. hermannii, enquanto, em Rotm, 7,0 g/L de BCA e pH 7,2 favoreceram outras bactérias, semelhantes a Bacteroides sp. e E. aerogenes. É importante notar que, mesmo em menor abundância relativa, espécies de Clostridium foram identificadas, tanto em R9 (24,58\%), quanto em Rotm $(12,65 \%)$ e, provavelmente, contribuíram com a conversão direta do BCA em hidrogênio e ácidos orgânicos. 


\subsubsection{Análise comparativa entre os reatores de produção de Hidrogênio}

Os principais gêneros e espécies bacterianas identificados nas amostras do inóculo fermentativo, BCA, R9 e Rotm, com abundância relativa maior que 1\%, podem ser visualizados no ideograma circular (Figura 5.34).

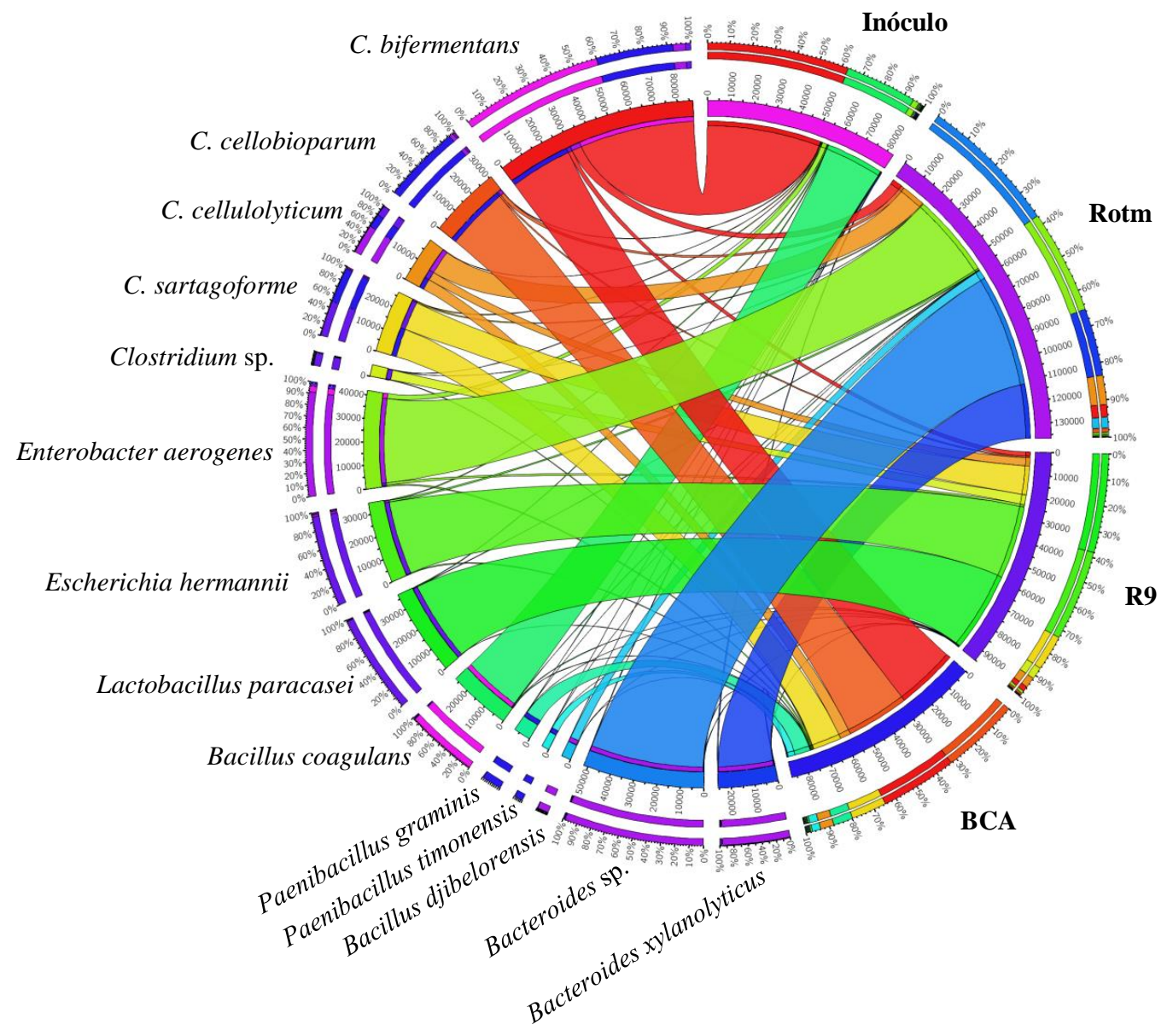

Figura 5.34 Ideograma circular "Circos". Relação de prevalência dos gêneros e espécies mais frequentes nas amostras do inóculo, BCA, $\mathrm{R9}(5,0 \mathrm{~g} \mathrm{BCA} / \mathrm{L}$ e pH 6,0) e Rotm $(7,0 \mathrm{~g} \mathrm{BCA} / \mathrm{L}$ e pH 7,2), onde o círculo externo representa a abundância relativa em função do número de leituras.

Os principais resultados observados, após 15 dias de monitoramento dos reatores do planejamento fatorial (R1 a R10) e reator com as condições otimizadas (Rotm), estão resumidos na Tabela 5.12: Resultados do monitoramento dos reatores do planejamento fatorial. 
Tabela 5.12: Resultados do monitoramento dos reatores do planejamento fatorial.

\begin{tabular}{|c|c|c|c|c|c|c|c|c|c|c|c|}
\hline Parâmetros & R1 & R2 & R3 & $\mathrm{R} 4$ & R5 & R6 & R7 & R8 & R9 & R10 & Rotm \\
\hline BCA (g/L) & 2,0 & 2,0 & 8,0 & 8,0 & 0,8 & 9,2 & 5,0 & 5,0 & 5,0 & 5,0 & 7,0 \\
\hline $\mathrm{pH}$ inicial & 5,0 & 7,0 & 5,0 & 7,0 & 6,0 & 6,0 & 4,6 & 7,4 & 6,0 & 6,0 & 7,2 \\
\hline $\mathrm{pH}$ final & 4,1 & 6,5 & 3,6 & 5,7 & 5,3 & 5,4 & 3,8 & 6,1 & 5,8 & 5,6 & 6,0 \\
\hline $\mathrm{H}_{2}(\mathrm{mmol} / \mathrm{L})$ & 1,64 & 12,79 & 7,31 & 24,06 & 6,79 & 13,64 & 0,33 & 20,13 & 17,86 & 18,86 & 19,84 \\
\hline$R m(\mathrm{mmol} / \mathrm{L} . \mathrm{d})$ & 0,41 & 1,74 & 0,59 & 4,57 & 0,64 & 2,18 & 0,03 & 2,31 & 2,79 & 2,30 & 4,07 \\
\hline$\lambda(\mathrm{d})$ & 0,2 & 3,8 & 1,1 & 2,7 & 0,2 & 2,0 & 0 & 2,1 & 1,5 & 2,4 & 2,5 \\
\hline Glicose $(\mathrm{mg} / \mathrm{L})$ & 0 & 13,95 & 0 & 0 & 0 & 17,80 & 0 & 0 & 119,61 & 16,76 & 11,27 \\
\hline Xilose (mg/L) & 0 & 0 & 27,81 & 0 & 0 & 0 & 0 & 0 & 0 & 33,78 & 0 \\
\hline Galactose $(\mathrm{mg} / \mathrm{L})$ & 0 & 18,33 & 0 & 0 & 0 & 20,58 & 0 & 0 & 0 & 0 & 0 \\
\hline Manose (mg/L) & 0 & 0 & 0 & 0 & 502,86 & 0 & 0 & 0 & 320,57 & 0 & 0 \\
\hline Arabinose $(\mathrm{mg} / \mathrm{L})$ & 548,46 & 136,41 & 1415,26 & 70,48 & 307,93 & 264,45 & 94,42 & 1372,45 & 321,52 & 86,09 & 120,37 \\
\hline Ac. Butírico $(\mathrm{g} / \mathrm{L})$ & 0,7 & 1,4 & 1,6 & 1,9 & 1,8 & 1,9 & 1,2 & 1,9 & 0,8 & 1,0 & 1,33 \\
\hline Ac. Succínico (g/L) & 1,06 & 1,09 & 1,38 & 1,36 & 1,38 & 1,16 & 1,23 & 1,41 & 1,27 & 1,65 & 1,21 \\
\hline Ac. Isovalérico $(\mathrm{g} / \mathrm{L})$ & 0,92 & 0,97 & 1,33 & 1,04 & 1,19 & 0,99 & 1,04 & 1,22 & 1,01 & 1,32 & 0,61 \\
\hline Ac. Propiônico (g/L) & 0,74 & 0,16 & 1,22 & 0,67 & 0,71 & 0,20 & 0,84 & 0,23 & 0,57 & 0,88 & 0,85 \\
\hline Ac. Acético (g/L) & 0,71 & 0,91 & 1,06 & 1,05 & 0,88 & 0,97 & 0,75 & 1,11 & 0,78 & 0,95 & 1,57 \\
\hline Etanol $(\mathrm{g} / \mathrm{L})$ & 0,12 & 0,10 & 0,10 & 0,11 & 0,10 & 0,10 & 0,04 & 0,12 & 0,03 & 0,06 & 0,21 \\
\hline DQO (g/L) & 3,27 & 4,00 & 4,25 & 6,00 & 4,66 & 6,53 & 5,34 & 6,95 & 4,67 & 6,17 & 5,63 \\
\hline MS removida (\%) & 6,8 & 10,7 & 10,6 & 11,7 & 11,3 & 11,5 & 7,6 & 10,2 & 20,3 & 21,8 & 20,7 \\
\hline
\end{tabular}


De acordo com os dados expostos na Tabela 5.12, pode-se observar que houve pouca variação em relação ao pH inicial e final dos reatores (maior variação foi em R3, de 5,0 para 3,6). A manutenção do $\mathrm{pH}$ pode ter sido decorrente do meio de cultura utilizado (PCS), que continha 2,0 g/L de carbonato de cálcio. Esse agente tamponante pode ter favorecido o processo fermentativo, evitando a brusca diminuição do $\mathrm{pH}$ do sistema, uma vez que este composto pode neutralizar os efeitos da produção de ácidos orgânicos (Dionisi e Silva, 2016).

A maior produção de hidrogênio $(24,06 \mathrm{mmol} / \mathrm{L})$, conforme já relatado anteriormente, foi obtida em R4 com 8,0 g BCA/L e pH 7,0. Nesta condição 6,42 g/L de ácidos orgânicos foram produzidos, sendo o ácido succínico o principal composto orgânico observado (1,36 g/L).

Nos reatores do ponto central (R9 e R10) observou-se 17,86 e 18,86 mmol $\mathrm{H}_{2} / \mathrm{L}$, além de 4,78 e 6,25 g/L de ácidos orgânicos, respectivamente. Nas condições de R9 e R10 (7,0 g BCA/L e pH 7,2), o principal ácido orgânico observado também foi o succínico $(1,27$ e 1,65 g/L, respectivamente). O ácido succínico é um dos principais compostos produzidos por espécies de Bacteroides (Song et al., 2010). Estas bactérias foram identificadas nas amostras de R9 e Rotm com 0,43 e 55,33 \% de abundância relativa, respectivamente.

Concentrações variadas de manose, galactose, xilose e arabinose foram observadas ao longo do tempo de monitoramento de todos os reatores, indicando a efetiva hidrólise da celulose e hemicelulose constituintes do BCA.

O melhor resultado de remoção de matéria seca (MS) nos reatores do ponto central pode ter sido devido ao metabolismo de $C$. sartagoforme e $C$. cellulolyticum, espécies celulolíticas (Rainey, 2009) identificadas nas amostras de R9.

Em Rotm, o reator com as condições otimizadas com 7,0 g BCA/L e pH 7,2, a remoção de MS foi bem próxima dos reatores do ponto central $(20,7 \%)$ e, assim como em R9, bactérias celulolíticas foram identificadas semelhantes a Bacteroides e Clostridium, as quais podem ter hidrolisado o BCA em açúcares, ácidos orgânicos e hidrogênio.

Em Rotm, foram produzidos 19,84 mmol $\mathrm{H}_{2} / \mathrm{L}$ e 5,9 g/L de ácidos orgânicos. Diferentes dos demais reatores, o ácido acético foi o principal composto orgânico observado, seguido de succínico e isobutírico. Estes ácidos orgânicos observados são 
condizentes com os principais produtos do metabolismo de Bacteroides sp., identificados em Rotm com 37,35\% de abundância relativa.

Em análise conjunta dos principais produtos da fermentação do BCA e também da MS removida em todos os reatores, pode-se observar que as condições de Rotm (7,0 g BCA/L e pH 7,2) favoreceram a produção de hidrogênio $(19,84 \mathrm{mmol} / \mathrm{L})$, a formação de ácido acético (1,57 g/L) e remoção de MS (20,7\%).

De acordo com a análise de delineamento por composto central e metodologia de superfície de resposta foi possível avaliar efeito da concentração de substrato e $\mathrm{pH}$ nas respostas produção de hidrogênio, ácido succínico e também sobre a remoção de MS (Tabela 5.13). Os respectivos modelos foram bem representativos, com valores de $\mathrm{R}^{2}$ 0,93, 0,81, 0,97, e 0,99 para produção de hidrogênio, velocidade de produção de hidrogênio, produção de ácido succínico e remoção de MS, respectivamente.

Os modelos de produção de hidrogênio e de remoção de matéria seca foram validados com precisão de 85,9 e $100 \%$, respectivamente.

Tabela 5.13 Respostas do planejamento fatorial para concentração de substrato e pH.

\begin{tabular}{|c|c|c|c|c|c|}
\hline Parâmetro & $\begin{array}{l}\text { BCA }(\mathrm{g} / \mathrm{L}) \\
\text { otimizado }\end{array}$ & pH otimizado & Valor previsto & Valor obtido & $\begin{array}{c}\text { Precisão do } \\
\text { modelo }\end{array}$ \\
\hline $\mathrm{H}_{2}(\mathrm{mmol} / \mathrm{L})$ & 7,0 & 7,2 & 23,10 & 19,84 & $85,9 \%$ \\
\hline Modelo & \multicolumn{5}{|c|}{$17,96+3,38 \mathrm{x}_{1}-3,78 \mathrm{x}_{1}^{2}+6,91 \mathrm{x}_{2}-3,35 \mathrm{x}_{2}^{2}+1,39 \mathrm{x}_{1} \mathrm{x}_{2} \quad\left(\mathrm{R}^{2}=0,93\right)$} \\
\hline$R m(\mathrm{mmol} / \mathrm{L} . \mathrm{d})$ & 10,1 & 7,6 & 4,8 & \multicolumn{2}{|c|}{ Não validado } \\
\hline Modelo & \multicolumn{5}{|c|}{$3,21+0,76 x_{1}-0,57 x_{1}^{2}+1,21 x_{2}-0,80 x_{2}^{2}+0,76 x_{1} x_{2}\left(R^{2}=0,81\right)$} \\
\hline Ac. Succínico & 4,5 & 6,0 & $26,58 \%$ & \multicolumn{2}{|c|}{ Não validado } \\
\hline Modelo & \multicolumn{5}{|c|}{$26,50-0,89 \mathrm{x}_{1}-2,74 \mathrm{x}_{1}^{2}-2,01 \mathrm{x}_{2}^{2}(\mathrm{R} 2=0,97)$} \\
\hline MS removida & 5,6 & 6,1 & $4,0 \mathrm{~g} / \mathrm{L}$ & $4,0^{*}$ & $100 \%$ \\
\hline Modelo & \multicolumn{5}{|c|}{$3,95+0,39 \mathrm{x}_{1}-0,92 \mathrm{x}_{1}^{2}+0,21 \mathrm{x}_{2}-1,14 \mathrm{x}_{2}^{2}\left(\mathrm{R}^{2}=0,99\right)$} \\
\hline
\end{tabular}

* Ajuste de acordo com as condições de R9 e R10

$\mathrm{x}_{1}=$ valor codificado de concentração de substrato; $\mathrm{x}_{2}=$ valor codificado de $\mathrm{pH}$ 
De acordo com o mapeamento da conversão do BCA em açúcares, ácidos orgânicos e hidrogênio e identificação das bactérias dos reatores de produção de hidrogênio (R9 e Rotm), pode-se observar que espécies de Clostridium foram as principais bactérias celulolíticas atuantes na hidrólise do BCA. Além disso, Clostridium foram os fermentadores de hexoses e pentoses em ácido acético, butírico, valérico e propiônico e hidrogênio, ressaltando a sua dominância e versatilidade de Clostridium em processos fermentativos de produção de hidrogênio. No entanto, foi notável a identificação de bactérias semelhantes a de L. paracasei e E. hermannii, provavelmente relacionadas com a fermentação de açúcares em ácido acético, Bacteroides sp. na formação dos ácidos butírico e succínico e E. aerogenes na formação dos ácidos acético, butírico e propiônico (Figura 5.35). 
Celulolíticas

C. cellobioparum

C. cellulolyticum

C. sartagoforme

Paenibacillus sp.

Degradadoras de celobiose

B. xylanolyticus

C. cellulolyticum

C. sartagoforme

E. aerogenes

E. hermannii

L. paracasei

Produtoras de ácido acético

B. coagulas

Bacteroides sp.

C. cellobioparum

C. cellulolyticum

C. sartagoforme

E. aerogenes

E. hermannii

L. paracasei

Paenibacillus sp.

Produtoras de

ácido butírico

B. coagulas

C. bifermentans

C. sartagoforme

E. aerogenes

Produtoras de

ácido valérico

C. bifermentans

Produtoras de

ácido succínico

Bacteroides sp.

Produtoras de

ácido propiônico

C. bifermentans

Acetogênicas

Clostridium sp.
BCA

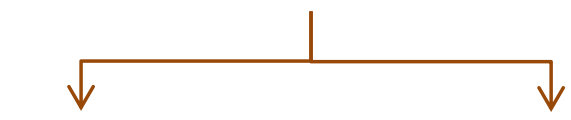

Celulose

Hemicelulose<smiles>[C]1C=C1</smiles>

Celobiose

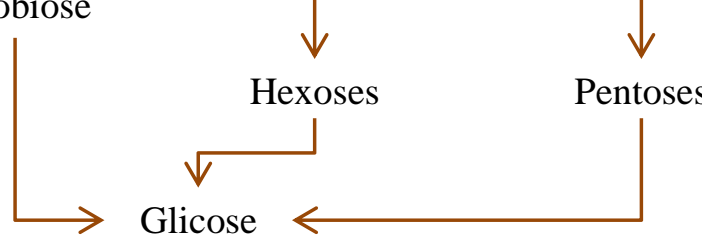

Piruvato

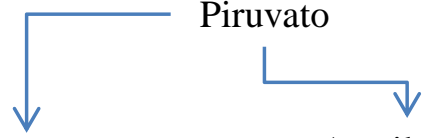

Ácido lático<smiles>C1C2CC12</smiles>

Ácido propiônico<smiles>C1CC1</smiles>

Ácido valérico

Butiril CoA<smiles>C[C@@H]1CC[C@@H]1C(C)(C)C</smiles>

Butiril P<smiles>C1C2CC1C2</smiles>

Ácido butírico

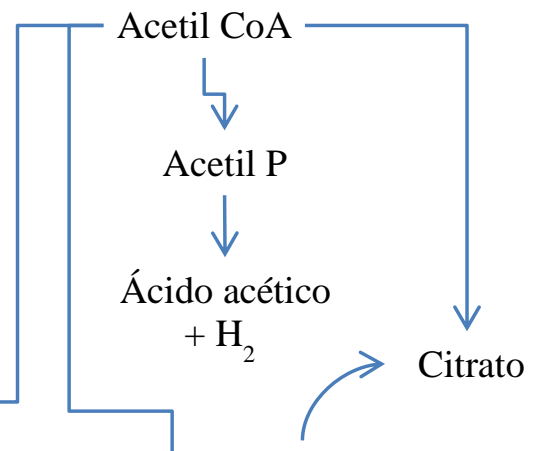

Oxaloacetato

Isocitrato

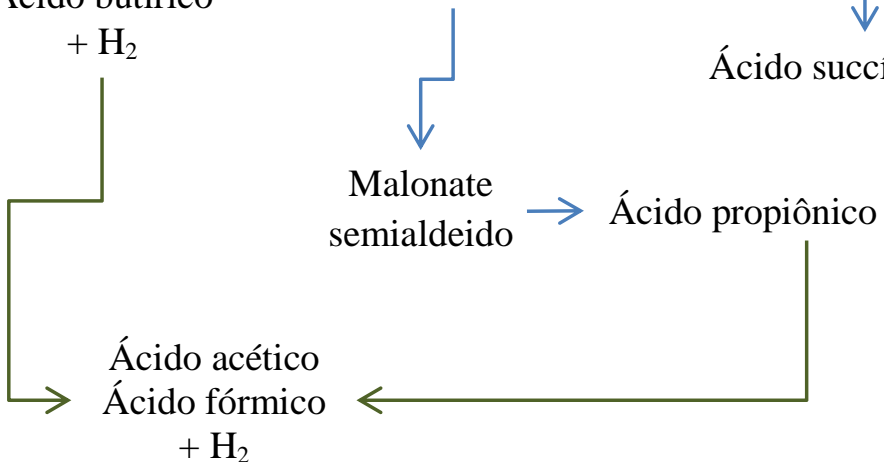

Figura 5.35: Rotas de conversão do BCA em açúcares, ácidos orgânicos e hidrogênio. 


\section{CONSIDERAÇÕES FINAIS}

Hipótese 1: As bactérias autóctones do bagaço de cana-de-açúcar podem contribuir com consórcio fermentativo e favorecer a hidrólise e fermentação do bagaço.

Hipótese aceita: Por meio das análises biomoleculares das comunidades bacterianas autóctones do bagaço cana-de-açúcar e dos reatores de produção de hidrogênio, verificou-se que há bactérias celulolíticas e/ou fermentativas aderidas no BCA que, juntamente com as condições diferenciadas de concentração de substrato e pH impostas aos reatores, contribuíram e alteraram as populações de bactérias dos reatores fermentativos

- O consórcio formado por bactérias oriundas, tanto do inóculo, quanto do BCA autoclavado formaram uma comunidade que foi capaz de converter o substrato lignocelulósico em hidrogênio.

Hipótese 2: O pré-tratamento aplicado no bagaço de cana-de-açúcar pode modificar as populações de bactérias hidrolíticas/fermentativas, bem como favorecer a produção de hidrogênio.

Hipótese aceita: a melhor produção de hidrogênio e também velocidade de produção de hidrogênio foram obtidas com o BCA pré-tratatado em autoclave quando comparado com hidrotérmico e autoclave mais hidrotérmico, e mais a condição in natura como substrato.

- De acordo com o perfil de bandas do gel de DGGE, pode-se concluir que houve mudança nas comunidades bacterianas utilizando BCA in natura ou pré-tratado como substrato e, ainda, houve mudança nas comunidades bacterianas de diferentes prétratamentos aplicados no BCA.

- O tratamento do BCA em autoclave, por ser menos severo do que o hidrotérmico, provavelmente, pode ter favorecido a sobrevivência de bactérias formadoras de endósporos autóctones do BCA, principalmente celulolíticas, que, juntamente com o inóculo fermentativo, atuaram na hidrólise do BCA.

Hipótese 3: Fatores como concentração de substrato e pH podem favorecer ou inibir as populações de bactérias hidrolíticas/fermentativas e, consequentemente, a bioconversão do bagaço de cana-de-açúcar em hidrogênio e ácidos orgânicos. 
Hipótese aceita: de acordo com análises de delineamento fatorial por composto central, os fatores concentração de substrato e pH e também a interação entre eles exerceram efeitos significativos sobre as respostas produção e velocidade de produção de hidrogênio.

- O maior valor obtido para produção de hidrogênio foi de $24,06 \mathrm{mmol} \mathrm{H}_{2} / \mathrm{L}$, com 8,0 g/L de substrato e $\mathrm{pH}$ 7,0. O menor valor obtido para produção de hidrogênio foi de $0,33 \mathrm{mmol} / \mathrm{L}$ com $5,0 \mathrm{~g} / \mathrm{L}$ de substrato e $\mathrm{pH}$ 4,6.

- De acordo com os açúcares quantificados nos reatores em batelada, tanto a celulose, como a hemicelulose do BCA foram hidrolisadas pela biomassa do inóculo fermentativo e bactérias autóctones do BCA.

- As produções finais de ácidos butírico e succínico também foram afetadas pelas variações de concentração de substrato e $\mathrm{pH}$.

- As bactérias com maior abundância relativa identificadas no inóculo ( $C$. bifermentans, $62,69 \%$ e Bacillus coagulans, 31,67\%) e/ou aderidas no BCA ( $C$. bifermentans, 31,91\% e C. cellobioparum, 32,29\%) não foram favorecidas sob as condições impostas ao R9 e Rotm, uma vez que as abundâncias relativas das bactérias identificadas nas amostras dos reatores foram completamente diferentes. 


\section{CONCLUSÕES}

- Dentre os pré-tratamentos testados (autoclave, hidrotérmico, hidrotérmico seguido de térmico e também em relação à condição in natura) obteve-se maior produção de hidrogênio nas condições do pré-tratamento térmico em autoclave $\left(121^{\circ} \mathrm{C}, 1 \mathrm{~atm}\right.$ por 15 minutos);

- As populações de bactérias hidrolíticas/fermentativas e produção de metabólitos foram alteradas em função das condições impostas; ou seja, concentração de BCA, pH em reatores em batelada com BCA autoclavado como substrato;

- O substrato utilizado, BCA autoclavado, contribuiu com bactérias, principalmente celulolíticas, para hidrólise e fermentação do BCA em hidrogênio e ácidos orgânicos;

- A análise de açúcares solúveis pode ser utilizada como monitoramento de reatores em batelada e como indicativo da hidrólise de celulose e/ou hemicelulose de substratos lignocelulósicos;

- O consórcio de bactérias oriundas, tanto do inóculo fermentativo, quanto do BCA autoclavado continha populações em baixa abundância relativa que converteram o substrato lignocelulósico em hidrogênio e ácidos orgânicos com variações de concentração de BCA de 0,8 até 9,2 g/L e pH de 4,6 até 7,4. 


\section{RECOMENDAÇÕES}

- Utilizar as condições otimizadas $(7,0 \mathrm{~g} \mathrm{BCA} / \mathrm{L} \mathrm{e} \mathrm{pH} 7,2)$ nos futuros trabalhos com bagaço de cana-de-açúcar como substrato;

- Utilizar as condições otimizadas $(7,0 \mathrm{~g}$ BCA/L e pH 7,2) em reator contínuo de produção de hidrogênio a partir do bagaço de cana-de-açúcar como substrato;

- Isolar e concentrar as bactérias do BCA autoclavado a fim de utilizá-las como inóculo hidrolítico/fermentativo em reatores de produção de biocombustíveis com substratos celulolíticos. 


\section{REFERÊNCIAS}

Ahmad, F., 2017. Produção de metano em resposta ao pré-tratamento hidrotérmico comácido sulfúrico e peróxido de hidrogênio do bagaço de cana de açúcar. Tese (Doutorado). Escola de Engenharia de São Carlos, Universidade de São Paulo.

Alvira, P., Tomás-Pejó, E., Ballesteros, M., Negro, M.J., 2010. Pretreatment technologies for an efficient bioethanol production process based on enzymatic hydrolysis: A review. Bioresour. Technol. 101, 4851-4861. doi:10.1016/j.biortech.2009.11.093

Antonopoulou, G., Gavala, H.N., Skiadas, I. V., Angelopoulos, K., Lyberatos, G., 2008. Biofuels generation from sweet sorghum: Fermentative hydrogen production and anaerobic digestion of the remaining biomass. Bioresour. Technol. 99, 110-119. doi:10.1016/j.biortech.2006.11.048

APHA, 2005. Standart methods for the examination of water and wastewater, 21st ed. American Publisher Health Association, Washington, DC, USA.

Aquino, S.F., Silva, S.Q., Chernicharo, C.A., 2006. Pratical aspects of the chemical oxygen demand (COD) test applied to the analysis of anaerobic effluents. Eng. Sanitária e Mabiental II, 295-304.

Araujo, P.W., Brereton, R.G., 1996. Experimental design II. Optimization. Trends Anal. Chem. 15, 63-70.

Arreola-Vargas, J., Celis, L.B., Buitrón, G., Razo-Flores, E., Alatriste-Mondragón, F., 2013. Hydrogen production from acid and enzymatic oat straw hydrolysates in an anaerobic sequencing batch reactor: Performance and microbial population analysis. Int. J. Hydrogen Energy 38, 13884-13894. doi:10.1016/j.ijhydene.2013.08.065

Béguin, P., Lemaire, M., 1996. The cellulosome: an exocellular, multiprotein complex specialized in cellulose degradation. Crit. Rev. Biochem. Mol. Biol. 31, 201-236. doi:10.3109/10409239609106584

Bezerra, M.A., Santelli, R.E., Oliveira, E.P., Villar, L.S., Escaleira, L.A., 2008. Response surface methodology (RSM) as a tool for optimization in analytical chemistry. Talanta 76, 965-977. doi:10.1016/j.talanta.2008.05.019

Binod, P., Janu, K.U., Sindhu, R., 2011. Hydrolysis of Lignocellulosic Biomass for Bioethanol Production, in: Press, A. (Ed.), Biofuels Alternative Feedstocks and Conversion Process. Elsevier Inc., Burlington, pp. 229-250. doi:10.1016/B978-0-12385099-7.00010-3

Black, J.G., Black, L.J., 2015. Microbiology: Principles and Explorations, 9th ed. Wiley Global Education.

Botta, L.S., Ratti, R.P., Sakamoto, I.K., Ramos, L.R., Silva, E.L., Varesche, M.B.A., 2016. Bioconversion of waste office paper to hydrogen using pretreated rumen fluid inoculum. Bioprocess Biosyst. Eng. doi:10.1007/s00449-016-1663-0

Brenner, D.J., Davis, B.R., Steigerwalt, A.G., Riddle, C.F., McWhorter, A.C., Allen, 
S.D., Farmer, J.J., Saitoh, Y., Fanning, G.R., 1982. Atypical biogroups of Escherichia coli found in clinical specimens and description of Escherichia hermannii sp. nov. J. Clin. Microbiol. 15, 703-713.

Bundhoo, M.A.Z., Mohee, R., 2016. Inhibition of dark fermentative bio-hydrogen production: A review. Int. J. Hydrogen Energy 41, 6713-6733. doi:10.1016/j.ijhydene.2016.03.057

Candido, R.G., Godoy, G.G., Gonçalves, A.R., 2012. Study of sugarcane bagasse pretreatment with sulfuric acid as a step of cellulose obtaining. Eng. Technol. 61, $101-105$.

Canilha, L., Chandel, A.K., Suzane Dos Santos Milessi, T., Antunes, F.A.F., Luiz Da Costa Freitas, W., Das Graças Almeida Felipe, M., Da Silva, S.S., 2012. Bioconversion of sugarcane biomass into ethanol: An overview about composition, pretreatment methods, detoxification of hydrolysates, enzymatic saccharification, and ethanol fermentation. J. Biomed. Biotechnol. 2012. doi:10.1155/2012/989572

Cardona, C.A., Quintero, J.A., Paz, I.C., 2010. Production of bioethanol from sugarcane bagasse: Status and perspectives. Bioresour. Technol. 101, 4754-4766. doi:10.1016/j.biortech.2009.10.097

Cater, M., Fanedl, L., Malovrh, S., Marinsek Logar, R., 2015. Biogas production from brewery spent grain enhanced by bioaugmentation with hydrolytic anaerobic bacteria. Bioresour. Technol. 186, 261-269. doi:10.1016/j.biortech.2015.03.029

Cavedon, K., Canale-Parola, E., 1992. Physiological interactions between a mesophilic cellulolytic Clostridium and a non-cellulolitic bacterium. FEMS Microbiol. Ecol. 86, 237-245.

Chaganti, S.R., Kim, D.H., Lalman, J.A., Shewa, W.A., 2012. Statistical optimization of factors affecting biohydrogen production from xylose fermentation using inhibited mixed anaerobic cultures. Int. J. Hydrogen Energy 37, 11710-11718. doi:10.1016/j.ijhydene.2012.05.036

Chen, Y., Nielsen, J., 2016. Biobased organic acids production by metabolically engineered microorganisms. Curr. Opin. Biotechnol. 37, 165-172. doi:10.1016/j.copbio.2015.11.004

Cherubini, F., 2010. The biorefinery concept: Using biomass instead of oil for producing energy and chemicals. Energy Convers. Manag. 51, 1412-1421. doi:10.1016/j.enconman.2010.01.015

Chu, Y., Wei, Y., Yuan, X., Shi, X., 2011. Bioconversion of wheat stalk to hydrogen by dark fermentation: Effect of different mixed microflora on hydrogen yield and cellulose solubilisation. Bioresour. Technol. 102, 3805-3809. doi:10.1016/j.biortech.2010.11.092

Cisneros-Pérez, C., Carrillo-Reyes, J., Celis, L.B., Alatriste-Mondragón, F., Etchebehere, C., Razo-Flores, E., 2015. Inoculum pretreatment promotes differences in hydrogen 
production performance in EGSB reactors. Int. J. Hydrogen Energy 40, 6329-6339. doi:10.1016/j.ijhydene.2015.03.048

Cleveland, J., Montville, T.J., Nes, I.F., Chikindas, M.L., 2001. Bacteriocins: Safe, natural antimicrobials for food preservation. Int. J. Food Microbiol. 71, 1-20. doi:10.1016/S0168-1605(01)00560-8

Cybulska, I., Lei, H., Julson, J., 2010. Hydrothermal pretreatment and enzymatic hydrolysis of prairie cord grass. Energy and Fuels 24, 718-727. doi:10.1021/ef9009179

Datar, R., Huang, J., Maness, P.C., Mohagheghi, A., Czernik, S., Chornet, E., 2007. Hydrogen production from the fermentation of corn stover biomass pretreated with a steam-explosion process. Int. J. Hydrogen Energy 32, 932-939. doi:10.1016/j.ijhydene.2006.09.027

Deng, W., Wang, Y., Yan, N., 2016. Production of organic acids from biomass resources. Curr. Opin. Green Sustain. Chem. 2, 54-58. doi:10.1016/j.cogsc.2016.10.002

Desvaux, M., 2005. Clostridium cellulolyticum: Model organism of mesophilic cellulolytic clostridia. FEMS Microbiol. Rev. 29, 741-764. doi:10.1016/j.femsre.2004.11.003

Desvaux, M., Guedon, E., Petitdemange, H., 2000. Cellulose catabolism by Clostridium cellulolyticum growing in batch culture on defined medium. Appl. Environ. Microbiol. 66, 2461-2470. doi:10.1128/AEM.66.6.2461-2470.2000

Deublein, D., Steinhauser, A., 2010. Biogas from Waste and Renewable Resources: An Introduction, Second Edition. doi:10.1002/9783527632794

Dionisi, D., Silva, I.M.O., 2016. Production of ethanol, organic acids and hydrogen: an opportunity for mixed culture biotechnology? Rev. Environ. Sci. Biotechnol. 15, 213-242. doi:10.1007/s11157-016-9393-y

DSM, 1991. - Scientific Services of Culture Collections - Coloração de Gram. Curso Minist. na Fundação Trop. Pesqui. e Tecnol. “André Tosello”, Campinas.

Du, R., Yan, J., Li, S., Zhang, L., Zhang, S., Li, J., Zhao, G., Qi, P., 2015. Cellulosic ethanol production by natural bacterial consortia is enhanced by Pseudoxanthomonas taiwanensis. Biotechnol. Biofuels 8, 1-10. doi:10.1186/s13068-014-0186-7

Fan, Y.T., Zhang, Y.H., Zhang, S.F., Hou, H.W., Ren, B.Z., 2006. Efficient conversion of wheat straw wastes into biohydrogen gas by cow dung compost. Bioresour. Technol. 97, 500-505. doi:10.1016/j.biortech.2005.02.049

Fangkum, A., Reungsang, A., 2011. Biohydrogen production from sugarcane bagasse hydrolysate by elephant dung: Effects of initial $\mathrm{pH}$ and substrate concentration. Int. J. Hydrogen Energy 36, 8687-8696. doi:10.1016/j.ijhydene.2010.05.119

Peng, F., Peng, P., Xu, F., Sun, R.C., 2012. Fractional purification and bioconversion of 
hemicelluloses. Biotechnol. Adv. 30, 879-903.doi:10.1016/j.biotechadv.2012.01.018

Gadow, S.I., Li, Y.Y., Liu, Y., 2012. Effect of temperature on continuous hydrogen production of cellulose. Int. J. Hydrogen Energy 37, 15465-15472. doi:10.1016/j.ijhydene.2012.04.128

Galbe, M., Zacchi, G., 2012. Pretreatment: The key to efficient utilization of lignocellulosic materials. Biomass and Bioenergy 46, 70-78. doi:10.1016/j.biombioe.2012.03.026

Gomez-Romero, J., Gonzalez-Garcia, A., Chairez, I., Torres, L., García-Peña, E.I., 2014. Selective adaptation of an anaerobic microbial community: Biohydrogen production by co-digestion of cheese whey and vegetables fruit waste. Int. J. Hydrogen Energy 39, 12541-12550. doi:10.1016/j.ijhydene.2014.06.050

Griffiths, R.I., Whiteley, A.S., O’Donnel, A.G., 2000. Rapid method for coextraction of DNA from natural environments for analysis of ribossomal DNA and rRNA based microbial community composition. Appl. Environ. Microbiol. 66, 5488-5491.

Grimont, P.A.D., Grimont, F., 2005. Genus Enterobacter. Bergey’s Man. Sist. Bacteriol. Vol. Two 2.

Guedon, E., Desvaux, M., Payot, S., Petitdemange, H., Gram, B., Henri, U., 1999a. Growth inhibition of Clostridium cellulolyticum by an inefficiently regulated carbon flow 1831-1838. doi:10.1099/13500872-145-8-1831

Guedon, E., Payot, S., Desvaux, M., Petitdemange, H., 2000. Relationships between cellobiose catabolism, enzyme levels, and metabolic intermediates in Clostridium cellulolyticum grown in a synthetic medium. Biotechnol. Bioeng. 67, 327-335. doi:10.1002/(SICI)1097-0290(20000205)67:3<327::AID-BIT9>3.0.CO;2-U

Guedon, E., Payot, S., Desvaux, M., Petitdemange, H., 1999b. Carbon and electron flow in Clostridium cellulolyticum grown in chemostat culture on synthetic medium. J. Bacteriol. 181, 3262-3269.

Guo, X.M., Trably, E., Latrille, E., Carrre, H., Steyer, J.P., 2010. Hydrogen production from agricultural waste by dark fermentation: A review. Int. J. Hydrogen Energy 35, 10660-10673. doi:10.1016/j.ijhydene.2010.03.008

Gupta, M., Velayutham, P., Elbeshbishy, E., El, M.H., Levin, D.B., Nakhla, G., 2014a. Co-fermentation of glucose, starch, and cellulose for mesophilic biohydrogen production. Int. J. Hydrogen Energy 39, 20958-20967. doi:10.1016/j.ijhydene.2014.10.079

Gupta, M., Velayutham, P., Elbeshbishy, E., Hafez, H., Khafipour, E., Derakhshani, H., El Naggar, M.H., Levin, D.B., Nakhla, G., 2014b. Co-fermentation of glucose, starch, and cellulose for mesophilic biohydrogen production. Int. J. Hydrogen Energy 39, 20958-20967. doi:10.1016/j.ijhydene.2014.10.079

Hallenbeck, P.C., 2009. Fermentative hydrogen production: Principles, progress, and prognosis. Int. J. Hydrogen Energy 34, 7379-7389. 
doi:10.1016/j.ijhydene.2008.12.080

Hallenbeck, P.C., Benemann, J.R., 2002. Biological hydrogen production; Fundamentals and limiting processes. Int. J. Hydrogen Energy 27, 1185-1193. doi:10.1016/S03603199(02)00131-3

Hallenbeck, P.C., Ghosh, D., 2009. Advances in fermentative biohydrogen production: the way forward? Trends Biotechnol. 27, 287-297. doi:10.1016/j.tibtech.2009.02.004

Haruta, S., Cui, Z., Huang, Z., Li, M., Ishii, M., Igarashi, Y., 2002. Construction of a stable microbial community with high cellulose-degradation ability. Appl. Microbiol. Biotechnol. 59, 529-534. doi:10.1007/s00253-002-1026-4

Ho, K.L., Lee, D.J., Su, A., Chang, J.S., 2012. Biohydrogen from lignocellulosic feedstock via one-step process. Int. J. Hydrogen Energy 37, 15569-15574. doi:10.1016/j.ijhydene.2012.01.137

Infantes, D., González Del Campo, A., Villaseñor, J., Fernández, F.J., 2011. Influence of $\mathrm{pH}$, temperature and volatile fatty acids on hydrogen production by acidogenic fermentation. Int. J. Hydrogen Energy 36, 15595-15601. doi:10.1016/j.ijhydene.2011.09.061

Jo, J.H., Lee, D.S., Park, D., Choe, W.S., Park, J.M., 2008a. Optimization of key process variables for enhanced hydrogen production by Enterobacter aerogenes using statistical methods. Bioresour. Technol. 99, 2061-2066. doi:10.1016/j.biortech.2007.04.027

Jo, J.H., Lee, D.S., Park, D., Park, J.M., 2008b. Statistical optimization of key process variables for enhanced hydrogen production by newly isolated Clostridium tyrobutyricum JM1. Int. J. Hydrogen Energy 33, 5176-5183. doi:10.1016/j.ijhydene.2008.05.012

Jo, J.H., Lee, D.S., Park, J.M., 2008c. The effects of pH on carbon material and energy balances in hydrogen-producing Clostridium tyrobutyricum JM1. Bioresour. Technol. 99, 8485-8491. doi:10.1016/j.biortech.2008.03.060

Kabel, M.A., Bos, G., Zeevalking, J., Voragen, A.G.J., Schols, H.A., 2007. Effect of pretreatment severity on xylan solubility and enzymatic breakdown of the remaining cellulose from wheat straw. Bioresour. Technol. 98, 2034-2042. doi:10.1016/j.biortech.2006.08.006

Kanso, S., Dasri, K., Tingthong, S., Watanapokasin, R.Y., 2011. Diversity of cultivable hydrogen-producing bacteria isolated from agricultural soils, waste water sludge and cow dung. Int. J. Hydrogen Energy 36, 8735-8742. doi:10.1016/j.ijhydene.2010.07.010

Kato, S., Haruta, S., Cui, Z.J., Ishii, M., Igarashi, Y., 2008. Network relationships of bacteria in a stable mixed culture. Microb. Ecol. 56, 403-411. doi:10.1007/s00248007-9357-4 
Khan, M.A., Ngo, H.H., Guo, W.S., Liu, Y., Nghiem, L.D., Hai, F.I., Deng, L.J., Wang, J., Wu, Y., 2016. Optimization of process parameters for production of volatile fatty acid, biohydrogen and methane from anaerobic digestion. Bioresour. Technol. 219, 738-748. doi:10.1016/j.biortech.2016.08.073

Kiernicka, J., Seignez, C., Peringer, P., 1999. Escherichia hermanii--a new bacterial strain for chlorobenzene degradation. Lett. Appl. Microbiol. 28, 27-30. doi:10.1046/j.1365-2672.1999.00475.x

Kim, J., Park, C., Kim, T.-H., Lee, M., Kim, S., Kim, S.-W., Lee, J., 2003. Effects of Various Pretreatments for Enhanced Anaerobic Digestion with Waste Activated Sludge. J. Biosci. Bioeng. 95, 271-275. doi:10.1263/jbb.95.271

Kim, S., Holtzapple, M.T., 2005. Lime pretreatment and enzymatic hydrolysis of corn stover. Bioresour. Technol. 96, 1994-2006. doi:10.1016/j.biortech.2005.01.014

Kornochalert, N., Kantachote, D., Chairprapat, S., Techkarnjanaruk, S., 2014. Bioaugmentation of latex rubber sheet wastewater treatment with stimulated indigenous purple nonsulfur bacteria by fermented pineapple extract. Electron. J. Biotechnol. 174-182.

Kotay, S.M., Das, D., 2007. Microbial hydrogen production with Bacillus coagulans IITBT S1 isolated from anaerobic sewage sludge. Bioresour. Technol. 98, 1183-1190. doi:10.1016/j.biortech.2006.05.009

Kreuger, E., Sipos, B., Zacchi, G., Svensson, S.E., Björnsson, L., 2011. Bioconversion of industrial hemp to ethanol and methane: The benefits of steam pretreatment and coproduction. Bioresour. Technol. 102, 3457-3465. doi:10.1016/j.biortech.2010.10.126

Kumar, R., Singh, S., Singh, O. V., 2008. Bioconversion of lignocellulosic biomass: Biochemical and molecular perspectives. J. Ind. Microbiol. Biotechnol. 35, 377-391. doi:10.1007/s10295-008-0327-8

Lai, Z., Zhu, M., Yang, X., Wang, J., Li, S., 2014. Optimization of key factors affecting hydrogen production from sugarcane bagasse by a thermophilic anaerobic pure culture. Biotechnol. Biofuels 7, 1-11. doi:10.1186/s13068-014-0119-5

Lakshmidevi, R., Muthukumar, K., 2010. Enzymatic saccharification and fermentation of paper and pulp industry effluent for biohydrogen production. Int. J. Hydrogen Energy 35, 3389-3400. doi:10.1016/j.ijhydene.2009.12.165

Laser, M., Schulman, D., Allen, S.G., Lichwa, J., Antal, M.J., Lynd, L.R., 2002. A comparison of liquid hot water and steam pretreatments of sugar cane bagasse for bioconversion to ethanol 81, 33-44.

Lay, J.J., 2001. Biohydrogen generation by mesophilic anaerobic fermentation of microcrystalline cellulose. Biotechnol. Bioeng. 74, 280-287. doi:10.1002/bit.1118

Lei, H., Cybulska, I., Julson, J., 2013. Hydrothermal Pretreatment of Lignocellulosic Biomass and Kinetics 2013, 250-259. doi:10.1533/9781845699611.1.3 
Leschine, S.B., 1995. Cellulose degradation in anaerobic environments. Annu. Rev. Microbiol. 49, 399-426. doi:10.1146/annurev.micro.49.1.399

Levin, D.B., Carere, C.R., Cicek, N., Sparling, R., 2009. Challenges for biohydrogen production via direct lignocellulose fermentation. Int. J. Hydrogen Energy 34, 73907403. doi:10.1016/j.ijhydene.2009.05.091

Li, C., Fang, H.H.P., 2007. Fermentative Hydrogen Production From Wastewater and Solid Wastes by Mixed Cultures. Crit. Rev. Environ. Sci. Technol. 37, 1-39. doi:10.1080/10643380600729071

Li, Y.C., Wu, S.Y., Chu, C.Y., Huang, H.C., 2011. Hydrogen production from mushroom farm waste with a two-step acid hydrolysis process. Int. J. Hydrogen Energy 36, 14245-14251. doi:10.1016/j.ijhydene.2011.06.102

Lin, C., Chang, C., Hung, C., 2008. Fermentative hydrogen production from starch using natural mixed cultures. Int. J. Hydrogen Energy 33, 2445-2453. doi:10.1016/j.ijhydene.2008.02.069

Lin, C.Y., Hung, W.C., 2008. Enhancement of fermentative hydrogen/ethanol production from cellulose using mixed anaerobic cultures. Int. J. Hydrogen Energy 33, 36603667. doi:10.1016/j.ijhydene.2008.04.036

Liu, G.G.Z., Shen, J.J.Q., 2004. Effects of culture and medium conditions on hydrogen production from starch using anaerobic bacteria. J. Biosci. Bioeng. 98, 251-256. doi:10.1016/S1389-1723(04)00277-4

Lo, Y., Bai, M., Chen, W., Chang, J., 2008. Cellulosic hydrogen production with a sequencing bacterial hydrolysis and dark fermentation strategy. Bioresour. Technol. 99, 8299-8303.

Lo, Y.C., Saratale, G.D., Chen, W.M., Bai, M. Der, Chang, J.S., 2009a. Isolation of cellulose-hydrolytic bacteria and applications of the cellulolytic enzymes for cellulosic biohydrogen production. Enzyme Microb. Technol. 44, 417-425. doi:10.1016/j.enzmictec.2009.03.002

Lo, Y.C., Su, Y.C., Chen, C.Y., Chen, W.M., Lee, K.S., Chang, J.S., 2009b. Biohydrogen production from cellulosic hydrolysate produced via temperature-shift-enhanced bacterial cellulose hydrolysis. Bioresour. Technol. 100, 5802-5807. doi:10.1016/j.biortech.2009.06.066

Lynd, L.R., 1996. Overview and evaluation of fuel ethanol from cellulosic biomass: Technology, Economics, the Environment, and Policy. Annu. Rev. Energy Environ. 21, 403-465. doi:10.1146/annurev.energy.21.1.403

Ma, X.J., Cao, S.L., Lin, L., Luo, X.L., Hu, H.C., Chen, L.H., Huang, L.L., 2013. Hydrothermal pretreatment of bamboo and cellulose degradation. Bioresour. Technol. 148, 408-413. doi:10.1016/j.biortech.2013.09.021

Matsumoto, M., Nishimura, Y., 2007. Hydrogen production by fermentation using acetic acid and lactic acid. J. Biosci. Bioeng. 103, 236-41. doi:10.1263/jbb.103.236 
Miao, J., Guo, H., Ou, Y., Liu, G., Fang, X., Liao, Z., Ke, C., Chen, Y., Zhao, L., Cao, Y., 2014. Purification and characterization of bacteriocin F1, a novel bacteriocin produced by Lactobacillus paracasei subsp. tolerans FX-6 from Tibetan kefir, a traditional fermented milk from Tibet, China. Food Control 42, 48-53. doi:10.1016/j.foodcont.2014.01.041

Montgomery, D.C., 2012. Design and Analysis of Experiments, 8th ed, Design. Tempe, Arizona. doi:10.1198/tech.2006.s372

Morrell-Falvey, J.L., Elkins, J.G., Wang, Z.-W., 2015. Determination of the cellulase activity distribution in Clostridium thermocellum and Caldicellulosiruptor obsidiansis cultures using fluorescent substrate. J. Environ. Sci. 34, 1-7. doi:10.1016/j.jes.2015.03.009

Nakashimada, Y., Rachman, M.A., Kakizono, T., Nishio, N., 2002. Hydrogen production of Enterobacter aerogenes altered by extracellular and intracellular redox states. Int. J. Hydrogen Energy 27, 1399-1405. doi:10.1016/S0360-3199(02)00128-3

Noike, T., Takabatake, H., Mizuno, O., Ohba, M., 2002. Inhibition of hydrogen fermentation of organic wastes by lactic acid bacteria. Int. J. Hydrogen Energy 27, 1367-1371. doi:10.1016/S0360-3199(02)00120-9

Nubel, U., Engelen, B., Felske, A., Snaidr, J., Wieshuber, A., Amann, R.I., Ludwig, W., Backhaus, H., 1996. Sequence heterogeneities of genes encoding 16lthinspaceS rRNAs in Paenibacillus polymyxa detected by temperature gradient gel electrophoresis. J Bacteriol 178, 5636-5643.

Nzila, A., 2017. Mini review: Update on bioaugmentation in anaerobic processes for biogas production. Anaerobe 46, 3-12. doi:10.1016/j.anaerobe.2016.11.007

Olsen, S.N., Lumby, E., McFarland, K., Borch, K., Westh, P., 2011. Kinetics of enzymatic high-solid hydrolysis of lignocellulosic biomass studied by calorimetry. Appl. Biochem. Biotechnol. 163, 626-635. doi:10.1007/s12010-010-9068-z

Ozbayram, E.G., Kleinsteuber, S., Nikolausz, M., Ince, B., Ince, O., 2016. Effect of bioaugmentation by cellulolytic bacteria enriched from sheep rumen on methane production from wheat straw. Anaerobe 1-9. doi:10.1016/j.anaerobe.2017.03.013

Ozkan, L., Erguder, T.H., Demirer, G.N., 2011. Effects of pretreatment methods on solubilization of beet-pulp and bio-hydrogen production yield. Int. J. Hydrogen Energy 36, 382-389. doi:10.1016/j.ijhydene.2010.10.006

Pan, C., Fan, Y., Hou, H., 2008. Fermentative production of hydrogen from wheat Bran by mixed anaerobic cultures. Ind. Eng. Chem. Res. 47, 5812-5818. doi:10.1021/ie701789c

Pan, C.M., Fan, Y.T., Xing, Y., Hou, H.W., Zhang, M.L., 2008. Statistical optimization of process parameters on biohydrogen production from glucose by Clostridium sp. Fanp2. Bioresour. Technol. 99, 3146-3154. doi:10.1016/j.biortech.2007.05.055

Pandey, A., Soccol, C.R., Nigam, P., Soccol, V.T., 2000. Biotechnological potential of 
agro-industrial residues . I : sugarcane bagasse 74 .

Pattra, S., Sangyoka, S., Boonmee, M., Reungsang, A., 2008. Bio-hydrogen production from the fermentation of sugarcane bagasse hydrolysate by Clostridium butyricum. Int. J. Hydrogen Energy 33, 5256-5265. doi:10.1016/j.ijhydene.2008.05.008

Percival Zhang, Y.H., Himmel, M.E., Mielenz, J.R., 2006. Outlook for cellulase improvement: Screening and selection strategies. Biotechnol. Adv. 24, 452-481. doi:10.1016/j.biotechadv.2006.03.003

Pérez, J., Muñoz-Dorado, J., De La Rubia, T., Martínez, J., 2002. Biodegradation and biological treatments of cellulose, hemicellulose and lignin: An overview. Int. Microbiol. 5, 53-63. doi:10.1007/s10123-002-0062-3

Perna, V., Castelló, E., Wenzel, J., Zampol, C., Fontes Lima, D.M., Borzacconi, L., Varesche, M.B., Zaiat, M., Etchebehere, C., 2013. Hydrogen production in an upflow anaerobic packed bed reactor used to treat cheese whey. Int. J. Hydrogen Energy 38, 54-62. doi:10.1016/j.ijhydene.2012.10.022

Petitdemange, E., Tchunden, T., Vallés, S., Pirson, H., Raval, G., Gay, R., 1992. Effect of carbon sources on cellulase production by Clostridium cellulolyticum. Biomass and Bioenergy 3, 393-402.

Rabelo, C.A.B.S., Botta, L.S., Varesche, M.B.A., 2014. Avaliação de consórcio microbiano visando à produção de $\mathrm{H} 2$ a partir de celulose (Evaluation of microbial consortium aiming at the $\mathrm{H} 2$ production from cellulose), in: Proc. XI DAAL - Latin American Workshop and Symposium on Anaerobic Digestion. Havana, Cuba.

Rabelo, C.A.B.S., Soares, L.A., Varesche, M.B.A., 2017. Comparison and Evaluation of Hydrogen and Methane Productions from Hydrothermal Pretreated Sugarcane Bagasse by Two Microbial Consortium. Austin Clin. Microbiol. 2, 1-6.

Rabelo, S.C., Carrere, H., Maciel Filho, R., Costa, a. C., 2011. Production of bioethanol, methane and heat from sugarcane bagasse in a biorefinery concept. Bioresour. Technol. 102, 7887-7895. doi:10.1016/j.biortech.2011.05.081

Rainey, F.A., 2009. Class Clostridia, in: Brenner, D., Krieg, N., Staley, J. (Eds.), Bergey's Manual of Sistematic Bacteriology Volume Three. Springer, New York.

Ramprakash, B., Muthukumar, K., 2014. Comparative study on the production of biohydrogen from rice mill wastewater. Int. J. Hydrogen Energy 39, 14613-14621. doi:10.1016/j.ijhydene.2014.06.029

Rasmussen, H., Sørensen, H.R., Meyer, A.S., 2014. Formation of degradation compounds from lignocellulosic biomass in the biorefinery: Sugar reaction mechanisms. Carbohydr. Res. 385, 45-57. doi:10.1016/j.carres.2013.08.029

Ratti, R.P., Botta, L.S., Sakamoto, I.K., Silva, E.L., Varesche, M.B.A., 2014. Production of $\mathrm{H} 2$ from cellulose by rumen microorganisms: Effects of inocula pre-treatment and enzymatic hydrolysis. Biotechnol. Lett. 36, 537-546. doi:10.1007/s10529-013-1395$\mathrm{Z}$ 
Ratti, R.P., Botta, L.S., Sakamoto, I.K., Varesche, M.B.A., 2013. Microbial diversity of hydrogen-producing bacteria in batch reactors fed with cellulose using leachate as inoculum. Int. J. Hydrogen Energy 38, 9707-9717. doi:10.1016/j.ijhydene.2013.05.089

Ratti, R.P., Delforno, T.P., Okada, D.Y., Varesche, M.B.A., 2015a. Bacterial communities in thermophilic H2-producing reactors investigated using 16S rRNA 454 pyrosequencing. Microbiol. Res. 173, 10-17. doi:10.1016/j.micres.2015.01.010

Ratti, R.P., Delforno, T.P., Sakamoto, I.K., Varesche, M.B.A., 2015b. Thermophilic hydrogen production from sugarcane bagasse pretreated by steam explosion and alkaline delignification. Int. J. Hydrogen Energy 40, 6296-6306. doi:10.1016/j.ijhydene.2015.03.067

Ren, N.Q., Xu, J.F., Gao, L.F., Xin, L., Qiu, J., Su, D.X., 2010. Fermentative biohydrogen production from cellulose by cow dung compost enriched cultures. Int. J. Hydrogen Energy 35, 2742-2746. doi:10.1016/j.ijhydene.2009.04.057

Ren, N.Q., Zhao, L., Chen, C., Guo, W.Q., Cao, G.L., 2016. A review on bioconversion of lignocellulosic biomass to $\mathrm{H} 2$ : Key challenges and new insights. Bioresour. Technol. 215, 92-99. doi:10.1016/j.biortech.2016.03.124

Ren, Z., Ward, T.E., Logan, B.E., Regan, J.M., 2007. Characterization of the cellulolytic and hydrogen-producing activities of six mesophilic Clostridium species. J. Appl. Microbiol. 103, 2258-2266. doi:10.1111/j.1365-2672.2007.03477.x

Saady, N.M.C., 2013. Homoacetogenesis during hydrogen production by mixed cultures dark fermentation: Unresolved challenge. Int. J. Hydrogen Energy 38, 13172-13191. doi:10.1016/j.ijhydene.2013.07.122

Saini, J.K., Saini, R., Tewari, L., 2015. Lignocellulosic agriculture wastes as biomass feedstocks for second-generation bioethanol production: concepts and recent developments. 3 Biotech 5, 337-353. doi:10.1007/s13205-014-0246-5

Saratale, G.D., Chen, S. Der, Lo, Y.C., Saratale, R.G., Chang, J.S., 2008. Outlook of biohydrogen production from lignocellulosic feedstock using dark fermentation - A review. J. Sci. Ind. Res. (India). 67, 962-979.

Saripan, A.F., Reungsang, A., 2014. Simultaneous saccharification and fermentation of cellulose for bio-hydrogen production by anaerobic mixed cultures in elephant dung. Int. J. Hydrogen Energy 39, 9028-9035. doi:10.1016/j.ijhydene.2014.04.066

Sauer, M., Porro, D., Mattanovich, D., Branduardi, P., 2008. Microbial production of organic acids: expanding the markets. Trends Biotechnol. 26, 100-108. doi:10.1016/j.tibtech.2007.11.006

Scheutz, F., Strockbine, N.A., 2005. Genus Escherichia, in: Brenner, D.J., Krieg, N.R., Staley, J.T. (Eds.), Bergey's Manual of Sistematic Bacteriology Volume Two. New York. 
Schleifer, K.-H., 2010. Phylum Firmicutes, in: De Vos, P., Garrity, G.M., Jones, D., Krieg, N.R., Ludwig, W., Rainey, F.A., Schleifer, K.-H., Whitman, W.B. (Eds.), Bergey's Manual of Sistematic Bacteriology Volume Three. Springer, New York.

Shanmugam, S.R., Chaganti, S.R., Lalman, J.A., Heath, D.D., 2014. Statistical optimization of conditions for minimum $\mathrm{H} 2$ consumption in mixed anaerobic cultures: Effect on homoacetogenesis and methanogenesis. Int. J. Hydrogen Energy 39, 15433-15445. doi:10.1016/j.ijhydene.2014.07.143

Shin, J.H., Hyun Yoon, J., Eun Kyoung Ahn, Kim, M.S., Jun Sim, S., Park, T.H., 2007. Fermentative hydrogen production by the newly isolated Enterobacter asburiae SNU-1. Int. J. Hydrogen Energy 32, 192-199. doi:10.1016/j.ijhydene.2006.08.013

Singh, S., Sudhakaran, A.K., Sarma, P.M., Subudhi, S., Mandal, A.K., Gandham, G., Lal, B., 2010. Dark fermentative biohydrogen production by mesophilic bacterial consortia isolated from riverbed sediments. Int. J. Hydrogen Energy 35, 1064510652. doi:10.1016/j.ijhydene.2010.03.010

Skonieczny, M.T., Yargeau, V., 2009. Biohydrogen production from wastewater by Clostridium beijerinckii: Effect of $\mathrm{pH}$ and substrate concentration. Int. J. Hydrogen Energy 34, 3288-3294. doi:10.1016/j.ijhydene.2009.01.044

Sluiter, A., Hames, B., Ruiz, R., Scarlata, C., Sluiter, J., Templeton, D., 2006. Determination of Sugars, Byproducts, and Degradation Products in Liquid Fraction Process Samples Laboratory Analytical Procedure ( LAP ) Issue Date : 12 / 08 / 2006 Determination of Sugars , Byproducts , and Degradation Products in Liquid Fraction Proce. Lab. Anal. Proced. NREL/TP-510-42623 1-14.

Soares, L.A., 2017. Bioconversão anaeróbia do bagaço de cana-de-açúcar em produtos de valor biotecnológico em condição termofílica e mesofílica. Tese (Doutorado). Escola de Engenharia de São Carlos,Universidade de São Paulo.

Soares, L.A., Braga, J.K., Motteran, F., Sakamoto, I.K., Silva, E.L., Varesche, M.B.A., Engineering, S., 2017. Design and optimization of hydrogen production from sugarcane bagasse hydrothermally pretreated using response surface methodology 111. doi:10.2166/wst.2017.183

Song, H., Lee, S.Y., 2006. Production of succinic acid by bacterial fermentation. Enzyme Microb. Technol. 39, 352-361. doi:10.1016/j.enzmictec.2005.11.043

Song, Y., Liu, C., Finegolg, S.M., 2010. Genus I. Bacteroides, in: Krieg, N.R., Staley, J.T., Brown, D.R., Hedlund, B.P., Paster, B.J., Ward, N.L., Ludwig, W., Whitman, W.B. (Eds.), Bergey's Manual of Sistematic Bacteriology Volume Four. Springer, New York.

Szczodrak, J., Fiedurek, J.A.N., 1996. Technology for conversion of lignocellulosic biomass to ethanol. Biomass and Bioenergy 10, 367-375.

Talia, P., Sede, S.M., Campos, E., Rorig, M., Principi, D., Tosto, D., Hopp, H.E., Grasso, D., Cataldi, A., 2012. Biodiversity characterization of cellulolytic bacteria present on 
native Chaco soil by comparison of ribosomal RNA genes. Res. Microbiol. 163, 221-232. doi:10.1016/j.resmic.2011.12.001

Thomsen, M.H., Thygesen, A., Thomsen, A.B., 2008. Hydrothermal treatment of wheat straw at pilot plant scale using a three-step reactor system aiming at high hemicellulose recovery, high cellulose digestibility and low lignin hydrolysis. Bioresour. Technol. 99, 4221-4228. doi:10.1016/j.biortech.2007.08.054

Tsapekos, P., Kougias, P.G., Vasileiou, S.A., Treu, L., Campanaro, S., Lyberatos, G., Angelidaki, I., 2017. Bioaugmentation with hydrolytic microbes to improve the anaerobic biodegradability of lignocellulosic agricultural residues. Bioresour. Technol. 234, 350-359. doi:10.1016/j.biortech.2017.03.043

UNICA, S.P.S.A., 2017. Report of sugarcane cultivated area [WWW Document]. URL http://www.unicadata.com.br/historico-de-producao-e-moagem (accessed 3.7.17).

Valdez-Vazquez, I., Poggi-Varaldo, H.M., 2009. Hydrogen production by fermentative consortia. Renew. Sustain. Energy Rev. 13, 1000-1013. doi:10.1016/j.rser.2008.03.003

Valdez-Vazquez, I., Ríos-Leal, E., Esparza-García, F., Cecchi, F., Poggi-Varaldo, H.M., 2005a. Semi-continuous solid substrate anaerobic reactors for $\mathrm{H} 2$ production from organic waste: Mesophilic versus thermophilic regime. Int. J. Hydrogen Energy 30, 1383-1391. doi:10.1016/j.ijhydene.2004.09.016

Valdez-Vazquez, I., Sparling, R., Risbey, D., Rinderknecht-Seijas, N., Poggi-Varaldo, H.M., 2005b. Hydrogen generation via anaerobic fermentation of paper mill wastes. Bioresour. Technol. 96, 1907-1913. doi:10.1016/j.biortech.2005.01.036

Wang, A., Ren, W., Shi, Y., Lee, D.J., 2008. Bioaugmented hydrogen production from microcrystalline cellulose using co-culture-Clostridium acetobutylicum X9X9 and Ethanoigenens harbinense B49B49. Int. J. Hydrogen Energy 33, 912-917. doi:10.1016/j.ijhydene.2007.10.017

Wang, C.C., Chang, C.W., Chu, C.P., Lee, D.J., Chang, B. V., Liao, C.S., 2003. Producing hydrogen from wastewater sludge by Clostridium bifermentans. J. Biotechnol. 102, 83-92. doi:10.1016/S0168-1656(03)00007-5

Wang, J., Wan, W., 2009. Factors influencing fermentative hydrogen production: A review. Int. J. Hydrogen Energy 34, 799-811. doi:10.1016/j.ijhydene.2008.11.015

Wang, Q., Kuninobu, M., Ogawa, H.I., Kato, Y., 1999. Degradation of volatile fatty acids in highly efficient anaerobic digestion. Biomass and Bioenergy 16, 407-416. doi:10.1016/S0961-9534(99)00016-1

Wang, W., Xie, L., Luo, G., Zhou, Q., 2013. Enhanced fermentative hydrogen production from cassava stillage by co-digestion: The effects of different co-substrates. Int. J. Hydrogen Energy 38, 6980-6988. doi:10.1016/j.ijhydene.2013.04.004

Wang, W., Yan, L., Cui, Z., Gao, Y., Wang, Y., Jing, R., 2011. Characterization of a microbial consortium capable of degrading lignocellulose. Bioresour. Technol. 102, 
9321-9324. doi:10.1016/j.biortech.2011.07.065

Werpy, T., Petersen, G., 2004. Top Value Added Chemicals from Biomass Volume I Results of Screening for Potential Candidates from Sugars and Synthesis Gas Top Value Added Chemicals From Biomass Volume I: Results of Screening for Potential Candidates, Pacific Northwest National Laboratory (PNNL) National Renewable Energy Laboratory (NREL). doi:10.2172/15008859

WHO, 2016. Worrld health statistics - Monitoring health for the SDGs. World Heal. Organ. 1.121. doi:10.1017/CBO9781107415324.004

Wilson, D.B., 2011. Microbial diversity of cellulose hydrolysis. Curr. Opin. Microbiol. 14, 259-263. doi:10.1016/j.mib.2011.04.004

Wilson, D.B., 2009. Cellulases and biofuels. Curr. Opin. Biotechnol. 20, 295-299. doi:10.1016/j.copbio.2009.05.007

Wirth, R., Kovács, E., Maróti, G., Bagi, Z., Rákhely, G., Kovács, K.L., 2012. Characterization of a biogas-producing microbial community by short-read next generation DNA sequencing. Biotechnol. Biofuels 5, 41. doi:10.1186/1754-6834-541

Wong, Y.M., Wu, T.Y., Juan, J.C., 2014. A review of sustainable hydrogen production using seed sludge via dark fermentation. Renew. Sustain. Energy Rev. doi:10.1016/j.rser.2014.03.008

Wongwilaiwalin, S., Rattanachomsri, U., Laothanachareon, T., Eurwilaichitr, L., Igarashi, Y., Champreda, V., 2010. Analysis of a thermophilic lignocellulose degrading microbial consortium and multi-species lignocellulolytic enzyme system. Enzyme Microb. Technol. 47, 283-290. doi:10.1016/j.enzmictec.2010.07.013

Wu, C.W., Whang, L.M., Cheng, H.H., Chan, K.C., 2012. Fermentative biohydrogen production from lactate and acetate. Bioresour. Technol. 113, 30-36. doi:10.1016/j.biortech.2011.12.130

Xu, J., Thomsen, M.H., Thomsen, A.B., 2010. Feasibility of hydrothermal pretreatment on maize silage for bioethanol production. Appl. Biochem. Biotechnol. 162, 33-42. doi:10.1007/s12010-009-8706-9

Yang, P., Zhang, R., McGarvey, J.A., Benemann, J.R., 2007. Biohydrogen production from cheese processing wastewater by anaerobic fermentation using mixed microbial communities. Int. J. Hydrogen Energy 32, 4761-4771. doi:10.1016/j.ijhydene.2007.07.038

Yokoi, H., Ohkawara, T., Hirose, J., Hayashi, S., Takasaki, Y., 1995. Characteristics of hydrogen production by aciduric Enterobacter aerogenes strain HO-39. J. Ferment. Bioeng. 80, 571-574. doi:10.1016/0922-338X(96)87733-6

Yokoi, H., Saitsu, A., Uchida, H., Hirose, J., Hayashi, S., Takasaki, Y., 2001. Microbial hydrogen production from sweet potato starch residue. J. Biosci. Bioeng. 91, 58-63. doi:10.1016/S1389-1723(01)80112-2 
Yokoi, H., Tokushige, T., Hirose, J., Hayashi, S., Takasaki, Y., 1998. H2 production from starch by a mixed culture of Clostridium butyricum and Enterobacter aerogenes. Biotechnol. Lett. 20, 143-147. doi:10.1023/A:1005372323248

Zhang, C., Yang, H., Yang, F., Ma, Y., 2009. Current Progress on Butyric Acid Production by Fermentation. Curr. Microbiol. 59, 656-663. doi:10.1007/s00284009-9491-y

Zhang, J.N., Li, Y.H., Zheng, H.Q., Fan, Y.T., Hou, H.W., 2015. Direct degradation of cellulosic biomass to bio-hydrogen from a newly isolated strain Clostridium sartagoforme FZ11. Bioresour. Technol. 192, 60-67. doi:10.1016/j.biortech.2015.05.034

Zhang, K., Ren, N.Q., Wang, A.J., 2015. Fermentative hydrogen production from corn stover hydrolyzate by two typical seed sludges: Effect of temperature. Int. J. Hydrogen Energy 40, 3838-3848. doi:10.1016/j.ijhydene.2015.01.120

Zhang, S., Kim, T.H., Lee, Y., Hwang, S.J., 2012. Effects of VFAs concentration on biohydrogen production with clostridium bifermentans 3AT-ma. Energy Procedia 14, 518-523. doi:10.1016/j.egypro.2011.12.968

Zhang, T., Liu, H., Fang, H.H.P., 2003. Biohydrogen production from starch in wastewater under thermophilic condition. J. Environ. Manage. 69, 149-156. doi:10.1016/S0301-4797(03)00141-5

Zhang, Y.H.P., Lynd, L.R., 2004. Toward an aggregated understanding of enzymatic hydrolysis of cellulose: Noncomplexed cellulase systems. Biotechnol. Bioeng. 88, 797-824. doi:10.1002/bit.20282

Zwietering, M.H., Jongenburger, L., Rombouts, F.M., Van't, R.K., 1990. Modeling of the bacterial growth curve. Appl. Environ. Microbiol. 56, 1875-1881. 